\title{
RATES AND STYLES OF LATE QUATERNARY DEFORMATION ON THE WAIRARAPA FAULT, NORTH ISLAND, NEW ZEALAND
}

\section{Rachel C. Carne}

\author{
A thesis submitted to \\ Victoria University of Wellington \\ in partial fulfilment of the requirements for the degree of \\ Master of Science \\ in Geology \\ School of Geography, Environment and Earth Sciences \\ Victoria University of Wellington \\ 2009
}




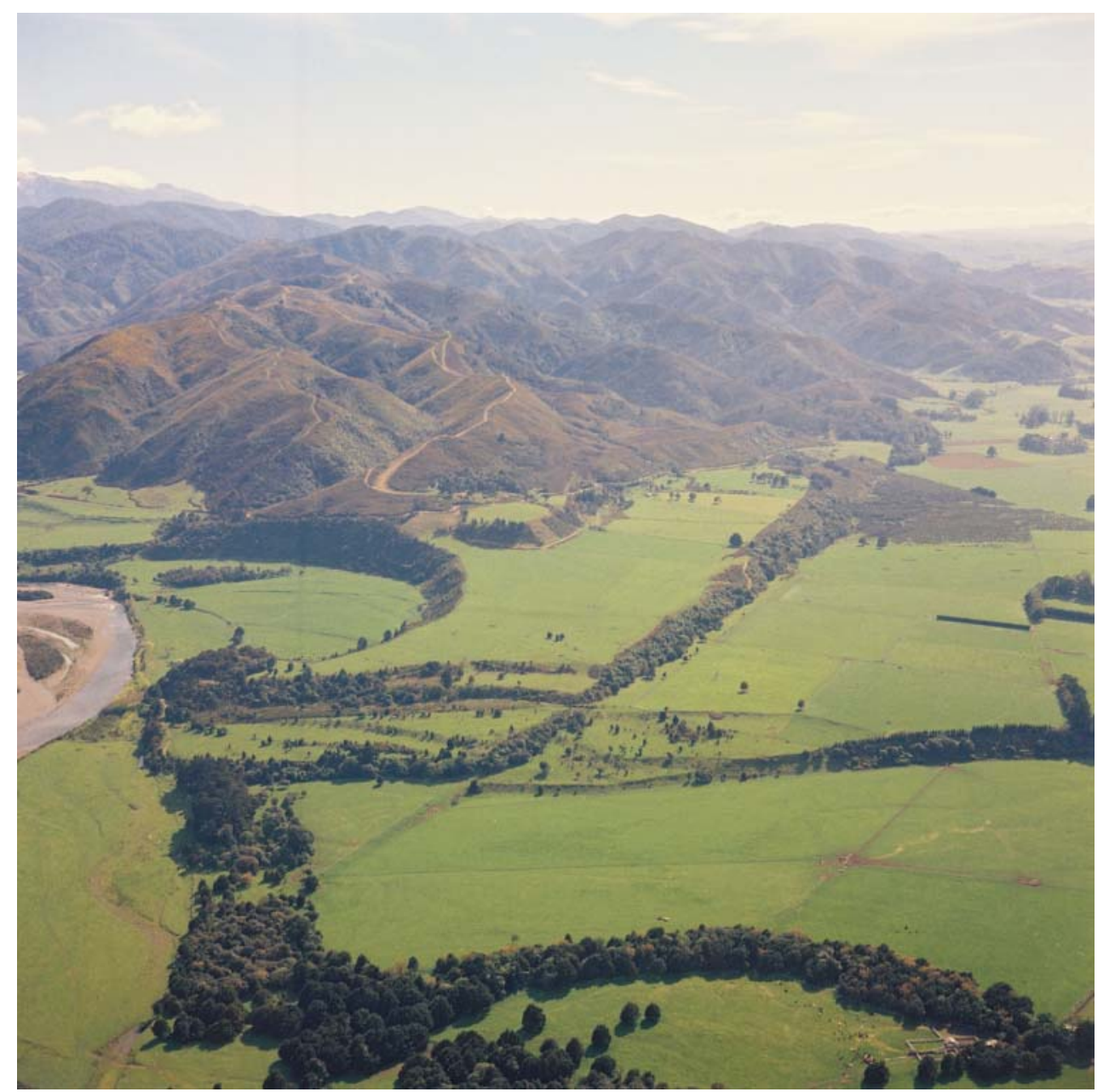

Frontispiece: The Wairarapa Fault and displaced Waiohine terraces, looking north from Waiohine River. Aerial photograph taken by D. L. Homer of GNS Science in 1986 
The Wairarapa Fault is a major active dextral strike-slip fault in the southern North Island of New Zealand. It is expressed at the surface as a highly segmented fault trace that occurs $\sim 100-400 \mathrm{~m}$ east of the Tararua and Rimutaka Range front, where it cuts Last Glacial Maximum (LGM) aggradation gravels. Along its central section, northeast of the Waiohine River, the Wairarapa Fault progressively displaces a flight of post-LGM degradation terraces incised into the "Waiohine" surface at the top of these gravels. Detailed mapping of the variably displaced fluvial terraces at Waiohine River using a Real-Time Kinematic (RTK) Global Positioning System (GPS) and an Electronic Distance Meter (EDM) was used to produce Digital Elevation Models (DEM) from which, the displacements of terraces, risers and paleochannels could be quantified. The timing of fluvial terrace abandonment by the Waiohine River was constrained from previously published and newly obtained Optically Stimulated Luminescence (OSL) dating of post-abandonment sands and silts that mantle the Waiohine terraces. The cumulative dextral displacements of terrace risers range from $12.4 \pm 0.8 \mathrm{~m}(2 \sigma)$ for the youngest terrace, to $101.1 \pm 3.4 \mathrm{~m}(2 \sigma)$ for the oldest terrace (this is the Waiohine aggradation surface). The corresponding cumulative vertical displacements of the treads of these terraces range from 1.3 $\pm 0.02 \mathrm{~m}(2 \sigma)$ to $19.7 \pm 0.09 \mathrm{~m}(2 \sigma)$. The ratio of horizontal to vertical slip for the seven Waiohine terraces averages $6.9 \pm 3.5(2 \sigma)$.

A comparison between the paleochannel and adjacent riser displacements at the Waiohine terraces suggests that a complete riser trimming model for progressive fault displacements of flights of degradation terraces is most appropriate at this site. Under a complete trimming model, a riser begins recording displacement only after its lower bounding terrace tread is abandoned. We estimate the Late Quaternary dextral slip rate for the central part of the Wairarapa Fault by measuring the lateral offsets and abandonment ages of two terrace-riser pairs. Based on previously published OSL age data, and our new estimated displacement for the Waiohine aggradation surface, we calculate a dextral slip rate of $12.0 \pm 3.5 \mathrm{~mm} / \mathrm{yr}(1 \sigma)$ for the central Wairarapa Fault. The dextral displacement and maximum OSL age determined in this study for the next younger terrace require a minimum dextral slip rate of $7.2 \pm 0.8 \mathrm{~mm} / \mathrm{yr}(1 \sigma)$. We also determine the magnitudes of the inferred 1855 (smallest displacement) and penultimate (next-smallest displacement) single-event displacements at Waiohine terraces, as $12.4 \pm 0.8 \mathrm{~m}(2 \sigma)$ and $9.7 \pm 1.7 \mathrm{~m}(2 \sigma)$, respectively, implying a mean co-seismic dextral displacement of $10.6 \pm 2.6 \mathrm{~m}(2 \sigma)$ at the Waiohine River for the last two earthquakes on the Wairarapa Fault. Previous studies suggest a northward decrease in slip rate, but are inconclusive as to the mechanism by which this decrease is accommodated. By comparing our slip rate and single-event displacement data with results from elsewhere along the fault, we infer that there has been a northward decrease in both long-term dextral slip rate and the mean size of co-seismic dextral displacements. Co-seismic dextral displacements are 10-30\% lower at Waiohine River than on the southern Wairarapa Fault (alongstrike distance of 15-20 km), and 10-50\% lower on the northern section of the fault near Mauriceville than at Waiohine River (along-strike distance of $\sim 35 \mathrm{~km}$ ). The decrease in Late Quaternary dextral slip rate northwards along the fault is therefore, probably a longer-term expression of such an along-strike reduction in the mean size of co-seismic strike-slip on Wairarapa Fault ruptures. This reduction may have been caused by a slip transfer off of the main fault and onto some combination of the Carterton, Masterton and Mokonui Faults, that splay northeast-ward off of that fault. 
The surface trace of the central section of the Wairarapa Fault is characterised by a series of left-stepping en echelon fault segments, where deformational pressure bulges have formed in the area of overlap between adjacent discontinuous strands. We mapped the fault and associated deformational surface features through a combination of field mapping and aerial photograph surveys. In addition, we used an RTK GPS to collect detailed topographic data across two particularly well defined pressure bulges, just south of the Waiohine River. Using this quantitative topographic data, we calculated the volumes of these two bulges, and the depths at which the faults bounding these bulges converge into a single fault plane. The near-surface 3D geometry of the Wairarapa Fault is defined by a three-order hierarchy of faults, where the lower two orders of faults are arranged in an en echelon array with respect to the next higher order fault. We define the first-order fault to be the single, northwest-dipping Wairarapa Fault plane that we infer to exist at depth within basement rock. The second-order (Type A) fault segments are defined to be $2-7 \mathrm{~km}$ long and separated by stepover widths of 250-350 m. These stepovers are where the largest (Type A) bulges have formed. Our volumetrically calculated fault convergence depth for Type A bulges are $\sim 100-260 \mathrm{~m}$, suggesting that Type A faults converge into a single Wairarapa Fault plane within basement rock, and well below the LGM Waiohine gravels. We infer that the Type A faults and bulges began forming within basement rock prior to Waiohine gravel deposition. The distinctly smaller, third-order (Type B) fault segments are 500-4000 $\mathrm{m}$ long and separated by fault stepover widths of 30-150 m. Between these segments, the smaller (Type B) bulges have formed. Our volumetrically calculated fault convergence depths for Type B faults are $\sim 1-18 \mathrm{~m}$, suggesting that the bulges bounding faults converge downwards at or near the base of the Waiohine gravels. The Type B bulges, therefore appear to have formed by distributed deformation of the near-surface Waiohine gravels after they had buried the pre-existing Wairarapa Fault plane in basement.

The currently active Wairarapa Fault, located 100-400 m east of the range-front, we infer to be a relatively immature splay that has recently propagated upward through previously unfaulted material from an older Wairarapa Fault at depth, reflecting eastward propagation of deformation into the Wairarapa Valley in response to topographic loading of the Tararua and Rimutaka Ranges. The segmented, discontinuous characteristics of its surface fault zone suggest that the current fault strand is at an early stage of its evolution even at depth in basement, an apparent immaturity that is not simply restricted to the deformation of the surficial Waiohine gravels (e.g. Type B bulges). By reference to the results of previously published analogue models and up-scaling of these results to the dimensions of the natural setting, we qualitatively estimate a finite dextral displacement on the currently active strand of the Wairarapa Fault of between $\sim 130 \mathrm{~m}$ and $\sim 1700 \mathrm{~m}$. Together with our new Late Quaternary dextral slip rate estimate for the central Wairarapa Fault, this would seem to imply an age of inception the currently active splay of the Wairarapa Fault in the Wairarapa Valley of perhaps 100-250 ka or younger.

In the natural case of the Wairarapa Fault, en echelon fault segments ("R-faults") strike only $2^{\circ}-18^{\circ}$ (average of $\sim 6-7^{\circ}$ ) with respect to the average strike of the main fault in basement. This angle is much smaller than is modelled in analogue experiments of the deformation of a previously unfaulted overburden above a strikeslip to slightly oblique-slip basement fault $\left(10^{\circ}-30^{\circ}\right)$. The width of the fault zone is also much narrower $(350$ m) for the Wairarapa Fault, than the scaled-up widths of the fault zones produced in these analogue models (1-2 km). These differences are interpreted to reflect the shallow fault convergence depths for the Wairarapa Fault in comparison to those created in the analogue models, which include a thick surficial "overburden" of unfaulted sand. That thick overburden allows the fault at depth to propagate upward as a wide splay-bounded 
fault zone at the surface. The surface structures along the Wairarapa Fault exhibit a strong plan-view asymmetry that is reflected in the consistently triangular shape of Type A and B pressure bulges and the across-strike asymmetry defined by the geometry of the faults and bulges in profile. Moreover, there is a partitioning of oblique slip components between the two different splays bounding a given pressure bulge along the Wairarapa Fault, where the northwest bounding fault strands exhibit a greater proportion of strikeslip displacement, and the southeast bounding faults exhibit a greater proportion of dip-slip displacement. This asymmetry is interpreted to be a result of the obliquity of convergence and the northwest dip of the master Wairarapa Fault plane at depth. 


\section{Acknowledgements}

My greatest thanks go to my supervisor, Tim Little, for his continued guidance, patience, and advice throughout my thesis research. The results of this research have benefited greatly from his knowledge, expertise and critical assessment. I thank him for introducing me to the fascinating fields of paleoseismology and neotectonics.

This research was funded by a New Zealand Earthquake Commission grant, and by two Victoria Science Faculty/SGEES Strategic Research grants. A Victoria Graduate Award and Kathleen Stewart Postgraduate Scholarship aided in covering tuition costs.

Thanks to Russ Van Dissen for his assistance and invaluable experience in the collection and interpretation of paleoseismic data, and to Uwe Rieser and Ningsheng Wang for their careful work in the preparation and processing of OSL samples. Thanks also to Mark Henderson for his technical assistance in the collection and processing of GPS data, Andrew Rae for GIS support, Alan Hogg at the University of Waikato for processing of ${ }^{14} \mathrm{C}$ samples, Pilar Villamor and Gill Ruthven for their support and helpful discussions.

Thank you to the land owners who kindly granted me unlimited access and permission to excavate on their property, in particular, D. Cleal, G. Morgan, and R. Barton.

Numerous field excursions were made more successful and enjoyable, thanks to my enthusiastic field assistants: Dave Murphy, Hannu Seebeck, Dee Ninis, Keely Schreiber, Julia Bull and Dan Bassett.

Thank you to my fellow office mates and good friends, Susanne, Megan and Dee, whose tremendous support over these past few months has meant the world to me. I will always have warm memories of the special times we shared together in CO419. Thanks to the incredible friends I have made during my time at Vic: Dave, Evey, Kim, George, Julse, Boots, Rory, Dan, Ben, among many others, for making this such an awesome journey.

Finally, I would like to thank my family. To Mum, for her unwavering love and support throughout my years at uni, and for always knowing when I needed her most. Thanks to Dad and Roz for their confidence in me and for always having a keen interest in my research, and Daniel, Lana and Braith for their understanding, encouragement and motivation. 
Table of Contents

Frontispiece II

$\begin{array}{lll}\text { Abstract } & \text { III }\end{array}$

$\begin{array}{ll}\text { Acknowledgements } & \text { VI }\end{array}$

Tables of Contents

List of Figures $\quad$ XIV

$\begin{array}{ll}\text { List of Tables } & \text { XVII }\end{array}$

1 Introduction 1

Carne, R. C. $\quad$ VII 
2 Using Displaced River Terraces to determine Late Quaternary Slip Rate for the Central Wairarapa Fault at Waiohine River, New

\section{Zealand}

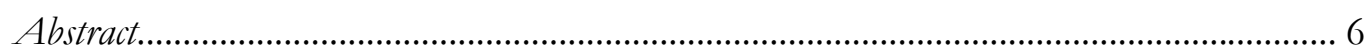

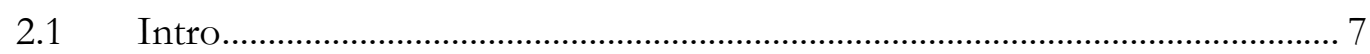

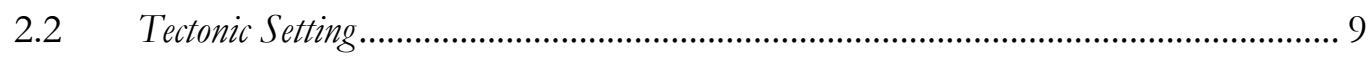

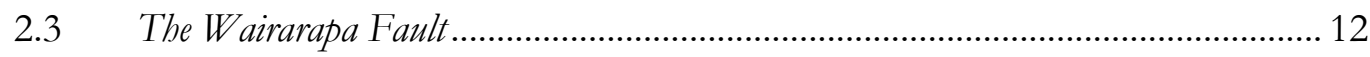

$2.4 \quad$ Geomorphology and Age of the Faulted Waiohine terraces......................................... 14

2.4.1 Previous studies at the Waiohine terraces .......................................... 14

2.4.2 Collection of new displacement and age data at the Waiohine terraces .................................................................................. 14

2.4.3 Displacement of the Waiohine surface ……………………………...... 16

2.5 Previous Models for Progressive Fault Displacement of Flights of

Degradational Terraces.

2.6 Method for Determining Horizontal and Vertical Displacements of Terraces

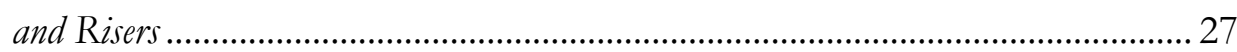

2.7 Displacement Estimates for the Waiohine Terraces ................................................. 30

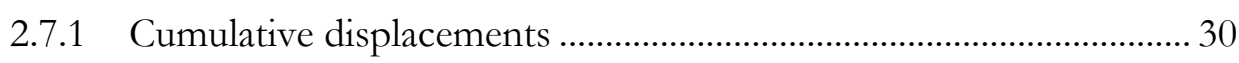

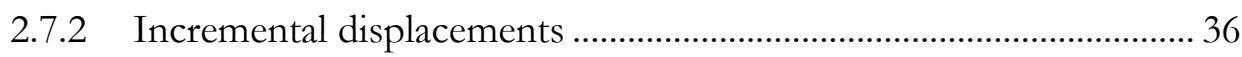

$2.8 \quad$ Terrace Ages at W aiobine River................................................................................ 38

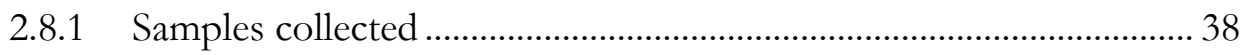

2.8.2 Optically Stimulated Luminescence (OSL) dating technique ............ 39

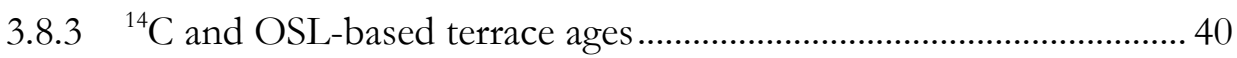

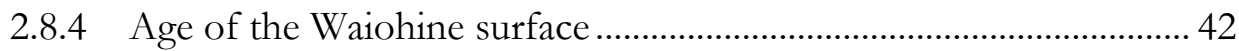

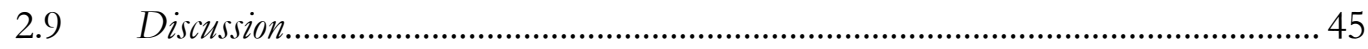

2.9.1 Interpreting progressive fault displacements at

Waiohine River terraces under a complete riser trimming model... 45

2.9.2 Single-event displacements on the central Wairarapa Fault at the Waiohine River ......................................................................... 45

2.9.3 Horizontal to vertical slip ratios for the central Wairarapa Fault at the Waiohine River ........................................................................ 46

2.9.4 Late Quaternary slip rate for the central Wairarapa Fault at the Waiohine River ......................................................................... 48

2.9.5 Variation in single-event dextral displacements on the

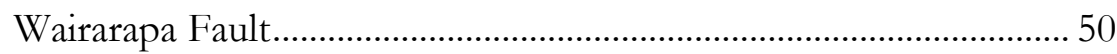


2.9.6 Variation in Late Quaternary dextral slip rate on the Wairarapa Fault.. .51

2.9.7 Accommodating northward-decreasing single-event displacements and slip rates on Wairarapa Fault................................. 53

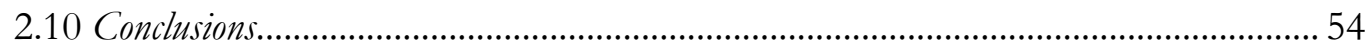


3 Development of Deformational Bulges along the Active StrikeSlip Wairarapa Fault, New Zealand

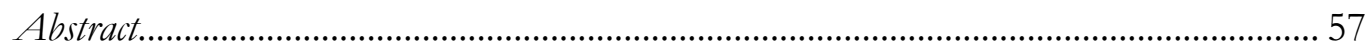

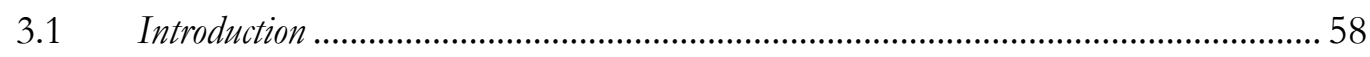

3.2 Tectonic Setting and the Wairarapa Fault .............................................................. 59

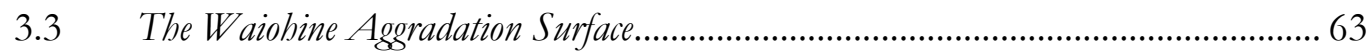

3.4 Formation of En Echelon Faults and Deformational Bulges along

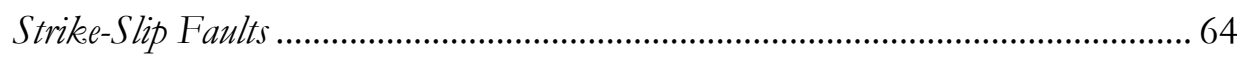

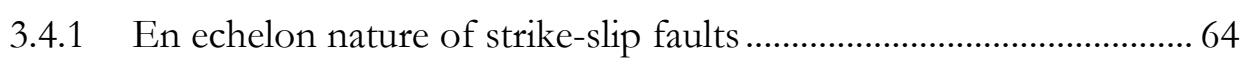

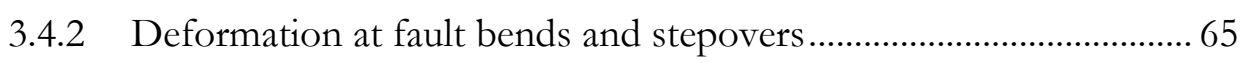

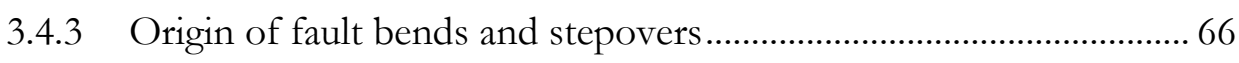

3.5 New Fault Mapping on the Central Section of the Wairarapa Fault .......................... 68

3.5.1 Collection of new surface map and RTK GPS data along

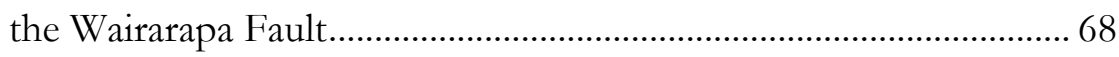

3.5.2 Segmented geometry of the Wairarapa Fault trace and its bulges

3.5.3 Comparison of segmentation pattern with other strike-slip faults in New Zealand. .73

3.6 Analogue Models of Strike-Slip Deformation ........................................................ 74

3.6.1 Summary of four main categories of analogue models ..................... 74

3.6.2 Effects of boundary conditions on analogue models of strike-slip fault zones .................................................................... 78

3.7 Deformational Bulges along the Wairarapa Fault................................................. 80

3.7.1 Classification of bulge types and their characteristics ........................... 80

3.7.2 Volume calculations and fault convergence depths for two bulges along the Wairarapa Fault ................................................. 85

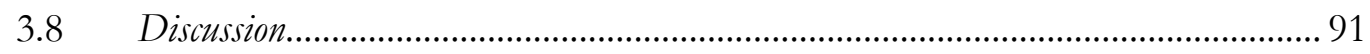

3.8.1 Upward propagation of a young Wairarapa Fault into the

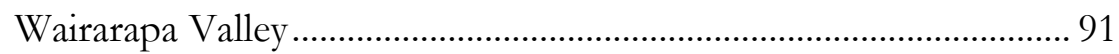

3.8.2 Depth of fault segmentation and deformational bulging along the Wairarapa Fault 94

3.8.3 Finite displacement on the current strand of the Wairarapa Fault 96

3.8.4 A model for the 3D geometry of the Wairarapa Fault. 100 
3.8.5 Asymmetry of deformational surface structures along the Wairarapa Fault................................................................................... 105

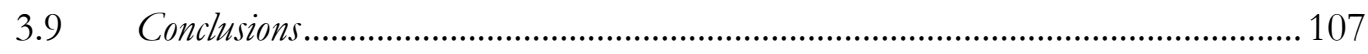


References

Appendices

A Fields Methods, Data Reduction, and Modelling

A1 Real-Time Kinematic Global Positioning System field methods

A2 Real-Time Kinematic Global Positioning System data reduction

A3 Electronic Distance Meter field methods

A4 Electronic Distance Meter data reduction

A5 Producing and contouring Digital Elevation Models

A6 Producing Triangulated Irregular Networks

B Interpretation of Wairarapa Fault Displacements at Waiohine Terraces

B1 Summary of displacements from previous studies at

Waiohine terraces

B2 Differences between our mapped interpretation and those of previous studies at the Waiohine terraces

B3 Summary of displacements from this study at Waiohine Terraces.

B4 Differences between our measured displacements and those of previous studies at the Waiohine terraces

\section{Ages of Waiohine surface and Other Degradation}

C1 OSL \& ${ }^{14} \mathrm{C}$ sample collection at Waiohine terraces

C2 Results of OSL dating of samples from terraces B and $\mathrm{E}$ at Waiohine River.

C3 Interpretation of modern ${ }^{14} \mathrm{C}$ ages of samples from Terrace E at Waiohine River 
C4 Previous age estimates for the Waiohine surface

D Applicability of Analogue Models to Surface

Deformation along the Wairarapa Fault

D1 Applicability of analogue models to surface deformation along the Wairarapa Fault 154

References cited in Appendices 159

\section{Back Pocket:}

Little, T. A., Van Dissen, R., Schermer, E., and Carne, R. 2009. Late Holocene surface ruptures on the southern Wairarapa Fault, New Zealand: Link between oblique-reverse earthquakes and the raising of beach ridges on a rocky coast: Lithosphere, v. 1, no. 1, p. 4-28.

Series of 12 plates at a scale of 1:6,000 of orthorectified aerial photographs overlain with geological interpretation of tectonic structures along central section of Wairarapa Fault, including unpublished map data collected by Rodgers and Little south of Featherston. A plate index map and key are also attached

DVD containing ArcGIS database Wairarapa Fault, orthorectified aerial photographs, Digital Elevation Models, and Shape Files containing compiled geological interpretations and topographic data 


\section{List of Figures}

\section{Using Displaced River Terraces to determine Late Quaternary}

Slip Rate for the Central Wairarapa Fault at Waiohine River, New

\section{Zealand}

1. Major active faults in the lower North Island, New Zealand ........................... 8

2. Overview map of Waiohine River terrace site ..................................................... 11

3. Simplified geomorphology and sample locality map of terrace

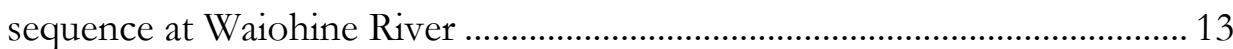

4a-c. Interpretations of Waiohine terraces at Waiohine River ................................. 15

5. Looking for evidence of paleochannels on the Waiohine surface ................ 19

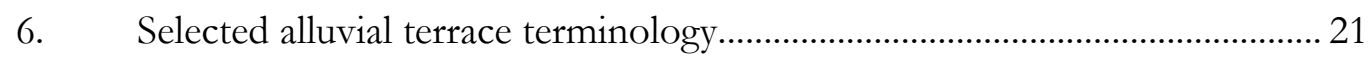

7. Two-stage plan view models of a degradational terrace sequence undergoing the same amount of river downcutting and lateral faulting but different amounts of lateral riser trimming

8. Narrow valley or deeply-incised gorge opening onto alluvial plain across an active strike-slip fault 25

9. Cross sectional models of a river bed and bank undergoing the same amount of vertical faulting but different amounts of river downcutting .25

10. Method of calculating displacements

11a-f. Microtopographic maps of terrace, riser and paleochannel displacements across the Wairarapa Fault.

12. Mean postglacial river incision versus terrace age on the southeast side of the Wairarapa Fault at the Waiohine terraces

13. Cumulative vertical displacement versus cumulative dextral displacement across the Wairarapa Fault at the Waiohine terraces

14. Cumulative dextral and vertical displacements across the Wairarapa Fault versus terrace age for terraces of known age.

15. Variation in dextral slip rate and 1855 and penultimate earthquake dextral displacements along Wairarapa Fault 

Slip Wairarapa Fault, New Zealand

16. Major active faults in the lower North Island, New Zealand 60

17. Calculating the local fault convergence angle at the Wairarapa Fault using a rigid fault displacement model

18. Different types of "secondary" strike-slip faults that may form in the overburden above a single basement pure strike-slip fault

19. Map views of strike-slip fault restraining and releasing bends and stepovers, and the associated deformation.

20. Central Section of the Wairarapa Fault. .70

21. Measurements made at each pressure bulge associated with left stepover on the dextral Wairarapa Fault.

22a-p. Pressure bulges along the Wairarapa Fault from northeast (a) to southwest (p) with overlain fault trace interpretation

23. Relationships between different bulge characteristics for pressure bulges along the Wairarapa Fault.

24. Digital Elevation Models and Triangulated Irregular Networks for two pressure bulges along the Wairarapa Fault near Waiohine River.

25. 3D diagram illustrating the method of pressure bulge volume calculation and estimation of fault convergence depth

26. Schematic interpretation of 3D fault geometry along the Wairarapa Fault

27. Stage of fault evolution as a function of total strike-slip displacement or shearing for different analogue models .98

\section{Appendices}

\section{A Fields methods, data reduction, and modelling}

A1-1. RTK base stations and survey points from the 2008 surveys at the Waiohine terraces

A1-2. RTK base stations and survey points from the 2008 surveys at the large pressure bulge just southwest of Waiohine River

A1-3. RTK base stations and survey points from the 2008 surveys at the small pressure bulge just southwest of larger bulge

A3-1. EDM control points and survey points from the 2007 and 2008 surveys at the Waiohine terraces. 
A4-1. Method of calculating location of secondary EDM control points from GPS-defined location of one control point and local EDM offset to second control point 135

A5-1. Contoured Digital Elevation Model of Waiohine River Terraces 138

C Ages of Waiohine surface and other degradation terraces at Waiohine River

C1-1. Stratigraphic columns and photos showing OSL and

${ }^{14} \mathrm{C}$ samples collected at and near the Waiohine terraces 148 


\section{List of Tables}

2 Using Displaced River Terraces to determine Late Quaternary Slip Rate for the Central Wairarapa Fault at Waiohine River, New

\section{Zealand}

1. Results of OSL and ${ }^{14} \mathrm{C}$ dating of samples from the Waiohine River area .. 17

2. Cumulative and incremental vertical and horizontal displacements, and differences in riser heights and terrace widths across the

Wairarapa Fault

3. Cumulative horizontal and vertical displacement results from this study

compared to results from previous studies at the Waiohine terraces

3 Development of Deformational Bulges along the Active StrikeSlip Wairarapa Fault, New Zealand

4. Characteristics of each pressure bulge along the Wairarapa Fault ................. 72

5. Variables in volume calculations at the two pressure bulges along the Wairarapa Fault to determine fault convergence depths

6. Stage of fault evolution as a function of total strike-slip displacement or shearing for different analogue models.

\section{Appendices}

\section{A Fields methods, data reduction, and modelling}

A2-1. RTK base station location from the 2007 survey at the

Waiohine terraces

A2-2. RTK base stations from the six different 2008 surveys at the

Waiohine terraces

A2-3. RTK base stations from the four different 2008 surveys at the large pressure bulge, southeast of Waiohine River

A2-4. RTK base station for the 2008 survey at the small pressure bulge,

Further southeast of Waiohine River

A4-1. EDM control stations 2007

A4-2. EDM control stations 2008 


\section{B Interpretation of Wairarapa Fault displacements at Waiohine terraces}

B1-1. Previous interpretations of cumulative horizontal and vertical displacements at the Waiohine terraces by Grapes and Wellman (1988) and Lensen and Vella (1971)

B3-1. Vertical displacements and differences in riser heights across the Wairarapa Fault at the Waiohine terraces

B3-2. Horizontal displacements and differences in terrace widths across the Wairarapa Fault at the Waiohine terraces

\section{Ages of Waiohine surface and other degradation terraces at Waiohine River}

C2-1. Radionuclide and water contents ................................................................... 149

C2-2. Measured a-value, equivalent dose, cosmic and total doserate and luminescence age

C4-1. Previous age estimates for the Waiohine surface $151-152$ 


\section{Introduction}

Strike-slip faults in nature commonly exhibit highly segmented surface traces. Deformational bulges are well-documented in the stepover region between strike-slip fault segments, forming in response to local contraction caused by fault slip. Sand and clay analogue models have long been used to better understand the formation of en echelon fault segments in the sedimentary cover above a single basement strike-slip fault (e.g. Cloos, 1929; Naylor et al., 1986; Riedel, 1929; Wilcox et al., 1973). The formation of pressure bulges above bends or stepovers in the strike-slip basement fault has also been a subject of analogue deformation modelling (e.g. McClay \& Bonora, 2001; Richard et al., 1995). Natural occurrences of these discontinuous surface deformational features, however, are typically more complex than can be explained by these simple models. Strike-slip faults in nature almost always accommodate oblique-slip rather than pure strike-slip displacement, however, very few analogue models attempt to explain the surface deformation above a reverse-oblique strike-slip fault (e.g. Richard, 1991; Richard et al., 1995). In obliquely convergent natural settings, the mechanisms controlling the geometry and depth extent of fault segmentation and the development of pressure bulges in the fault stepover region remain poorly understood.

Flights of degradation terraces provide an excellent environment in which to study the interaction of an active fault with a downcutting river, and the rates and directions of fault slip through time. To use displaced terrace risers to measure slip rates on strike slip faults requires knowledge of how those alluvial landforms interact with the river and fault scarp, and when they begin to record fault slip. The age of a terrace riser (the incisional slope between two adjacent terrace surfaces) represents the time at which fluvial lateral erosion of that paleo-river bank ended. Temporally, this must have taken place some time between the abandonment ages of the upper and lower terrace treads bounding that riser. However, the exact relationship between the timing and magnitude of a terrace riser displacement is commonly uncertain (e.g., Avouac, 1993; Cowgill, 2007; Harkins \& Kirby, 2008; Lensen 1964; Suggate, 1960).

The Wairarapa Fault is one of four major active strike slip faults in the southern part of the North Island Dextral Fault Belt (NIDFB) of New Zealand, and most recently ruptured during an $\mathrm{M}_{\mathrm{w}}>8.1$ earthquake in 1855. The North Island lies on the Australian plate to the west of the Hikurangi margin where the Pacific plate subducts beneath the Australian plate. The NIDFB system has formed in the upper part of the Australian plate, and 
accommodates a large proportion of the margin parallel component of obliquely convergent Pacific plate motion. The Wairarapa Fault is clearly expressed as a highly segmented trace at the surface of the Last Glacial Maximum (LGM) "Waiohine" aggradation gravels, to the east of the Rimutaka and Tararua Range front. A series of deformational bulges have formed in the Waiohine surface at left stepovers in the fault trace, and geomorphic features incised into that surface are vertically and horizontally displaced as a result of slip on the fault that has occurred since the cessation of Waiohine gravel deposition. The tectonic processes resulting in the fault segmentation and deformational bulging along the reverse-oblique strike-slip Wairarapa Fault are presently unknown; as is the depth extent to which this segmentation occurs. The mechanisms controlling the near surface fault geometry have important implications for assessing future seismic hazard in terms of rupture propagation through fault stepovers, as well as providing a more general understanding of the development and evolution of reverseoblique strike-slip faults.

The magnitude and distribution of single-event displacements, and the Late Quaternary dextral slip rate on the Wairarapa Fault are largely uncertain, due to lack of abundant or precise displacement estimates for geomorphic features incised into the Waiohine surface and the age of the Waiohine surface. The Late Quaternary slip rate and the magnitude of single-events displacements on the Wairarapa Fault are also important for evaluating future earthquake hazard. Assessments of along-strike variations in dextral slip rate and singleevent displacements are vital to further our understanding of earthquake rupture propagation and slip accommodation, and the transfer of slip onto eastern splay faults (Carterton, Masterton and Mokonui Faults) during Wairarapa Fault earthquakes. The Late Quaternary dextral slip rate on the Wairarapa fault provides insight into how deformation is accommodated in this obliquely convergent plate boundary setting.

To enhance our understanding of styles and rates of Late Quaternary deformation along the Wairarapa Fault in this transpressional plate boundary setting, a comprehensive study of the tectonic geomorphology and paleoseismology of the fault along its central section was undertaken as part of an MSc degree. This thesis presents the results of our investigations. In addition to an extensive set of appendices and related data files (included on the DVD in the back pocket), it is comprised chiefly of two self-contained chapters that describe the rates of active fault slip, and the surface geomorphology and deformation of the Wairarapa Fault between the Waiohine River and Hinaburn, just south of Cross Creek. Each of the two chapters are intended to be submitted for publication, and consequently 
some of the introductory material is repeated near the beginning of each chapter. I will be the lead author of both these submitted papers, as I undertook the mapping, surveying, sampling and other data collection that is presented in them; processed, analysed and interpreted these data; drafted the figures and tables, and wrote the text and accompanying appendices. The first of these two papers is co-authored by Tim Little, who contributed to field work, offered guidance on methodology, generated stimulating discussions, and provided feedback on drafts, and by Uwe Riser who contributed written summaries of the Optically Stimulated Luminescence (OSL) dating techniques and results for the samples that I collected (section 2.8.2, part of section 2.8.3 and Appendix C2). The second paper is also co-authored by Tim Little who provided supervision, feedback on drafts, and other critical assessment of this research.

In Chapter 2, the first of these two papers, new displacement and terrace age data are presented, including $11 \mathrm{OSL}$ and ${ }^{14} \mathrm{C}$ ages, from a flight of degradation terraces incised into the Waiohine surface on the northern side of the Waiohine River that are variably displaced across the Wairarapa Fault. Using this new data, we explore the nature of the interaction between this flight of degradation terraces and the active Wairarapa Fault, which allows us to accurately assign terrace ages to measured terrace riser displacements. The ratio of horizontal to vertical slip and the Late Quaternary dextral slip rate are derived for this central part of the Wairarapa Fault. We investigate along-strike variations in single-event displacements and Late Quaternary slip rate on the Wairarapa Fault, and consider the role of the Carterton, Masterton and Mokonui splay faults in accommodating these variations.

In Chapter 3, the development of fault segmentation and deformational bulges along the Wairarapa Fault is investigated. Using new fault and surface deformation map data, together with analogue modelling studies of strike-slip and oblique-slip deformation, we investigate the mechanisms that produce the observed patterns of surface deformation along the Wairarapa Fault, and explore the effect of the obliquity of slip on this deformation. A model is presented for the near surface 3D geometry of the Wairarapa Fault, constrained in particular, by fault convergence depths calculated by a detailed volumetric analysis of two pressure bulges just southwest of Waiohine River, and the predictions of analogue modelling studies.

Further investigations undertaken as part of this MSc included a paleoseismic study of the southern section of the Wairarapa Fault, to investigate the timing of earthquakes on the fault over the past $\sim 6000$ years. Attached in the back pocket of this thesis is a copy of the 
paper Late Holocene surface ruptures on the southern Wairarapa fault, New Zealand: Link between earthquakes and the uplifting of beach ridges on a rocky coast published in 2009 in the Geological Society of America's journal Lithosphere, as a result of this research. I am a co-author of this paper, and my contributions undertaken as part of this MSc included: 1) the logging of two paleoseismic trenches across the Wairarapa Fault at Cross Creek, 2) collection and submission of OSL and ${ }^{14} \mathrm{C}$ samples from those trenches, 3) preparation of trench $\log$ figures and unit descriptions for the two trenches (CC-3 \& CC-4), 4) collation and preparation of unit names and descriptions in figures and appendices for all four Cross Creek trenches (Figure 8A \& B, 9A \& B), and 5) significant input into several other figures and data tables (Figure 7C, Tables 1, $2 \& 3$ ).

This thesis is organised around the two papers (Chapters 2 and 3), and a large body of supporting data and descriptions of methodology have been sequestered at the back of the thesis in a series of four Appendices. Appendix A contains descriptions of the methods for topographic data collection, processing and modelling. Appendices A1 and A3 provide detail on the use of Real-Time Kinematic (RTK) Global Positioning System (GPS) and Electronic Distance Meter (EDM) techniques to collect to topographic data points at the Waiohine terraces and two pressure bulges along the Wairarapa Fault. Appendices A2 and A4 describe the methods for processing of RTK GPS and EDM data. The methods and variables used for producing and contouring various Digitial Evelvation Models (DEM's) and Triangulated Irregular Networks (TIN's) for the Waiohine terraces and two pressure bulges are described in Appendices A5 and A6.

Appendix B summarises the displacements and interpretations presented in previous studies (and this one) of the Wairarapa Fault at the Waiohine terraces site. The displacements of terraces, risers and paleochannels determined in two previous studies are summarised in Appendix B1. A description of the differences between our mapped terrace interpretation and those of the two previous studies is provided in Appendix B2. The displacements of terraces, risers and paleochannels determined in this study are presented in Appendix B3. In Appendix B4, an explanation is offered for the differences between the displacements determined in this study and those of previous studies.

Appendix C compiles all published data on the ages of the Waiohine surface and other degradation terraces at Waiohine River. Logs of the OSL and ${ }^{14} \mathrm{C}$ samples collected at the Waiohine terraces are illustrated in Appendix C1. The results of OSL and ${ }^{14} \mathrm{C}$ dating of samples from two terraces at Waiohine River are presented in Appendix C2. In Appendix $\mathrm{C} 3$, an interpretation is made for the modern ${ }^{14} \mathrm{C}$ ages of samples from one of the younger 
terraces at Waiohine River. Previous age estimates for the Waiohine surface are summarised in Appendix C4.

Appendix D compares our observations of surface deformation along the Wairarapa Fault with the previously cited results of analogue models from each of the four main categories described in Section 3.6.1, as a function of different boundary conditions. The likely differences between the boundary conditions of the models and the actual Wairarapa Fault are described, and an assessment is made as to which models may best describe the observed pattern of surface faulting and especially deformational bulging along the fault.

Orthorectified aerial photographs, overlain with my geological interpretation of tectonic structures along the central section of the Wairarapa Fault between Waiohine River and Hinaburn are presented as a series of 12 plates (numbered from northeast to southwest, at a scale of 1:6,000). These are in a pocket at the back of this thesis together with a plate index map and key. My interpretations of surface deformation are combined with unpublished map data collected by Rodgers and Little along the Wairarapa Fault south of Featherston, which have been transcribed and geocoded into an ArcGIS database named Wairarapa Fault. A DVD is attached at the back of this thesis containing the Wairarapa Fault database, from which these plates have been prepared. The DVD contains the orthorectified aerial photographs along the central section of the Wairarapa Fault, and Shape Files containing the compiled map data, including faults (classified into different levels of location uncertainty and different senses of throw), RTK GPS and EDM data and models for the Waiohine terraces and two pressure bulges, rents, displaced risers and streams, swampy areas, landslides, and various topographic map data. 


\title{
2 Using Displaced River Terraces to Determine Late Quaternary Slip Rate for the Central Wairarapa Fault at Waiohine River, New Zealand
}

\begin{abstract}
Northeast of the Waiohine River in central North Island, New Zealand, a flight of terraces are progressively displaced by the dextral-slip Wairarapa Fault. These well-preserved, post-Last Glacial Maximum (LGM) terraces provide an ideal setting in which to study the interaction of an active fault with a flight river terraces. The variably displaced terraces were mapped in detail using a Real-Time Kinematic (RTK) Global Positioning System (GPS) and an Electronic Distance Meter (EDM). Digital Elevation Models (DEM) produced from these data, together with high-resolution aerial photography, allowed us to measure the displacements of 6 terrace surfaces, 5 risers and 2 paleo-channels. We obtain terrace age data by Optically Stimulated Luminescence (OSL) dating of terrace sands and silts at the Waiohine terraces. End-member models of progressive fault displacements of flights of degradation terraces suggest that under different conditions of fault and river interaction, the lateral displacement of a terrace riser can be dated by either the age of the upper bounding terrace, the lower bounding terrace, or somewhere in between. By comparing our observed displacements to those predicted by the models, we show that the complete riser trimming model is appropriate for the Waiohine River terraces. Under this model, a riser begins recording displacement when its lower bounding terrace tread is abandoned. The cumulative dextral displacements of terrace risers range from $12.4 \pm 0.8 \mathrm{~m}(2 \sigma)$ to $101.1 \pm 3.4 \mathrm{~m}(2 \sigma)$, and the cumulative vertical displacements of terrace treads range from $1.3 \pm 0.02 \mathrm{~m}(2 \sigma)$ to $19.7 \pm 0.09 \mathrm{~m}(2 \sigma)$. The ratio of horizontal to vertical slip for the Waiohine terraces ranges from 5.0 to 10.2 , with an average of $6.9 \pm 3.5(2 \sigma)$. We estimate the Late Quaternary dextral slip rate for the central part of the Wairarapa Fault in two ways. Based on previously published OSL age data (Wang \& Grapes, 1991), and our new estimated displacement of the 'Waiohine' aggradation surface, we calculate a dextral slip rate of $12.0 \pm 3.5 \mathrm{~mm} / \mathrm{yr}(1 \sigma)$. Using the dextral displacement and maximum OSL age determined in this study for the next younger terrace, we find a minimum dextral slip rate of $7.2 \pm 0.8 \mathrm{~mm} / \mathrm{yr}(1 \sigma)$. The magnitudes of the inferred 1855 (smallest displacement) and penultimate (next-smallest displacement) singleevent displacements are $12.4 \pm 0.8 \mathrm{~m}(2 \sigma)$ and $9.7 \pm 1.7 \mathrm{~m}(2 \sigma)$, respectively, implying a mean co-seismic dextral displacement of $10.6 \pm 2.6 \mathrm{~m}(2 \sigma)$ at the Waiohine terraces for the last two earthquakes on the Wairarapa Fault. Previous studies suggest a northward decrease in slip rate from the central to northern sections of the Wairarapa Fault however are inconclusive as to the mechanism by which this decrease is accommodated. From an analysis of our data and other results, we find that mean co-seismic dextral displacements for the 1855 and penultimate earthquakes on the Wairarapa Fault decrease by 30 \% from the southern section of the fault near Pigeon Bush to the central section at Waiohine River, and 1855 co-seismic displacements decrease by 10-50\% from the central section to the northern section of the fault near Mauriceville. We suggest that an along-strike reduction in dextral slip during repeated earthquakes may be responsible for the apparent northward decrease in the Late Quaternary dextral slip rate along the fault. Presumably, slip has been transferred onto one or a combination of the Carterton, Masterton and Mokonui Faults during great earthquakes.
\end{abstract}




\subsection{Introduction}

The Wairarapa Fault is a major active dextral strike slip fault in the North Island of New Zealand (Figure 1). It most recently ruptured in an $\mathrm{M}_{\mathrm{w}}>8.1$ earthquake on 23 January 1855, over an onshore distance of $\sim 120 \mathrm{~km}$ (Rodgers \& Little, 2006). Despite this, relatively little is known about the magnitude and distribution of its single-event displacement or its Late Quaternary slip rate. Estimates of 1855 single-event dextral displacements on the Wairarapa Fault range from as high as $\sim 18 \mathrm{~m}$ at Pigeon Bush on the southern part of the fault (Rodgers \& Little, 2006), to as low as 4-7 $\mathrm{m}$ on the Alfredton Fault, discontinuously linked to the northern end of the Wairarapa Fault (Schermer et al., 2004). Estimates of the Late Quaternary dextral slip rate along the central Wairarapa Fault range from $6.5 \mathrm{~mm} / \mathrm{yr}$ (Van Dissen \& Berryman, 1996) to $11.5 \pm 0.5 \mathrm{~mm} / \mathrm{yr}$ (Grapes \& Wellman, 1988; Wang and Grapes, 2007). The uncertainties in slip rate are largely due to uncertainties in the age of the chief geomorphic marker transected by the fault, the widely distributed Last-Glacial-Maximum (LGM) aggradation terrace termed the "Waiohine" surface. Villamor et al., 2008 suggest a northward decrease in Late Quaternary slip rate along the Wairarapa Fault. They suggest two mechanisms by which this may be achieved; a northward dissipation of coseismic slip and/or different sections of the fault rupturing in different earthquakes with more earthquakes on the southern part of the fault.

Flights of fluvial degradation terraces are valuable geomorphic markers of progressive fault displacements on scales of $10^{3}-10^{4}$ years, and can be used to study rates and directions of fault slip through time. To use displaced terrace risers to measure slip rates on strike slip faults requires knowledge of how those alluvial landforms interact with the river and fault scarp, and when they begin to record fault slip. A riser is the incisional slope between two adjacent terrace surfaces. The age of a riser represents the time at which fluvial lateral erosion of that paleo-river bank ended. Temporally, this must have taken place some time between the abandonment ages of the upper and lower terrace treads bounding that riser. However, the exact relationship between the timing and magnitude of a terrace riser displacement is commonly uncertain (e.g., Avouac, 1993; Cowgill, 2007; Harkins \& Kirby, 2008; Lensen 1964; Suggate, 1960). The cessation of lateral erosion of a riser is most commonly assumed to occur closely in time to the abandonment of the lower bounding terrace tread (e.g., Lensen \& Vella, 1971; Little et al., 1998; Mason et al., 2006; Meriaux et al., 2005; 2004; Van der Woerd et al., 2002). Less often, the cessation of lateral erosion of a riser is assumed to occur more closely in time to the initial incision of the upper bounding terrace tread of that riser (e.g., Van Dissen et al., 2005; Zhang et al., 2007 Theoretical 


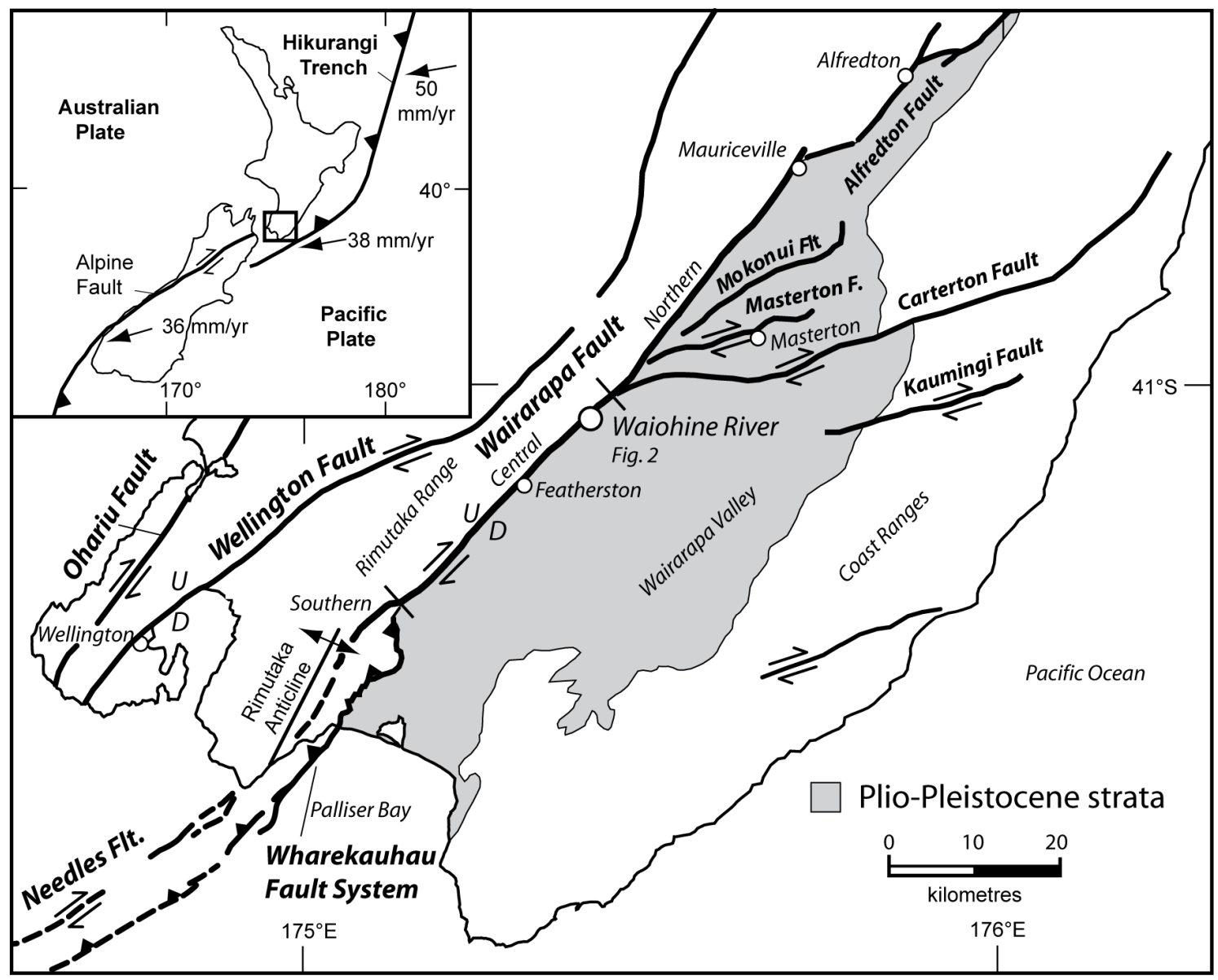

Figure 1. Major active faults in the lower North Island, New Zealand (modified from Little et al., 2009). Small open circles are main towns. Large open circle is area of this study (Waiohine River). Different sections of the Wairarapa Fault referred to in the text are labelled. Inset: Tectonic setting of New Zealand, where Pacific Plate motions are shown relative to a fixed Australian Plate, according to Nuvel-1a plate motion model of De Mets et al., (1990; 1994). 
uncertainty in a riser's age results in uncertainty in a slip rate estimate. Cowgill (2007) illustrates that the minimum and maximum slip rates derived from terrace riser offsets and the ages of the upper and lower bounding terraces respectively, can vary by as little as a factor of 1.2 but commonly vary by a considerably larger factor, as large as a factor of 5 .

In this study we examined a classic flight of terraces to the northeast of the Waiohine River in the central North Island, New Zealand (Figures $2 \& 3$ ) that have been variably displaced by the Wairarapa Fault. The Waiohine terraces were formed by sequential downcutting of the river into older Waiohine aggradation gravels in the Holocene following the Last Glacial Maximum (Lensen \& Vella, 1971). The Waiohine River terraces were an influential locality in the development of ideas about the interaction of an active fault with a flight of degradation terraces (e.g. Lensen, 1964; Lensen \& Vella, 1971). The terrace and riser displacements at the fault scarp are well preserved, providing an exceptional setting in which we can study this interaction, as well as a key site for measuring and dating rates of slip on central section of the Wairarapa Fault.

We quantify displacements of terraces, risers and paleochannels using Digital Elevation Models (DEM's) produced from topographic data points collected using Real-Time Kinematic (RTK) Global Positioning System (GPS) and Electronic Distance Meter (EDM) techniques. We obtain terrace ages through Optically Stimulated Luminescence (OSL) dating of terrace sands and silts. We use this new data to: (1) draw conclusions about the nature of the interaction between flights of degradation terraces and active faults, and determine the most valid model of progressive lateral displacements of flights of degradation terraces at the Waiohine River, allowing us to accurately assign terrace ages to the measured terrace riser displacements, (2) derive the Late Quaternary dextral slip rate and the ratio of horizontal to vertical slip, on a central part of the Wairarapa Fault, and (3) investigate any along-strike variations in single-event displacements and Late Quaternary dextral slip rate on the Wairarapa Fault, and the role of the Carterton, Masterton and Mokonui splay faults in accommodating such variations.

\subsection{Tectonic Setting}

New Zealand straddles the boundary between the Pacific and Australian plates. Oblique subduction of oceanic crust occurs along the northeast trending Hikurangi margin in the North Island, and oblique continental collision takes place in the South Island (Figure 1). 
The southern North Island lies on the Australian plate to the west of the margin (Figure 1). In central New Zealand the relative convergence rate of the Pacific plate relative to the Australian plate is $\sim 39 \mathrm{~mm} / \mathrm{yr}$ along an azimuth of $\sim 261^{\circ}$ (NUVEL-1A of De Mets et al., 1990; 1994).

A small proportion of the margin-perpendicular component of plate motion is accommodated by shortening of the upper (Australian) plate through thrust faulting and related folding in the onshore and offshore parts of the plate, including in an offshore accretionary wedge that merges downwards into the subduction interface (Barnes et al., 1998; Barnes \& Mercier de Lepinay, 1997). A maximum of 3-8 mm/yr of shortening in the upper plate has been reported for the southern North Island since the Oligocene (Nicol et al., 2007), whereas the "lion's share" (>80\%) of the margin-perpendicular motion is inferred to be accommodated by contractional slip on the strongly coupled subduction megathrust (Nicol et al., 2007). Elastic dislocation modelling of GPS data and seismicity in the southernmost North Island, suggests the Hikurangi subduction zone dips gently $\left(9^{\circ}\right)$ westward at $20-25 \mathrm{~km}$ depth beneath Wellington, and that this part of the plate interface is currently locked and accumulating elastic strain, evident from its large slip deficit (Darby \& Beavan, 2001; Reyners, 1998; Wallace et al., 2004; 2008).

The margin-parallel component of plate motion is largely accommodated by dextral slip on the NNE-striking faults of the North Island Dextral Fault Belt (NIDFB) (Beanland, 1995). In the onshore region near Wellington, dextral slip on the Shepards Gulley, Ohariu, Wellington and Wairarapa Faults (Figure 1) accommodate up to $\sim 18 \mathrm{~mm} / \mathrm{yr}$ (Beanland, 1995) of the margin-parallel motion (e.g., Berryman, 1990; Rodgers \& Little, 2006; Van Dissen \& Berryman, 1996; Van Dissen et al., 1992; Wang \& Grapes, 2007). At the surface, these faults typically dip steeply to the northwest, and have a small component of reverseslip. Seismicity data suggest that these faults intersect the subduction megathrust at depths of 20-30 km beneath the southern North Island (e.g., Reyners, 1998). Clockwise verticalaxis rotation of eastern parts of the North Island (e.g., Nicol et al., 2007; Rowen and Roberts, 2008; Wallace et al., 2004), strike-slip on active ENE-striking faults in Cook Strait such as the Boo Boo Fault (e.g., Barnes 2005; Barnes \& Audru, 1999), and oblique slip on NE-trending offshore faults including the subduction megathrust (Barnes and Audru, 1999; Nicol et al., 2007) also accommodate some of the margin-parallel component of plate motion. Deformation of the offshore part of the upper plate above the subduction thrust in the central Hikurangi margin between $40^{\circ} \mathrm{S}$ and $41^{\circ} \mathrm{S}$ could accommodate up to 14-15 $\mathrm{mm} / \mathrm{yr}$ of margin-parallel fault slip (Barnes et al., 1998). 


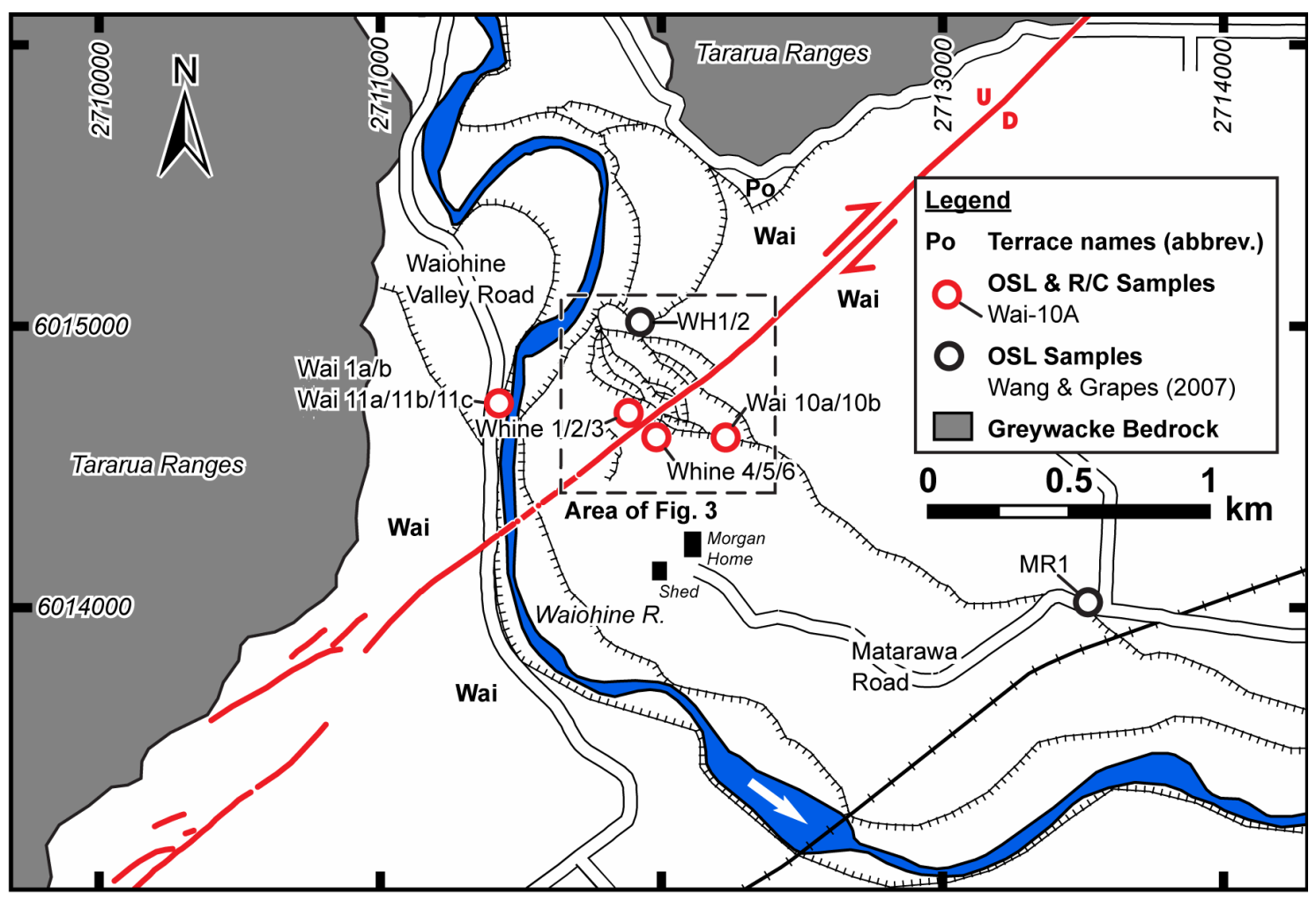

Figure 2. Overview map of Waiohine River terraces. Wairarapa Fault trace is in red. Red circles are locations of new OSL and radiocarbon samples from this study. Black circles are locations of previously published OSL dating results from Wang and Grapes (2007). Unit "Wai" depicts Post- Last Glacial Maximum Waiohine aggradation surface. Coordinates are in New Zealand Map Grid (NZMG). Area of Figure 3 denoted by dashed box. 


\subsection{The Wairarapa Fault}

The Wairarapa Fault is the easternmost dextral-reverse fault in the active NIDFB, bounding the eastern side of the Rimutaka Range (Figure 1). It is interpreted to have been initiated in the Pliocene as a reverse fault, and to have reactivated as a strike-slip fault at 1-2 $\mathrm{Ma}$ in response to a clockwise vertical axis rotation of the forearc relative to the Pacific plate (Beanland, 1995; Beanland \& Haines, 1998; Kelsey et al., 1995). Based on the geometry of its trace, the Wairarapa Fault can be divided into southern, central, and northern sections (Figure 1).

The central section, when observed at scales smaller than 1:250,000, consists of an en echelon array of mostly left-stepping faults. These discontinuous dextral-oblique faults are separated by contractional bulges or folds in the area of their overlap that cause warping of alluvial terrace surfaces (Grapes \& Wellman, 1988; Rodgers \& Little, 2006). Rodgers and Little (2006) mapped 15 individual fault strands $1200 \pm 700 \mathrm{~m}$ long on the southern part of the central Wairarapa Fault, separated by stepovers 400-600 m long and 20-200 m wide. Along its central section, the Wairarapa Fault forms the boundary between the greywacke of the Rimutaka Ranges, and the Holocene and latest Pleistocene river gravels of the Wairarapa Valley (Grapes, 1991).

The northern section of the Wairarapa Fault (north of Waiohine River) bifurcates eastward into a series of east-northeast striking dextral splay faults (Figure 1) including the Carterton, Masterton and Mokonui Faults (Zachariasen et al., 2000). In its northern section, the Wairarapa Fault cuts Miocene-Pliocene sediments, and in places, exhibits an up-to-thenorthwest sense of vertical displacement (Grapes, 1999), due to the faults near-vertical dip in its northern section (Hicks \& Woodward, 1978). The fault is geomorphically well defined as far north as Mauriceville, beyond where it bifurcates into two discontinuously linked, more diffusely expressed, sub-parallel strands of slower slipping faults within Late Miocene mudstone (Grapes, 1991), including the Pa Valley-Makuri Fault system to the west and the Dreyers Rock-Alfredton Fault system to the east (Schermer et al., 2004). The eastern strand includes the Dreyers Rock, Alfredton, Saunders Road and Waipukaka Faults, and the western strand includes the Pa Valley and Makuri Faults (Schermer at al., 2004). 


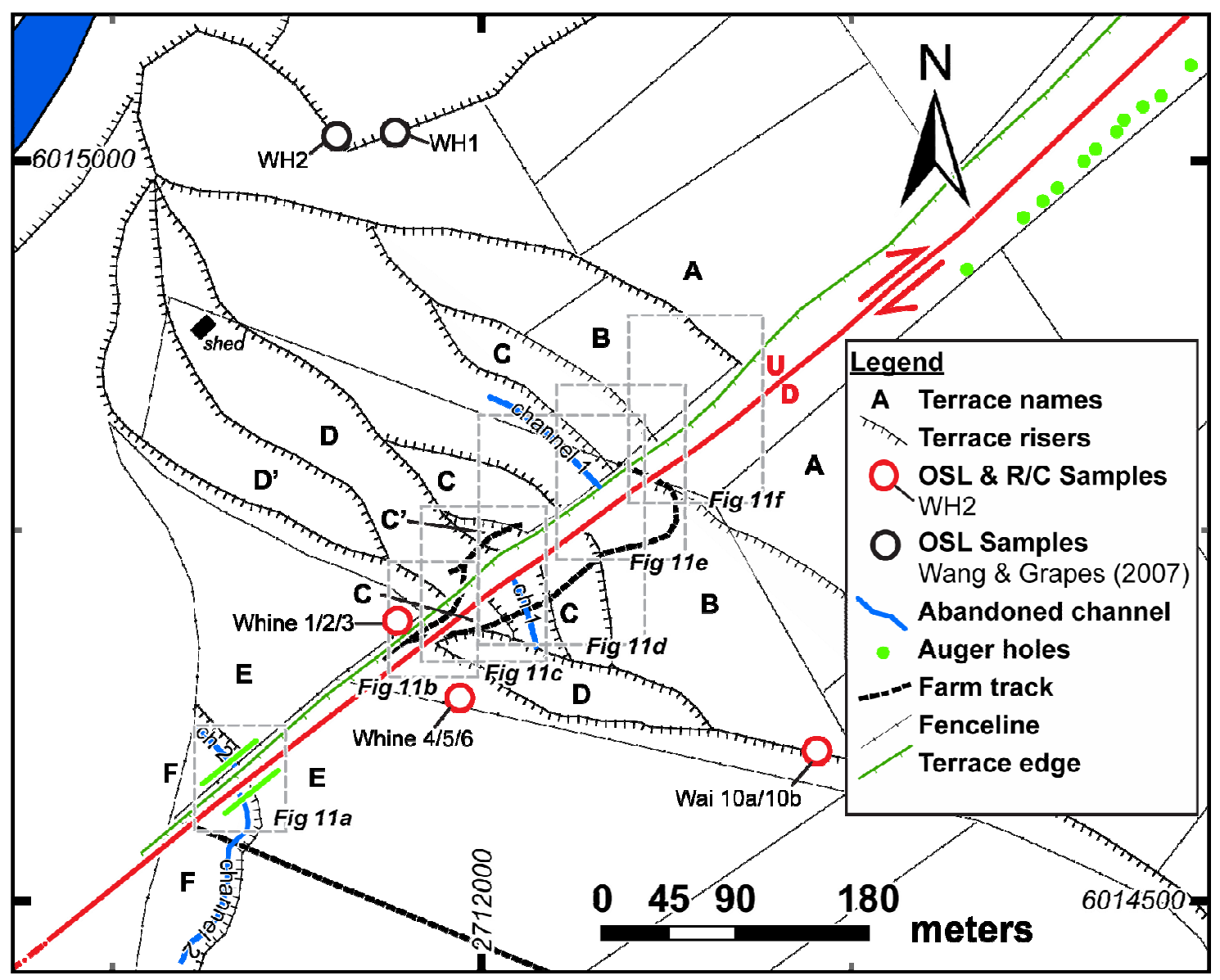

Figure 3. Simplified geomorphology and sample locality map of terrace sequence at Waiohine River. Wairarapa Fault is in red. Terrace A corresponds to the oldest and highest terrace in the sequence, the aggradational Waiohine surface. Degradation terraces labelled Terrace $B$ through to youngest terrace, Terrace F. Locally developed terraces C' and D' may represent locally developed paleotopography on terraces $C$ and $D$, respectively, and are not repreated on the south east side of the fault. Distinct paleochannels include Channel 1 (Ch1) and Channel 2 (Ch2). Red circles are locations of OSL and radiocarbon samples from this study. Black circles are previously published OSL dating results of Wang and Grapes (2007). Green circles show extent of targeted auger survey across Terrace A. Coordinates are in NZMG. Areas of Figures $11 \mathrm{a}-\mathrm{f}$ are denoted by dashed boxes. For location of map see Figure 2. 


\subsection{Geomorphology and Age of the Faulted Waiohine Terraces}

\subsubsection{Previous studies at the Waiohine terraces}

Lensen and Vella (1971) described a flight of eight terraces (Figure 4a), which they named A through to $\mathrm{H}$ (A being the oldest and highest and $\mathrm{H}$ being the youngest and lowest of these terraces). They reported seven vertical displacements of these terraces, and five horizontal displacements of channels and risers between these terraces (Table B1-1). Their vertical displacements of terrace surfaces were measured with a level and rod with an estimated accuracy of $\sim 0.15 \mathrm{~m}$, and their horizontal displacements were measured with measuring tape with an estimated accuracy of $\sim 0.9 \mathrm{~m}$. They assumed that the displacement of a terrace riser is most precisely dated by the abandonment age of that riser's lower bounding terrace tread; however, no age data were presented in the paper.

Grapes and Wellman (1988) mapped the Waiohine terraces on vertical aerial photos on an approximate scale of 1:17,000. They describe a flight of seven terraces (Ag3 and terraces AF). Of these, Ag3 is the oldest and highest Waiohine aggradation surface, whereas terraces A-F are degradational terraces, terrace $\mathrm{F}$ being the youngest and lowest (Figure $4 \mathrm{~b}$ ). They report seven vertical displacements of the terraces measured from the difference in terrace tread elevations across the Wairarapa Fault, and six dextral displacements measured from the mid-points of corresponding terrace risers across the fault (Table B1-1). Because their interpretive maps lack topographic contours, and their displacement measurements are not accompanied by methodological explanations, survey data, or assessments of error, these results are difficult to evaluate. The errors for all dextral and vertical offset measurements were later uniformly quoted as \pm 1 metre by Grapes (1999). These authors appear to interpret that a terrace riser is most precisely dated by the abandonment age of its lower bounding terrace tread, although this assumption is not clearly stated.

\subsubsection{Collection of new displacement and age data at the Waiohine terraces}

In this study, we reinterpret the displacements of geomorphic features across the Wairarapa Fault at the Waiohine River terraces, and compare our mapped terrace sequence to the two previous interpretations described above. We mapped the terrace sequence using $~ 1: 3,000$ scale colour vertical aerial photographs and modern geospatial techniques. A Trimble R8 GNSS RTK GPS (Appendices A1 \& A2) and a Sokkia 3030R EDM laser ranging theodolite (Appendices A3 \& A4) were used to collect over 18,000 topographic data points ( $\pm 1 \mathrm{~cm}(2 \sigma)$ horizontal and $\pm 18 \mathrm{~cm}(2 \sigma)$ vertical precision) across the terrace sequence. The data were krigged, gridded at a grid spacing of 1-4 $\mathrm{m}$ (4 $\mathrm{m}$ for larger scale maps and 1 

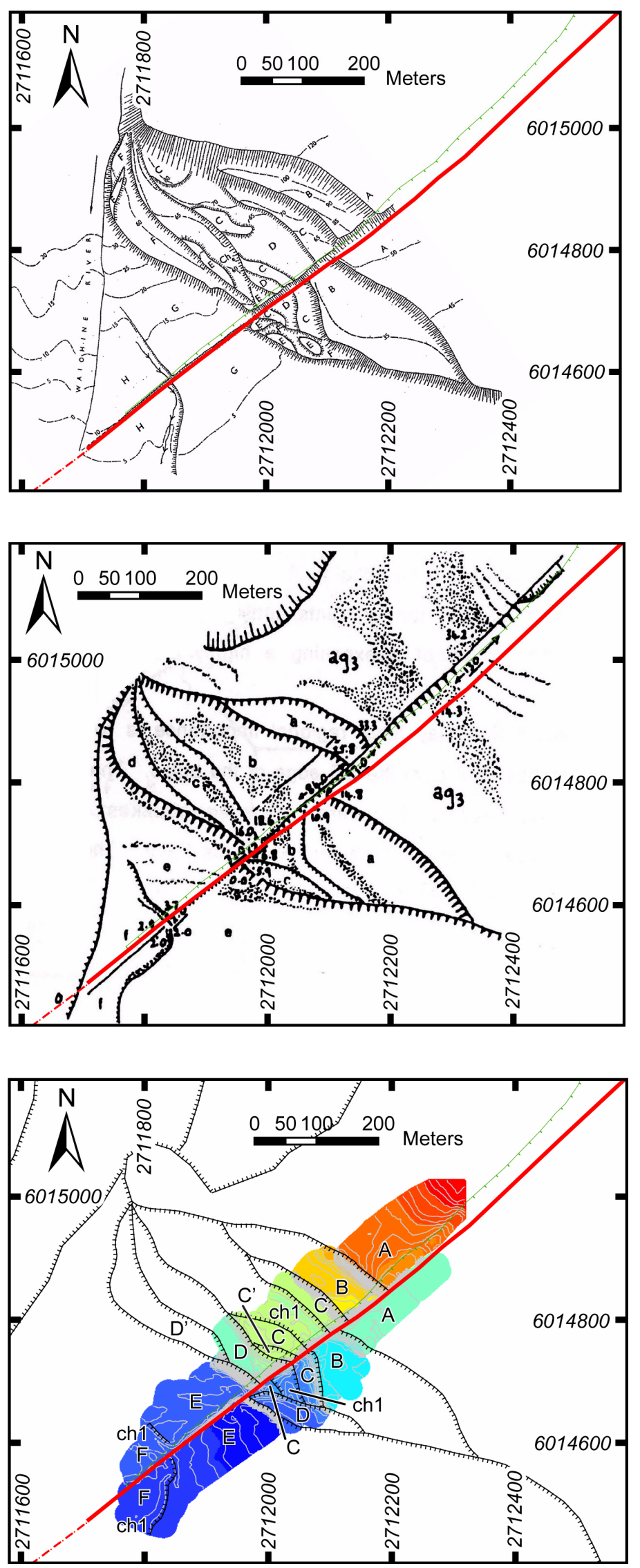

Figure 4c. Revised interpretation of the terraces at Waiohine River based on this study. Six terraces were identified (A-F, where A corresponds to the Waiohine aggradation surface), two sub-terraces ( $C^{\prime}$ and D') and two paleochannels (Ch1 and Ch2). Interpretation during this study was based on modern geospatial methods (see Appendices 1 \& 2). Differences between previous studies and this study are described in Section 2.4.2 \& Appendix B2. Wairarapa Fault is in red. Terrace edge/top of fault scarp is in green. Coordinates are in NZMG. 
$\mathrm{m}$ for smaller scale individual offsets) and variously contoured using ArcMap, ArcGIS software to produce microtopographic maps or DEM's (Appendix A5) for the terrace sequence (Figure 4c \& Figure A5-1) and for each specific terrace and riser displacement (Figures 11a-f). From these maps, precise estimates of vertical $(<10 \mathrm{~cm}$ uncertainty at $2 \sigma$ level) and horizontal displacements (generally $<3 \mathrm{~m}$ uncertainty, estimated to represent $2 \sigma$ level) were made from each terrace and riser, respectively. We collected a suite of 9 OSL and 2 radiocarbon samples from above and below the treads of two terraces at four different sites at and near the Waiohine terraces (Figures $2 \& 3$, Table 1). OSL samples were dated in the Victoria University of Wellington OSL Laboratory, and radiocarbon samples were dated at the Waikato University Radiocarbon Laboratory.

Our map and its interpretation differ in detail from those of Lensen and Vella (1971) and Grapes and Wellman (1988). We identify only six terraces, and the location and trend of terrace riser segments (risers $\mathrm{AB}, \mathrm{BC}$ and $\mathrm{CD}$ ) near the fault determined in this study are also different to previous studies (Figures 4 \& A5-1). We identified six main terrace surfaces (A-F, where $\mathrm{A}$ is the Waiohine surface) and two indistinct or locally developed terraces $\left(C^{\prime}\right.$ and $\left.D^{\prime}\right)$. In addition we mapped two paleochannels; Ch1, incised into terrace $C$, and $\mathrm{Ch} 2$, incised into terrace F (Figures 3 \& 4c). Differences between our mapped interpretation and those of previous studies are described in more detail in Appendix B2.

\subsubsection{Displacement of the Waiohine surface}

The Waiohine surface (our terrace A) is the most extensive aggradation terrace in the Wairarapa Valley (Begg \& Johnston, 2000), and is vertically and laterally displaced by the Wairarapa Fault. This fluvial surface formed by the coalescence of alluvial fans along the Tauwharenikau, Waiohine, Waingawa and Ruamahanga Rivers (Grapes, 1991). Aggradation of the Waiohine gravels was rapid enough to obliterate geomorphic evidence of fault displacements during their deposition (Lensen \& Vella, 1971). This section describes the previously reported displacements of the Waiohine surface at Waiohine River, and our attempt to construct detailed maps of these displacements.

A horizontal displacement of $\sim 120 \mathrm{~m}$ was attributed to the Waiohine surface at the Waiohine terraces by Wellman (1955). He based this offset on the vertical displacement of the terrace, together with the vertical to horizontal slip ratio of the younger risers and degradation terraces below the Waiohine surface, as no horizontal offset landform on the Waiohine surface was identified by him. Lensen and Vella (1971) similarly did not identify any landforms on the Waiohine surface at Waiohine River, from which a horizontal 


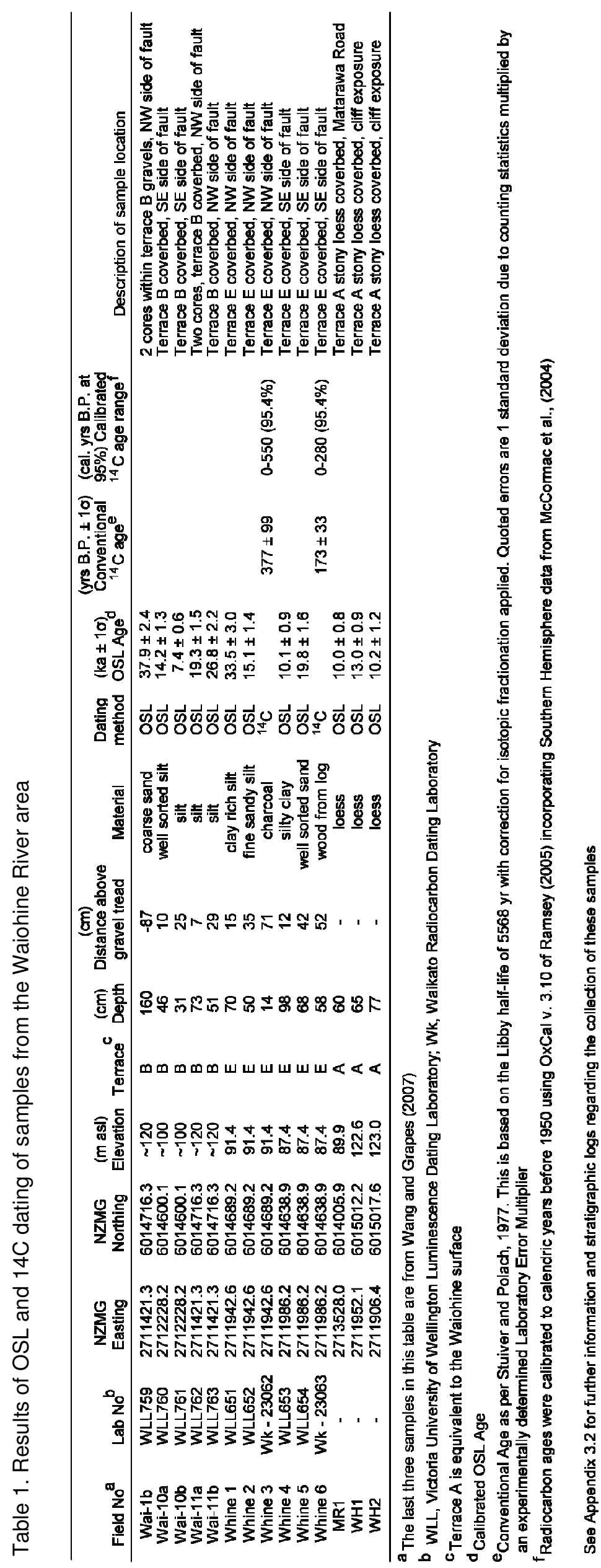


displacement could be inferred, claiming that 'no reference line in the Waiohine surface has been preserved' (Lensen \& Vella, 1971). They inferred a $\sim 120 \mathrm{~m}$ minimum dextral slip for the Waiohine surface by extrapolating their minimum ratio of horizontal to vertical displacement of 5.4 and the vertical displacement of $18.3 \mathrm{~m}$ for the Waiohine surface (Lensen \& Vella, 1971). Grapes and Wellman (1988) describe nine localities along the Wairarapa Fault where either channel's incised into the Waiohine surface or hills/risers at the back of that surface have been dextrally displaced by 120-130 m, for which Grapes (1999) later attributed a consistent error of $\pm 5 \mathrm{~m}$ for all these displacements. From these data, Grapes (1999) estimated a mean dextral displacement relative to the Waiohine surface of $127 \pm 3$ metres (Grapes, 1999). At the Waiohine River, he inferred a dextral displacement of $130 \mathrm{~m}$ for the Waiohine terrace across the Wairarapa Fault. This estimate was based on an interpreted offset of four closely spaced channels identified by Grapes and Wellman (1988) as being incised into the Waiohine surface (Figure 4b).

We attempted to construct a detailed map of the above-mentioned channels on the Waiohine surface at Waiohine River by means of an RTK GPS-based survey across the proposed site of the channels on that surface on both sides of the fault. Contouring and profiling of the DEM (Figure 5) produced from these RTK GPS data (see Appendices A1, A2 \& A5 for detailed methodology) did not reveal any topographic evidence for the proposed channels. Two large depressions were observed on the upthrown side of the fault, one near riser $\mathrm{AB}$, the other $\sim 250 \mathrm{~m}$ further northeast, but they are nowhere topographically expressed on the downthrown side of the fault. Moreover, these two depressions are broad, $>100 \mathrm{~m}$ wide swales that could not be used to resolve a precise displacement estimate for the Waiohine surface, even if they were expressed on the southeast side of the fault. To further resolve the presence of the proposed set of channels on the Waiohine surface, we undertook an auger survey (Figure 5) across the Waiohine surface on the downthrown side of the Wairarapa Fault along the base of the fault scarp, measuring the depth to gravel on the Waiohine surface in the area where Grapes and Wellman (1988) mapped the four channels. Eleven auger holes were made in a faultparallel profile. Depths to gravel ranged between $6 \mathrm{~cm}$ and $15 \mathrm{~cm}$ for the 11 auger holes. We found no evidence for channels in the topography of the top of the terrace gravels, as would be expected if channels had been incised into this surface, as interpreted by Grapes and Wellman (1988). On this basis, we reject their dextral displacement based on the reported offset of these channels. 


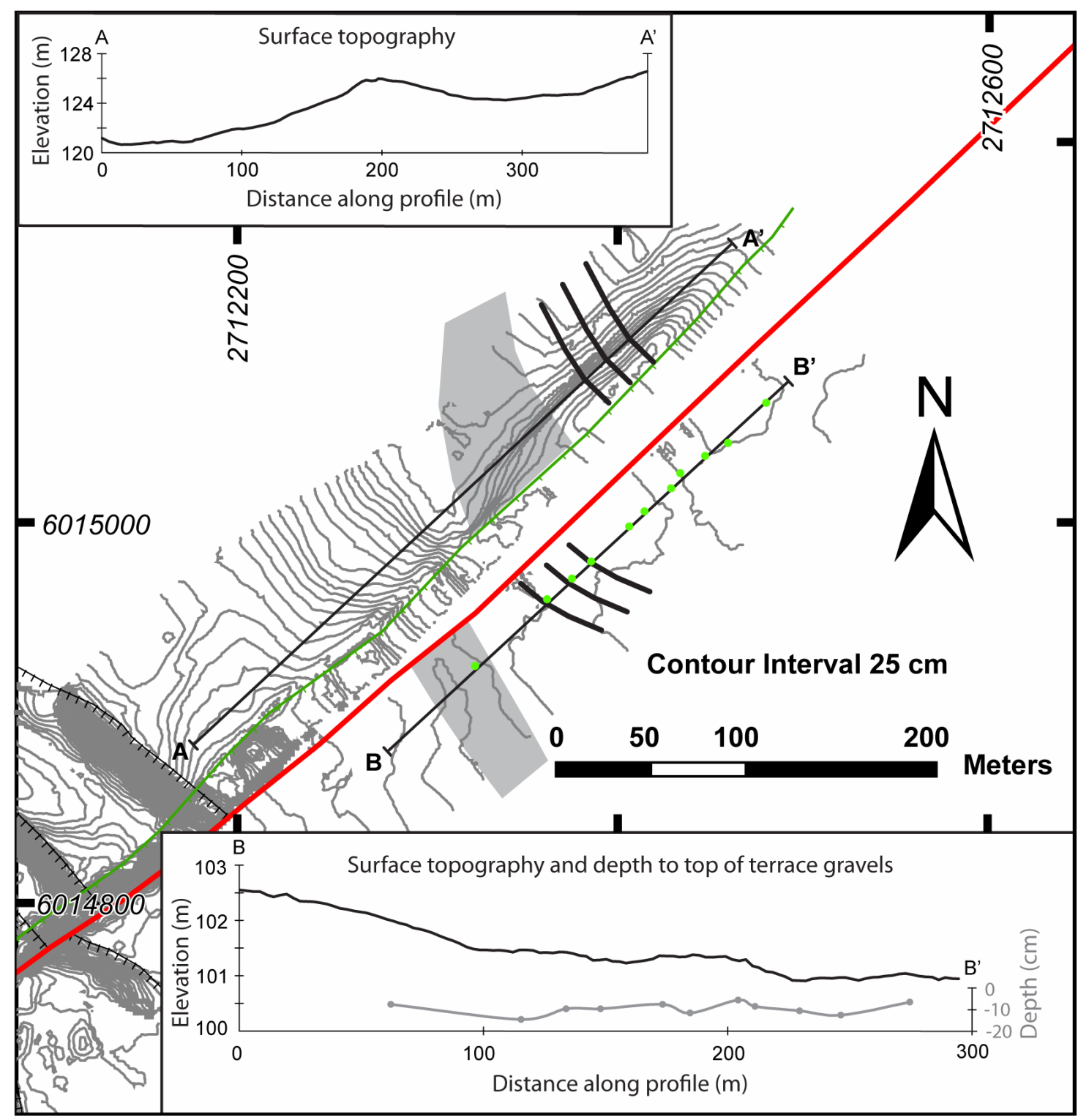

Figure 5. Looking for evidence of paleochannels on the Waiohine surface (after Grapes \& Wellman, 1988). Central part of figure shows topographic contours (interval $=25 \mathrm{~cm}$ ) based a Digital Elevation Model (DEM) derived from a Real-Time Kinematic (RTK) Global Positioning System (GPS) survey of terrace A (Waiohine surface). Light grey polgons and solid black lines indicate location of paleochannels according to Grapes and Wellman (1988). Green toothed line shows edge of terrace on upthrown side of Wairarapa Fault. Inserts show topographic profiles of the DEM across Terrace A surface on upthrown (A-A') and downthrown (B-B') sides of the fault. A-A' shows two broad depressions on the upthrown side of the fault; however, the downthrown side does not. Green dots are locations of auger holes in a targeted auger survey on the downthrown side of the fault to determine the depth to the top of the Terrace A gravels (B-B' insert in grey). In contrast to what was reported by Grapes and Wellman (1988), our data did not reveal any evidence for the existence of paleochannels incised into the top of the terrace gravels. 


\subsection{Previous Models for Progressive Fault Displacement of Flights of Degradational Terraces}

We describe three models for progressive lateral fault displacement during the formation of degradational river terraces. The first two models are end-member models that were first described by Suggate (1960). The third model is a hybrid model that falls between those two end-members and was described by Lensen (1964). We use Lensen's (1964) terrace nomenclature (Figure 6). For example, terrace tread is the nearly horizontal surface of fluvially deposited terrace gravels that represents the top surface of a now abandoned, former river bed (Figure 6); and terrace riser is the steep incisional slope between two adjacent river terraces that represents a former river bank (Figure 6).

The first end-member model (Figure 7a) assumes that after a lateral displacement on a fault, the river is unable to laterally erode or trim any of the displacement of its river banks. Time 1 (Figure 7ai) is after the first faulting event, $F_{1}$, and after subsequent river downcutting. After the first fault displacement, $F_{1}$, while the river occupies the younger terrace, there is no lateral erosion of the displaced riser (here called "lower riser"). The displacements of the lower and upper riser are the same, and there is no difference in the width of the older terrace across the fault. Any paleochannel that is incised into the stillactive younger terrace after $F_{1}$ remains straight and unfaulted. When the river downcuts to form a new river bank inset into the now abandoned, younger terrace, that younger terrace obtains a primary width difference (measured parallel to the fault) equal to the first fault displacement, $F_{1}$ (Figure 7ai). At Time 2 (Figure 7aii) after the second fault displacement, $\mathrm{F}_{2}$, there is once again, no lateral erosion of the newly faulted, currently active river bank. Any paleochannel incised into the younger terrace records one increment less displacement that the riser above it (i.e. $\mathrm{F}_{2}$ only). In this model the lateral displacement of a riser is equal to the displacement of any paleotopographic features incised into that riser's upper bounding terrace (e.g. paleochannels). That riser's lateral displacement is "fossilized" into the landscape from the initiation of incision of that riser into its upper bounding terrace, and so the lateral displacement of that riser is most precisely dated by the age of abandonment of its upper bounding terrace tread.

An example of where this model is most likely is where a narrow valley or gorge upstream of a strike-slip fault has been deeply incised into bedrock, while downstream of the fault the river debouches onto an alluvial flood plain or fan that becomes incised by a series of 


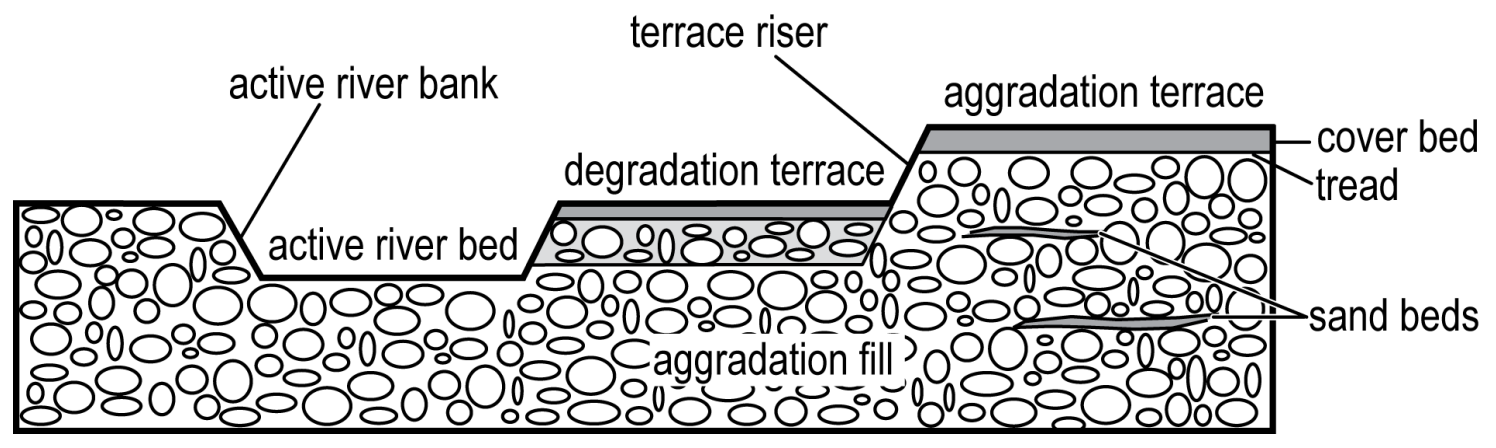

Figure 6. Selected alluvial terrace terminology. Aggradation fill, consisting mostly of gravel, is deposited by the river during times of sediment oversupply relative to the rivers carrying capacity. Aggradation terrace is the top surface of the aggradation fill. Degradation terraces are formed by erosion or incision by a river during subsequent downcutting into the aggradation fill. Some of the aggradation gravels may be reworked/redeposited to form a thin veneer on the degradation terrace. Aggradation fill commonly includes some sand beds deposited between much thicker gravel units. Both aggradation and degradation terraces can be mantled by cover beds of silt or loess transported as overbank deposits or as wind blown material. The tread of a terrace is the top of the terrace gravels below the younger cover bed. The active river bed and active river bank of a river will later become a terrace tread and terrace riser, respectively, when the river further incises to abandon that previous river bed and river bank. 


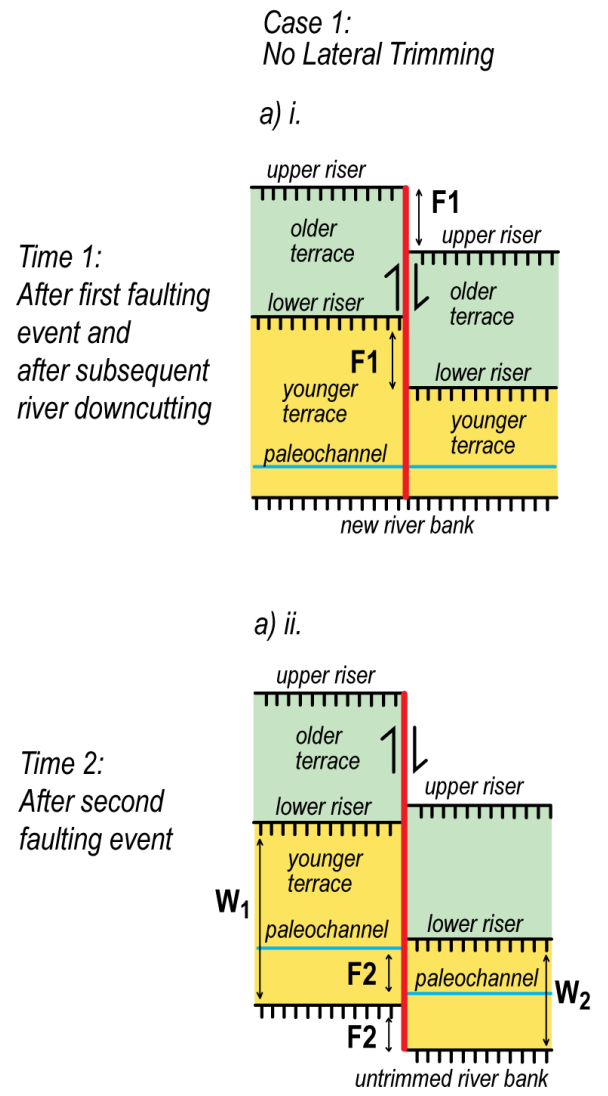

Case 2:

Complete Lateral Trimming

b) $i$.

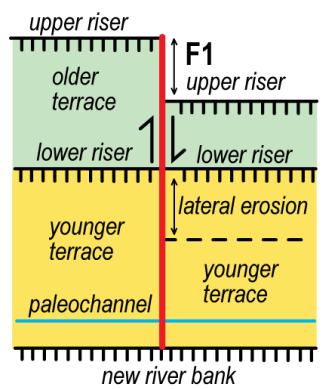

b) ii.

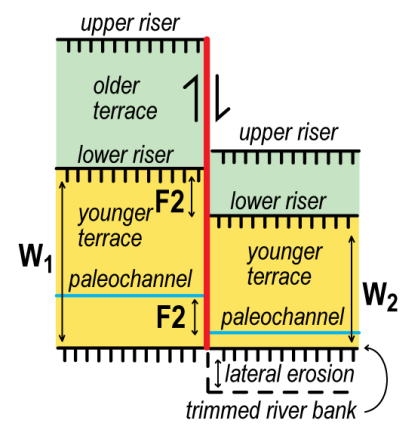

Case 3:

Partial Lateral Trimming

c) $i$.

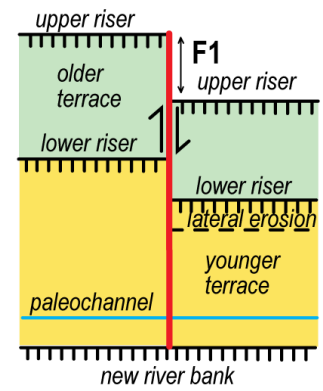

b) ii.

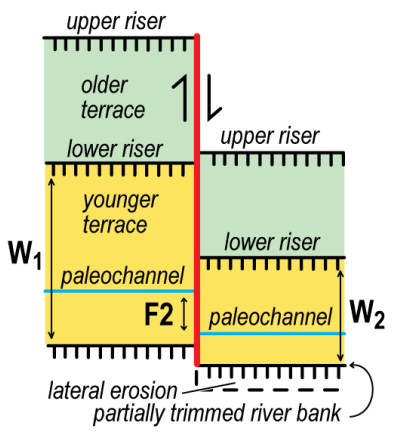

Figure 7. Two-stage (slip events $\mathrm{F} 1$ and F2) plan view models of a degradational terrace sequence undergoing the same amount of river downcutting and lateral faulting but different amount of lateral riser trimming (modified from Lensen, 1964a). Time 1 (i) is after the first faulting event and subsequent river downcutting that abandoned the younger terrace, and Time 2 (ii) is after the second faulting event. Case 1 (a) experiences no lateral trimming: Case 2 (b) experiences complete lateral trimming and: Case 3 (c) experiences partial lateral trimming. Red line is the fault and half arrows indicate dextral sense of motion; toothed lines are terrace risers; blue line is paleochannel; dashed line indicates displacement of riser before lateral erosion; F1 is the displacement associated with the first faulting event; F2 is the displacement associated with the second faulting event; W1 is the terrace width on the left side of the fault and; W2 is the terrace width on the right side of the fault. 
degradational terraces. The terraces are displaced laterally away from that fixed gorge to be immediately sequestered and thus preserved from lateral erosion on the "trailing edge" side of the river valley (Figure 8), whereas the "leading edge" on the downstream side of the river valley (Figure 8) is incisionally fixed to the point of intersection of the gorge with the fault and the river remains spatially attached here so no terrace risers form (e.g., Van Dissen et al., 2005; Zhang et al., 2007).

The second end-member model (Figure 7b) assumes that any lateral fault displacement is followed by rapid and complete lateral erosion of the displaced riverbanks by the still-active river occupying the lower surface of that riser. Lateral erosion can result in irregularities in the terrace sequence such as uncomplemented terraces, where a displaced terrace is completely removed by erosion on one side of the fault (Suggate, 1960). After the first fault displacement, $F_{1}$, while the river occupies the younger terrace, there is complete lateral erosion of the displaced lower riser (Fig 7bi). This erosion causes a difference in the width of the older terrace across the fault that is equal to the first fault displacement, $\mathrm{F}_{1}$. When the river downcuts to form a new and lower river bank, the younger terrace tread and any paleochannels incised into it become abandoned (Fig 7bi). At Time 2 (Figure 7bii), after the second fault displacement, $\mathrm{F}_{2}$, there is once again, complete lateral erosion of the newly faulted, currently active river bank. This lateral erosion causes a difference in width of the younger terrace across the fault that is equal to the second fault displacement, $F_{2}$. Any paleochannel incised into the younger terrace records only the second fault displacement, $\mathrm{F}_{2}$, the same displacement as that of the nearest riser above it. In this model, the lateral displacement of the riser (e.g. lower riser) is equal to the displacement of any paleotopographic features incised into that riser's lower bounding terrace (e.g. paleochannels). That risers lateral displacement is "fossilized" into the landscape from the time of abandonment of the risers lower bounding terrace, when the river that occupied that terrace can no longer completely trim any displacement of its former river bank, and so the lateral displacement of the riser is most precisely dated by the age of abandonment of that risers lower bounding terrace tread.

The third model (Figure 7c), a hybrid that falls between the two end-member models assumes that the lateral fault displacement of the river bank is later only partially eroded or trimmed by the active river. After the first fault displacement, $F_{1}$, while the river occupies the younger terrace, there is incomplete lateral erosion of the displaced lower riser (Fig 7ci). This partial lateral erosion causes a difference in the width of the older terrace across the fault that is equal to the amount of lateral erosion (but less than $F_{1}$ ). When the river 
downcuts to form a new and lower river bank, the younger terrace tread and any paleochannels incised into it becomes abandoned (Fig 7ci), and a primary difference in width of the younger terrace across the fault is inherited. At Time 2 (Figure 7cii), after the second fault displacement, $\mathrm{F}_{2}$, there is once again, partial lateral erosion of the newly faulted, currently active river bank. This lateral erosion further contributes to the difference in the width of the youngest abandoned terrace. Only any paleotopographic features incised into the younger terrace (e.g. paleochannels) record the second fault displacement, $\mathrm{F}_{2}$. In this model, the magnitude of the lateral displacement of a riser will fall between that of the displacements of any paleotopographic features on that risers upper or lower bounding terraces. The age of the apparent lateral displacement of a riser is between the abandonment ages of its upper and lower bounding terrace treads.

In a similar way, the three models make analogous predictions about the progressive accumulation of vertical displacements on faulted river terraces (e.g., Lensen, 1964). The models (depicted in Figures 9a-c) predict only small changes in the gradient of the river across the fault due to co-seismic throw, and assume that away from the fault the regional river gradient remains the same before and after faulting. Figures $9 \mathrm{a}-\mathrm{c}$ only consider a case where the scarp is downhill-facing.

In the first model (Figure 9a) there is no downcutting or other modification of the fault scarp produced in the river bed by a vertical faulting event. In unconsolidated materials, this case is expected to occur only immediately after faulting, where a small waterfall would be formed for only a short period (Suggate, 1960). In this model, there would be no difference in riser height across the fault.

In the second model (Figure 9b), after a short period of no downcutting, there is complete downcutting and smoothing of the co-seismically introduced fault scarp by erosion of the riverbed on the upthrown side of the fault (light grey). The knickpoint created by the fault scarp slowly migrates upstream and decrease in inclination (e.g., Arrowsmith and Rhodes, 1994). This case is more likely for a river that is incising into a more resistant lithology.

In the third model (Figure 9c), after a short period of no downcutting, there is partial downcutting of the fault scarp by erosion (light grey) of the riverbed on the upthrown side of the fault, and deposition of that eroded material (dark grey) on the downthrown side of the fault, resulting in complete removal of the scarp in the river bed. This case is most likely for the longer term response of a bed-load dominated alluvial river. The response of 


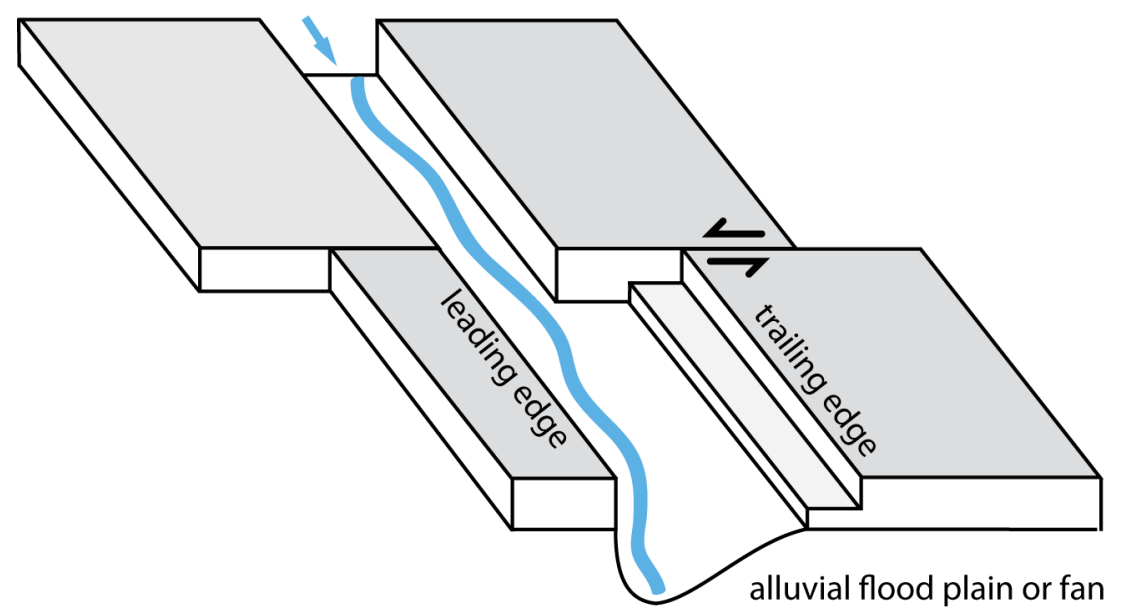

Figure 8. Narrow valley or deeply-incised gorge opening onto alluvial plain across an active strike-slip fault. With lateral displacement, the riser on the trailing edge is displaced away from the valley/gorge, and is protected. While the riser on the leading edge is incisionally fixed to the point of intersection of the valley/gorge with the fault, therefore no terrace risers are formed here.

a) Immediately After Faulting

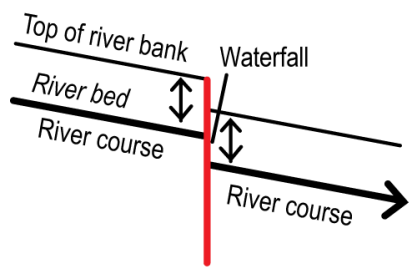

b) Complete Downcutting by Erosion

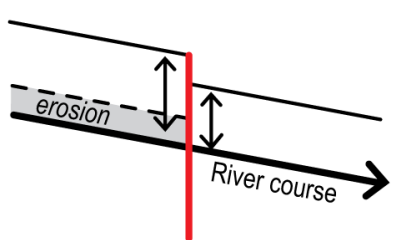

\section{c) Partial Downcutting with Erosion and Deposition}

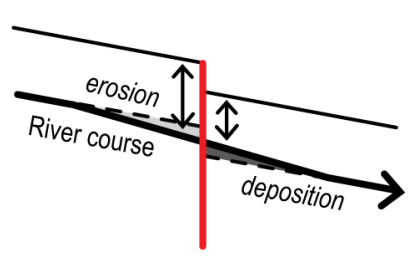

Figure 9. Cross sectional models of a river bed and bank undergoing the same amount of vertical faulting (case where upstream side of fault is upthrown) but different amounts of river downcutting (modified from Lensen, 1964a). Here we consider only cases where the scarp in the riverbed is downhill facing. a) River bank immediately after vertical faulting where no downcutting of the fault scarp in the river bed has occurred. b) complete downcutting of the fault scarp in the river bed by erosion. c) some downcutting of the fault scarp in the river bed with erosion on the upthrown side of the fault and deposition on the downthrown side. Heavy black lines are the active river level showing direction of river flow; thin black line is the top of the river bank; red line is the fault; dashed lines indicate location of river bed prior to faulting; small arrows indicate height of riser on upthrown and downthrown sides of the fault; light grey indicates areas of downcutting and; dark grey indicates areas of deposition. 
an alluvial gravel-bed river to a vertical scarp in its bed has been documented both experimentally and in a natural environment. The experimental response was described by Malverti et al., (2007) as diffusive, where the upstream face of the scarp is eroded and deposited downstream so that the scarp progressively smoothes around a knickpoint. The natural response of an alluvial gravel-bed river to such a vertical offset is most likely to be rapid. For example, the $\sim 2 \mathrm{~m}$ vertical scarp produced in the 1999 Chi-Chi earthquake in Taiwan was completely eroded from the bed of the Da-Jia River in less than 6 months (Malverti et al., 2007).

In models 2 and 3 above (Figures 9b \& 9c, equivalent to cases 2 and 3 in Figure 7b \& 7c), the height of the riser near the fault on the upthrown side will be greater than the riser height near the fault on the downthrown side, and this difference in height will be equal to the incremental throw of the risers lower bounding terrace. Any vertical displacement of the riverbed will be completely removed by the river, and so the vertical displacement of a terrace tread will only be recorded from the time of abandonment of that terrace tread. Therefore, the age of abandonment of that terrace tread most precisely dates any vertical displacement it records.

Cowgill (2007) presents six geomorphic indices that are useful in determining which model of progressive lateral displacement of flights of degradation terraces is most valid for a particular terrace sequence, and the most accurate age to assign to a terrace riser displacement. The indices are: (1) comparison of riser offset with inset channel width/displacement; (2) similarity of riser and tread displacements; (3) morphological analysis of the scarp profile; (4) riser deflection in plan view, where a riser that is curved in a sense consistent with the fault slip sense, suggests that the riser was incompletely trimmed prior to the lower terrace's abandonment; (5) diachroneity of terrace abandonment, where isochronous terrace abandonment suggests complete riser trimming as the river migrates quickly across the flood plain, while diachronous terrace abandonment suggests incomplete or no trimming as river migrates away from the riser for extended periods of time allowing riser displacements to be preserved; and (6) riser crests or bases yielding a fault slip vector, where the intersection between the active tread and the riser crest or base makes a piercing line that records fault motion occurring after the abandonment of the upper or lower terrace, respectively. The slip vectors recorded by these piercing lines can be compared to known slip vectors, or compared with slip vectors from other terrace-riser pairs in the sequence to identify any parallelism, if the slip direction is uniform over time (Cowgill, 2007). It is important to recognise that the difference in 
terrace width across the fault will in each case be equal to the incremental displacement of that terrace, and that a distinction between the different models cannot be made on the basis of a difference in terrace width.

\subsection{Method for Determining Horizontal and Vertical Displacements of Terraces and Risers}

At Waiohine River, vertical and horizontal displacements of each terrace, riser and paleochannel across the Wairarapa Fault were measured using the method outlined below. This method assumes a complete riser trimming model (justified in section 2.9.1), in which any vertical and lateral fault displacements are followed by rapid and complete erosion of the scarp in the river bed and displaced river bank (model 2 in Figures $7 \mathrm{~b}$ and 9b), until the river finally downcuts to abandon that fully trimmed terrace and riser.

1. To measure displacements across the fault, offset terraces, risers or channels were matched across the fault on microtopographic maps. The mean elevations of each terrace tread were calculated from elevation data points (usually at least 50) close to the fault on the adjacent upthrown and downthrown sides of the fault (Figure 10). The difference in these mean elevations at the fault gives a precise vertical displacement or throw estimate, with a standard error $<9 \mathrm{~cm}(2 \sigma)$.

2. The terrace risers at the Waiohine terraces have probably retreated as a result of erosion at the top of each riser, and advanced by deposition of younger colluvial sediment at the base. We assume that the middle of each riser is most likely to be unmodified. For each riser, a contour was arbitrarily selected on the downthrown side of the fault at approximately the mid-point of the riser. We assume that this contour is a linear marker of fault motion that has remained unmodified by erosion or deposition. On the upthrown side of the fault, an originally corresponding topographic contour was selected to match the mid-point contour chosen on the downthrown side. This second contour was chosen on the basis of the throw measurement, to differ in elevation from the first one by exactly the throw magnitude of the risers lower terrace surface (Figure 10). These two contours are assumed to have been matched and continuous with one another at the time of abandonment of that riser's lower bounding terrace and prior to subsequent faulting of the riser. For paleochannels incised into terrace surfaces, the thalweg of the channel was selected on both sides of the fault as having the lowest elevation of the immediately 


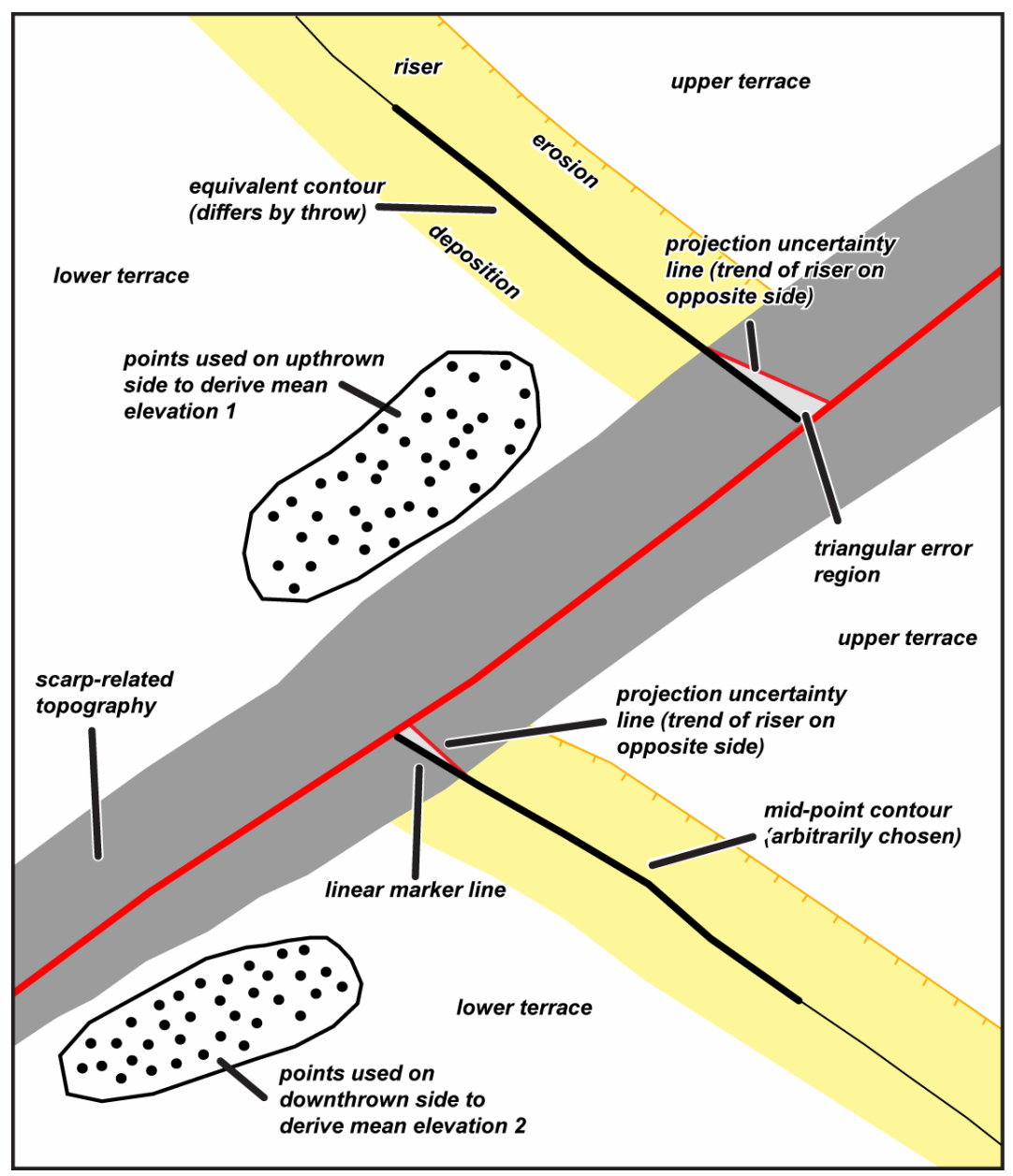

Figure 10. Method of calculating displacements as based on a complete lateral riser trimming model. (1) Mean elevations of equivalent terraces across the fault are found from GPS points close to the fault, from which the vertical displacement can be estimated (Throw = 1 - 2). (2) A mid-point contour is selected on the downthrown side of the fault and the equivalent contour is found on the upthrown side that differs by the vertical displacement magnitude. (3) A grey polygon is drawn to represent topography near the scarp that has been modified by erosion or deposition. ( $4 \& 5)$ The trends of the fault-proximal parts of the risers are projected linearly across this grey area to hit the fault, giving an estimate of horizontal displacement. (6) Triangular error regions (assumed to approximate $2 \sigma$ errors) are determined by projecting uncertainty lines that satisfy assumption that riser trends were once identical at the fault. Section 6 describes this method in detail. 
surrounding points. The thalwegs are also assumed to have once been matched and continuous.

3. A (grey) polygon was drawn to represent that part of the topography near the fault trace that has been modified to form the fault scarp (Figure 10). This topography has been modified by a mixture of erosion and/or deposition (and/or anthropogenic) processes. The edge of the area defined by the polygon was generally taken to coincide with that point in the topography where the terrace riser topographic contours deflect (often subtly) away from the main riser trend, and begin to curve inwards towards the trend of the nearby fault trace. In some cases, this polygon was drawn to include areas near the fault scarp where the density of RTK GPS and EDM points was particularly low, and apparent detail in the computer-generated contours produced was unrealistic and likely to be an artefact.

4. We assume that the mid-riser contours (or paleo-channel thalwegs) once had an identical trend at the point where they originally met at the fault. This follows directly from the "complete trimming" model which infers an originally linear and well trimmed riser shape prior to faulting. Where the risers have different trends today on either side of the scarp, one or the other (or both) of the risers or thalwegs must have curved in such a way that they once met identically at the fault (site of future fault scarp). In some cases, this last assumption influenced what area was included in the polygon and what area was considered relict riser topography; for example, a deflection in the trend of the riser nearest the fault may have been the result of the deposition of fault scarp material over the riser, and not a true riser deflection.

5. Linearly projecting the most fault-proximal segment of each preserved riser (i.e., that part nearest the fault, and immediately outside of the polygon, typically within the last $\sim 5-$ 10 metres of it), a best-fit extension of each marker line was projected to the fault trace (Figure 10). This linear projection of each riser segment is taken to be parallel to the mean trend of that set of nearby mid-riser contours that collectively give a mean trend of the riser near the fault, rather than relying exclusively on any single (arbitrarily-chosen) contour. In the case of a faulted channel, the trend of the thalweg was projected across the fault-scarp polygon to hit the fault on both sides. For both faulted risers and channels, the strike-slip displacement is measured as the distance between the two matched projection lines, as measured parallel to the fault. 
6. Triangular error regions were produced by drawing projection uncertainty lines on one side of the projected line segments to encompass the extreme range of possible curvature variations that could have led to the satisfaction of the assumption that the risers or thalwegs once met at the fault with the exact same trend (see step 4, above). The projection uncertainty line on one side of the fault was drawn with the same trend as the projected riser line segment for the equivalent riser on the other side of the fault (Figure 10). These asymmetric triangular error regions approximate $95 \%$ confidence regions in the location of each projected riser line segment. The root-mean-square (RMS) of the two projection uncertainties (one for each riser segment on either side of the fault) approximates a $95 \%$ confidence interval for that displacement (Figure 10). Any uncertainty in dextral displacement resulting from the uncertainty in the throw measurement (where the location of the matching mid-riser contour on the upthrown side of the fault may vary) is much smaller than this projection uncertainty, and is here considered to be negligible.

\subsection{Displacement Estimates for the Waiohine Terraces}

\subsubsection{Cumulative displacements}

Using the method outlined above, we measured cumulative dextral and vertical displacements of the Waiohine surface (terrace A) and five degradational terraces (terraces B-F) at the Waiohine River. The vertical and dextral displacements are described below from the youngest and lowest terrace (terrace F) through to the oldest and highest terrace (terrace A), followed by a comparison of our displacements with those measured in the two previous studies at the Waiohine River. The displacements are listed in Table 2, and Tables B3-1 and B3-2 show more detailed measurements. For each of the terraces in the sequence, the sense of throw was up-to-the-northwest. The Wairarapa Fault plane is not exposed in the Waiohine River gorge and its dip in that area is uncertain. Von Borstel and Ingham (2004) image the Wairarapa Fault at Tauwharenikau River using magnetotelluric sounding, with results that suggest the Wairarapa Fault may have a dip of $\sim 80^{\circ}$ northwest there. On the basis of modelling of gravity profiles in the Wairarapa Valley, Hicks and Woodward (1978) inferred a near vertical dip for the Wairarapa Fault at its northern end, decreasing to as low as $15^{\circ}$ at its very southern onshore end. On the basis of these studies, we assume a near-vertical fault plane for the Wairarapa Fault at the Waiohine River.

Terrace F (Figure 11a), the youngest terrace in the sequence, is vertically displaced by 1.30 $\pm 0.02 \mathrm{~m}(2 \sigma)$ across the Wairarapa Fault. The thalweg of paleochannel Ch 2 incised into 
terrace $\mathrm{F}$ is dextrally displaced by $12.4 \pm 0.8 \mathrm{~m}(2 \sigma)$. Terrace riser EF is dextrally displaced by $11.4 \pm 1.7 \mathrm{~m}(2 \sigma)$ (Figure 11a, Table 2, Tables B3-1 \& B3-2).

Terrace E (Figure 11b), the next youngest and higher terrace in the sequence (Figure 11b), is vertically displaced by $2.67 \pm 0.05 \mathrm{~m}(2 \sigma)$. Terrace riser DE is dextrally displaced by 22.1 $\pm 1.5 \mathrm{~m}(2 \sigma)$ (Figure 11b, Table 2, Table B3-1 \& Table B3-2). The calculated vertical displacement for terrace E was sensitive to the inclusion of RTK GPS points from a depression near the fault at the base of the DE riser (Figure 11b), which affected the average terrace elevation for the downthrown side of the fault. Points in this depression were not included in the calculation, as the depression was determined to have been produced by anthropogenic processes (construction of a farm track).

The next youngest terrace, terrace D (Figure 11c), is vertically displaced by $11.85 \pm 0.03 \mathrm{~m}$ $(2 \sigma)$. Terrace riser CD is dextrally displaced by $81.8 \pm 20.9 \mathrm{~m}(2 \sigma)$, within error of the dextral displacement recorded by riser BC (see below). The large error quoted for this measurement chiefly arises due to the difference in trend of the riser segments on either side of the fault, which yields a large uncertainty triangle when the risers are projected across the grey area to the fault (Figure 11c, Table 2, Tables B3-1 \& B3-2). For riser CD, our assumption of an initially linear riser at the fault may not be valid. Today, the river bank of the Waiohine River is locally curved, and we infer that riser CD formed where a small bend in the river crossed the fault. This has resulted in the currently preserved riser segments outside of the scarp region having quite different trends. Due to its large error, we choose to ignore the riser CD dextral displacement, so that our following calculations of incremental displacements and $\mathrm{H} / \mathrm{V}$ ratios do not inherit this large uncertainty.

The next youngest terrace, terrace C (Figures $11 \mathrm{~d} \& 11 \mathrm{e}$ ), is vertically displaced by $12.99 \pm$ $0.03 \mathrm{~m}(2 \sigma)$. Two dextral measurements were obtained from a paleochannel, Ch1, incised into terrace C. Dextral displacements of $85.8 \pm 9.9 \mathrm{~m}(2 \sigma)$ and $83.7 \pm 12.1 \mathrm{~m}(2 \sigma)$ were measured using 1) the thalweg of $\mathrm{Ch} \mathrm{1,} \mathrm{and} \mathrm{2)} \mathrm{the} \mathrm{northwest} \mathrm{edge} \mathrm{of} \mathrm{the} \mathrm{channel} \mathrm{(C-Ch1),}$ respectively. The large errors for these measurements are again chiefly due to the difference in trend of these geomorphic features on opposite sides of the fault, and in locating the thalweg of the channel on the downthrown side of the fault which was made difficult by the wide and shallow morphology of the paleochannel. These dextral displacements are within error of the dextral displacement of terrace riser BC, displaced by $73.2 \pm 2.3 \mathrm{~m}(2 \sigma)$ (Figures 11d \& 11e, Table 2, Tables B3-1 \& B3-2). 


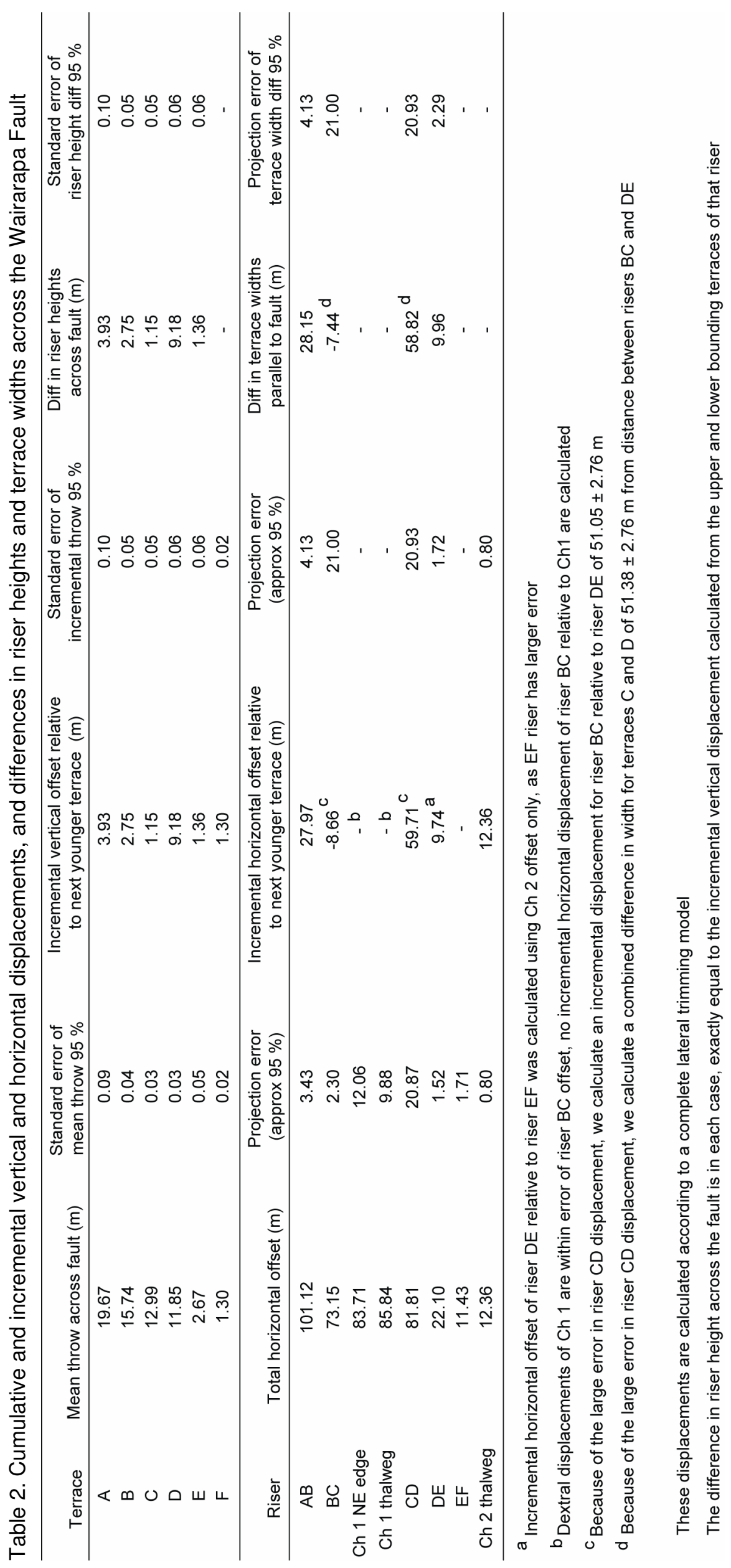



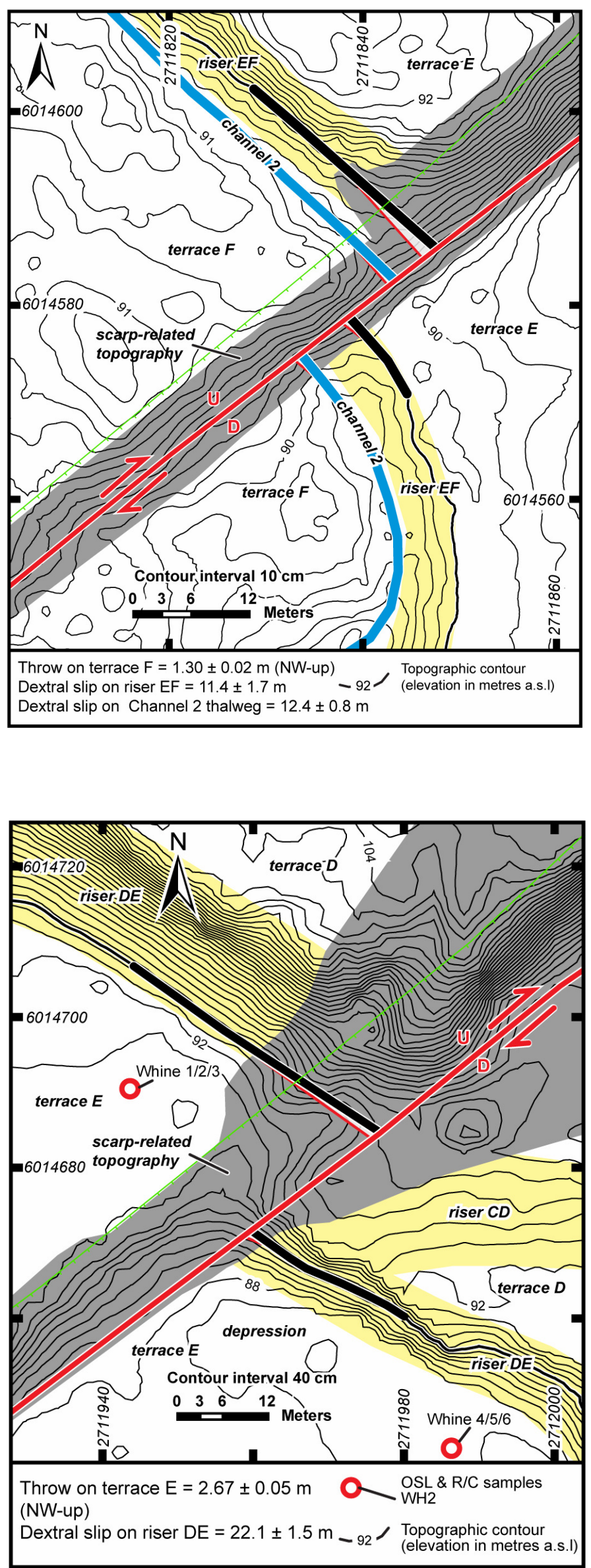

Figure 11a. Microtopographic map of terrace $F$, riser $E F$ and $C h 2$ displacements across the Wairarapa Fault. See Figure 3 for location. Map is based on a survey data set consisting of $\sim 4900$ points, which are omitted for clarity. On this topographic map the contour interval is $10 \mathrm{~cm}$. Projection uncertainty on downthrown side is too smale for map scale. Elevations are metres above sea level (m asl). Coordinates are in NZMG.

Figure 11b. Microtopographic map of terrace $E$ and riser $D E$ displacements across the Wairarapa Fault. See Figure 3 for location. Map is based on a survey data set consisting of $\sim 1850$ points, which are omitted for clarity. On this topographic map the contour interval is $40 \mathrm{~cm}$. 

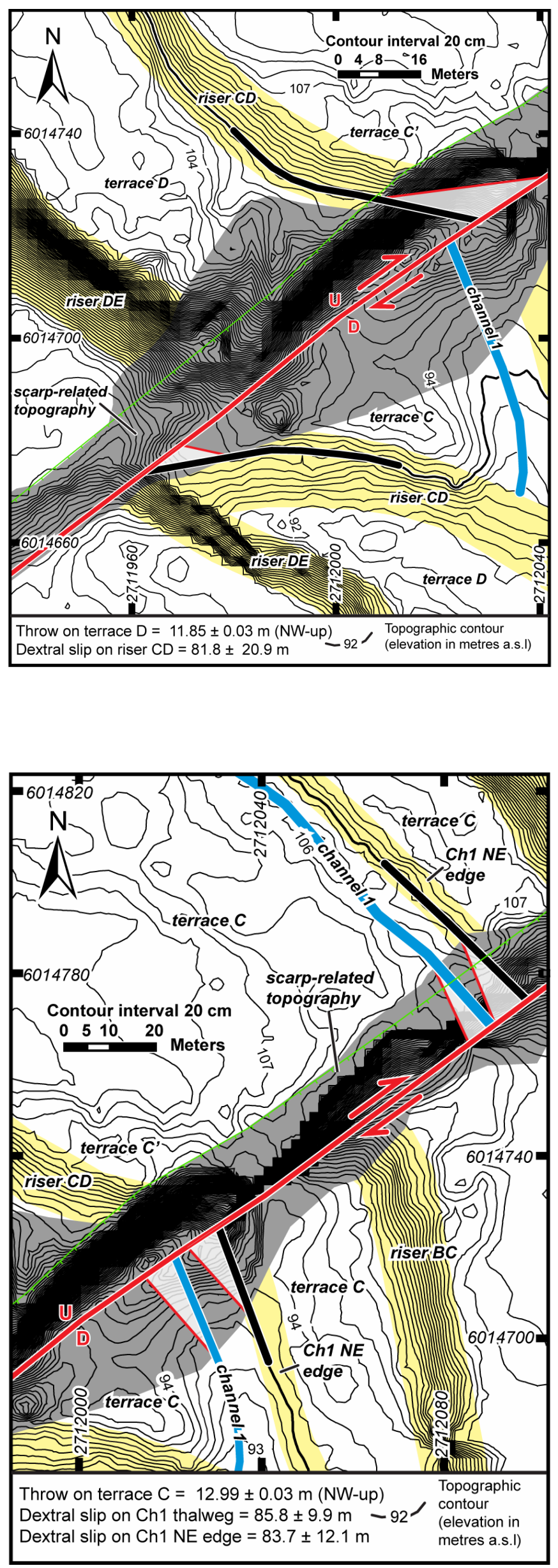

Figure 11c. Microtopographic map of terrace $D$ and riser $C D$ displacements across the Wairarapa Fault. See Figure 3 for location. Map is based on a survey data set consisting of $\sim 2920$ points, which are omitted for clarity. On this topographic map the contour interval is $20 \mathrm{~cm}$.

Figure 11d. Microtopographic map of terrace $\mathrm{C}$ and $\mathrm{Ch1}$ displacements across the Wairarapa Fault. See Figure 3 for location. Map is based on a survey data set consisting of 3620 points, which are omitted for clarity. On this topographic map the contour interval is $20 \mathrm{~cm}$. 

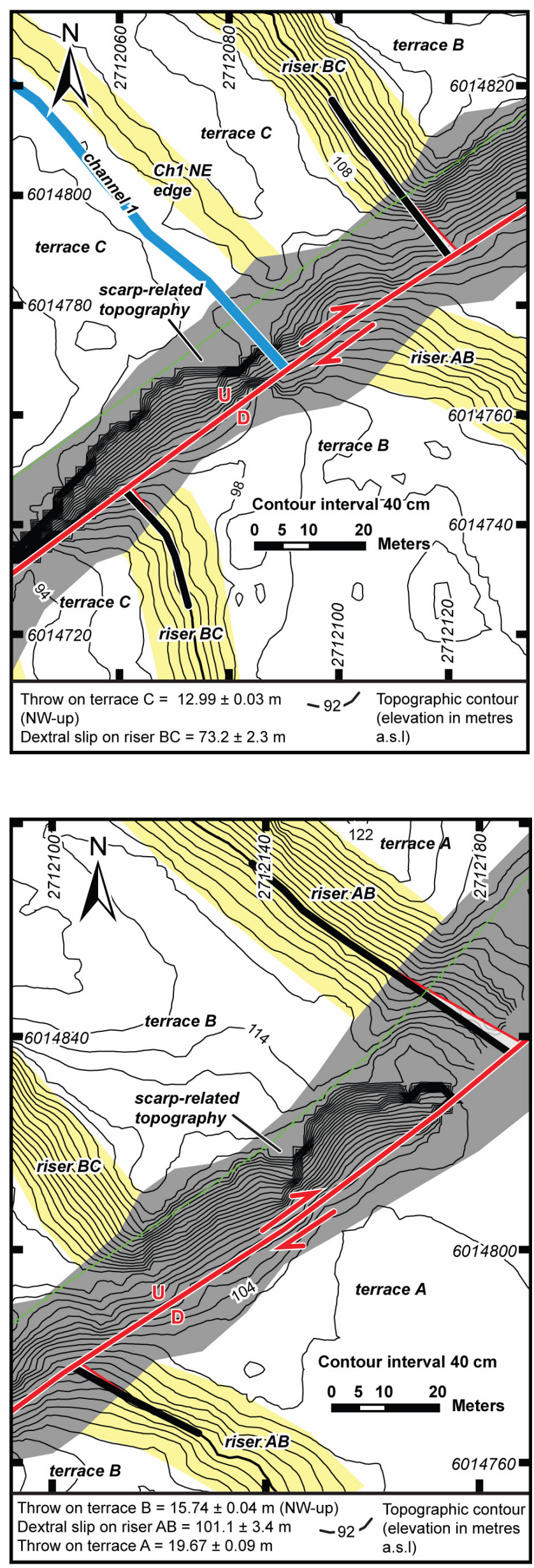

Figure 11e. Microtopographic map of terrace $\mathrm{C}$ and riser $\mathrm{BC}$ displacements across the Wairarapa Fault. See Figure 3 for location. Map is based on a survey data set consisting of $\sim 3540$ points, which are omitted for clarity. On this topographic map the contour interval is $40 \mathrm{~cm}$.

Figure 11f. Microtopographic map of terrace $A$, terrace $B$ and riser $A B$ displacements across the Wairarapa Fault. See Figure 3 for location. Map is based on a survey data set consisting of $\sim 2790$ points, which are omitted for clarity. On this topographic map the contour interval is $40 \mathrm{~cm}$. 
The next youngest terrace, terrace B (Figure 11f), is vertically displaced by $15.74 \pm 0.04 \mathrm{~m}$ $(2 \sigma)$. Terrace riser $\mathrm{AB}$ is dextrally displaced by $101.1 \pm 3.4 \mathrm{~m}(2 \sigma)$, the largest dextral displacement measured at the Waiohine terraces in this study (Figure 11f, Table 2, Tables B3-1 \& B3-2).

Terrace A (Waiohine surface), the oldest terrace in the sequence, is vertically displaced by $19.67 \pm 0.09 \mathrm{~m}(2 \sigma)$. No dextral displacement measurements were obtained for this terrace, as described in detail in section 2.4.3 (Figures $5 \& 11 \mathrm{f}$, Table 2, Table B3-1). The uncertainty in the mean vertical displacement of terrace A, calculated following the method described in section 2.6, may underestimate the uncertainty. The elevation of that surface on the upthrown and downthrown sides of the fault varies from the mean elevation by a maximum of $\pm 2.5 \mathrm{~m}$ due to later formation of long wavelength depressions. However, the above uncertainty of $\pm 0.09 \mathrm{~m}$ is calculated from the standard deviations of the mean terrace elevations on the upthrown and dowthrown sides of the fault, which were calculated from $>1800$ topographic data points within $\sim 50 \mathrm{~m}$ of the Wairarapa Fault over an area of $\sim 40,000 \mathrm{~m}^{2}$, therefore such depressions are included in the mean terrace elevation calculations. The smaller uncertainty estimate is used for all calculations in the remainder of this thesis.

Our measured displacements differ from those reported by Grapes and Wellman (1988) and Lensen and Vella (1971) in the following ways. For all six terraces, the estimates of vertical displacement made by either Grapes and Wellman (1988) or Lensen and Vella (1971), and in some cases both authors, are smaller than the throw estimates from this study by up to $1.5 \mathrm{~m}$ (Table 3). The dextral displacements are within error of those from the previous studies for four of the displacements, however, significant differences include the displacements of riser DE and riser BC, which in our study are up to $\sim 12 \mathrm{~m}$ and $\sim 10$ $\mathrm{m}$ smaller, respectively, than in the previous two studies (see Appendix B4 for detailed explanation).

\subsubsection{Incremental displacements}

Under a model of complete river bank trimming and river bed downcutting, the incremental lateral displacement that took place between the abandonment of two adjacent, differently displaced terraces is equal to the difference between the cumulative strike-slip of the respective risers at the back of each terrace (Figure 7). The corresponding incremental vertical displacement for two adjacent terraces is the difference between the cumulative throws of those terraces. The vertical and incremental displacements are described below 


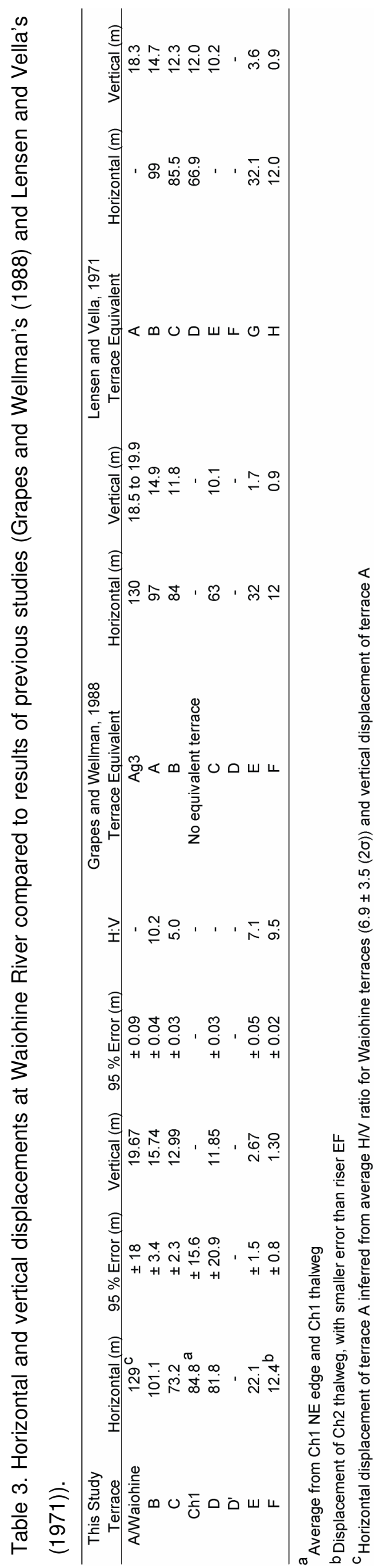

Carne, R. C. 
from the youngest terrace pair (terrace $F$, and the modern river) through to the oldest terrace pair (terrace A, and terrace B). The incremental displacements are listed in Table 2 (also see Tables B3-1 and B3-2). For each terrace pair, the incremental vertical displacement has an up-to-the-northwest sense. The uncertainties in the incremental dextral and vertical displacements were calculated by the RMS of the uncertainties of the two measurements (upper and lower terrace/riser displacements) used in the incremental displacement calculation.

The cumulative displacements for terrace F (Table 2, Tables B3-1 \& B3-2) are interpreted to represent the single-incremental displacements that occurred during the most recent Wairarapa Fault earthquake in 1855. Below terrace $\mathrm{F}$ is the active river bed and river bank that do not express any displacements. After subtracting the cumulative displacements of terrace $\mathrm{F}(\mathrm{Ch} 2)$ from those of terrace $\mathrm{E}$ (riser DE), terrace $\mathrm{E}$ has an incremental throw of $1.36 \pm 0.06 \mathrm{~m}(2 \sigma)$, and an incremental dextral slip of $9.7 \pm 1.7 \mathrm{~m}(2 \sigma)$ (Table 2, Tables B3$1 \&$ B3-2). The incremental vertical displacement between terraces $\mathrm{D}$ and $\mathrm{E}$ is $9.18 \pm 0.06$ $\mathrm{m}(2 \sigma)$, and the incremental vertical displacement between terraces $\mathrm{C}$ and $\mathrm{D}$ is $1.15 \pm 0.05$ $\mathrm{m}(2 \sigma)$ (Table 2, Table B3-1). The incremental dextral displacement between risers BC and $\mathrm{DE}$ is $51.1 \pm 2.8 \mathrm{~m}(2 \sigma)$. The incremental vertical displacement between terraces $\mathrm{B}$ and $\mathrm{C}$ is $2.75 \pm 0.05 \mathrm{~m}(2 \sigma)$, and the incremental dextral displacement between risers $\mathrm{AB}$ and $\mathrm{BC}$ is $28.0 \pm 3.5 \mathrm{~m}(2 \sigma)$ (Table 2, Tables B3-1 \& B3-2). The incremental vertical displacement between terraces A (Waiohine surface) and B is $3.93 \pm 0.10 \mathrm{~m}(2 \sigma)$ (Table 2, Table B3-1).

\subsection{Terrace Ages at Waiohine River}

\subsubsection{Samples collected}

We collected nine Optically Stimulated Luminescence (OSL) samples and two radiocarbon samples from terraces $\mathrm{E}$ and $\mathrm{B}$ at the Waiohine River to constrain the ages of their abandonment. Terrace E was dated to support our inference that paleochannel Ch2 incised into terrace $\mathrm{F}$ displays a dextral displacement generated in the 1855 earthquake. Terrace B was dated to constrain the Late Quaternary slip rate on the Wairarapa Fault at Waiohine River. The locations of the 11 dated samples are shown in Figures 2 and 3. The location, lithology and stratigraphic context of each sample is described below, and summarised in Table 1 and Figure C1-1. Samples were mostly collected from coverbeds of fluvial overbank silt deposited on the gravel terrace treads. The OSL samples of silt and sand were collected by inserting steel tubes into cleaned vertical faces (cliff or pit faces) (Figure C1-1). OSL samples were submitted to the Victoria University of Wellington OSL Laboratory, 
and radiocarbon samples were dried in an oven and hand-picked before being submitted to the University of Waikato Radiocarbon Laboratory.

Four OSL and two ${ }^{14} \mathrm{C}$ samples were collected from the terrace $\mathrm{E}$ coverbeds at the Waiohine River terraces. Samples Whine 1 (OSL), Whine 2 (OSL), and Whine $3\left({ }^{14} \mathrm{C}\right)$, were collected from silts overlying terrace gravels on terrace $\mathrm{E}$ at the Waiohine River terraces, on the upthrown side of the Wairarapa Fault (Figure 3, Table 1 \& Figure C1-1). Whine 1 is an OSL sample consisting of a clay-rich silt, Whine 2 is an OSL sample consisting of a fine sandy silt, and Whine 3 is a ${ }^{14} \mathrm{C}$ sample consisting of charcoal. Samples Whine 4 (OSL), Whine 5 (OSL), and Whine $6\left({ }^{14} \mathrm{C}\right)$, were collected from silts overlying terrace gravels on terrace $\mathrm{E}$ at the Waiohine River terraces, on the downthrown side of the Wairarapa Fault (Figure 3, Table 1 \& Figure C1-1). Whine 4 is an OSL sample consisting of a silty clay, Whine 5 is an OSL sample consisting of a well-sorted sand, and Whine 6 is a ${ }^{14} \mathrm{C}$ sample consisting of wood that was collected from part of a large log (away from the OSL sample cores).

Five OSL samples were collected from above and below the gravel tread of terrace B at the Waiohine terraces. Sample Wai-1b consists of coarse sands that was collected from sands occurring interbedded with fluvial terrace gravels of terrace B, from the Waiohine River bank on the western side of the river (opposite side to the terrace sequence), on the upthrown side of the Wairarapa Fault (Figure 2, Table 1 \& Figure C1-1). Samples Wai-11a and Wai $11 \mathrm{~b}$ are OSL samples consisting of well sorted silt that were collected from silts overlying terrace gravels on terrace B at the same location as Sample Wai-1b (Figure 2, Table 1 \& Figure C1-1). Samples Wai-10a and Wai-10b are OSL samples of silt that were collected from the coverbed above the terrace gravels on terrace $\mathrm{B}$ at the Waiohine terraces, on the downthrown side of the fault (Figure 3, Table 1 \& Figure C1-1). Both samples (Wai-10a and Wai-10b) consist of well sorted silt, with Wai-10a collected from a stratigraphically lower position that Wai-10b.

\subsubsection{Optically Stimulated Luminescence (OSL) dating technique}

The nine submitted samples contained plenty of silt, so we decided to use the 4-11 $\mu \mathrm{m}$ grain size fraction for dating. A multiple aliquot additive dose protocol (Lang and Wagner, 1996) was applied to obtain the equivalent dose. Sample preparation followed standard finegrain procedures (e.g. Wang, 2001). 
Luminescence measurements were done using a Riso TL-DA15 measurement system, equipped with infrared LEDs $\left(880 \Delta 80 \mathrm{~nm}, 30 \mathrm{~mW} / \mathrm{cm}^{2}\right)$ to stimulate the feldspars in the polymineral sample, and Schott BG39 + Kopp 5-58 optical filters to select the blue luminescence band around $410 \mathrm{~nm}$. $\beta$-irradiations were done by the built-in ${ }^{90} \mathrm{Sr},{ }^{90} \mathrm{Y} \beta$ irradiator, calibrated against a gamma-irradiated finegrain feldspar standard material to $3 \%$ accuracy. $\alpha$-irradiations were done on a ${ }^{241} \mathrm{Am}$ irradiator supplied and calibrated by ELSEC, Littlemore, UK.

The Paleodose was estimated by use of the multiple aliquot additive-dose method with latelight subtraction (6 additive $\beta$-doses, 3 additive $\alpha$-doses to determine the a-value, 4 weeks storage after irradiation, preheat $220^{\circ} \mathrm{C}$ for 5 min, OSL measurement with $100 \mathrm{~s}$ shinedown time). Using the program Analyst the curves were shortshine-normalised, and the late light, which can be attributed to background and less light-sensitive electron traps that may not have been bleached at sample deposition, subtracted. This method allows dating of only briefly light exposed sediments (Lang and Wagner, 1997). Most samples passed the plateau test, which is a necessary but not sufficient indicator that the luminescence clock was fully reset at deposition time.

As it was known that these fluvial samples came from an environment that is prone to incomplete resetting, it was also tried to analyse the data by the 'differential partial bleach technique', advocated by Singhvi and Lang, 1998. As we couldn't see significant improvements (compared within the 1 sigma error limits of the OSL ages), the results are not reported here. Single grain quartz dating, which could provide further insights into the depositional conditions (e.g. Olley et al., 1998; 1999) was not feasible because of the extremely low OSL intensity of the quartz grains, which generally is below the detection threshold of the Riso OSL reader even for small aliquots.

All doserates were calculated on the basis of low level gammaspectrometry measurements. The dry, ground and homogenised soil samples were encapsuled in airtight perspex containers and stored for at least 4 weeks. This procedure minimizes the loss of the shortlived noble gas ${ }^{222} \mathrm{Rn}$ and allows ${ }^{226} \mathrm{Ra}$ to reach equilibrium with its daughters ${ }^{214} \mathrm{~Pb}$ and ${ }^{214} \mathrm{Bi}$. The samples were counted using high resolution gamma spectrometry with an ultralow background CANBERRA broad energy Ge detector (50\% nominal efficiency) for a minimum time of $24 \mathrm{~h}$. The spectra were analysed using GENIE2000 software. The 
doserate calculation is based on the activity concentration of the nuclides ${ }^{40} \mathrm{~K},{ }^{208} \mathrm{Tl},{ }^{212} \mathrm{~Pb}$, ${ }^{228} \mathrm{Ac},{ }^{214} \mathrm{Bi},{ }^{214} \mathrm{~Pb},{ }^{226} \mathrm{Ra}$., using the conversion factors of Adamiec and Aitken (1998).

\subsection{3 ${ }^{14} \mathrm{C}$ and OSL-based terrace ages}

In this section, we summarise and interpret results of OSL and ${ }^{14} \mathrm{C}$ dating of terraces $\mathrm{B}$ and $\mathrm{E}$, displayed in Table 1 (additional OSL data in Tables C2-1 \& C2-2). The ${ }^{14} \mathrm{C}$ ages obtained from samples Whine 3 and Whine 6 were very young or modern suggesting the wood sample may be a root, and the charcoal sample collected from a charcoal-rich layer near the ground surface, may have been deposited during flooding onto terrace E long after its abandonment (see Appendix C3). These ${ }^{14} \mathrm{C}$ results are not discussed further in this paper. The OSL ages obtained for silts (Whine 1, Whine 2, Whine 4, Whine 5) overlying the gravel tread of terrace E range from $10.1 \pm 0.9 \mathrm{ka}(1 \sigma)$ to $33.5 \pm 3.0 \mathrm{ka}(1 \sigma)$ (Table 1). The four OSL ages obtained for silts (Wai-10a, Wai-10b, Wai-11a and Wai-11b) overlying the gravel tread of terrace B range from $7.4 \pm 0.6 \mathrm{ka}$ to $26.8 \pm 2.2 \mathrm{ka}$ (Table 1). An OSL age of $37.9 \pm 2.4 \mathrm{ka}$ was obtained for sand sample Wai-1b, below the gravel tread of terrace B (Table 1).

The above OSL results are generally older than the expected abandonment ages of terraces $\mathrm{B}$ and $\mathrm{E}$. We attribute this age overestimation to inadequate sunlight exposure of the mineral grains during fluvial deposition. The problem is probably caused by a very short sediment transport distance, which could be as low as a few hundreds of metres and likely in turbid water under dim daylight (or even at night time). Having not been exposed to sufficient light, the feldspar grains carry a remnant age lower or equal to their previous sedimentation age, which equates to the age of one of the surrounding older fluvial aggradation terraces where the grains are sourced by erosion. Sample Wai-11b (Table 1) was the only sample that significantly failed the plateau test, showing clear signs of partial bleaching. It must be noted that the plateau test can only detect insufficient bleaching if most grains in a sample have seen at least some light, though it wasn't enough to reset the OSL clock. In a grain mixture where some of the grains have seen plenty of light, and others none, the plateau test must fail even though we're still dealing with an age overestimation due to partial bleaching (Duller, 1994, Duller et al., 1995). We conclude that most of our samples fall in the latter category, and their ages are overestimates for the abandonment age of the terrace they were collected from. For example, sample Wai-11a yielded an age for terrace B that was almost twice the known age of the terrace A (Wang \& Grapes, 2007), and the ages obtained from ${ }^{14} \mathrm{C}$ samples also collected from terrace $\mathrm{E}$ were modern, despite ages between $10.1 \pm 0.9 \mathrm{ka}(1 \sigma)$ and $33.5 \pm 3.0 \mathrm{ka}(1 \sigma)$ being obtained for 
OSL samples from that same terrace (Table 1), supporting the likelihood that the OSL samples were incompletely bleached.

The OSL age of sample Wai-1b, $37.9 \pm 2.4 \mathrm{ka}(1 \sigma)$, is a maximum age for the end of the aggradation of the Waiohine terrace. The OSL age of sample Wai-10a collected from terrace $\mathrm{B}, 14.2 \pm 1.3 \mathrm{ka}(1 \sigma)$, provides a maximum age for the abandonment of terrace $\mathrm{B}$. This sample was taken from just above the gravel tread of terrace B, and thus was deposited soon after the abandonment of the gravel tread. Sample Wai-10b with an OSL age of $7.4 \pm 0.6 \mathrm{ka}(1 \sigma)$, was collected $\sim 50 \mathrm{~cm}$ above the gravel tread of terrace $\mathrm{B}$, and thus may underestimate the abandonment age of terrace B.

\subsubsection{Age of the Waiohine surface}

The Waiohine surface (our terrace A), or the equivalent surface elsewhere in New Zealand, has been only sparsely (and controversially) dated during the past 40 years (Table C4-1). Age estimates for this surface range from $\sim 5 \mathrm{ka}$ to $30 \mathrm{ka}$ (Table C4-1). The debate over the Waiohine surface age is largely based on the identification and/or correlation of the Waiohine (or equivalent) surface across different parts of the North Island, and the different methods used to date the surface. Initial estimates for the age of the surface were based on its correlation with the last stadial of Last Glacial Maximum (e.g. Lensen \& Vella, 1971), while more recent estimates have used more direct methods of dating such as OSL and ${ }^{14} \mathrm{C}$ dating (e.g. Formento-Trigilio et al., 2002; Little et al., 2009; Wang \& Grapes, 2007). Many ages have been published for the youngest Ohakean terrace surface throughout the lower North Island, originally identified in the Rangitikei Basin, North Island (Milne, 1973), which was later correlated with the Waiohine surface in the Wairarapa Valley (e.g. Formento-Trigilio et al., 2002; Grapes, 1991). In this section, we summarise the results of three recent studies that have estimated the timing of Waiohine surface abandonment from OSL and ${ }^{14} \mathrm{C}$ samples collected in the Wairarapa Valley, and calculate the mean postglacial incision rate for the Waiohine River using the best constrained Waiohine surface age, and the amount of river downcutting.

Wang and Grapes (2007) presented eight OSL ages between $16.1 \pm 1.6 \mathrm{ka}$ and $10.0 \pm 0.9$ ka for the Waiohine surface, based on samples of inferred overbank silts/loess overlying Waiohine terrace gravels from six sites (Pigeon Bush, Tauwharenikau River, Waiohine River, Bucks Road, Matarawa Road and Burnetts Road) along the central and southern Wairarapa Fault. Three of those samples (MR1, WH1 and WH2) were collected near the Waiohine River terraces (Figures $2 \& 3$, Table 1). Sample MR1, dated at $10.0 \pm 0.8 \mathrm{ka}$, was 
collected from stony loess $0.60 \mathrm{~m}$ below the ground surface at a road cutting on Matarawa Road, north-east of the Waiohine River. Samples WH1 and WH2, dated at $13.0 \pm 0.9 \mathrm{ka}$ and $10.2 \pm 1.2 \mathrm{ka}$, respectively, were collected from a stony loess $0.65 \mathrm{~m}$ (WH1) and $0.77 \mathrm{~m}$ (WH2) below the ground surface on the north facing part of a cliff exposure of the Waiohine surface, east of the Waiohine River. These silts are likely to have accumulated on the Waiohine surface after its incision by the Waiohine River therefore their ages may underestimate the timing of abandonment of the Waiohine terrace tread.

Formento-Trigilio et al., (2002) report four OSL ages ranging from $5.12 \pm 0.37 \mathrm{ka}$ to 10.5 $\pm 1.2 \mathrm{ka}$ for loess coverbeds collected from Waiohine terrace surfaces in the Huangarua River Valley. They suggest that the Waiohine loess was deposited following Waiohine terrace abandonment, rather than being nearly synchronous with (i.e. immediately postdating) gravel deposition, and that the age of the Waiohine loess is not commensurate with terrace formation (as it is for the Rata and Porewa loess units). They estimate the Waiohine terrace tread was abandoned at $\sim 10-12 \mathrm{ka}$ (Formento-Trigilio et al., 2002).

Little et al., (2009) bracket the abandonment age of the Waiohine terrace using ${ }^{14} \mathrm{C}$ samples collected above and below the terrace tread at Cross Creek on the southern Wairarapa Fault, about $20 \mathrm{~km}$ south of the Waiohine River. Their ${ }^{14} \mathrm{C}$ age of $12,400 \pm 300 \mathrm{cal}$. Yrs. B.P. for peat interbedded within Waiohine terrace gravels provides a maximum age for the abandonment of the Waiohine terrace tread, and their ${ }^{14} \mathrm{C}$ age of 5,440 \pm 140 cal. Yrs. B.P. for wood obtained from peat above the top of the terrace gravels provides a minimum age. Little et al., (2009) interpret these ages to suggest a late Last Glacial Maximum terrace abandonment age of $\sim 12 \mathrm{ka}$, but possibly younger, and suggest the Waiohine terrace is ageequivalent to either the Ohakea 2 or Ohakea 3 terrace in the regional correlation scheme applied to the North Island, New Zealand (e.g., Litchfield \& Berryman, 2005).

Using the average elevation of terrace A on the downthrown side of the fault $(103.11 \pm$ $0.02 \mathrm{~m}(1 \sigma)$, and the elevation of the modern river bed (estimated as $88 \pm 2(1 \sigma) \mathrm{m}$ from a 260-S26 1:50,000 Carterton Topographic Map and the RTK GPS data obtained nearest the river), we calculate $15 \pm 2(1 \sigma) \mathrm{m}$ of downcutting since the abandonment of the Waiohine Surface. Together with an age of $11.5 \pm 2.5 \mathrm{ka}(1 \sigma)$ for the Waiohine surface, combined from the three OSL ages presented for that surface by Wang and Grapes (2007), this downcutting yields a mean postglacial incision rate for the Waiohine River of $1.4 \pm 0.5$ $\mathrm{mm} / \mathrm{yr}(1 \sigma)$ at this site (Figure 12). Litchfield and Berryman (2006) calculate postglacial fluvial incision rates for ten North Island rivers using the difference in elevation between 


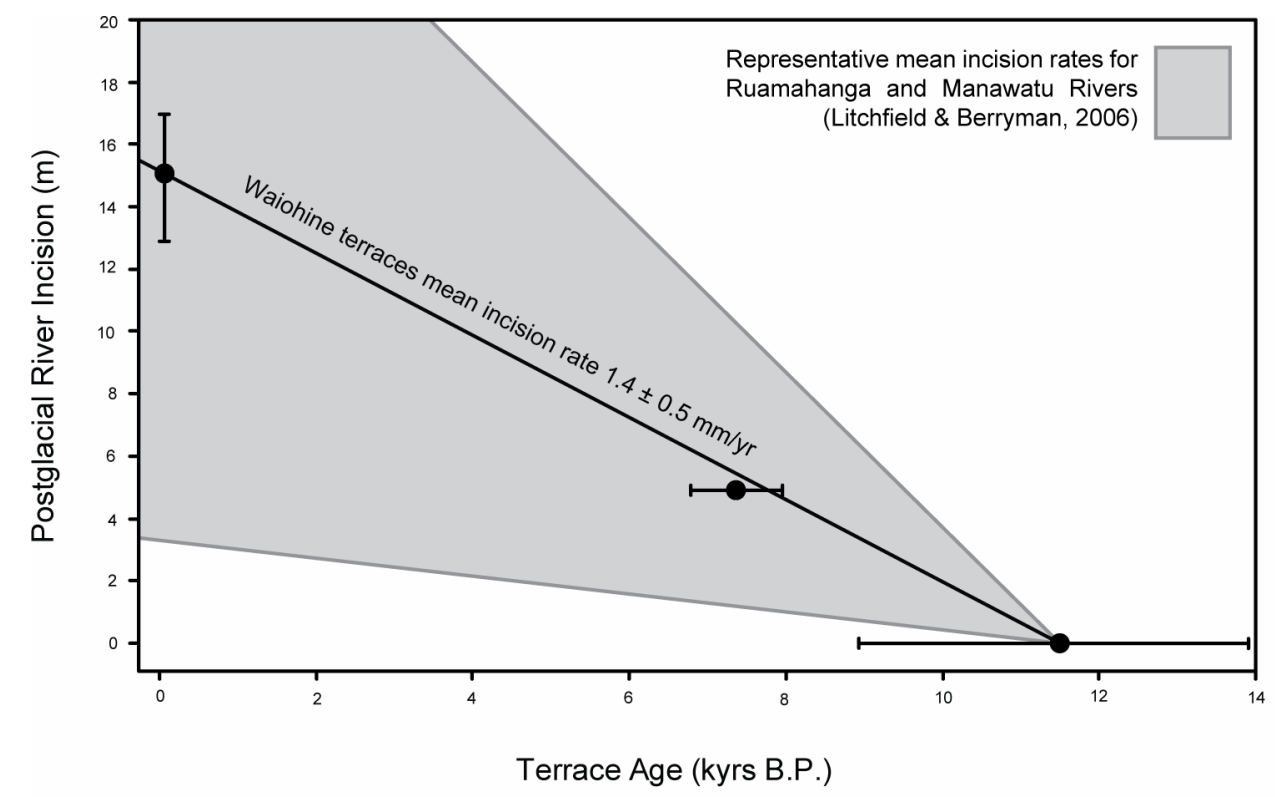

Figure 12. Mean postglacial river incision versus terrace age on the southeast side of the Wairarapa Fault at the Waiohine terraces. Incision is calculated with respect to terrace $A$ (Waiohine surface) for the downthrown side of the fault as it is assumed not to have undergone any tectonic uplift or subsidence (while the upthrown side has undergone tectonic uplift). The mean incision rate for the Waiohine River calculated from this study is $1.4 \pm 0.5 \mathrm{~mm} / \mathrm{yr}$. This incision rate falls within the range of postglacial fluvial incision rates calculated for ten North Island Rivers by Litchfield and Berryman (2006). The two rivers in the southern North Island nearest our study area (Ruamahanga and Manawatu Rivers) have mean incision rates of 0-3 $\mathrm{mm} / \mathrm{yr}$ and representative values of 0.3-2.5 mm/yr (Litchfield \& Berryman, 2006), also shown on the graph. Error bars are $1 \sigma(68 \%$ confidence). 
the LGM terrace tread and the present river bed, and an age of $18 \pm 2$ calendar ka for that LGM surface (Litchfield \& Berryman, 2006). Using an age of $11.5 \pm 2.5 \mathrm{ka}(1 \sigma)$ we recalculate incision rates for the Ruamahanga and Manawatu Rivers (nearest the Waiohine River) close to where those rivers exit the axial ranges, of 1.5-2.5 mm/yr, in good agreement with our incision rate calculated for the Waiohine River.

\subsection{Discussion}

\subsubsection{Interpreting progressive fault displacements at Waiohine River terraces under a complete riser trimming model}

Our study at the Waiohine terraces lends support to a model of complete riser trimming, both in map view and in vertical section (Figures $7 b \& 9 b)$. Support for this inference comes from: (1) the absence of any horizontal displacement in the modern river bank or of any vertical displacement in the modern river bed. This indicates that the 1855 scarp in the Waiohine River has been completely removed by the river (map view and vertical section) in the $\sim 100$ years since that earthquake; (2) the equivalence of the dextral displacements of riser $\mathrm{EF}$ and paleochannel $\mathrm{Ch} 2$ incised into terrace $\mathrm{F}$, immediately below riser EF (Table 2, Table B3-2, Figures 7b \& 11a), in accordance with Cowgill's (2007) second index which compares the similarity of riser and terrace tread displacements. This similarity suggests that riser EF only began recording displacement after its lower flanking terrace $\mathrm{F}$ became abandoned; (3) the absence of any risers that are curved in plan view in a sense that is consistent with the sense of slip on the fault, in accordance with the fourth index of Cowgill (2007). At the Waiohine terraces, none of the risers are sigmoidally curved in a dextral sense that would be consistent with the preservation of an incompletely trimmed dextral displacement; and (4) the differences in riser heights across the fault are equal to the vertical displacements of the risers lower bounding terraces across the fault, as would be expected for a case of complete scarp removal by the active river after every earthquake (e.g., Figure 9b).

\subsubsection{Single-event displacements on the central Wairarapa Fault at the Waiohine River}

The displacements measured at the Waiohine terraces are used to interpret the number earthquakes and the magnitude of co-seismic displacements occurring on the Wairarapa Fault since each terraces formation. The vertical displacement of terrace F $(1.30 \pm 0.02 \mathrm{~m}$ $(2 \sigma))$, and the dextral displacements recorded by riser EF $(11.4 \pm 1.7 \mathrm{~m}(2 \sigma))$, and Ch2 incised into terrace $\mathrm{F}(12.4 \pm 0.8 \mathrm{~m}(2 \sigma))$, are interpreted to represent co-seismic 
displacements that were generated during the $1855 \mathrm{M}_{\mathrm{w}}>8.1$ earthquake on the Wairarapa Fault. The uncertainty in the dextral displacement of $\mathrm{Ch} 2$ is smaller than that of riser EF (Table 2), and so the displacement of Ch2 is assumed to more faithfully record the 1855 dextral displacement at the Waiohine terraces.

The incremental vertical displacement between terraces $E$ and $F$ of $1.36 \pm 0.06 \mathrm{~m}(2 \sigma)$, and the incremental dextral displacement between riser DE and Ch2 of $9.7 \pm 1.7 \mathrm{~m}(2 \sigma)$, are interpreted to represent displacements that were generated during the penultimate earthquake on the Wairarapa Fault. The penultimate earthquake timing has most recently been narrowly constrained as $920-800$ cal. years B. P. through paleoseismic trenching studies on the southern Wairarapa Fault (Little et al., 2009). From the 1855 and penultimate single-event displacements, we infer a mean single-event dextral slip of $10.6 \pm$ $2.6 \mathrm{~m}(2 \sigma)$ and a mean single-event throw of $1.35 \pm 0.07 \mathrm{~m}(2 \sigma)$. The penultimate incremental displacements are similar to those attributed to the 1855 earthquake, suggesting that the last two events on the Wairarapa Fault had ruptures of comparable dimensions $(>120 \mathrm{~km})$ and magnitude $\left(\mathrm{M}_{\mathrm{w}} \sim 8\right)$ (Rodgers \& Little, 2006).

Given the above mean single-event dextral displacement, we infer that the dextral slip of riser $\mathrm{BC}(73.2 \pm 2.3 \mathrm{~m}(2 \sigma))$ resulted from an additional $4-6$ earthquakes prior to the penultimate earthquake. Considering the mean single-event throw and the vertical displacement of terrace D $(11.85 \pm 0.03 \mathrm{~m}(2 \sigma))$, we infer that it records slip from an additional 4-6 earthquakes that occurred after the abandonment of terrace D. Terrace C (vertically displaced by $12.99 \pm 0.03 \mathrm{~m}(2 \sigma)$ ) may record displacement as a result of one additional earthquake to those recorded by terrace $\mathrm{D}$, in the older time interval between terrace C and terrace D's abandonment. Given that dextral displacement of riser CD is within error of the displacement of riser $\mathrm{BC}$, it is possible that terraces $\mathrm{C}$ and $\mathrm{D}$ have experienced the same total number of earthquakes. If so, the apparent difference in their vertical offset would have to be attributed to the lateral displacement of paleotopography on terrace $\mathrm{C}$ to yield a locally higher scarp there. Considering the $\mathrm{H} / \mathrm{V}$ ratio for the Wairarapa Fault (section 2.9.3), it is unlikely that an earthquake on the Wairarapa Fault would result in $\sim 1.2 \mathrm{~m}$ of vertical displacement without any dextral displacement.

Using that same assumption of similar displacements to the mean single-event displacements in each earthquake, we infer that the vertical displacement of terrace $B$ and the dextral displacement of riser $\mathrm{AB}$ occurred as a result of $\sim 2$ more earthquakes than were 
experienced by terrace $\mathrm{C}$, and that terrace A experienced 2-3 more earthquakes than terrace B (Table 2).

\subsubsection{Horizontal to vertical slip ratios for the central Wairarapa Fault at the Waiohine River}

Based on the above cited set of progressive (incremental) displacements, we infer that the ratio of horizontal to vertical slip $(\mathrm{H} / \mathrm{V})$, on the Wairarapa Fault has ranged from 5.0 to 10.2 for the Waiohine River terraces (Figure 13), with a mean $\mathrm{H} / \mathrm{V}$ of $6.9 \pm 3.5(2 \sigma)$. H/V slip ratios were calculated for terrace $B$ relative to terrace $C(10.2)$, terrace $C$ relative to terrace $\mathrm{E}$ (5.0), terrace $\mathrm{E}$ relative to terrace $\mathrm{F}$ (7.2) and terrace F relative to the modern river channel (9.5). An $\mathrm{H} / \mathrm{V}$ slip ratio could not be calculated for terrace A (Waiohine surface) relative to terrace $\mathrm{B}$, as no dextral displacement can be measured for that terrace. The high $\mathrm{H} / \mathrm{V}$ slip ratios demonstrate the dominantly strike-slip nature of the Wairarapa Fault. Our range of $\mathrm{H} / \mathrm{V}$ slip ratios for the Waiohine terraces on the central part of the Wairarapa Fault is consistent with the $\mathrm{H} / \mathrm{V}$ slip ratio of $\sim 6-9$ reported for the southern part of the fault by Rodgers and Little (2006).

Although we did not identify any paleochannel incised into terrace A, we can estimate the displacement of terrace $\mathrm{A}$ since its abandonment by assuming that the average $\mathrm{H} / \mathrm{V}$ slip ratio for the Waiohine terraces is representative of the $\mathrm{H} / \mathrm{V}$ ratio for post-terrace $\mathrm{A}$ displacements. Using the average $\mathrm{H} / \mathrm{V}$ slip ratio for the Waiohine terraces of $6.9 \pm 3.5$ $(2 \sigma)$, and the cumulative vertical displacement for terrace $A$ of $19.67 \pm 0.09 \mathrm{~m}(2 \sigma)$, we infer a finite -dextral displacement of $129 \pm 18 \mathrm{~m}(2 \sigma)$ for terrace A (Figure 13).

\subsubsection{Late Quaternary slip rate for the central Wairarapa Fault at the Waiohine River}

Two terraces at the Waiohine River provide displacement and age data that can be used to determine the Late Quaternary slip rate on this central part of the Wairarapa Fault. According to a complete riser trimming model (justified for the Waiohine River in section 2.9.1 above), the displacement of a terrace riser is most precisely dated by the abandonment age of that risers lower bounding terrace. The dextral displacement of riser $\mathrm{AB}$ is precisely known, however the age of terrace $\mathrm{B}$ is poorly constrained from results of OSL dating in this study. The age of terrace A (Waiohine surface) is better constrained by OSL dates from Wang and Grapes (2007), however the displacement for this terrace was based on an inference from the displacement of terrace $B$ and the average $H / V$ ratio for the terraces (section 2.9.3). 


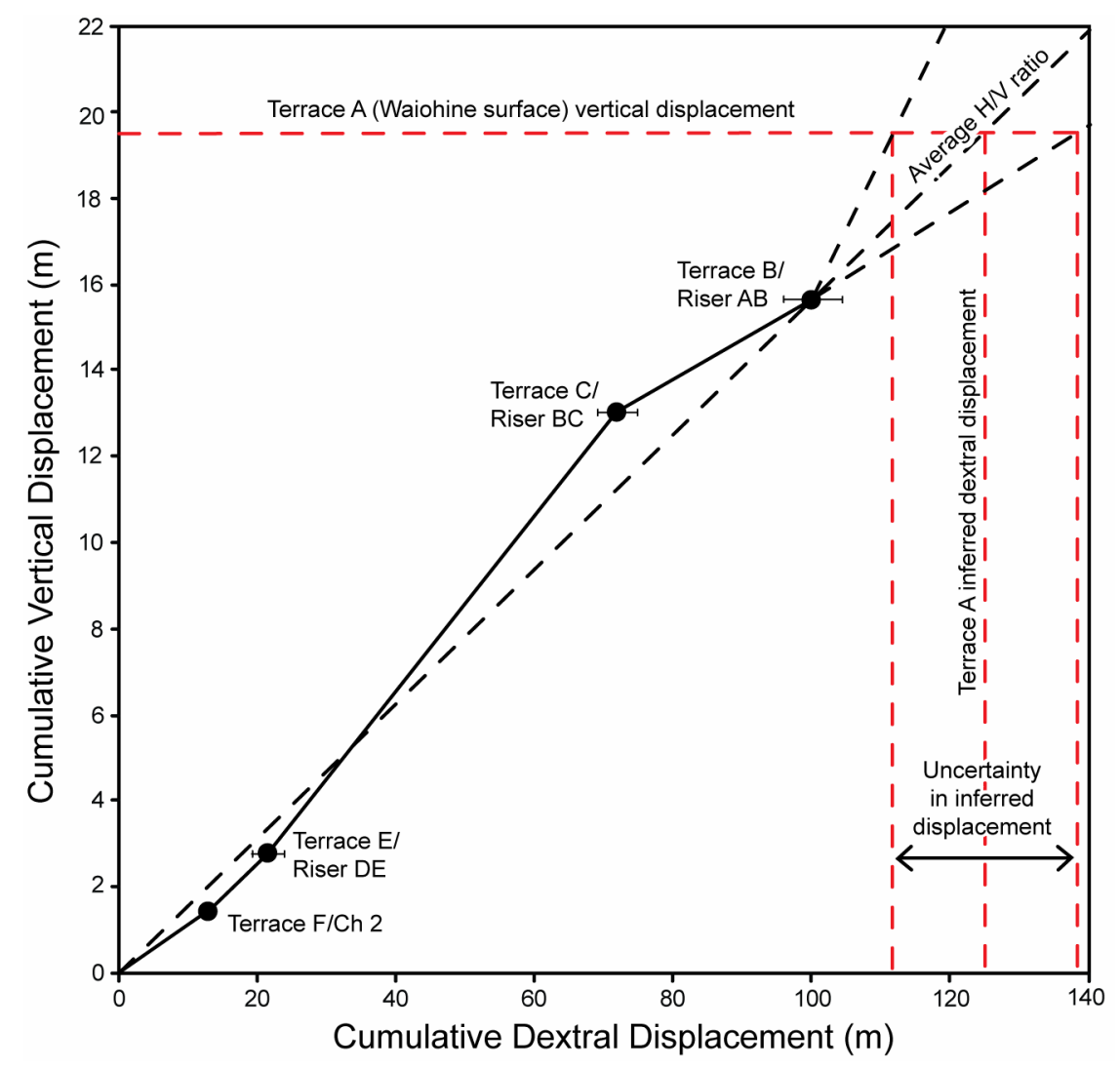

Figure 13. Cumulative vertical displacement versus cumulative dextral displacement across the Wairarapa Fault at the Waiohine terraces. The slope of each graph segment indicates the incremental $\mathrm{H} / \mathrm{V}$ slip ratio for each terrace. As described in section 2.7.1, the $H / \mathrm{V}$ ratio for terrace $D /$ riser $C D$ is not calculated. Error bars are $2 \sigma$ (95\% confidence), error bars for vertical displacements are too small to be shown. The average $\mathrm{H} / \mathrm{V}$ ratio for the Waiohine terraces is $6.9 \pm 3.5(2 \sigma)$. The cumulative vertical displacement for terrace A (Waiohine surface) is $19.67 \pm$ $0.09 \mathrm{~m}(2 \sigma)$. If this is projected across to intersect the average $\mathrm{H} / \mathrm{V}$ ratio projection, one can predict a cumulative dextral displacement for terrace $A$ of $129 \pm 18 \mathrm{~m} \mathrm{(2 \sigma )}$. 
We calculate a new minimum Late Quaternary dextral slip rate of $7.2 \pm 0.8 \mathrm{~mm} / \mathrm{yr}(1 \sigma)$ (Figure 14), from the cumulative displacement of riser AB, $101.1 \pm 3.4 \mathrm{~m}(2 \sigma)$, and the OSL age obtained for silt just above the gravel tread of terrace B, $14.2 \pm 1.3 \mathrm{ka}(1 \sigma)$. This is the most robust slip rate estimate for this central part of the Wairarapa Fault. The vertical displacement of terrace B is $15.74 \pm 0.04 \mathrm{~m}(2 \sigma)$. Combined with our maximum age for terrace B, this displacement implies a minimum Late Quaternary vertical slip rate of $1.1 \pm$ $0.1 \mathrm{~mm} / \mathrm{yr}(1 \sigma)$ (Figure 14).

Using our inferred dextral displacement for terrace A, $129 \pm 18 \mathrm{~m}(2 \sigma)$, and the age we assign to terrace A by combining the three OSL ages obtained for silts deposited on that surface in the Waiohine River area (Wang \& Grapes, 2007), $11.5 \pm 2.5 \mathrm{ka}(1 \sigma)$, we calculate a Late Quaternary dextral slip rate of $12.0 \pm 3.5 \mathrm{~mm} / \mathrm{yr}(1 \sigma)$ (Figure 14). Assuming a relative convergence rate of $\sim 39 \mathrm{~mm} / \mathrm{yr}$ along an azimuth of $\sim 261^{\circ}$ for the Pacific plate relative to the Australian plate (NUVEL-1A of De Mets et al., 1990; 1994), our Late Quaternary dextral slip rate at the Waiohine River suggests that the central part of the Wairarapa Fault accommodates $30-40 \%$ of the margin parallel component of Pacific plate motion, a much greater proportion than any other fault in the NIDFB.

\subsubsection{Variation in single-event dextral displacements on the Wairarapa Fault}

A number of recent studies have quantified single-event dextral displacements for the most recent one or two events along the Wairarapa Fault (e.g., Rodgers \& Little, 2007; Schermer et al., 2004; Van Dissen \& Berryman, 1996; Villamor et al., 2008). By comparing our dextral single-event displacements for the $1855(12.4 \pm 0.8 \mathrm{~m}(2 \sigma))$ and penultimate $(9.7 \pm 1.7 \mathrm{~m}$ $(2 \sigma))$ earthquakes for the central Wairarapa Fault at the Waiohine River with estimates from elsewhere along the fault, we observe a clear decrease in single-event displacements northwards along the Wairarapa Fault (Figure 15).

Rodgers and Little (2006) measured dextral single-event displacements for the 1855 and penultimate earthquakes on the southern Wairarapa Fault (Figure 15). The average dextral single-event displacements on the southern Wairarapa Fault, combining measurements from both single-strand and double-strand (slip distributed over two closely-spaced fault strands) parts of the fault are $15.5 \pm 1.4 \mathrm{~m}$ for the 1855 earthquake, and $13.9 \pm 0.6 \mathrm{~m}$ for the penultimate earthquake (Rodgers \& Little, 2006). A comparison between the southern Wairarapa Fault single-event displacements, and those measured at Waiohine River on the central Wairarapa Fault suggests a 10-30 \% northward reduction in co-seismic slip. 


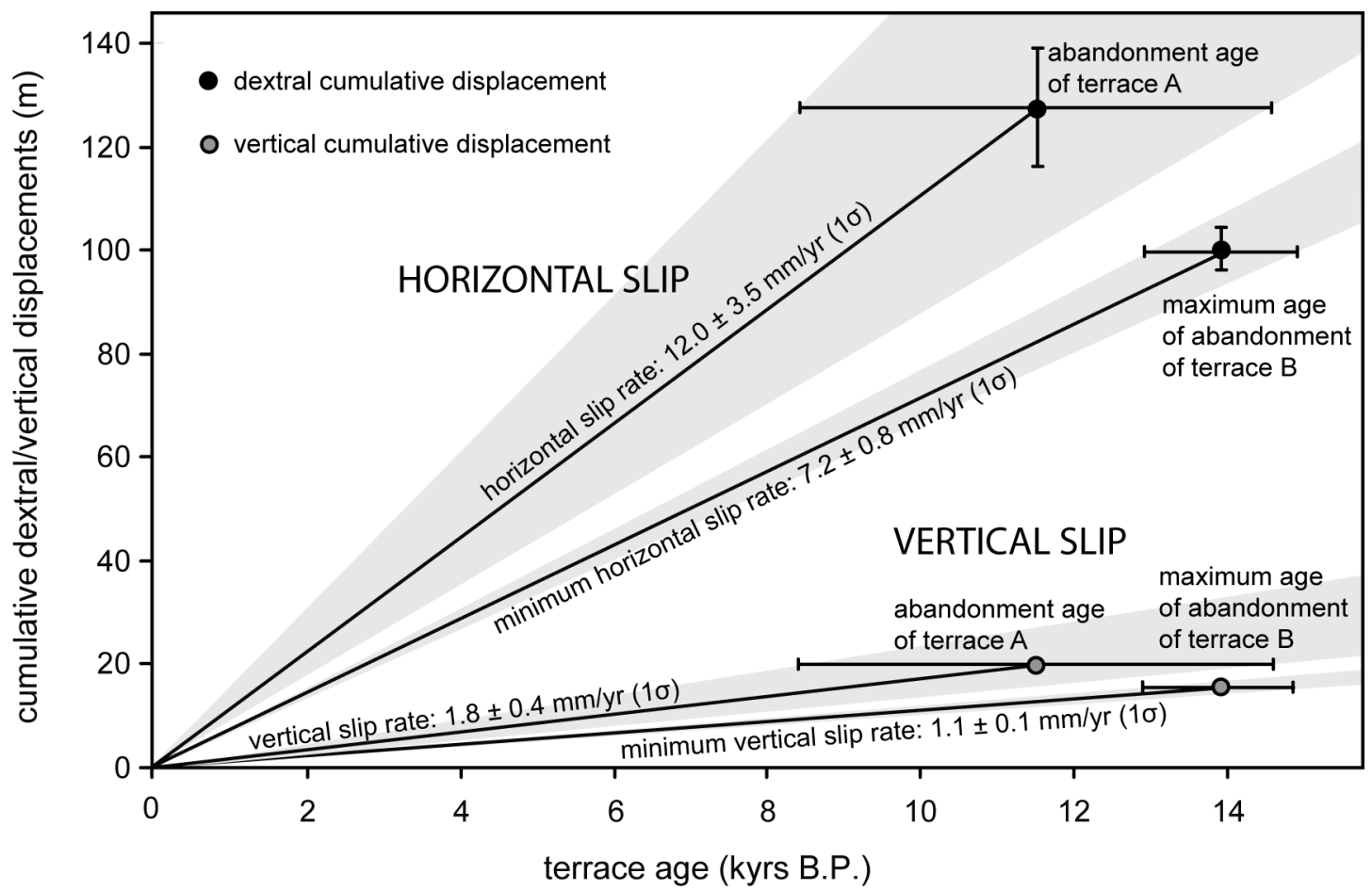

Figure 14. Cumulative dextral and vertical displacements across the Wairarapa Fault versus terrace age for terraces $A$ and $B$ at Waiohine River. Black dots are dextral displacements and grey dots are vertical displacements. Error bars are $1 \sigma$ (68\% confidence). Errors for vertical cumulative displacements are too small for the scale of this graph. For a description of how the age range for terrace $A$ was determined, see section 2.8.4. 
At Tauwharenikau River on the central Wairarapa Fault, $\sim 4 \mathrm{~km}$ southwest of the Waiohine River, Rodgers and Little (2006) measured dextral displacements of two paleochannels and a terrace riser on two closely spaced fault strands (Figure 15). The combined dextral displacement on these two strands is $24.4 \pm 2.5 \mathrm{~m}$, interpreted as slip that occurred during the last two earthquakes on the Wairarapa Fault. From this, we infer a mean dextral slip per event of $12.2 \pm 1.25 \mathrm{~m}$, within error of the single-event displacements for the two most recent earthquakes at Waiohine River.

Single-event displacements for the 1855 earthquake on the northern Wairarapa Fault (north of where the Carterton, Masterton and Mokonui Faults branch eastward off the Wairarapa Fault) are at least $10 \%$ smaller than at the Waiohine River. At Kopuaranga River (Figure 15) $\sim 35 \mathrm{~km}$ northeast of the Waiohine River, Villamor et al., (2008) attribute a displacement of $\sim 9.6 \mathrm{~m}$ to the 1855 earthquake. They suggest this measurement could include displacement from the past two earthquakes if other displacements of streams in the area of $\sim 4.5 \mathrm{~m}$ are statistically representative of the lower displacement value for the 1855 earthquake in this area (Villamor et al., 2008), which implies up to a $50 \%$ decrease in 1855 co-seismic displacements northward from Waiohine River.

Schermer et al., (2004) interpret the time of the most recent earthquake on the Alfredton Fault to be 1855 , implying that this earthquake rupture propagated across at $\sim 6 \mathrm{~km}$ wide right step, the Dreyers Rock Fault Zone (Schermer et al., 2004) (Figure 15). They report 1855 single-event dextral displacements ranging from 4 to $7 \mathrm{~m}$ on the Alfredton Fault (Schermer et al., 2004), implying a 40-70\% decrease in co-seismic slip from Waiohine River on the Wairarapa Fault to the Alfredton Fault in the 1855 earthquake (Figure 15).

\subsubsection{Variation in Late Quaternary dextral slip rate on the Wairarapa Fault}

Recent studies have placed constraints on the Late Quaternary slip rates for different sections of the Wairarapa Fault (e.g., Van Dissen \& Berryman, 1996; Villamor et al., 2008; Schermer et al., 2004). Villamor et al. (2008) proposed a northward decrease in Late Quaternary slip rate along the Wairarapa Fault. By comparing our new slip rate estimates for the central Wairarapa Fault at the Waiohine River with slip rates elsewhere along the fault, we investigate the proposed along-strike variation in dextral slip rate (Figure 15).

Little et al., (2009) calculate a Late Quaternary dextral slip rate for the southern Wairarapa Fault of $12 \pm 3 \mathrm{~mm} / \mathrm{yr}$, from the recently revised earthquake recurrence interval they estimated from paleoseismic trenching studies on the southern Wairarapa Fault of $1230 \pm$ 
190 years (Little et al., in 2009) and the mean single-event displacement of 13-16 m (Rodgers \& Little, 2006) on the southern Wairarapa Fault. Their southern Wairarapa Fault slip rate is indistinguishable from our central Wairarapa Fault slip rate at Waiohine River.

On the northern Wairarapa Fault, slip rates have recently been determined at three sites. At Tea Creek Road (Figure 15), just north of the intersection with the Mokonui Fault and 17 km northeast of the Waiohine River, Van Dissen \& Berryman (1996) report a dextral slip rate of $6.2 \pm 0.3 \mathrm{~mm} / \mathrm{yr}$ for the Wairarapa Fault. This slip rate most likely represents a minimum, as it is calculated on a section of the fault that forms a minor releasing bend where a reduction in lateral displacement may be compensated by an increase in vertical displacement (Van Dissen \& Berryman, 1996). Villamor et al., (2008) calculate dextral slip rates of $<7.9 \pm 1.8 \mathrm{~mm} / \mathrm{yr}$ at Kopuaranga River and $>1.4 \pm 0.2 \mathrm{~mm} / \mathrm{yr}$ at Ruamahanga River (Figure 15), 35 and $\sim 32 \mathrm{~km}$ northeast of the Waiohine River, respectively. The large variability in these northern Wairarapa Fault slip rate estimates place them within error of our slip rate at Waiohine River, however the maximum slip rate estimate $(7.9 \pm 1.8$ $\mathrm{mm} / \mathrm{yr}$ ) on the northern Wairarapa Fault is almost the same as the minimum slip rate estimate at Waiohine River $(7.2 \pm 0.8 \mathrm{~mm} / \mathrm{yr})$, and the maximum northern Wairarapa Fault slip rate is up to $50 \%$ smaller than central Wairarapa Fault slip rate, suggesting that slip rate does decrease northwards between the central and northern sections of the fault.

Schermer et al., (2004) report slip rates of $\sim 3 \mathrm{~mm} / \mathrm{yr}$ for the Alfredton Fault and 1.3-2 $\mathrm{mm} / \mathrm{yr}$ for the Saunders Road Fault (Figure 15), in the Dreyers Rock-Alfredton Fault system (eastern bifurcation of the Wairarapa Fault north of Mauriceville). The Alfredton Fault is speculated to have ruptured in 1855 (Schermer et al., 2004), but may not have ruptured during each Wairarapa Fault earthquake. Variations in slip rate beyond the Wairarapa Faults continuous trace are difficult to quantify, as different combinations of fault strands north of the Wairarapa Fault may have ruptured in Wairarapa Fault earthquakes, or independently.

\subsubsection{Accommodating northward-decreasing single-event displacements and slip rates on the Wairarapa Fault}

Variations in Late Quaternary slip rate along the Wairarapa Fault are difficult to distinguish owing to the small number of slip rate studies on the northern Wairarapa Fault; however, in this study a northward decrease in slip rate is apparent. We observe a much clearer northward decrease in co-seismic slip associated with the 1855 and penultimate earthquakes. A northward decrease in slip rate along the Wairarapa Fault could be the 


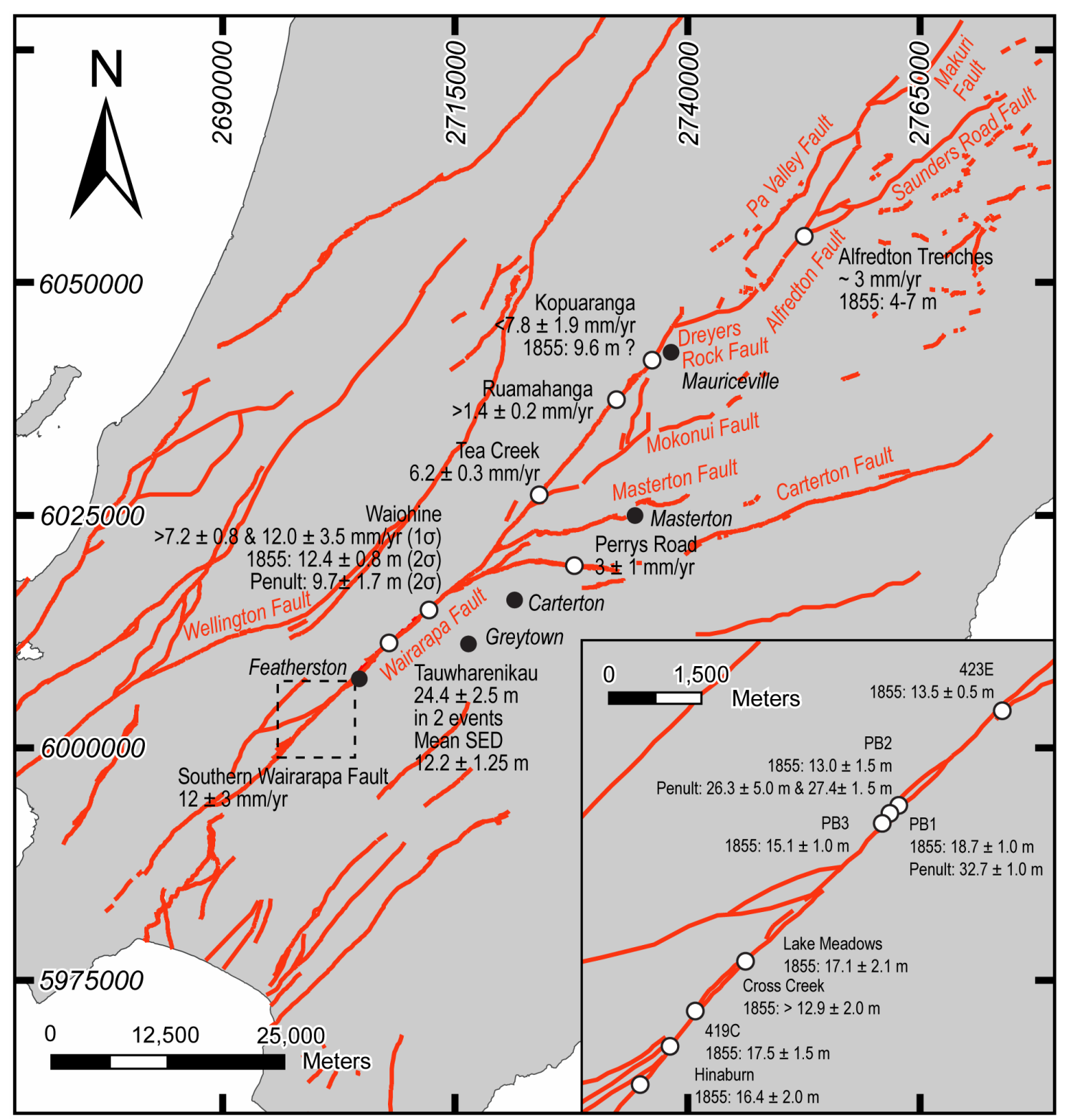

Figure 15. Variation in dextral slip rate and 1855 and penultimate earthquake dextal displacements along the Wairarapa Fault (Modified from Villamor et al., 2008). Active Faults are in red; white circles are study locations yielding slip rate and displacement data; black circles are main towns. Alfredton data are from Schermer et al., 2004; Kopuaranga and Ruamahanga data are from Villamor et al., 2008; Tea Creek data are from Van Dissen and Berryman, 1996, and Grapes and Wellman, 1988; Perrys Road data are from Zachariasen et al., 2000; Tauwharenikau data are from Rodgers and Little, 2006; Southern Wairarapa Fault data are from Little et al., 2009. Dashed box denotes area of inset. Inset: 1855 and penultimate earthquake displacements on the southern Wairarapa Fault, data are from Rodgers and Little, 2006. 
result of a decrease in magnitude of co-seismic slip northward along the fault, assuming that a similar length of fault ruptures during each earthquake, and/or different sections of the fault rupturing in different earthquakes, with more ruptures occurring on the southern section of the fault (Villamor et al., 2008).

From this study, it is evident that a northward decrease in single-event displacements would certainly provide a mechanism for accommodating a northward decrease in Late Quaternary slip rate on the Wairarapa Fault, at least during the 1855 earthquake, and likely the penultimate earthquake. The greatest (up to $50 \%$ ) decrease in 1855 single-event displacement on the Wairarapa Fault occurs across the section of fault where the Carterton, Masterton and Mokonui Faults branch eastward. Presumably, the missing dextral slip on the northern part of the fault has been accommodated by ruptures on one or a combination of these oblique-slip splay faults during great Wairarapa Fault earthquakes.

The Carterton Fault is the best characterised of the three splays, with a Late Quaternary dextral slip rate of $>2-4 \mathrm{~mm} / \mathrm{yr}$ (Villamor et al., 2008; Zachariasen et al., 2000). The dextral slip rates on the Masterton and Mokonui Faults have proven difficult to constrain due to a lack of displaced surface features and an unknown H/V slip ratio (Langridge et al., 2005; Villamor et al., 2008; Zachariasen et al., 2000). Kinematic modelling of tectonic block rotations using GPS velocities, earthquake slip vectors and geological fault slip rates in the North Island, suggest a combined dextral slip rate of $\sim 5 \mathrm{~mm} / \mathrm{yr}$ for the Carterton, Masterton and Mokonui Faults (Villamor et al., 2008; Wallace et al., 2004).

If these eastern splay faults do have a role in the transfer of deformation from the Wairarapa Fault, two observations should be evident; a distinct decrease in slip rate north of each splay fault intersection with the Wairarapa Fault (particularly north of the intersection with the Carterton Fault, which has the highest dextral slip rate of the three splays) and; a greater number of earthquakes in the paleoseismic record for the southern section of the Wairarapa Fault than its northern section. More paleoseismic investigations are needed to address these subjects.

\subsection{Conclusions}

New fault displacement and age data collected in this study at the Wairarapa Fault in the Waiohine River area provides new insights into the geomorphic expression and rate of 
deformation along this active strike-slip fault. Our findings are summarised by the following conclusions.

(1) A model of complete riser trimming is most appropriate for the Waiohine River terraces (based on similar offset of paleochannels and adjacent risers). From this, we infer that a riser begins recording displacement when its lower bounding terrace tread is abandoned. The most appropriate trimming model for any flight of displaced river terraces should be determined from a comparison between paleochannel and riser displacements. A comparison between riser displacements and the difference in terrace widths across the fault cannot be used to distinguish between trimming models.

(2) Based on the age and inferred displacement of terrace A, the Late Quaternary dextral slip rate for this part of the central Wairarapa Fault is $12.0 \pm 3.5 \mathrm{~mm} / \mathrm{yr}$ $(1 \sigma)$. Moreover, from the displacement and maximum age for terrace $\mathrm{B}$, we find a minimum slip rate of $7.2 \pm 0.8 \mathrm{~mm} / \mathrm{yr}(1 \sigma)$. The ratio of horizontal to vertical slip ranges from 5.0 to 10.2 for the Waiohine River terraces, with an average of $6.9 \pm$ $3.5(2 \sigma)$.

(3) The magnitudes of the inferred 1855 (smallest displacement) and penultimate (nextsmallest displacement) single-event displacements at the Waiohine terraces are 12.4 $\pm 0.8 \mathrm{~m}(2 \sigma)$ and $9.7 \pm 1.7 \mathrm{~m}(2 \sigma)$, respectively, implying a mean single-event dextral displacement of $10.6 \pm 2.6 \mathrm{~m}(2 \sigma)$ for the last two earthquakes on the Wairarapa Fault.

(4) Variations in Late Quaternary dextral slip rate were difficult to quantify, however a northward decrease in slip rate was apparent. The co-seismic dextral displacement for the 1855 and penultimate earthquakes on the Wairarapa Fault decreased northward by $10-30 \%$ from the southern section of the fault to the central section near Waiohine River (strike distance of $15-20 \mathrm{~km}$ ), and the 1855 co-seismic displacement decreased by $10-50 \%$ from the central section to the northern section (strike distance of $\sim 35 \mathrm{~km}$ ). A similarity of this type of along-strike reduction in coseismic slip during repeated earthquakes may be responsible for the apparent northward decrease in the Late Quaternary dextral slip rate along the fault. Presumably, the missing dextral slip on the northern part of the fault has been 
shunted off onto one or a combination of the Carterton, Masterton and Mokonui Faults during great Wairarapa Fault earthquakes. 


\title{
3 Development of Deformational Bulges along the Active Strike-Slip Wairarapa Fault, New Zealand
}

\begin{abstract}
The Wairarapa Fault is a major active dextral strike-slip fault in the North Island of New Zealand. Its highly segmented surface trace cuts through the Last Glacial Maximum (LGM) "Waiohine" aggradation gravels, 100-400 m east of the Tararua and Rimutaka Range front. Rapid deposition of Waiohine gravels during the LGM overwhelmed the active Wairarapa Fault by $\sim 12 \mathrm{ka}$, burying its scarp and covering the underlying Cenozoic and Mesozoic 'basement' rock. Subsequently, the fault has displaced geomorphic features incised into the Waiohine surface laterally by $\sim 130 \mathrm{~m}$, and warped that surface into deformational bulges. In a sense, the Waiohine surface provides a "real-life" sand-box model from which we can observe the surface deformation of an actual unfaulted sedimentary overburden above a natural reverse-oblique strike-slip fault. Through a combination of aerial photographic studies and field mapping, we have mapped a central section of the Wairarapa Fault trace, including a series of deformational bulges associated with stepovers between segments of that fault. We collected detailed topographic data across two particularly well expressed pressure bulges using a Real-Time Kinematic (RTK) Global Positioning System (GPS), from which volume calculations were made. The currently active Wairarapa Fault is inferred to be an immature splay that has only recently $(<100-250 \mathrm{ka})$ propagated upward to its current trace from a northwest-dipping master fault at depth, perhaps in response to topographic loading of the ranges. The near surface Wairarapa Fault geometry is characterised by a hierarchy of en echelon fault segments. The longest (Type A) segments $(2-7 \mathrm{~km})$ are separated by the largest $(250-350 \mathrm{~m})$ fault stepover widths (associated with Type A bulges), and have fault convergence depths that we calculate to be $\sim 100-260 \mathrm{~m}$. Our data indicate that Type A segments converge into the main Wairarapa Fault well below the base of the Waiohine gravels (maximum of $\sim 30 \mathrm{~m}$ thick), and in basement. We infer that Type A faults and bulges began forming in basement rock prior to Waiohine gravel deposition. By contrast, the convergence depths for the much shorter Type B en echelon fault segments $(500 \mathrm{~m}$ to $>4 \mathrm{~km})$, separated by smaller stepover widths $(30-150 \mathrm{~m})$ and associated with Type B bulges, are calculated to be $\sim 1-18 \mathrm{~m}$. Type B fault segments are thus thought to converge into a single fault segment at or near the base of the Waiohine gravels, representing distributed deformation in the Waiohine gravels since their rapid deposition. The en echelon pattern of surface faulting resembles that predicted by analogue models of the deformation of a previously unfaulted, non-cohesive overburden above a strike-slip to oblique-slip basement fault. In the natural case of the Wairarapa Fault, however, the en echelon fault segments strike at a smaller angle $\left(2^{\circ}-18^{\circ}\right.$, average of $\left.\sim 6^{\circ}-7^{\circ}\right)$ to the average strike of the main fault at depth, and the Wairarapa Fault zone is much narrower $\left(350 \mathrm{~m}\right.$ wide), than is predicted by these analogue models (strike angle of $10^{\circ}-30^{\circ}$ and fault zone width of $1-2 \mathrm{~km}$ ). We interpret these differences to reflect the shallow fault convergence depths at the Wairarapa Fault in comparison to the thickly sedimented analogue models. The obliquity of convergence and the northwest dip of the Wairarapa Fault plane are reflected by the asymmetry of the surface structures along the fault, including the triangular shape of the pressure bulges in plan view, the across-strike asymmetry of the en echelon fault segments in profile, and the partitioning of slip components between the two fault strands bounding each pressure bulge.
\end{abstract}




\subsection{Introduction}

The segmented nature of active strike-slip fault traces and associated surface deformation have been well-documented; however, the mechanisms controlling such near surface fault expressions remain more poorly understood. Many authors have used sand or clay analogue deformation models to better understand the formation of en echelon fault segments in strike-slip faults, especially in the sedimentary cover above a single basement fault (e.g. Cloos, 1929; Naylor et al., 1986; Riedel, 1929; Wilcox et al., 1973). A related topic of analogue deformation modelling has been the formation of pressure bulges above bends or stepovers in the strike-slip basement fault (e.g. McClay \& Bonora, 2001; Richard et al., 1995). Natural occurrences of these discontinuous surface deformational features, however, are typically more complex than can be explained by these simple models, probably in large part owing to the wide range of boundary conditions applicable to the natural environment. For example, unlike the majority of analogue models, strike-slip faults in nature almost always accommodate oblique-slip, rather than pure strike-slip displacement. The influence of oblique convergence on the fault geometry is uncertain, and only a few analogue models have attempted to explain the surface deformation in obliquely convergent environments (e.g., Richard, 1991; Richard et al., 1995).

The Wairarapa Fault is a major active dextral strike-slip fault in the North Island of New Zealand that is one element of the obliquely convergent Pacific-Australia plate boundary. The highly segmented trace of this fault is especially clearly expressed at the surface because of the widespread distribution of the Late Quaternary fluvial gravel sequence termed the "Waiohine" gravels. The Waiohine surface at the top of the gravels is the aerially most extensive paleo-geomorphic surface in the Wairarapa Valley, formed by the coalescence of the alluvial fans of a series of large rivers during the Last Glacial Maximum (LGM) (Grapes, 1991). The influx of Waiohine gravels at this time, presumably overwhelmed the active Wairarapa Fault, burying its scarp and covering the underlying Cenozoic sediments and Mesozoic greywacke (collectively termed 'basement' in this paper). This burial was rapid enough to obliterate most geomorphic evidence of any fault displacements that occurred before deposition of those gravels (Lensen \& Vella, 1971). Subsequent fault displacements of geomorphic features incised into the Waiohine surface, and the warping of that surface into deformational bulges has taken place since the deposition of the gravels ( $\sim 12 \mathrm{ka})$. For this reason, the Waiohine surface, in a sense, provides a "real-life" sand-box model from which we can observe the surface deformation 
of an actual unfaulted sedimentary overburden above a natural reverse-oblique strike-slip fault.

Through a combination of field work and aerial photographic studies, we have mapped a central section of the Wairarapa Fault trace, a series of deformational bulges associated with stepovers on that fault, and a set of Late Quaternary landforms displaced by that structure. We collected detailed topographic data across two particularly well expressed pressure bulges using a Real-Time Kinematic (RTK) Global Positioning System (GPS). These data were used to resolve the shape and volume of these surface structures. In this paper, we will compare the near surface geometry of the fault segments and their bulges to the predictions and results of previously published analogue modelling studies. Our goal is to investigate the causes and mechanisms by which the observed surface deformation features along this active fault, especially its segmentation and the bulges, have developed. We ask several questions: Can the observed fault stepovers and pressure bulges in the surficial Waiohine gravels along the Wairarapa Fault be explained by distributed deformation of those previously undeformed gravels above a previously formed, discrete basement fault, similar to the boundary conditions in many of the analogue modelling studies? Or is the surface segmentation a reflection of deeper stepovers or bends penetrating well below the gravels and into the basement? Have all of the observed pressure bulges along the Wairarapa Fault formed in the same way, or do the mechanisms controlling their formation vary? From the volumetric data and our previous knowledge of the amount of slip accumulating on the fault since the deposition of the Waiohine gravels, we calculate the depths to which the bulges extend. Finally we refer to some of the most relevant analogue modelling studies, together with our field data to produce a new model of the near surface 3D geometry of the Wairarapa Fault.

\subsection{Tectonic Setting and the Wairarapa Fault}

New Zealand straddles the boundary between the Pacific and Australian plates, accommodating oblique subduction of oceanic crust along the Hikurangi margin in the North Island, and oblique continental collision in the South Island (Figure 16). In the southern North Island the $3 \mathrm{Myr}$ averaged relative convergence rate of the Pacific plate relative to the Australian plate is $\sim 39 \mathrm{~mm} / \mathrm{yr}$ along an azimuth of $\sim 261^{\circ}$ (NUVEL-1A of De Mets et al., 1990; 1994), calculated from seafloor spreading and earthquake slip direction data, while the present-day plate motion vector in the southern North Island, 


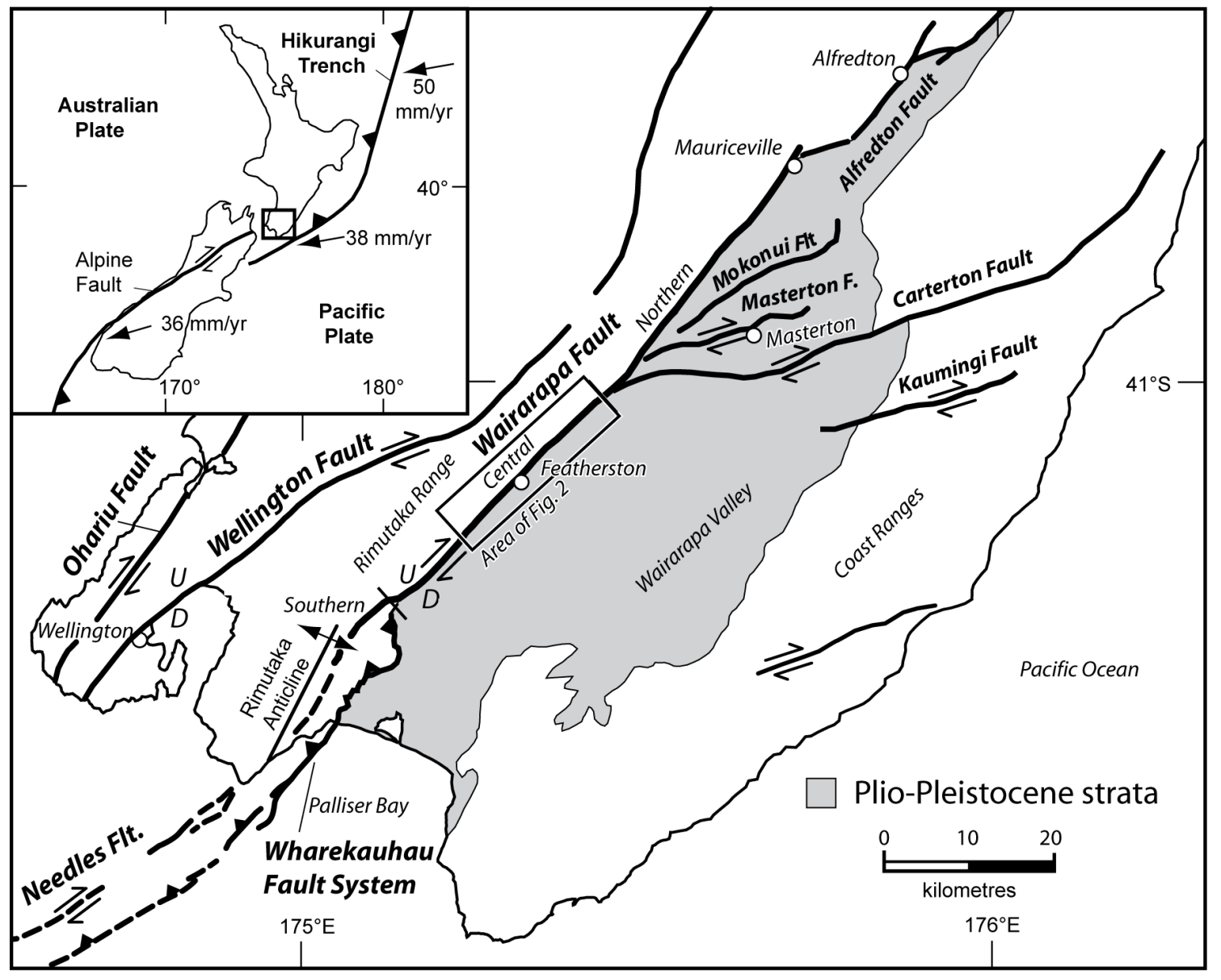

Figure 16. Major active faults in the lower North Island, New Zealand (modified from Little et al., 2009). Small open circles are main towns. Different sections of the Wairarapa Fault referred to in the text are labelled. Small box indicates the section of the central Wairarapa Fault that is the focus of this study (area of Figure 20). Inset: Tectonic setting of New Zealand, where plate motion directions are of Pacific relative to Australian Plate according to Nuvel 1a plate motion model of De Mets et al., (1990; 1994). 
calculated from the motion of GPS stations over an 11 year period, is $\sim 42 \mathrm{~mm} / \mathrm{yr}$ along an azimuth of $\sim 258^{\circ}$ (Beavan et al., 2002).

A small proportion (not more than $\sim 40 \%$ ) of the margin-perpendicular component of plate motion ( $\sim 22 \mathrm{~mm} / \mathrm{yr})$ is accommodated by shortening of the upper (Australian) plate through thrust faulting and related folding in the onshore and offshore parts of the plate, including in an offshore accretionary wedge that merges downwards into the subduction interface (Barnes et al., 1998; Barnes \& Mercier de Lepinay, 1997). A maximum of 3-8 $\mathrm{mm} / \mathrm{yr}$ of shortening has been inferred to be accommodated by slip on upper plate faults across the southern North Island since the Oligocene (Nicol et al., 2007), in part by the dip-slip component of motion on a series of dextral-oblique faults in the North Island, including the Wairarapa Fault (Figure 16). The margin-parallel component of plate motion is largely accommodated by slip on these NNE-striking active faults which are collectively referred to as the North Island Dextral Fault Belt (NIDFB) (Beanland, 1995; Berryman, 1990; Rodgers \& Little, 2006; Van Dissen \& Berryman, 1996; Van Dissen et al., 1992; Wang \& Grapes, 2007). At the surface these NIDFB faults typically dip steeply to the northwest, and have a small component of vertical slip commonly up to the northwest. Seismicity data suggest that these faults intersect the Hikurangi subduction megathrust at depths of 20-30 km beneath the southern North Island (e.g., Reyners, 1998).

The Wairarapa Fault is the most eastern of the active dextral-reverse faults in the NIDFB (Figure 16) and dips steeply to the northwest. It is interpreted to have been initiated in the Pliocene as a reverse fault, but to have evolved into an oblique strike-slip fault at $\sim 1-2 \mathrm{Ma}$ in response to clockwise vertical axis rotation of it and the rest of the Hikurangi forearc relative to the Pacific plate (Beanland, 1995; Beanland \& Haines, 1998; Kelsey et al., 1995). It most recently ruptured in an $\mathrm{M}_{\mathrm{w}}>8.1$ earthquake on 23 January 1855 over an onshore distance of $\sim 120 \mathrm{~km}$ (Rodgers \& Little, 2006). The dip of the Wairarapa Fault at the surface and at depth has been constrained by the results of three studies. Recent paleoseismic trenching at the Cross Creek pull-apart graben on the central-southern section of the fault constrained the fault dips at that site within several metres of the surface, for the two fault strands bounding the graben as $75^{\circ}-85^{\circ}$ towards each other (Little et al., 2009). Von Borstel and Ingham (2004) imaged the Wairarapa Fault at Tauwharenikau River using magnetotelluric sounding, with results suggesting the Wairarapa Fault may have a northwest dip of $\sim 80^{\circ}$ at depths between $\sim 1-3 \mathrm{~km}$. Hicks and Woodward (1978) model gravity profiles in the Wairarapa valley and find a near vertical dip for the Wairarapa Fault at its northern end, decreasing to as low as $15^{\circ}$ at its very southern onshore end. 
a) Map View

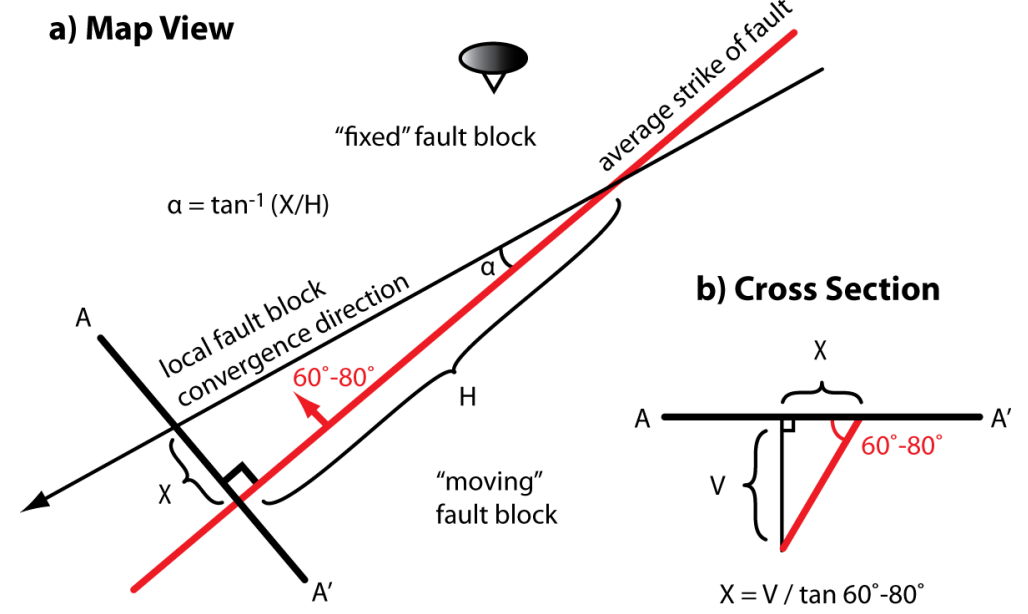

Figure 17. Calculating the local fault convergence angle at the Wairarapa Fault using a rigid fault displacement model. $\mathrm{H}$ and $\mathrm{V}$ are horizontal and vertical (throw) displacements across the fault, respectively. $X$ is the heave component of dip-slip displacement, calculated using trigonometry in a cross section perpendicular to the average strike of the fault. $\alpha$ is the angle between the local fault convergence direction (slip vector) and the average strike of the fault, also calculated using trigonometry. Using the average horizontal to vertical slip ratio from the Waiohine River terraces of $6.9 \pm 3.5$ (Chapter 2 of this thesis, and Carne et al., manuscript in prep), and assuming a northwest fault dip of $60^{\circ}-80^{\circ}$ (Hicks \& Woodward, 1978; Little et al., 2009; Von Borstel \& Ingham, 2004), a rigid fault displacement model yields a local fault convergence angle at the central Wairarapa Fault oriented between $1^{\circ}$ and $10^{\circ}$ clockwise (average of $3^{\circ}$ ) to the average strike of the fault. The $\mathrm{H} / \mathrm{V}$ slip ratio on the central-southern section of the fault, of 6-10, reported by Rodgers and Little (2006), implies a local fault convergence angle oriented between $1^{\circ}$ and $6^{\circ}$ clockwise (average of $3^{\circ}$ ) to the average strike of the fault. 
Assuming an average $\mathrm{H} / \mathrm{V}$ slip ratio of $6.9 \pm 3.5$ (Chapter 2 of this thesis, and Carne et al., manuscript in prep), and a fault dip of $60^{\circ}-80^{\circ}$ (Hicks \& Woodward, 1978; Little et al., 2009; Von Borstel \& Ingham, 2004), the fault slip vector at the Wairarapa Fault has a trend of $\sim 230^{\circ}$, oriented $\sim 1^{\circ}-10^{\circ}$ (average of $\sim 3^{\circ}$ ) clockwise of that faults strike, but $\sim 20^{\circ}-30^{\circ}$ anticlockwise to the Pacific-Australia plate motion (Figure 17), implying strong slip partitioning of oblique plate motion in the NIDFB.

\subsection{The Waiohine Aggradation Terrace}

The Waiohine aggradation gravels were formed by the coalescence of alluvial fans from Rivers draining the Tararua and Rimutaka Ranges (Waingawa, Waiohine, Tauwharenikau and Ruamahanga Rivers) during the LGM (Begg \& Johnston, 2000; Grapes, 1991). Carne et al., (Chapter 2 of this thesis, and manuscript in prep) summarise the previously published ${ }^{14} \mathrm{C}$ and OSL ages for the Waiohine surface, or the equivalent surface elsewhere in New Zealand. An age of $11.5 \pm 2.5 \mathrm{ka}(1 \sigma)$ is adopted for the Waiohine surface from the most recently published OSL age estimates of samples collected near the Wairarapa Fault (Wang \& Grapes, 2007; Chapter 2 of this thesis, and Carne et al., manuscript in prep).

Fault displacements of landforms on the Waiohine surface, and warping of that surface into deformational bulges must have occurred since the deposition of the gravels. The Waiohine surface, in a sense, provides a "real-life" sand-box model of surface deformation in a previously unfaulted sedimentary overburden above a reverse-oblique strike-slip fault, for which the displacement of that surface is known. Displacements of this surface are summarised by Carne et al., (Chapter 2 of this thesis, and manuscript in prep), and a dextral post-Waiohine surface displacement of $129 \pm 18 \mathrm{~m}(2 \sigma)$ has been measured at Waiohine River (Chapter 2 of this thesis, and Carne et al., manuscript in prep). This post-Waiohine surface dextral displacement is an important piece of information that we use in this study; in particular for the volume calculations described in section 3.7.2 for two deformational bulges that occur just southwest of the Waiohine River.

The thickness of the regionally extensive Waiohine aggradation gravels is poorly constrained and probably variable as a result of the scarp paleotopography that predated deposition of the gravels, and their fan-like morphology. The gravels have a gentle primary dip of up to $\sim 0.6^{\circ}$ to the southeast, and range in elevation from $120 \mathrm{~m}$ to $<20 \mathrm{~m}$ (asl), while relief across the fans ranges from $20 \mathrm{~m}$ to $60 \mathrm{~m}$. At the Waiohine River, Mesozoic greywacke is exposed in the river bed on the upthrown side of the centra; Wairarapa Fault. 
Using the average elevation of RTK GPS points collected on top of the Waiohine terrace (Appendices A1 \& A2) directly above the river, and the elevation of the river as determined from a topographic map, we calculate a maximum thickness for the gravels at this site of $\sim 23 \mathrm{~m}$. This is a maximum estimate for this site as greywacke could be exposed further up the cliff above the river. Waiohine gravels directly overlie Mesozoic greywacke at this location, suggesting that the original cover of Cenozoic sediments had been uplifted and completely eroded before deposition of the Waiohine gravels. The gravels are likely to be thicker on the downthrown side. On the northern side of the Waiohine River, the Waiohine surface is the oldest and highest terrace in a flight of progressively displaced degradational terraces. Here, the steep fault scarp reaches a maximum height of $\sim 20 \mathrm{~m}$, and no basement rock is exposed, however it may be obscured by material eroded from higher up the scarp and deposited at its base.

At Pigeon Bush, on the southern part of the Wairarapa Fault, Rodgers and Little (2006) report a sharply defined scarp with a height of $\sim 8-9 \mathrm{~m}$ that exposes only Waiohine terrace gravels, and no basement rock. Here the Waiohine surface is back-tilted to the southwest on the upthrown side of the fault by $\sim 5^{\circ}$, on the limb of a step-over related anticlinal bulge cresting to the northeast (Rodgers \& Little, 2006). Detailed mapping and surveying at the south coast by Schermer et al., (in review), suggests the thickness of the Waiohine gravels at the south coast within the Wharekauhau Fault system is highly variable, but no thicker than $\sim 50 \mathrm{~m}$, and strongly influenced by an earlier scarp generated along the Wharekauhau Thrust, an element of the Wharekauhau Fault System at the southern end of the Wairarapa Fault (Figure 16).

\subsection{Formation of En Echelon Faults and Deformational Bulges along Strike-Slip Faults}

\subsubsection{En echelon nature of strike-slip faults}

When strike-slip faults initiate in natural and experimental settings, they are often highly segmented, consisting of discontinuous en echelon fault segments that form a stepped arrangement of approximately parallel faults oriented obliquely with respect to the average strike of the fault (Cloos, 1928; Riedel, 1929; Tchalenko, 1970; Wilcox et al., 1973). Dextral faults generate left-stepping en echelon arrangements and sinistral faults generate rightstepping en echelon arrangements, where the stepping is of the sense that allows a small component of tensile opening of the faults (Yeats, Sieh \& Allen, 1997). Types of secondary 
or incipient faults that are typically described in strike-slip fault zones in natural and experimental settings include Riedel (R) faults (synthetic strike-slip faults), conjugate Riedel (R') faults (antithetic strike-slip faults), P-faults (secondary synthetic strike-slip faults) and Y-faults (Figure 18) (Naylor et al., 1986; Sylvester, 1988, Wilcox et al., 1973).

For pure strike-slip (or simple shear) cases, R-faults typically form at an angle of $10^{\circ}-30^{\circ}$ to the average strike of the fault or shear zone (Figure 18), and R'-faults typically form at an angle of $70^{\circ}-90^{\circ}$ (Figure 18) (Wilcox et al., 1973). During strike-slip simple shear of an elastic-frictional plastic, isotropic material, the maximum compressive stress, $\sigma_{1}$, attains an orientation of $\sim 45^{\circ}$ to the strike of the fault or shear zone (Mandl et al., 1977). Previously intact elastic-frictional plastic materials that fail according to ideal Coulomb-Mohr behaviour will generate faults that are oriented at $45^{\circ}-\varphi / 2$ to $\sigma_{1}$, where $\varphi$ is the internal angle of friction of the material (Naylor et al., 1986). R-faults are usually viewed as being near ideally oriented Coulomb-Mohr faults, at least at the free surface, where $\sigma_{1}$ and $\sigma_{3}$ are horizontal and parallel to the ground surface, and $\sigma_{2}$ is vertical (Naylor et al., 1986). Densely packed sand has an internal angle of friction of $35^{\circ}-40^{\circ}$, which implies that the angle between a pure strike-slip fault and $\sigma_{1}$ should be $25^{\circ}-28^{\circ}$, and that an R-fault should therefore strike $17^{\circ}-20^{\circ}$ to the basement fault (Figure 18) (Naylor et al., 1986). The conjugate R'-faults form on the opposite side of $\sigma_{1}$, to make an angle of $70^{\circ}-73^{\circ}$ to the strike-slip fault (Figure 18) (Wilcox et al., 1973). Because the R'-faults are poorly oriented for kinematic displacements required by the main strike-slip zone, they are less common than R-faults, and often do not form (Wilcox et al., 1973). P-faults are thought to form as a kinematic linkage between adjacent R-faults (Figure 18). P-faults slip in a synthetic sense to the main fault or shear zone and strike in the opposite direction than the R-faults do, with respect to the average strike of the fault or shear zone (Figure 18). Y-faults are defined as faults that form approximately parallel to the strike of the basement fault or shear zone (Wilcox et al., 1973).

\subsubsection{Deformation at fault bends and stepovers}

Strike-slip fault zones are rarely defined by a single, straight or smoothly curved fault trace, more often exhibiting deviations such as fault bends or stepovers. Bends in a fault trace are offset areas where bounding strike-slip faults are continuously linked and curved across the offset, whereas stepovers are defined as unfaulted or unconnected zones of slip transfer between overstepping, but distinctly separate and subparallel strike-slip faults (Cunningham \& Mann, 2007). Fault bends and stepovers create dilational strains in the horizontal plane that result in vertical components of deformation and the formation of secondary 
structures (e.g., Yeats, Sieh \& Allen, 1997). Bends and stepovers can be classified as restraining or releasing depending if they accommodate local contraction or extension, respectively (Figure 19). On a dextral strike-slip fault, a left stepover or bend will produce contraction, while a right stepover will produce extension (Figure 19). The opposite is true of a sinistral strike-slip fault (Figure 19). Restraining bends/stepovers are predicted to be sites of topographic uplift, producing elongate, individual massifs with anomalously high topographic elevations (Figure 19), while releasing bends/stepovers are likely sites of subsidence producing pull-apart basins (Cunningham \& Mann, 2007). The most important factor governing uplift or subsidence along a steeply-dipping strike-slip fault is the curved geometry of the fault surface, and its depth extent, relative to its slip vector, because this determines whether local convergence or divergence will occur (Sylvester, 1988). In any case where the slip vector is not within the plane of the principal strike-slip fault that separates them, extensional or contractional secondary structures can be expected.

The nature and geometry of deformation at fault stepovers is largely dependent on the geometry of strike-slip faults at both the initial and successive stages of faulting (Aydin \& Nur, 1985). Large amounts of lateral slip promote greater vertical relief and prominence of P-faults between adjacent $\mathrm{R}$-faults, due to the increasing severity of dilational strains in these stepover areas, and increasing fault propagation and linkage along strike (Yeats, Sieh \& Allen, 1997). Strike-slip ruptures are often characterised by jumbled zones of R-faults, Pfaults, principal displacement faults, and auxiliary fissures and folds, resembling large “mole-tracks" (Yeats, Sieh \& Allen, 1997). Large "mole-tracks" are commonly still recognisable decades after their formation (e.g. Armijo et al., 1989).

\subsubsection{Origin of fault bends and stepovers}

The origin and evolution of strike-slip fault bends and stepovers are probably controlled by many factors including fault geometry and fault reactivation, slip magnitude, stress field variations, and the feedback between climate, topography, faulting and thermal history (Cunningham \& Mann, 2007). Mechanisms that may produce stepovers and control the sense of stepover include the bending or rotation of initially straight fault segments, faulting within an inherited or reactivated weak zone that strikes obliquely to the rest of the fault zone, shear reactivation of pre-existing extensional fractures, and change in the orientation of the stresses during the fault propagation process resulting from fault interaction, or as a result of pore fluid pressure variations (Aydin \& Nur, 1985). 


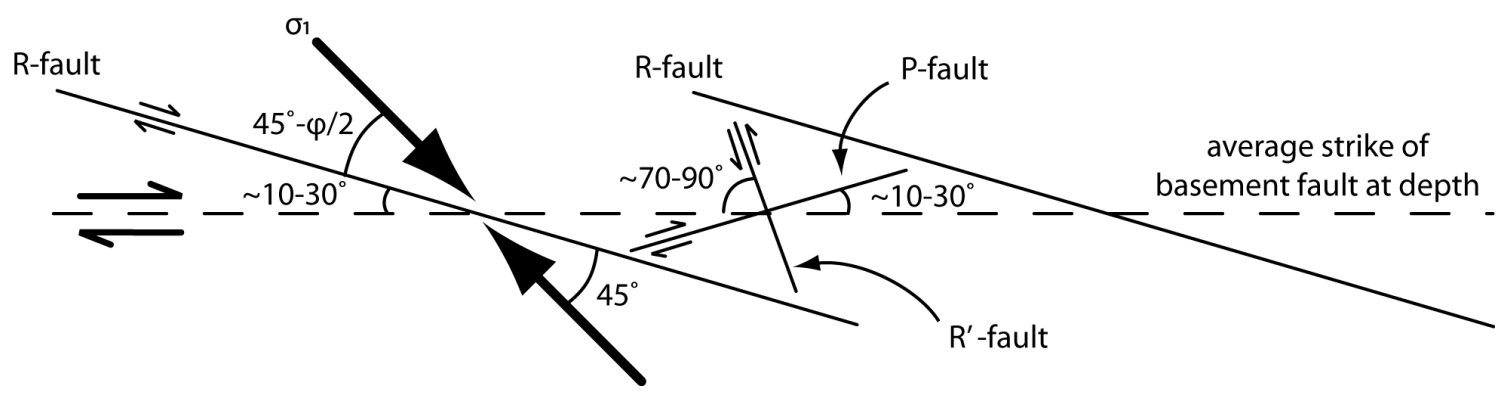

Figure 18 (Modified from Naylor et al., 1986). Different types of "secondary" strike-slip faults that may form in the overburden above a single basement pure strike-slip fault. Riedel $(R)$ faults form in an en echelon array. R-faults and conjugate Riedel ( $R$ ') faults form at equal acute angles on opposite sides of the direction of maximum compressive stress $(\sigma 1)$ as governed by friction and Coulomb fault mechanics. The R'-faults have an antithetic sense of slip with respect to the main fault. P-faults, which slip in a synthetic sense with respect to the basement fault, form in areas of overlap between two adjacent en echelon R-faults, and strike in the opposite direction than the R-faults do with respect to the strike of the basement fault.

a) Releasing Bend

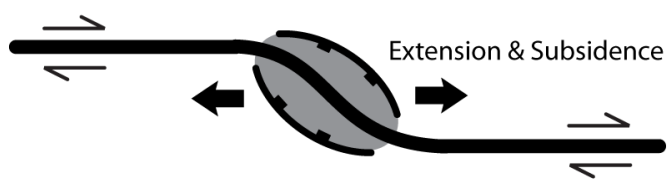

c) Restraining Bend

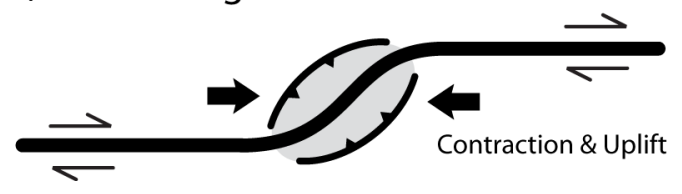

b) Releasing Stepover

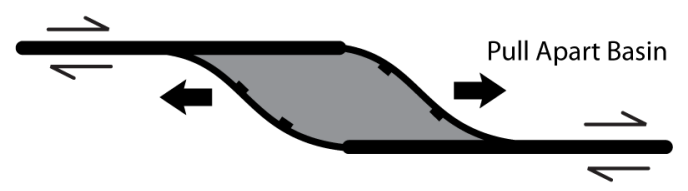

d) Restraining Stepover

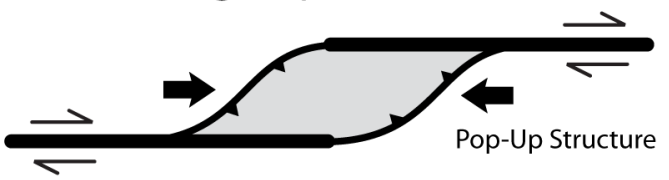

Figure 19 (From McClay \& Bonora, 2001). Map views of strike-slip fault restraining and releasing bends and stepovers, and the associated deformation. For a dextral fault, a bend to the right $(A)$ results in a localised area of extension and subsidence bounded by normal faults, while a bend to the left $(B)$ results in a localised area of contraction and uplift bounded by reverse faults. The opposite applies to a sinistral fault. For a dextral fault, a stepover to the right (C) results in the formation of pull apart basin bounded by normal faults, while a stepover to the left (D) results in the formation of a pop-up structure bounded reverse faults. Again, the opposite applies to a sinistral fault. 
Mechanisms that may produce restraining bends include progressive linkage of adjacent $e n$ echelon R-faults within a young evolving fault zone (e.g. Cowgill, 2004; Gamond, 1987), formation of lenticular sidewall ripout structures at scales ranging from outcrop to regional (Swanson, 1989), and the interaction of propagating strike-slip faults with pre-existing crustal structures such as ancient rift basins (Mann, 2007).

Cowgill (2004) and Gamond (1987) inferred that the origin of local restraining bends at outcrop to regional scales may be a natural consequence of progressive evolution of a strike-slip fault zone. Initially, a diffuse set of en echelon R-faults form above the strike-slip fault at depth, which eventually link up across contractional bulges via bridging P-faults, in an evolutionary sequence that has been observed and well documented in experimental analogue models (Hempton \& Neher, 1986; Tchalenko \& Ambraseys, 1970), and in surface ruptures of natural strike-slip faults deforming Quaternary sediments (Tchalenko \& Ambraseys, 1970). In its final evolutionary stages, the fault zone may consist of a throughgoing anastomosing fault zone (Mann, 2007).

\subsection{New Fault Mapping of the Central Section of the Wairarapa Fault}

\subsubsection{Collection of new surface map and RTK GPS data along the Wairarapa Fault}

In this study, we re-mapped the Wairarapa Fault and its associated surface deformation features between Waiohine River and Featherston (Figure 20, Plates 1-6). This mapping involved walking the fault out along its length, and interpretation of $\sim 1: 3,000$ scale colour vertical aerial photographs. We also examined and compiled the recent neotectonic to previous mapping by Rodgers and Little on the southern part of the fault between Featherston and Hinaburn ${ }^{1}$ (Figure 20, Plates 7-12). In addition, a Trimble R8 GNSS RTK GPS (Appendices A1 \& A2) was used to collect over 33,000 topographic data points $( \pm 1$ $\mathrm{cm}(2 \sigma)$ horizontal and $\pm 15 \mathrm{~cm}(2 \sigma)$ vertical precision) across two especially well defined pressure bulges located along the Wairarapa Fault just southwest of the Waiohine River (Plates $2 \& 3$ ). These data were krigged, gridded at a grid spacing of 1-4 $\mathrm{m}$ (4 $\mathrm{m}$ for larger pressure bulge and $1 \mathrm{~m}$ for smaller pressure bulge) and contoured using ArcMap, ArcGIS software to produce a microtopographic map or Digital elevation Model (DEM) for each of the pressure bulges $(1 \mathrm{~m}$ contours for larger pressure bulge and $0.4 \mathrm{~m}$ contours for smaller pressure bulge) For more detail see Appendix A5. Triangulated Irregular Network's

\footnotetext{
${ }^{1}$ Transcribed into ArcGIS database from unpublished map data of Rodgers \& Little. Maps including this data are attached as a series of 12 plates, and as ArcGIS files on CD, in the back pocket of this thesis.
} 
(TIN's) or 3D models were also created for each bulge (Appendix A6). From these DEM's and TIN's, precise estimates of the bulge shapes and volumes above a specified elevation could be determined.

\subsubsection{Segmented geometry of the Wairarapa Fault trace and its bulges}

The segmented geometry of the central part of the Wairarapa Fault trace is the focus of this study. We describe it below at three scales of observation, beginning with the smallest (Figure 20). The terms used to describe the fault at each scale are illustrated in Figure 21. Observed at scales smaller than $\sim 1: 250,000$, the central section of the Wairarapa Fault appears as a single continuous trace that gently bends from a strike of $042^{\circ}$ at its southern end, to $044^{\circ}$ in its central part, to $049^{\circ}$ at its northern end (Figure 20) (e.g. Grapes, 1999; 1991; Grapes \& Wellman, 1988). Along much of its length, the fault forms the boundary between the Mesozoic greywacke of the Rimutaka and Tararua Ranges, and the Holocene and latest Pliocene river gravels of the Wairarapa Valley (Grapes, 1991). An unusual feature of this fault is that its current scarp typically occurs at a distance of $\sim 100-400 \mathrm{~m}$ eastward from the topographically expressed range front, except for the southern section of the fault, where it locally coincides with the eastern edge of the ranges.

When observed at scales between $\sim 1: 250,000$ and $\sim 1: 50,000$, the central section of the Wairarapa Fault consists of five main segments, each up to $7 \mathrm{~km}$ long, that are arranged in a left-stepping en echelon pattern (e.g. Grapes, 1991), and that strike between $045^{\circ}$ and $055^{\circ}$ (referred to here as Type A fault segments) (Table 4, Figure 20). This strike is between $2^{\circ}$ and $11^{\circ}$ (average of $\sim 7^{\circ}$ ) clockwise of the longer-wavelength, average strike of the fault, mentioned above (Table 4, Figures 20 \& 21). At this scale the $\sim 2-7 \mathrm{~km}$ long segments are separated from one another across unfaulted stepover widths of $\sim 250-300 \mathrm{~m}$, and have distances of strike-parallel overlap between adjacent strands ranging between zero and $\sim 700 \mathrm{~m}$ (Table 4, Figures $20 \& 21$ ). The fault traces occur dominantly above the downthrown basement fault block (as defined by the average strike of the fault), whereas only a small proportion $(<20 \%)$ of their length occurs above the upthrown side of the fault. The sense of dip-slip displacement switches along strike where the fault segment crosses the basement fault (up-to-the-northwest above the downthrown fault block and up-to-the-southeast above the upthrown fault block). The areas of overlap between these Type A segments are filled by large contractional bulges (here called Type A bulges, described in section 3.7.1) of which five were mapped along this central Wairarapa Fault section. The fault is generally expressed by steep $\left(30^{\circ}-80^{\circ}\right)$ fresh-looking, linear scarps with an up-to-the-northwest sense of throw (Rodgers \& Little, 2006). The scarp height 


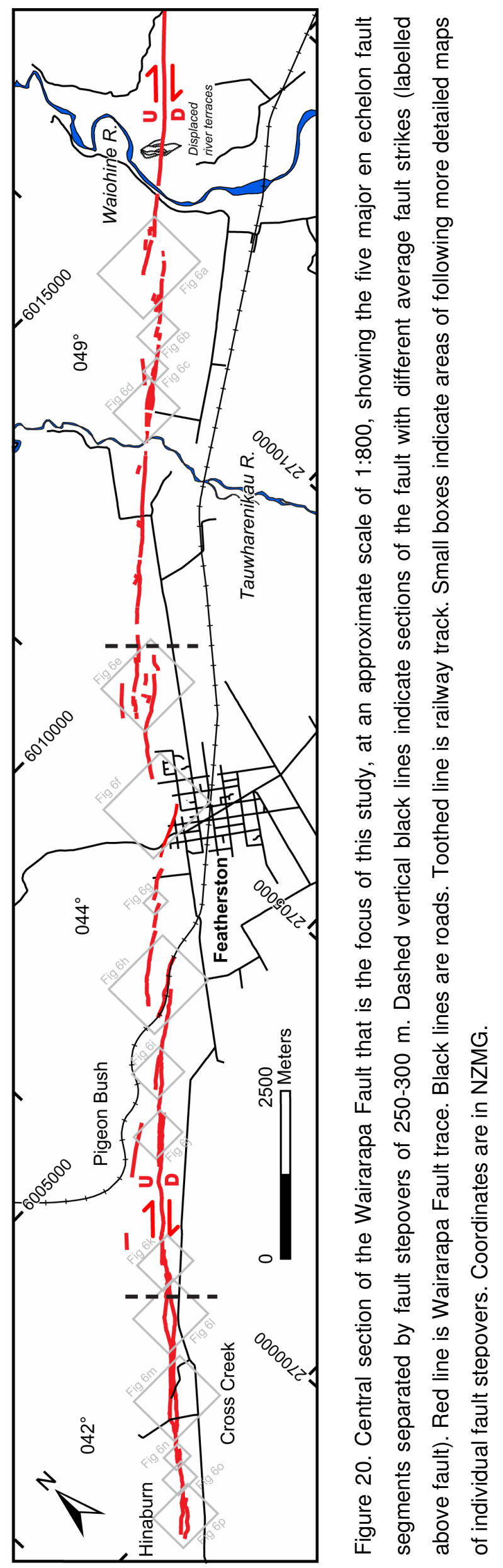




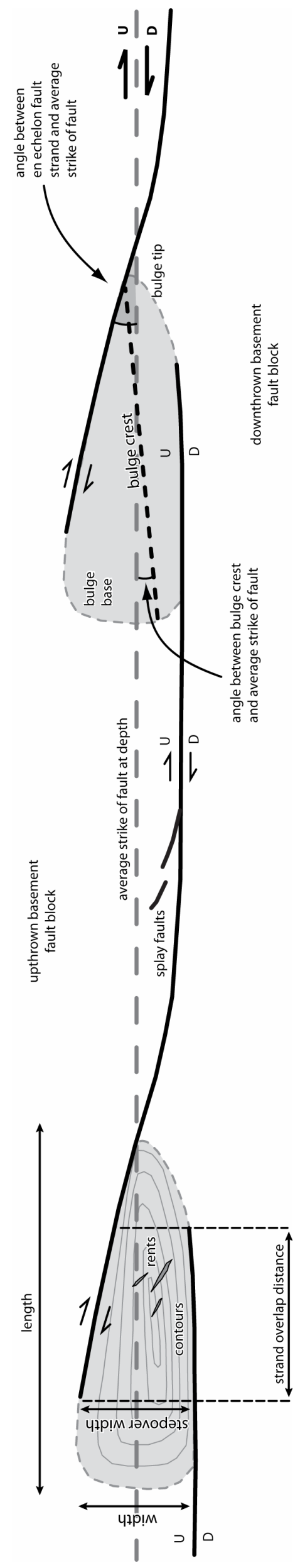

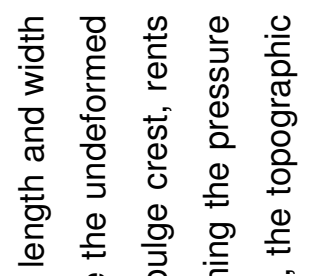

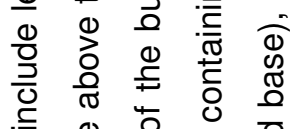

童

要

号

这

葱

苋 壳

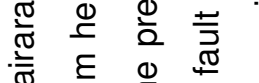

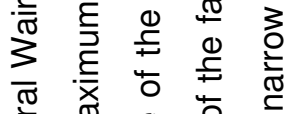

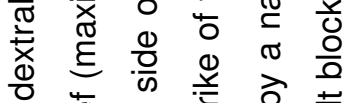

㐫

ธ

产

응

क ब

ब

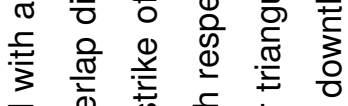

要

西

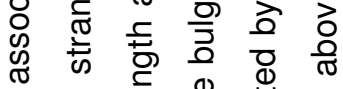

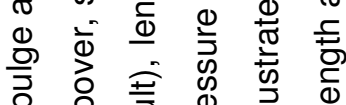

ठ

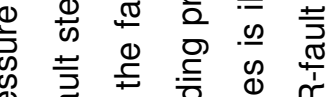

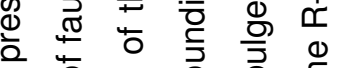

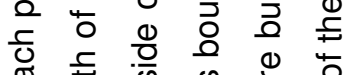

表 क क 至

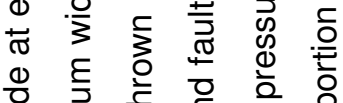

范

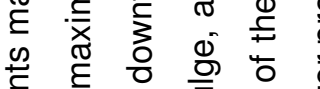

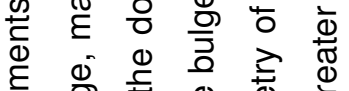

离

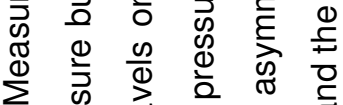

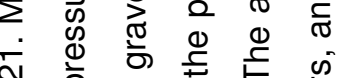

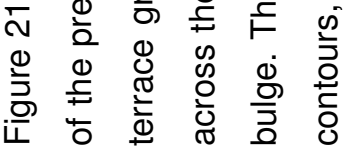




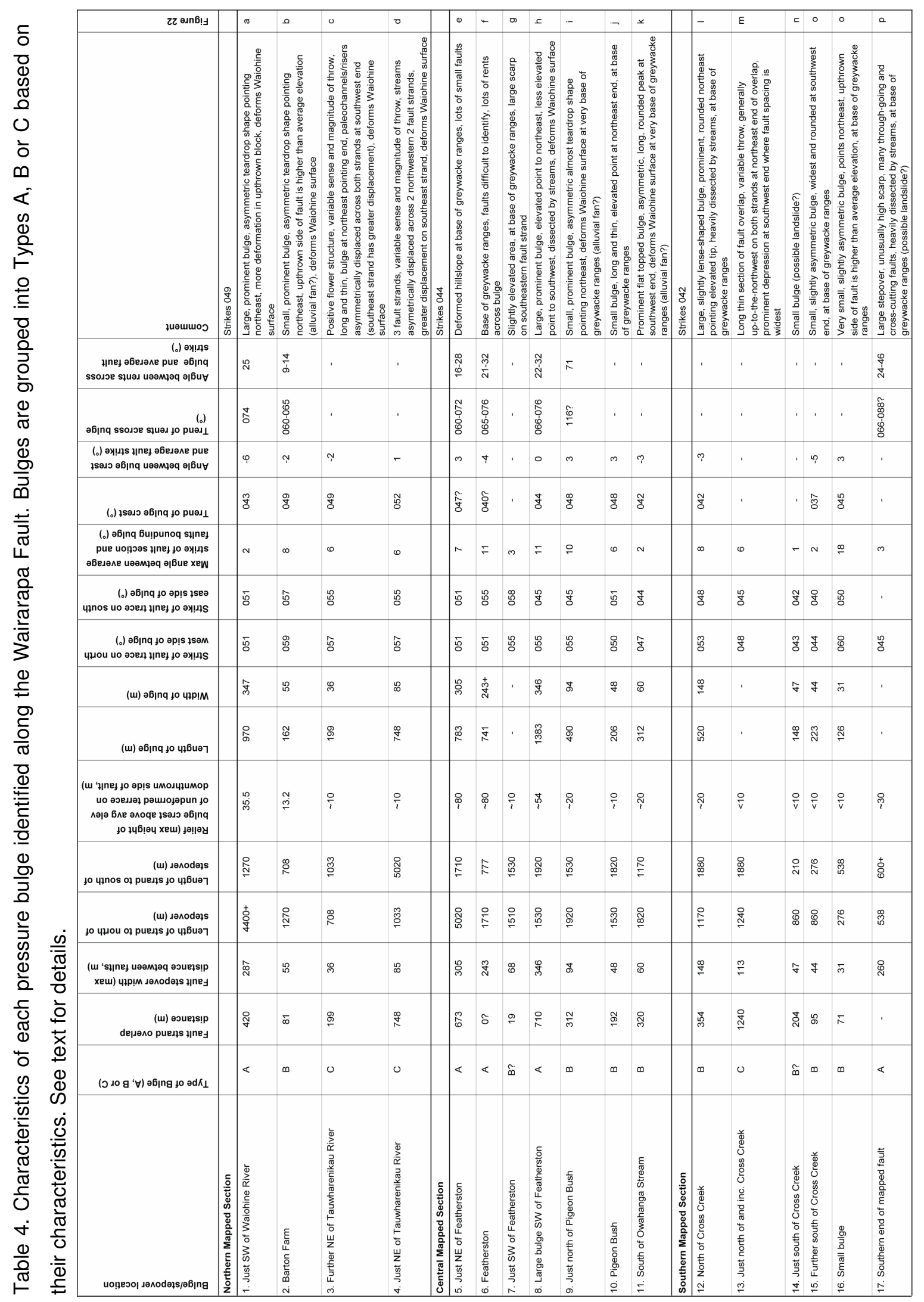


developed on the Waiohine surface is quite variable along the strike of a single fault segment, varying between $<10 \mathrm{~m}$ and $>80 \mathrm{~m}$. Most (but not all) of these variations appear to be related to position with respect to the contractional stepovers (e.g. Grapes, 1991).

At observation scales larger than $\sim 1: 50,000$, the central section of the fault includes $>20$ individual fault segments, ranging in length from $\sim 500 \mathrm{~m}$ to $>4 \mathrm{~km}$, that are arranged in a left-stepping en echelon pattern with respect to the longer Type A fault segments that contain them (Table 4, Figure 20, Plates 1-12). These faults are referred to here as Type B fault segments. They are similar in geometry to the Type A faults, but are distinctly smaller in size. These shorter Type B segments strike between $040^{\circ}$ and $060^{\circ}$, and are oriented between $2^{\circ}$ and $18^{\circ}$ (average of $\sim 6^{\circ}$ ) clockwise of the strike of the Type A fault segment that contains them (Table 4, Figure 21, Plates 1-12). At this most detailed scale, the Type B fault segments are separated across unfaulted stepover widths of $\sim 30-150 \mathrm{~m}$ (Table 4 , Figure 21, Plates 1-12). The overlap distances for these fault segments range from $\sim 20 \mathrm{~m}$ to $\sim 350 \mathrm{~m}$ (Table 4, Figure 21, Plates 1-12). The traces of these Type B fault segments predominantly occur on the downthrown basement fault block (as defined by the average strike of the fault), and have a sense of dip-slip displacement that switches along strike. The areas of overlap between these smaller Type B segments are also filled by contractional bulges that deform the Waiohine surface (here called Type B bulges, described in section 3.7.1) of which at least 9 were identified.

Three other bulges resolvable at a mapping scale of $>1: 50,000$ resembled positive flower structures (here called Type $C$ bulges, described in section 3.7.1). These bulges are bounded between Type B fault strands that are almost parallel to the average strike of the Type A fault segment that contains them, with a distance between adjacent fault strands of $\sim 40$ $110 \mathrm{~m}$, and a high fault overlap distance of $\sim 350-1200 \mathrm{~m}$ (Table 4, Plates 3 \& 11). Small splay faults were identified branching off the central part of Type B fault segments on the upthrown side of the fault. These splay faults are oriented $18^{\circ}-30^{\circ}$ clockwise to the average strike of the Type B fault segment they branch off, and are between $\sim 30 \mathrm{~m}$ and $\sim 200 \mathrm{~m}$ in length (Figure 21, Plates 2-4).

\subsubsection{Comparison of segmentation pattern with other strike-slip faults in New Zealand}

The Wairarapa Fault appears particularly strongly segmented relative to other major active strike-slip faults in New Zealand, such as the Wellington Fault, and faults of the 
Marlborough Fault System (MFS) at similar observation scales (although this comparison is limited to the extent of published maps and studies along these faults at equivalent scales). At small scales $(>250,000)$, the central Wairarapa Fault displays large stepovers $(>250 \mathrm{~m})$ on average every $\sim 5 \mathrm{~km}$ along strike, and at large scales $(>1: 50,000)$, displays small stepovers $(<150 \mathrm{~m})$ on average every $\sim 2 \mathrm{~km}$ along strike. By comparison, the Clarence Fault (MFS) at small scales $(>1: 140,000)$, displays just one stepover $(\sim 150 \mathrm{~m}$ wide $)$ in an along-strike distance of $\sim 30 \mathrm{~km}$ (Nicol \& Van Dissen, 2002), and at large scales $(\sim 1: 25,000)$, displays a continuous trace with no segmentation for $5 \mathrm{~km}$ along strike (Browne, 1992). Along the Awatere Fault (MFS) at small scales $(\sim 1: 250,000)$, one large $(\sim 200 \mathrm{~m})$ stepover is evident in an along-strike distance of $\sim 60 \mathrm{~km}$ (Little et al., 1998), and at a large scale $(\sim 1: 30,000)$ two small $(\sim 50 \mathrm{~m})$ stepovers are evident in $\sim 10 \mathrm{~km}$ along strike (Little et al., 1998; Mason et al., 2006). The Hope Fault (MFS) displays slightly more segmentation than the other faults of the MFS. At a small scale $(\sim 1: 300,000)$, six large (250-350 m) stepovers are observed in $\sim 50 \mathrm{~km}$ along strike (Langridge \& Berryman, 2005; Langridge et al., 2003), and at a larger scale ( 1:50,000) three small $(<150 \mathrm{~m})$ stepovers are observed in an along-strike distance of $\sim 10 \mathrm{~km}$ (Eusden et al., 2000). Hanmer Basin has formed in association with a large $(8-9 \mathrm{~km})$ stepover between two sections of the Hope Fault (Langridge \& Berryman, 2005). The Wellington Fault, to the west of the Wairarapa Fault in the NIDFB (Figure 16) is expressed as three long ( $>40 \mathrm{~km})$ sections separated by 2-3 km wide restraining bends or stepovers at a small scale $(\sim 1: 275,000)$ (Begg \& Johnston, 2000; Berryman, 1990; Langridge et al., 2005), and observed at a larger scale (1:50,000), these sections exhibit continuous traces with no stepovers between discontinuous or unlinked strands (Begg \& Mazengarb, 1996). One hypothesis might be that the Wairarapa Fault is incipient and has not developed through-going segments at the surface of the Waiohine gravels. The segmented nature of the Wairarapa Fault may be more clearly expressed than the above-mentioned strike-slip faults because the fault occurs well to the east of the range front and its scarp was largely buried by the Waiohine gravels after the LGM; rather than forming the boundary between a range front and a valley as is the case for the other faults.

\subsection{Analogue Models of Strike-Slip Deformation}

\subsubsection{Summary of four main categories of analogue models}

Surface deformation and faulting in strike-slip or transpressional environments has long been modelled using clay- and sand-box analogues (e.g. Cloos, 1928; Emmons, 1969; Riedel, 1929; Tchalenko 1968; Wilcox et al., 1973). Tchalenko (1970) describes the 
similarities between shear zones of different magnitudes and interprets these similarities to indicate that the deformation mechanisms or processes resulting in the observed surface deformation are comparable for analogue models and nature. Modelling of fault structures in analogue models requires the scaling rules to be satisfied (Hubbert 1937, 1951). In sand, faulting is well described by Coulomb-Mohr elastic-frictional plastic behaviour, in which the yield strength, $\tau_{\max }=c+\sigma_{\mathrm{n}} \tan \varphi$ (where $c$ is the cohesive strength, $\sigma_{\mathrm{n}}$ is the normal stress, and $\varphi$ is the internal angle of friction) (Naylor et al., 1986). Horsfield (1977) has shown that the use of dry sand, a typical frictional plastic material, allows proper downscaling of frictional strength of natural rocks, where stresses are scaled by the same ratio as lengths of the model to those in nature (Naylor et al., 1986). However, the effect of cohesive strength in nature is neglected by the use of dry sand with practically no cohesive strength in analogue models (Naylor et al., 1986). Clay models do not properly scale the yield strength of brittle rocks, as there is little or no pressure dependence on yield strength (Naylor et al., 1986). Clay models the behaviour of rocks with a high cohesive strength, and such rocks will show highly ductile behaviour before faulting (Naylor et al., 1986). Naylor et al., (1986) conclude that clay models may be more applicable for the ductile lower crust, and sand models are more appropriate to faulting in sedimentary rocks of the brittle upper crust.

Previously published analogue model experiments can be separated into four main categories. The most common is the case of deformation of a previously unfaulted sand overburden above a single strike-slip or oblique-slip basement fault (e.g. Naylor et al., 1986; Richard, 1991; Richard et al., 1995), by application of varying ratios of strike-slip to dip-slip and basement fault dips to the rigid base plates beneath the sand. These experiments are most applicable to studying the effects of strike-slip reactivation of a vertical basement fault on an initially unfaulted non-cohesive overburden (Schreurs, 2003). In these types of experiments the structures forming in the overburden are secondary and directly connected to the pre-existing basement fault, where the through-going anastomosing fault zone does not develop independently (Schreurs, 2003).

Naylor et al., (1986) summarise the fault evolution in the overburden above a strike-slip basement fault with increasing displacement in five stages (Naylor et al., 1986). In the first stage, en echelon R-faults form, overlapping slightly with each other. The basement displacement required to generate the first faults at the surface is a small fraction of the overburden thickness (Naylor et al., 1986). Each fault is described as a scissor fault, with a sense of vertical displacement that varies along strike as the fault crosses the concealed basement fault at depth. Increasing horizontal displacement causes oblique shortening of 
the cover and the formation of zones of positive vertical relief in the area of overlap between adjacent $\mathrm{R}$-faults, with the crests of these bulges oriented approximately parallel to the strike of the bounding R-faults (Schreurs, 2003; Schreurs \& Colletta, 1998). In the second stage, short-lived splay faults propagate away from the initial R-faults at or near their tips, striking at a greater angle to the basement fault than the R-faults (Naylor et al., 1986). In the third stage, new R-faults develop, striking at a lower angle to the basement fault than the initial R-faults, after the short-lived splay faults become inactive. These lower-angle R-faults propagate from the tips of the initial R-faults, or link between two preexisting R-faults. Antithetic R'-faults, are occasionally formed especially if there is substantial overlap between the adjacent R-faults, but the displacements on these R'-faults are generally small compared to those on the R-faults. The first P-faults form, and link adjacent R-faults (Naylor et al., 1986). In the fourth stage, more P-faults may form. The lower angle R-faults and P-faults connect the discontinuous R-faults, and the first shear lenses form. The fifth stage represents the final fault pattern, which is an anastomosing zone of faults defining shear lenses, with displacements being concentrated on the central through-going faults (Naylor et al., 1986).

The second type of analogue experiment is the case of distributed deformation of a brittle upper layer overlying a viscous lower layer (e.g. Casas et al., 2001; Schreurs, 2003; Schreurs \& Colletta, 1998). In these experiments, the applied displacement has been varied between strike-slip simple shear to oblique transpression at different relative convergence angles. The basal viscous layer in these experiments distributes shear (or slightly transpressive) deformation homogeneously over the entire width of the model. For this reason, these models are more applicable to studying the fault evolution across broad shear zones (several hundred kilometres wide), where deformation is driven by distributed flow at depth (Schreurs, 2003; Schreurs \& Colletta, 1998). In the early stages of fault evolution, the surface pattern of faults in the brittle layer (e.g. sand) can be quite similar to that observed in models of deformation of the overburden above a single basement strike-slip fault (case above), in that en echelon $\mathrm{R}$-faults dominate initial shear deformation and are subsequently linked by secondary structures in the overlap areas (Casas et al., 2001; Schreurs, 2003; Schreurs \& Colletta, 1998). With increasing shear displacement however, significant differences in fault evolution in the upper brittle layer may develop between the two types of models (Schreurs, 2003). In distributed deformation experiments, the final anastomosing fault zone strikes at an angle of $\sim 15^{\circ}$ to the shear direction and increases in width with increasing shear, whereas in basement-induced strike-slip experiments, the fault zone is 
parallel to the basement fault and increasingly narrows with displacement on the basement fault (Schreurs, 2003).

The third type of analogue experiments are those modelling the deformation of a previously unfaulted overburden above a rigid restraining bend in the basement fault (basal plate of model) (e.g. McClay \& Bonora, 2001; Richard et al., 1995). In these experiments, the bend angles (underlapping or overlapping faults) and spacing between adjacent faults were varied. The modelled deformation above a $30^{\circ}$ restraining bend exhibits a welldefined rhomboidal bulge directly above the fault bend, bounded by reverse-oblique strikeslip faults that form above (or slightly outside of) the concealed offset basement faults. Two pairs of only slightly curved reverse faults form at an orientation parallel to the bend in the basement fault (McClay \& Bonora, 2001). The outer pair of reverse faults bound the zone of uplift (bulge), whereas the inner pair of reverse faults bound a small zone of locally greater relief super-imposed on the main bulge (McClay \& Bonora, 2001). Reverse-oblique strike-slip faults may form across the central uplifted region of the bulge in the later stages of its evolution to link the straight strike-slip faults at either end of the fault bend (Figure 4 of McClay \& Bonora, 2001). The modelled deformation above a $90^{\circ}$ restraining bend is similar to that described above for a $30^{\circ}$ bend, however in the $90^{\circ}$ case, the bulge is more sigmoidal in shape, and is bounded by more distinctly curved reverse-oblique strike-slip faults than in the case for a $30^{\circ}$ bend (McClay \& Bonora, 2001). Antithetic R-faults with small displacements may develop in the central part of the bulge (Figure 6 of McClay \& Bonora, 2001).

The fourth type of analogue model experiments focus on the development of wrench folds in the overburden above a strike-slip basement fault (e.g. Odonne \& Vialon, 1983; Wilcox et al., 1973). Discrete kinematic models relating fold shortening, and axial rotation and extension are also common in the literature (e.g. Jamison, 1991). In most models, the folds in the deforming clay or wax cover form symmetrically above a pure strike-slip fault at an initial axial orientation of $45^{\circ}$ to the fault (Jamison 1991; Odonne \& Vialon, 1983; Wilcox et al., 1973), where right-stepping folds form in dextral slip regimes (Sylvester, 1988). As the displacement on the fault increases, the fold axes rotate towards the fault and the axial extension of these folds increases (e.g. Odonne \& Vialon, 1983; Sylvester, 1988). With increased displacement the initial folds are broken first by extension fractures and then by faults (Wilcox et al., 1973). Folds forming in a convergent strike-slip setting initiate with axes oriented at $<45^{\circ}$ to the master fault trend (Sanderson \& Marchini, 1984). As in the case of pure strike-slip, progressive fold development is accompanied by rotation of the 
fold axes. The relative amount of rotation and axial extension both decrease as the amount of convergence increases, and for a purely convergent system, there is no fold axis rotation, and no axial extension (Jamison, 1991).

\subsubsection{Effects of boundary conditions on analogue models of strike-slip fault zones}

In this section we describe the effects of various boundary conditions on the surface deformation and fault geometry observed in analogue models of strike-slip deformation. The boundary conditions varied in different published modelling studies include the obliquity of convergence, the overburden thickness, the amount of displacement or shearing, and the rheology and homogeneity of the overburden material.

The effect of the local convergence angle on the segmented pattern of surface faults has been determined from analogue experiments modelling deformation of a sedimentary overburden above a single reverse oblique-slip basement fault (e.g. Richard, 1991; Richard et al., 1995), and transpressive distributed deformation (e.g. Casas et al., 2001; Schreurs \& Colletta, 1998), with different angles of convergence. In pure strike-slip experiments with a vertical basement fault, en echelon $\mathrm{R}$-faults typically form at $\sim 10^{\circ}-30^{\circ}$ to the strike of the basement fault $\left(17^{\circ}-20^{\circ}\right.$ in densely packed sand according to ideal Coulomb-Mohr behaviour). The fault distribution in the overburden is symmetrical about the main fault in basement, and centred above it, where that fault is vertical (Richard et al., 1995).

For the slightly transpressive case of a convergence angle of $\sim 7^{\circ}$ with respect to the strike of the basement fault, on basement faults that are non-vertical (e.g. dip $45^{\circ}$ ), the pattern and strike of surface faults remains closely similar to the case of a pure strike-slip fault, but the surface deformational structures exhibit a slight asymmetry with respect to the strike of the basement fault (see below, Richard et al., 1995). If the angle of convergence is increased to $\sim 20^{\circ}$ to the strike of the basement fault, the modelled secondary faults strike at angles of $>30^{\circ}$ to basement fault strike (Richard et al., 1995). In this case, the fault pattern developed in the previously unfaulted overburden is strongly asymmetrical. The faults are curved in plan view, and chiefly populate the downthrown fault block (Richard et al., 1995). Each fault accommodates a reverse-oblique component of motion, but displacement is commonly partitioned between strike-slip dominant faults that occur close to the trace of the main basement fault, and dip-slip dominant fault that occur farther away from the basement structure (Richard et al., 1995). If the convergence angle is increased to $\sim 50^{\circ}$, the faults that form are dominantly thrust faults, arranged en echelon to the strike of the basement fault, but at a low angle of $\sim 10^{\circ}$. For even greater convergence angles, a single 
thrust fault forms parallel to the basement fault above the downthrown side of the basement fault block. For a given convergence angle, a change in basement fault dip from $45^{\circ}$ to $54^{\circ}$ does not markedly change the geometry of surface faulting (Richard, 1991; Richard et al., 1995). In experiments that model surface deformation above a zone of distributed transpressive deformation, rather than above a single discrete basement fault, a convergence angle of $0^{\circ}-15^{\circ}$ results in localised deformation and structures that are typical of a strike-slip regime (Casas et al., 2001). A marked change from strike-slip-dominated transpressional structures to thrust-dominated transpressional structures occurs at convergence angles of $\sim 20^{\circ}$ (e.g. Casas et al., 2001; Schreurs \& Colletta, 1998).

The effect of overburden thickness on the surface fault geometry has been described for analogue models of a sedimentary overburden above a single basement strike-slip fault (e.g. Naylor et al., 1986; Ueta et al., 2000). In these models, the R-faults forming in the overburden always converge into that basement fault. By experimenting with different sand-pack thicknesses, Naylor et al., (1986) show that the length of the first R-faults to develop, and the overall width of the fault zone at the surface, both scale with the thickness of the overburden and can be used to determine the approximate depth of sediment overlying the basement fault. The width of the fault zone is approximately equal to the overburden thickness, and the R-fault length is $\sim 1-2$ times the overburden thickness (Naylor et al., 1986). Ueta et al., (2000) find that for a thinner overburden thickness, the strike of R-faults with respect to that of the basement fault, the dip of R-faults, and the surface width of the fault zone all decrease. Faults form at a lower angle to the basement fault when the overburden is thin and at a higher angle $\left(>15^{\circ}\right)$ when the overburden is thick (Sylvester, 1988). It is difficult to determine from the analogue models what the effect of overburden thickness is on the rate of fault evolution (e.g. Naylor et al., 1986; Schreurs, 2003; Ueta et al., 2000), however one speculates that the required displacement on the basement fault to reach a particular stage of fault evolution or maturity should increase with the thickness of the overburden.

The surface geometry of faults forming in a strike-slip setting is strongly influenced by the amount of displacement on the basement fault beneath the overburden (Naylor et al., 1986), or the amount of shearing in models of distributed deformation (Schreurs, 2003). The evolution of a fault zone above a single basement strike-slip fault was first described from scaled sandbox experiments by Cloos (1928) and Riedel (1929). The progressive evolution of a strike-slip fault zone according to Naylor et al., (1986) was summarised in section 3.6.1 for basement strike-slip fault models, and is similar to the fault zone evolution 
in distributed deformation experiments (Schreurs, 2003).

The effects of overburden material and its homogeneity (including the case of synsedimentation) on the surface fault geometry have been investigated using analogue models of deformation above a single basement strike-slip fault (e.g. Richard et al., 1995; Ueta et al., 2000). R-faults forming in densely packed sand strike $34^{\circ}-43^{\circ}$ to the basement fault, rather than $17^{\circ}-20^{\circ}$ (in densely packed sand according to ideal Coulomb-Mohr behaviour) and have a more pronounced helicoidal aspect with fault dips of $\sim 40^{\circ}$. R-faults forming in loose sand strike $14^{\circ}-23^{\circ}$ to the basement fault, and have a less pronounced helicoidal shape and steeper fault dips $>75^{\circ}$ (Richard et al., 1995; Ueta et al., 2000). In pre-existing inhomogeneous sedimentary sequences (layers with different cohesive strength and angles of internal friction) and sequences deposited during faulting, R-faults are deflected away from the basement fault when propagating up into a coarser sand layer from a finer sand layer (Richard et al., 1995). Upward branching of R-faults occurs at layer interfaces, resulting in a faulted zone that is wider in map view than expected for a pure strike-slip fault, with R-faults that develop at up to $30^{\circ}$ to the basement fault (Richard et al., 1995; Tchalenko, 1970).

\subsection{Deformational Bulges along the Wairarapa Fault}

\subsubsection{Classification of bulge types and their characteristics}

We identified a total of 17 deformational pressure bulges along the central Wairarapa Fault (Figures 22a-p). These bulges occurred in relation to restraining stepovers in the fault trace that can be defined at two different observation scales (as described in section 3.5.2). We characterise these bulges into three main types (A, B or C) according to their size, shape, volume, surface fault geometry and distribution along the fault. The bulge characteristics that we describe are illustrated in Figure 21. In this section, we summarise the characteristics of each bulge type (Table 4 and Figures 22a-p), and describe the general relationships in bulge characteristics (Figure 23a-d).

Type A and B bulges have very similar characteristics, and are distinguished from one another chiefly on the basis of their size. Five Type A bulges were identified along the Wairarapa Fault (Figures 22a, e, f, h \& p, Table 4). These bulges coincide with left stepovers between adjacent Type A fault segments, that are $\sim 250-350 \mathrm{~m}$ wide. The folds have maximum crested relief of $\sim 30-80 \mathrm{~m}$ above their undeformed flanks and lengths of 700-1400 $\mathrm{m}$ (Figure 21, Table 4). The faults bounding these bulges strike an average of 
$\sim 6^{\circ}$ clockwise to the average strike of the dextral-slip Wairarapa Fault, however, at a few bulges the faults curve near the bulge tip to become more oblique to the average strike of the fault (up to $22^{\circ}$ clockwise to the average strike of the fault). The bulge crests trend between $\sim 6^{\circ}$ anticlockwise to $\sim 3^{\circ}$ clockwise to the average strike of the fault. Rents across these larger bulges are common; typically these strike $\sim 20^{\circ}-30^{\circ}$ clockwise to the average strike of the fault (Table 4).

Type B bulges are the most common along the Wairarapa Fault, with at least nine recognised (Figures 22b, g, i-1, n \& o). They occur in the small left stepover area between adjacent Type B fault segments, across stepover widths of $\sim 30-150 \mathrm{~m}$. They have maximum crestal relief of $<20 \mathrm{~m}$, and often $<10 \mathrm{~m}$, and lengths of $\sim 120-500 \mathrm{~m}$ (Table 4). The faults bounding these bulges strike an average of $\sim 6^{\circ}$ clockwise to the average strike of the Type A fault segment that contains them (see description in section 3.5.2). The bulge crests trend between $\sim 5^{\circ}$ anticlockwise and $\sim 3^{\circ}$ clockwise to the average strike of the fault. Rents across these smaller bulges are generally not observed.

Type A and B bulges typically have an asymmetric, triangular shape in plan-view (e.g. Figures 22a-b, e-i \& o-p) with a sharp northeast-plunging tip (Figure 21) that terminates against the northern bounding fault, and a rounded base that spreads out between the two bounding faults at their southwest end, resembling large mole tracks. The two clearest examples of Type A bulges with this shape (Figures 22a $\&$ h) deform the Waiohine surface well away from the Rimutaka Ranges, while the other three Type A examples (Figures 22e, f \& p) are somewhat complicated by their proximity to the topography of the Rimutaka and Tararua Ranges. Four examples of Type B bulges clearly show this shape (Figures 22b, g, i \& o). Two type B bulges (Figure $22 \mathrm{j} \& \mathrm{l}$ ) have rounded, gradually sloping northwest bases, and pointy tips that plunge southwest. Another Type B bulge (Figure 22k) appears as more of a horst-type block upthrown between its two bounding en echelon faults, with a relatively flat top surface. This bulge also has a rounded base to the southwest. Its northeast pointing tip is not well defined, as the two faults that bound the bulge exhibit an up-to-the-northwest sense of slip on both strands to the north of the bulge. Type B bulges are mostly identified where the Wairarapa Fault trace is $>100 \mathrm{~m}$ east of the range front.

Type A and B bulges are asymmetrical in cross section. They display a high, steep scarp on their southeastern limb or flank, and a broader, more gradual slope on their northwestern limb. The sense of dip-slip on the fault strand bounding the northwest bulge flank is up-tothe-southeast, whereas the sense of dip-slip on the southeast strand is up-to-the-northwest. 

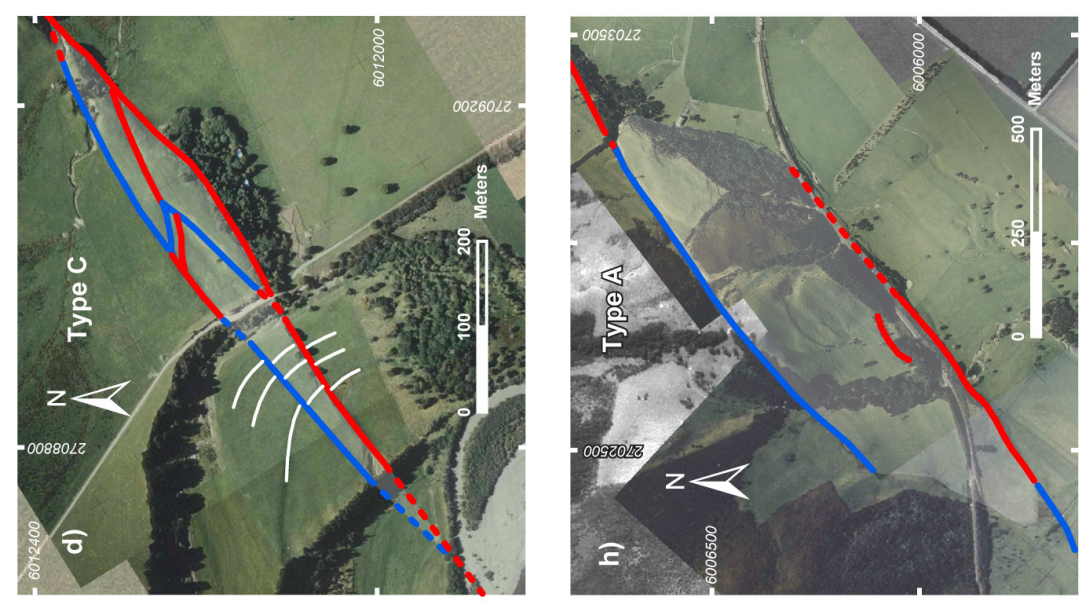

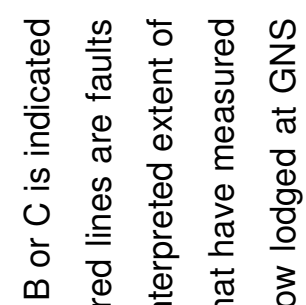
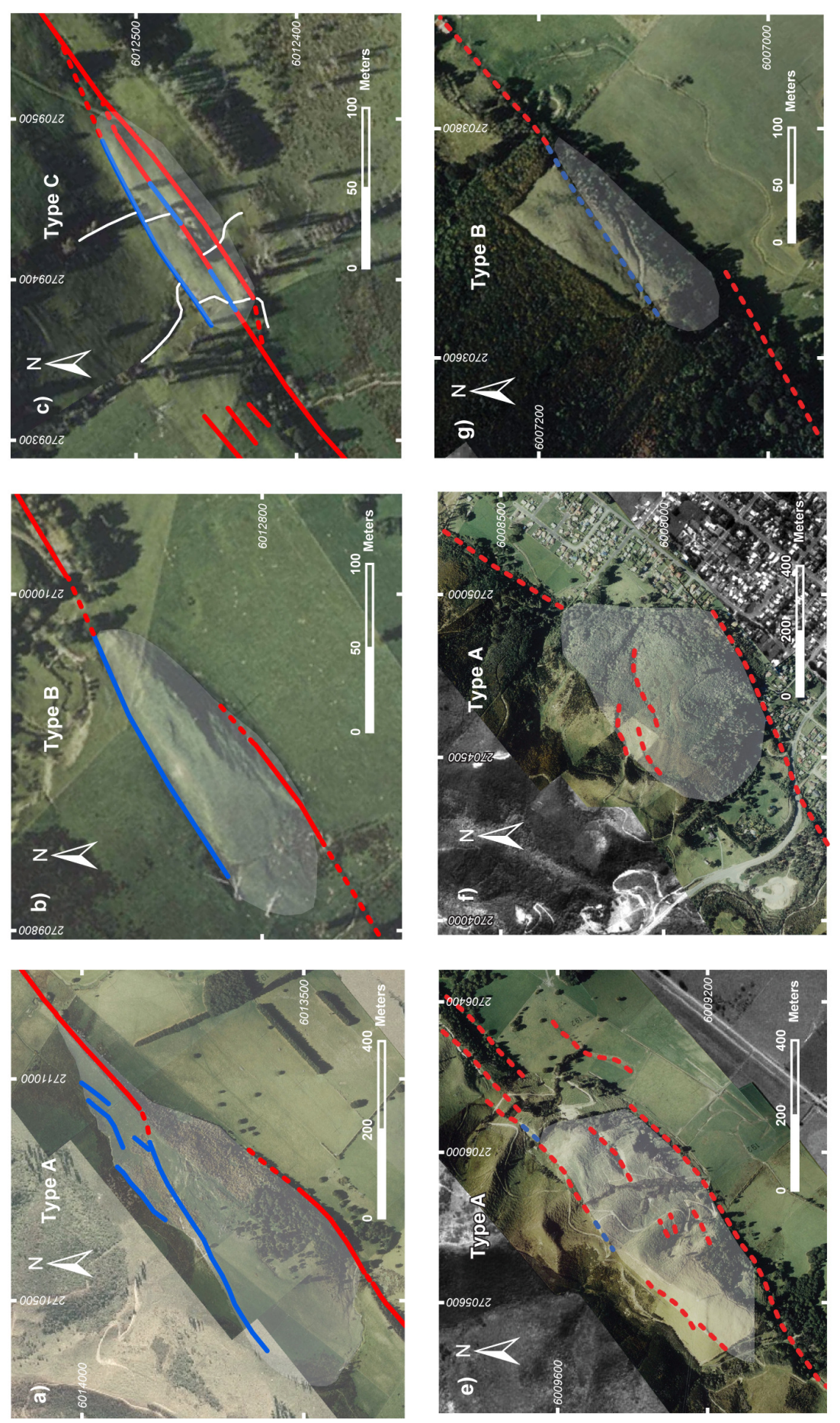

ष্ড

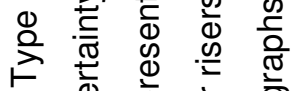

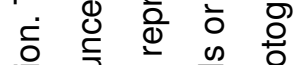

竞

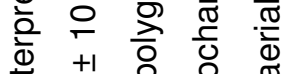

$\stackrel{ \pm}{\Xi} \stackrel{0}{\square}$

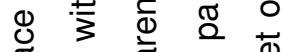

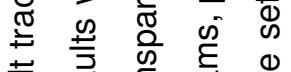

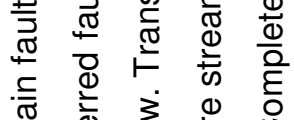

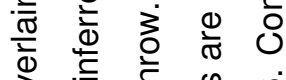

ठ

站

प)

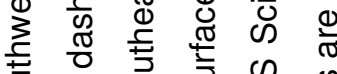

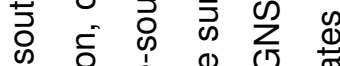

๑ 응 仓

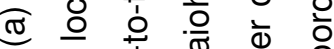

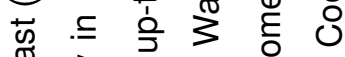

站

产

은 至

志 $匚$ ह

난

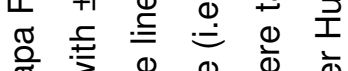

휸

京 売

๑ ర

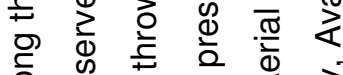

은

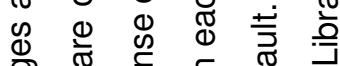

을 ๗

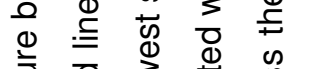

站

口 $ᄃ$ व

交

ิㅡㄴ 이 을

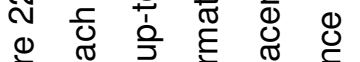

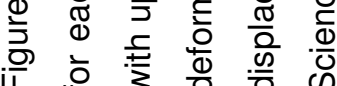



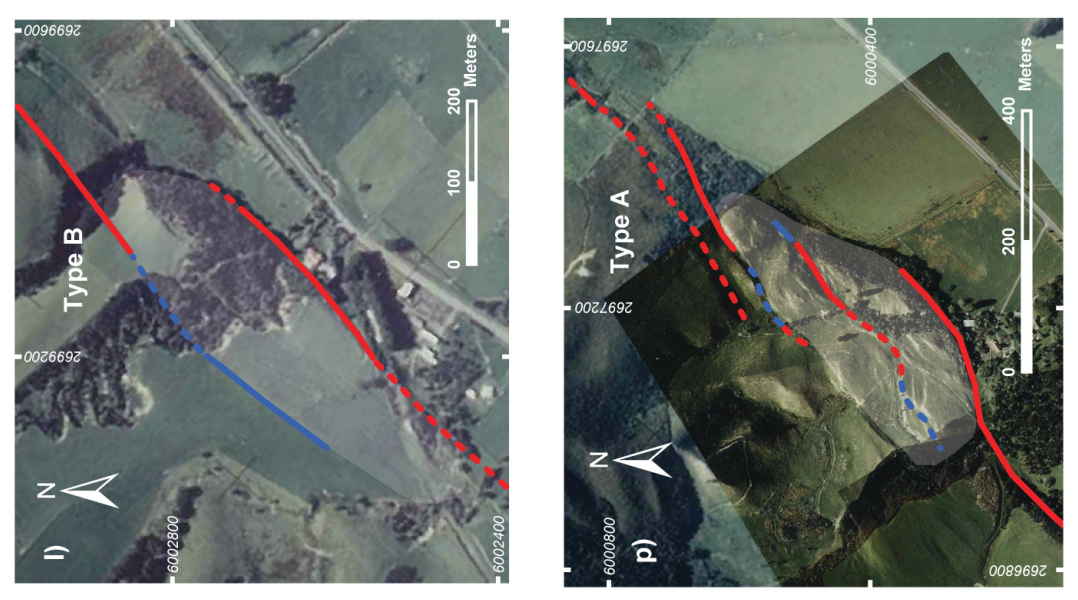

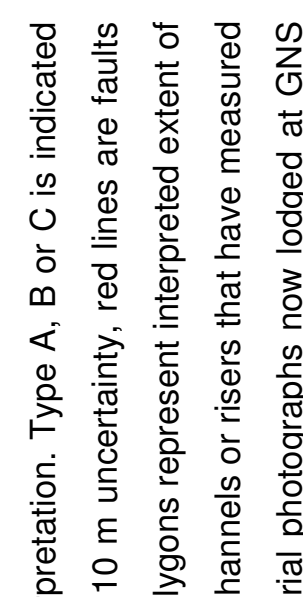
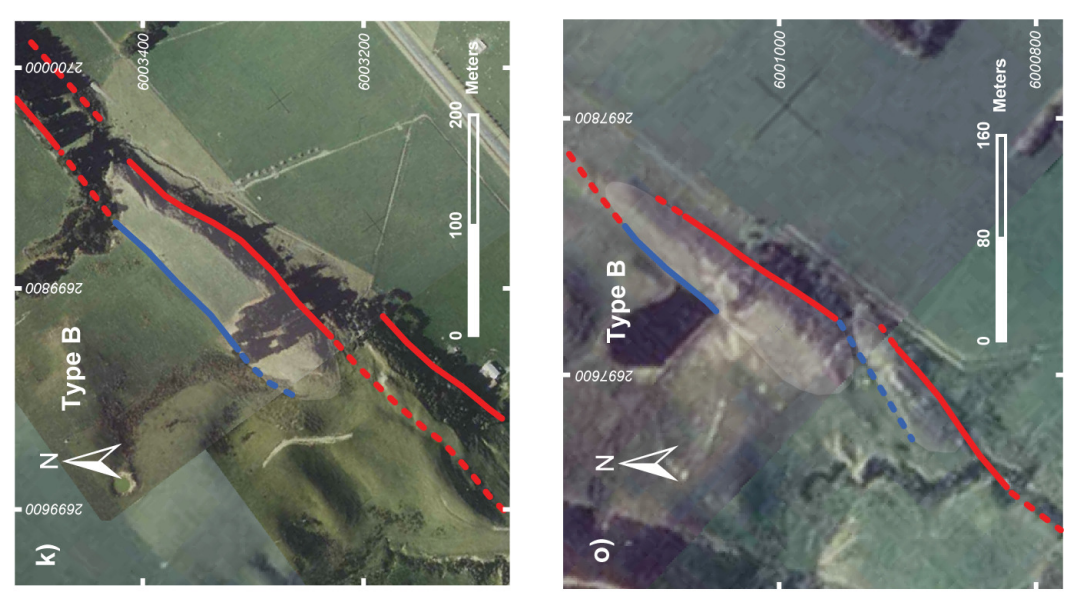

인 +1

.

苂

志

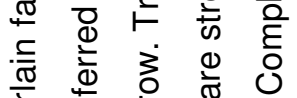

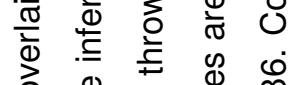

ठ ญ

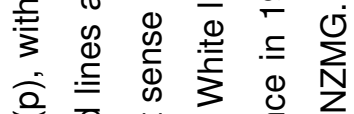

荞

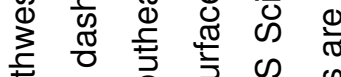
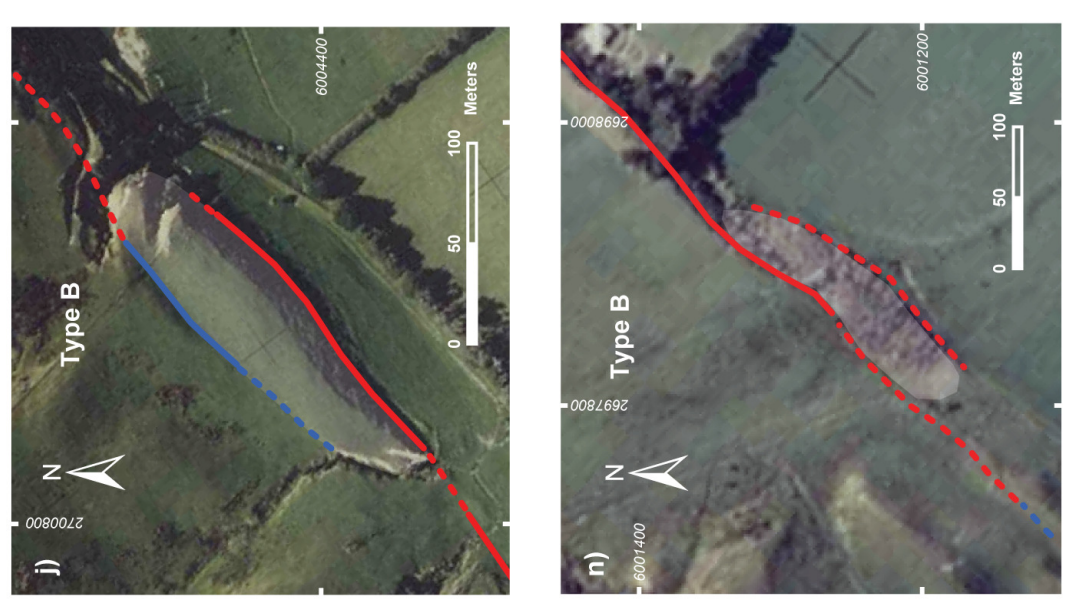

声

要

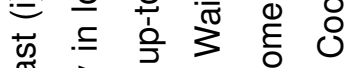

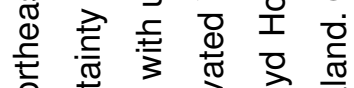

인

$\varepsilon$ 䆑

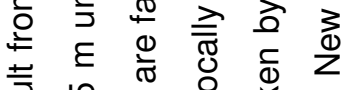

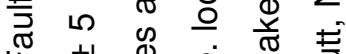

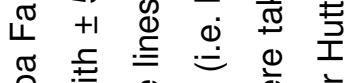

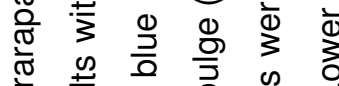

市
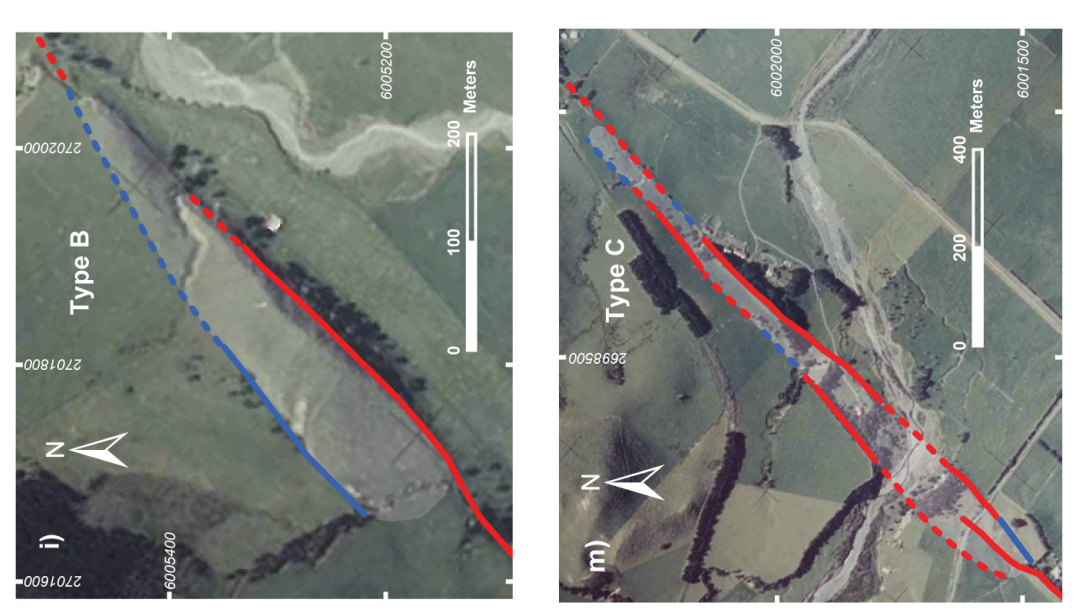

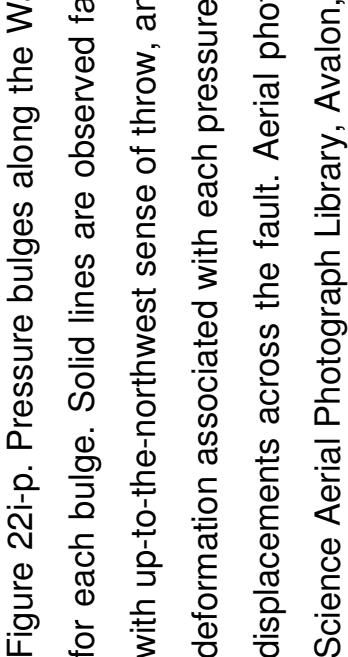


Displaced streams at the southwest ends of at least two Type A bulges (Figures 22a \& h) and four Type B bulges (Figures 22b, j, k \& o), clearly exhibit a larger component of strikeslip displacement on the northwest fault bounding the bulge, and little, or no strike-slip displacement on the southeast bounding fault (see discussion in section 3.8.5).

Type C bulges and/or depressions are the least common along the Wairarapa Fault, with only three examples defined here (Figures 22c, d \& m, Table 4). These long (200-750 m), high aspect ratio bulges have formed between two closely spaced (30-120 m) and parallel (but not necessarily en echelon) fault strands. The sense and magnitude of vertical slip is quite variable across these bulges, and they probably resemble positive flower structures in cross section. The maximum relief of the up-bulged parts of these structures is $<10 \mathrm{~m}$. The Type $\mathrm{B}$ faults bounding these bulges are curved, but are generally oriented almost parallel to the average strike of the fault, and converge at either end of the bulge. The bulge crests trend approximately parallel $\left(\sim 0-3^{\circ}\right.$ clockwise) to the average strike of the fault. Faults cross-cut the bulge structures, oriented $5^{\circ}$ anticlockwise to $36^{\circ}$ clockwise to the average strike of the fault, and these faults have a variable sense of vertical slip. Rents across these bulges are generally not observed.

These Type C bulges appear more symmetrical in cross section than Types A and B, however, their low crestal relief makes their sense of symmetry difficult to determine. In general, the sense of dip-slip on the fault strand bounding the northwest bulge flank is upto-the-southeast, whereas the sense of dip-slip on the southeast strand is up-to-thenorthwest, however, the sense of slip on both of these strands varies along strike, and is complicated by the variable throw between the two strands. Strike-slip and dip-slip displacements may be asymmetrically distributed across the two (or more) fault strands bounding the bulge flanks, with greater components of both strike-slip and dip-slip accommodated on one of the more southeastern faults than the northwestern fault strand (e.g. Figures 22c \& d).

Strike- and dip-slip displacements across the bounding strands at two Type C bulges along the Wairarapa Fault have been quantified. Displacements were reported by Rodgers and Little (2006) for the two main bounding faults at the Tauwharenikau River Type C bulge (Figure 22d). There, two paleochannels and an abandoned terrace riser displayed an average of $8.4 \pm 1.0 \mathrm{~m}$ dextral displacement for the fault bounding the northwest side of the bulge, and $16.0 \pm 1.5 \mathrm{~m}$ dextral displacement for the fault bounding the southeast side of the bulge (Rodgers and Little, 2006). The vertical displacements are $0.4 \pm 0.2 \mathrm{~m}$ (up-to-the- 
southeast) and $3.8 \pm 1.0 \mathrm{~m}$ (up-to-the-northwest), for the northwest and southeast bounding faults respectively (Rodgers and Little, 2006). At another Type C bulge just northeast of the Tauwharenikau River bulge, three fault strands are mapped (Figure 22c). Two streams crossing the bulge are dextrally displaced across the northwestern strand by $\sim 10 \mathrm{~m}$, while showing $\sim 14$ and $\sim 33 \mathrm{~m}$ dextral displacement across the central fault strand. The channels do not show any clear dextral displacement across the southeastern strand however, this strand displays the largest (unmeasured) vertical displacement (up-to-thenorthwest). The sense of throw on the central fault strand is variable, and on the northwest strand is up-to-the-southeast.

General relationships in the bulge characteristics are illustrated by the graphs in Figure 23ad. The types of bulges are differentiated most obviously according to fault stepover width and bulge crestal relief. As can be seen in Figure 23a, the crestal relief of a bulge increases approximately linearly with fault stepover width, with the stepover width averaging $\sim 5$ times the bulge relief. The length of a bulge also increases approximately linearly (factor of $3-4)$ with bulge width (Figure 23b). Length to width ratios ( 2-3) for large bulges along the Central Kunlun Fault zone in Tibet are also plotted for comparison (Lin et al., 2004). Interestingly, there is not a clear relationship between bulge relief and the strike of the en echelon segments with respect to the average strike of the fault (Figure 23c); however, Type A bulges appear to have greater relief where the Type A faults bounding them strike at a greater angle with respect to the average strike of the basement fault. The ratio of strand overlap distance to fault stepover width displays a general increasing trend for Type A and $B$ bulges (Figure 23d). Type C bulges typically exhibit a higher strand overlap distance for their relatively narrow stepover widths (Figure 23d).

\subsubsection{Volume calculations and fault convergence depths for two bulges along the Wairarapa Fault}

The topography of two particularly well expressed and accessible pressure bulges that deform the Waiohine surface (Type A and B; Figures 22a \& b) were mapped in detail using a Real-Time Kinematic (RTK) Global Positioning System (GPS) (see also Appendices A1 \& A2) in order to quantify aspects of their shape, volume and surface features (e.g. faults and rents). Our aim was to provide data from which volume calculations similar to those described by Groshong (1994) could be made, and to make inferences about the fault geometry at depth. 

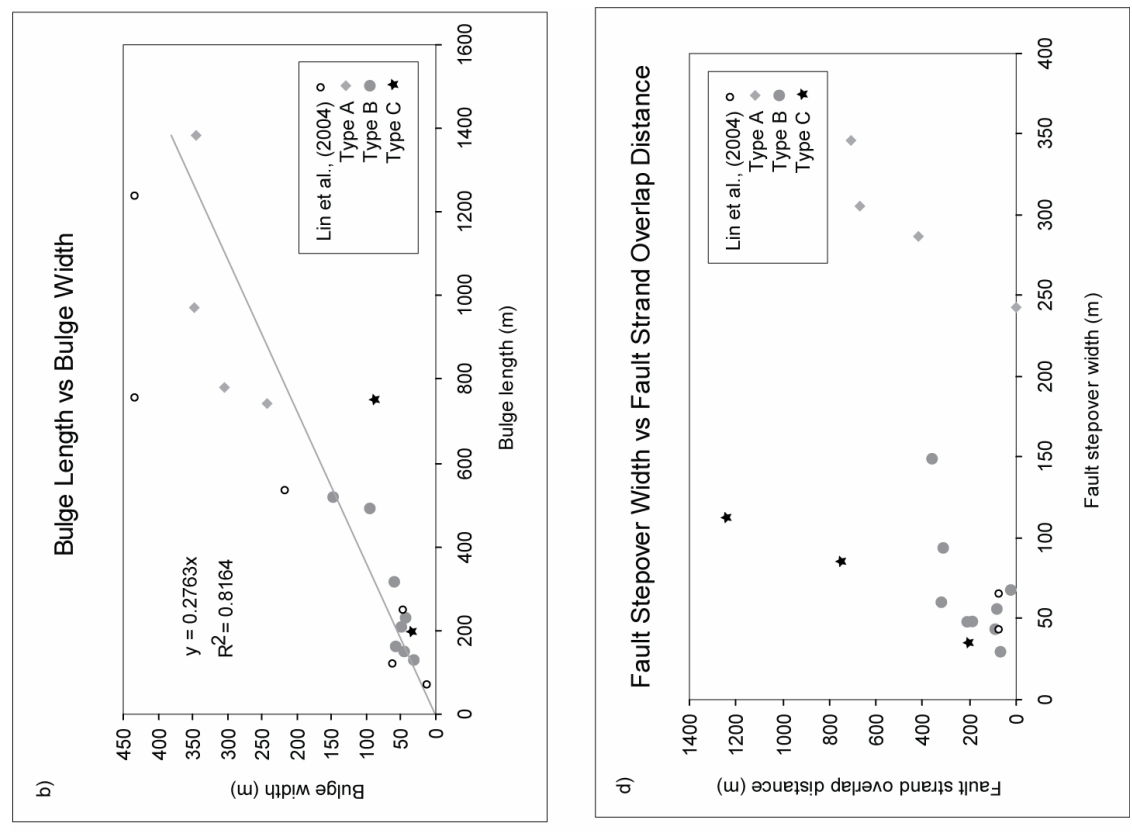

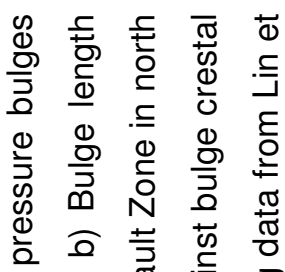

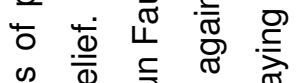

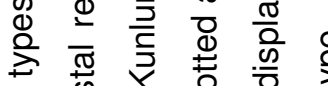

$\geq \frac{\pi}{4}$ 焉

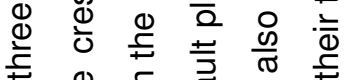

‡

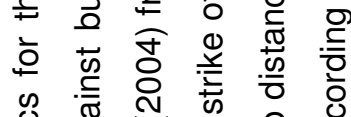

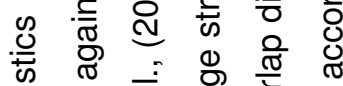

章

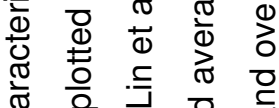
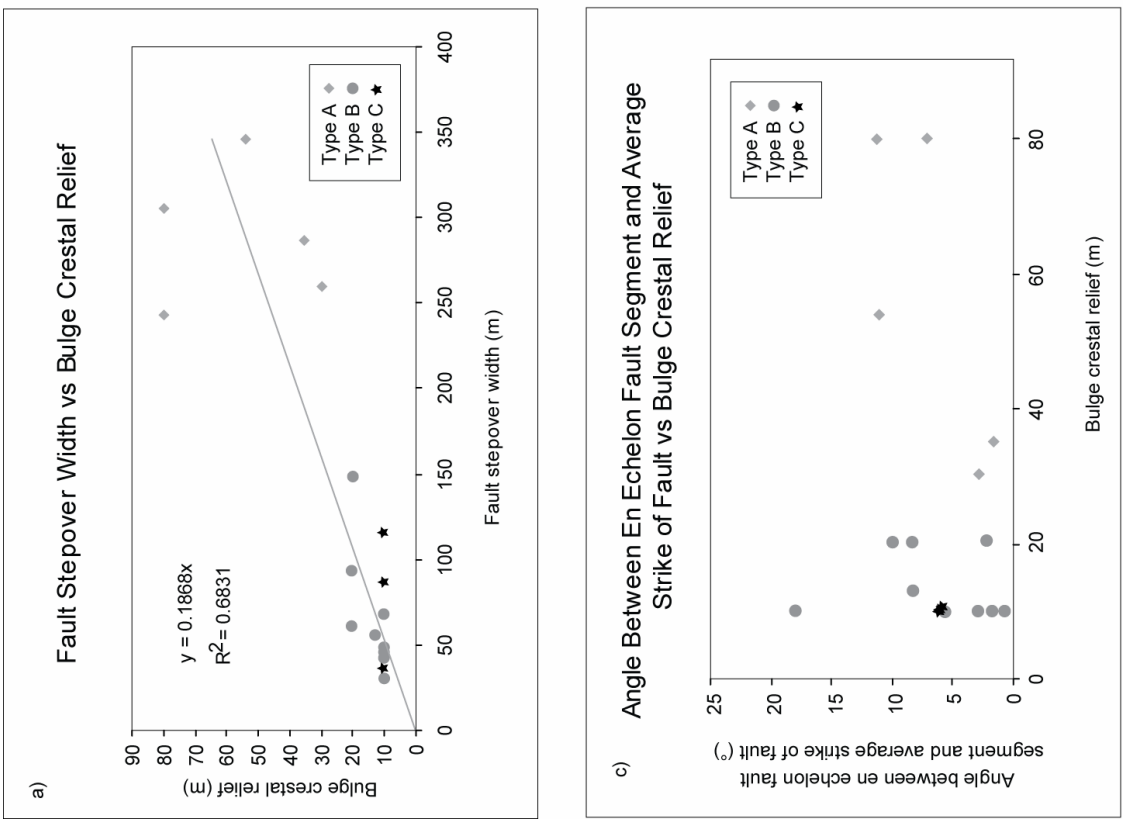

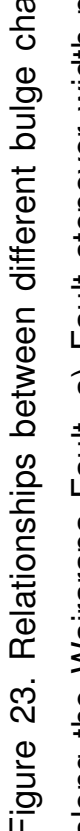

도

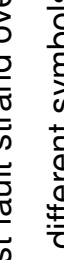

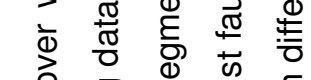

प)

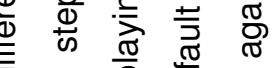

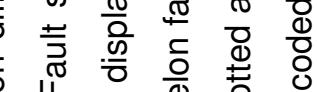

Ф

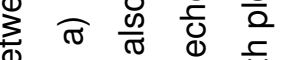

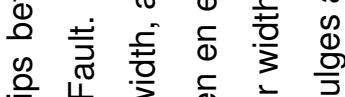

을

등 중 일

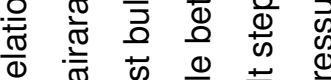

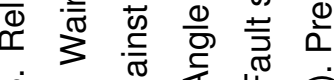

लं

声

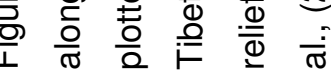



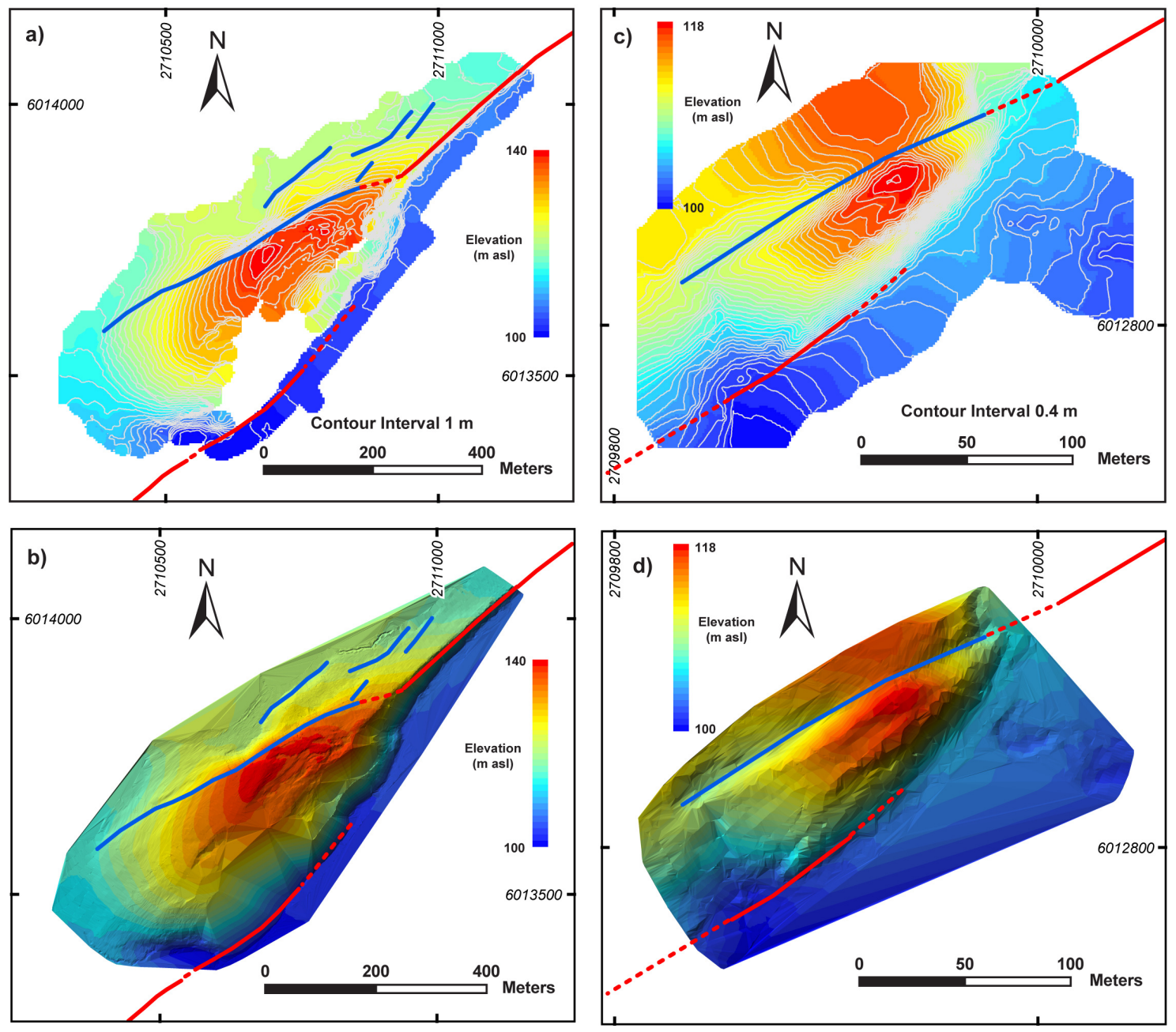

Figure 24. Digital Elevation Models (DEM's) and Triangulated Irregular Networks (TIN's) for two pressure bulges along the Wairarapa Fault near Waiohine River. a) DEM with $1 \mathrm{~m}$ contour interval and b) TIN of large Type A pressure bulge just southwest of Waiohine River. c) DEM with $0.4 \mathrm{~m}$ contour interval and d) TIN of small Type B pressure bulge just southwest of larger Type A bulge just southwest of Waiohine River. Solid lines are observed faults with $\pm 5 \mathrm{~m}$ uncertainty in location, dashed lines are inferred faults with $\pm 10 \mathrm{~m}$ uncertainty, red lines are faults with up-to-the-northwest sense of throw, and bold lines are faults with up-to-the-southeast sense of throw. In the DEM's and TIN's, red corresponds to the areas of highest topographic elevation, and blue corresponds to the lowest. Coordinates are in NZMG. 


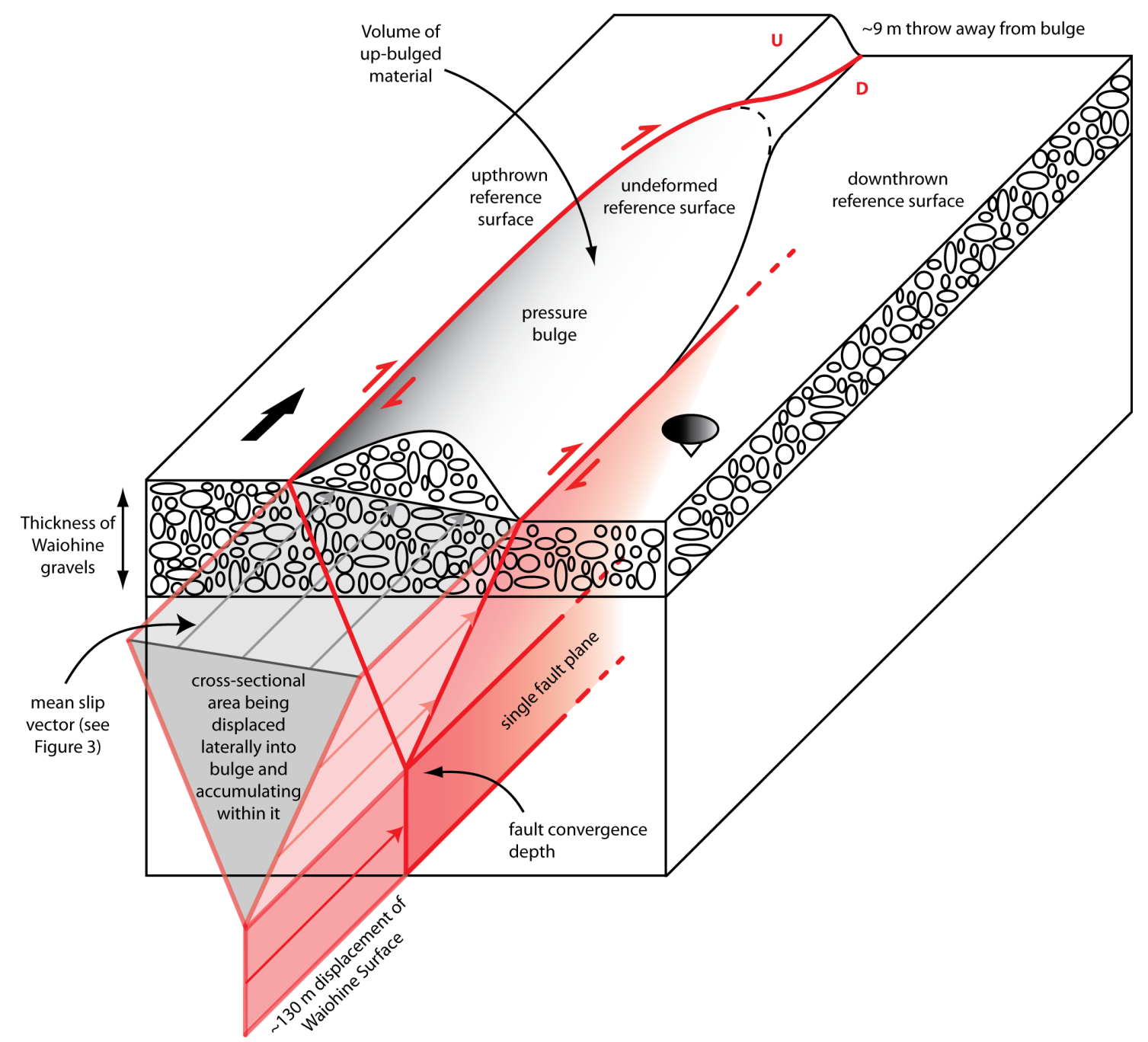

Figure 25. 3D diagram illustrating the method of pressure bulge volume calculation and estimation of fault convergence depth. Fault convergence depth calculation follows similar methodology to that of Groshong (1994). The cross section is drawn perpendicular to the local slip vector, on an azimuth of $\sim 049^{\circ}$. The volume of bulge is calculated relative to two different possible undeformed reference surfaces. These are the average elevation of terrace on upthrown side and on the downthrown side of fault. The calculations yield minimum and maximum estimates of the volume of up-bulged material, respectively. Averaging the two volumes to obtain a mean volume assumes a uniformly sloping reference surface. Using the calculated volume and the known dextral displacement of the Waiohine surface since its abandonment $(\sim 130 \mathrm{~m})$ we approximate the cross-sectional area being displaced laterally into the bulge to a triangle, to find the convergence depth and the mean dip of the two fault strands in the stepover. This depth is compared to the thickness of the Waiohine terrace gravels (max $\sim 30 \mathrm{~m}$ at Waiohine River), to determine if the faults converge at the base of the gravels, or well within basement. 
In the computer mapping program ArcGIS, we produced Digital Elevation Models (DEM's) and Triangulated Irregular Networks (TIN's) (defined in Appendix A6) from the (RTK GPS points (Appendices A5 \& A6) collected at the two pressure bulges (Figure 24ad). We use these DEM's and TIN's to calculate the volume of each bulge relative to above) the undeformed surface of the Waiohine terrace. For this we use the average elevation of the Waiohine surface on the upthrown and downthrown sides of the fault calculated from RTK GPS points collected on both sides of the Wairarapa Fault well away from the bulges (Figure 25). The "excess" volume of the bulge raised above the mean elevation of the Waiohine surface on the upthrown side of the fault provides a minimum volume estimate of the bulge, whereas the excess volume of the bulge raised above the mean elevation of the Waiohine surface on the downthrown side of the fault provides a maximum estimate as it assumes that there is no throw on the fault and all vertical deformation is attributed to the pressure bulge (Table 5). The reference surfaces are gradually sloping southeast with a gradient of $\sim 0.01$ (Section 3.3), however, because we have calculated the average elevations of each reference surface, the gradient does not have a significant effect on the calculated volumes.

Calculated in this way, the excess volumes of the bulges provide an estimate of the volume of material that has been shortened and up-bulged by displacement on the faults bounding that volume (Figure 25). The bulge volumes can be divided by the previously estimated dextral displacement on the fault since the abandonment of the Waiohine surface (129 \pm $18 \mathrm{~m}$ ), which is distributed across the two bounding fault strands. This step in the calculation implies that the slip vector is parallel to the bounding fault segments, which (although not the case where the faults are expressed at the top of the Waiohine gravels) is true at depth, where the bounding faults have a similar strike to the basement fault near the point where they converge into the single basement fault (see Section 3.8.4). This quotient provides an estimate of the cross sectional area that is being deformed into a given pressure bulge (Figure 25) during each slip increment.

We characterise the faults bounding a pressure bulge as forming a simple downwardpointing triangle, with the width on the surface of the bulge approximating the distance between the two fault strands that bound the bulge (Figure 25). The distance between the bounding fault strands is not constant along the length of the bulge. Using the crosssectional area of the triangle (calculated above) and the maximum fault stepover width, we calculate the approximate depth at which the faults bounding each of the pressure bulges converge (Figure 25, Table 5). Minimum and maximum convergence depths are calculated 
Table 5. Input values used in volume calculations at the two pressure bulges along the Wairarapa Fault, and the resulting fault convergence depths, and fault dip angles. The two pressure bulges include large Type A bulge just southwest of Waiohine River, and small Type B bulge just southwest of larger bulge.

\begin{tabular}{|c|c|c|}
\hline Variable & Large Type A Bulge & Small Type B Bulge \\
\hline Average elevation of upthrown terrace ( $\mathrm{m}$ asl) & 115 & 113 \\
\hline Average elevation of downthrown terrace ( $m$ asl) & 106 & 104 \\
\hline Volume of bulge above upthrown terrace $(\mathrm{min})\left(\mathrm{m}^{3}\right)$ & $2,122,854$ & 5,155 \\
\hline Volume of bulge above downthrown terrace $(\max )\left(\mathrm{m}^{3}\right)$ & $4,178,678$ & 53,386 \\
\hline Average volume of bulge $\left(\mathrm{m}^{3}\right)$ & $3,150,766$ & 29,271 \\
\hline Stepover distance $(\mathrm{m})$ & 287 & 55 \\
\hline Maximum fault convergence depth $(\mathrm{m})$ & 265 & 17.6 \\
\hline Minimum fault convergence depth $(\mathrm{m})$ & 101 & 1.3 \\
\hline Average fault convergence depth $(\mathrm{m})$ & 170 & 8.3 \\
\hline Bounding fault dip angle $\left(^{\circ}\right)$ assuming one fault is vertical & 30 & 9 \\
\hline Bounding fault dip angle $\left({ }^{\circ}\right)$ assuming faults have equal dips & 50 & 17 \\
\hline
\end{tabular}


for each bulge using the minimum and maximum volumes and maximum and minimum dextral displacements, respectively (Table 5). We also calculate an average fault convergence depth for each pressure bulge from the average volume and average dextral displacement of the Waiohine surface (Table 5). Using the maximum fault stepover width in this calculation implies that the range of convergence depths calculated for each bulge represent minimum estimates. It is likely that as the stepover distance between faults bounding a bulge decreases, the convergence depth of those faults also decreases, however the above calculation provides a simple first order approximation by which we can estimate fault convergence depths. The fault convergence depths calculated for each bulge do not require prior knowledge of the dips of the downward converging faults, as the convergence depth must be equal to the area of the triangle divided by half of the stepover. Using trigonometry, the dips of the bounding faults above the average fault convergence depth are calculated for each pressure bulge, assuming firstly that the faults have equal dips, and secondly, that one fault dips vertically (i.e. the other fault dip is a maximum estimate) (Table 5).

The calculated fault convergence depth for the large Type A pressure bulge just southwest of Waiohine River (Figure 24a \& b) is $\sim 170 \mathrm{~m}$ (minimum of $\sim 100 \mathrm{~m}$, maximum of $\sim 260$ m) (Table 5), indicating that the two main faults bounding this bulge converge well beneath the base of the Waiohine aggradation gravels (inferred to be no more than $\sim 30 \mathrm{~m}$ thick at Waiohine River). At this same bulge, Grapes and Wellman (1988) calculated a much shallower bulge depth extent of $\sim 60 \mathrm{~m}$, although a methodical description of this calculation is not provided. The calculated fault convergence depths for the smaller Type B pressure bulge further southwest from the larger bulge (Figure $24 \mathrm{c} \& \mathrm{~d}$ ) is $\sim 8 \mathrm{~m}$ (minimum of $\sim 1 \mathrm{~m}$, maximum of $\sim 18 \mathrm{~m}$ ) (Table 5), suggesting that the two main faults bounding this bulge may converge approximately near the base of the Waiohine aggradation gravels. Assuming that the two faults bounding each pressure bulge have equal dips, the faults at the Type A bulge have dips of $\sim 50^{\circ}$, and the faults at the Type B bulge have dips of $\sim 17^{\circ}$ (Table 5), whereas under the assumption that one bounding fault dips vertically, the other bounding fault at the Type A bulge has a dip of $\sim 30^{\circ}$, and fault at the Type B bulge has a $\operatorname{dip}$ of $\sim 9^{\circ}$ (Table 5). 


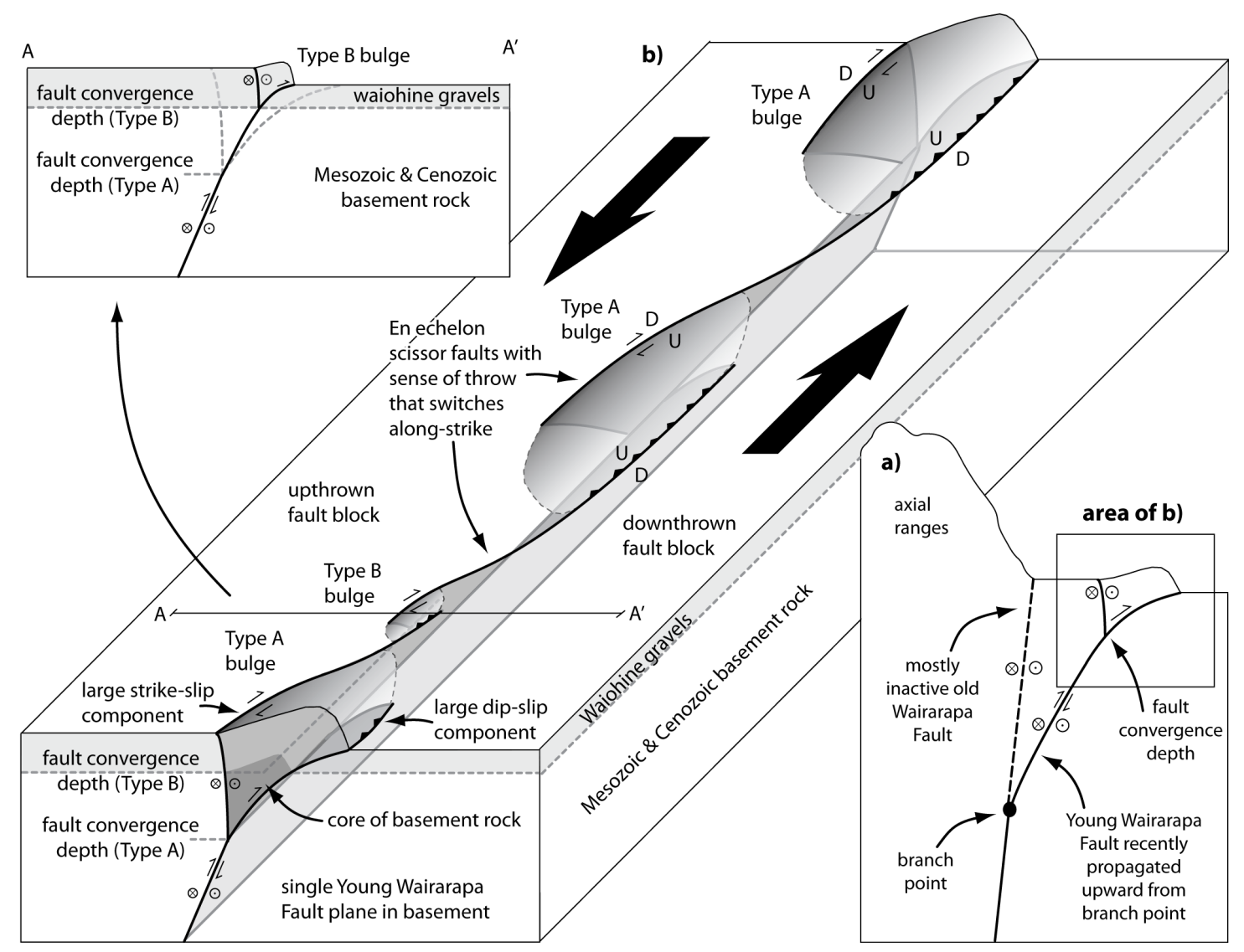

Figure 26. Schematic interpretation of 3D fault geometry along the Wairarapa Fault. a) shows newly proposed young Wairarapa Fault branching off the old Wairarapa Fault closer to the range front. Grey box indicates area of b). b) shows helicoidal 3D geometry and hierarchy of faults in the near surface. Faults bounding Type A bulges branch off a single dipping fault within basement rock, while faults bounding Type B bulges branch off the Type A fault segment to which they belong, at or near the base of the Waiohine gravels. At the surface, en echelon scissor faults display variable sense of throw along-strike. Faults in the upthrown fault block accommodate a greater proportion of strike-slip displacement, while faults in the downthrown block accommodate a greater proportion of dip-slip displacement. Bulges are asymmetric in map view and in cross section. Cross section at the end of the b) shows that the core of Type $A$ bulges is deformed basement. Cross section A-A' is through a smaller Type B bulge, showing that bulge deformation is limited to the gravels. The Type $B$ faults branch off a Type $A$ fault along its central part (i.e. in between Type A bulges), where the dip of the Type A fault is between that of the dashed dips that occur at either end of the fault segment. 


\subsection{Discussion}

\subsubsection{Upward propagation of a young Wairarapa Fault into the Wairarapa Valley}

The currently active Wairarapa Fault zone may represent an immature structure that has only recently propagated upward to the surface, perhaps as a splay from an older, and simpler, northwest-dipping Wairarapa Fault at depth. This young fault is proposed to have branched out eastwards from an older Wairarapa Fault along the very eastern edge of the Rimutaka Ranges, perhaps in response to topographic loading of the ranges, in a similar way to the propagation of a thrust belt (Figure 26a). By propagating eastward, this young fault would inherit a steep northwest dip, as is supported by previously published gravity and magnetotelluric fault dip studies (Hicks \& Woodward, 1978; Von Borstel \& Ingham, 2004, described in section 3.2). Several laterally continuous fault strands with diffuse scarps were mapped by Rodgers and Little (2006) on the topographically higher, western side of the fault zone closer to the Rimutaka Range front, which they inferred to be inactive structures. In support of this model, we identified these structures in aerial photos, and a few additional faults northwest of the fault zone on the section of the fault between Waiohine River and Featherston (Figure 20, Plates 3, 5, 9, \& 10).

The growth and abandonment of thrust sheets is controlled by erosion at the thrust front. Active growth of thrust sheets occurs when and where the thrusts are protected from active erosion, for example, immediately following a glacial period when thick alluvial gravels are deposited along the range front (Norris \& Cooper, 1997). Without active erosion and efficient sediment transport away from the range front, eroded sediments build up adjacent to the fault, promoting failure of the footwall and the development of a forward-propagating low-angle thrust (Norris \& Cooper, 1997). With rapid erosion rates at the range front, continued movement on the existing thrust continues, without the forward propagation of a new thrust (Norris and Cooper, 1997). The erosional control on the structural evolution of a transpressional thrust complex on the Alpine Fault is described by Norris and Cooper (1997), where active erosion of the Southern Alps and efficient removal of eroded material by the Tasman Sea has prevented the development of extensive lowangle thrust sheets to the west of the southeast-dipping Alpine Fault. Along the Wairarapa Fault, there has not been such rapid erosion of the Tararua and Rimutaka Range front or effective removal of eroded sediments, promoting the propagation of a younger thrust fault eastwards into the Wairarapa Valley, ahead of the older northwest-dipping fault plane. 
The propagation of this young Wairarapa Fault through the previously unfaulted upper crust has important implications for the applicability of the different types of analogue models (described in section 3.6.1). For a detailed comparison of the boundary conditions and surface deformational structures at the Wairarapa Fault and the four main types of analogue models (section 3.6.1) see Appendix D. We infer that analogue models of deformation in the previously unfaulted overburden above a single strike-slip to slightly reverse-oblique basement fault, rather than a wide distributed deformation zone at depth (e.g. Naylor et al., 1986; Richard, 1991; Richard et al., 1995), are the most applicable to the natural case of the Wairarapa Fault at two different scales, though this situation is certainly not correct in detail.

At the scale of Type A faults, the upward propagation of this newly formed, youngest branch of the Wairarapa Fault implies that the previously unfaulted upper crust above this splay may have once been analogous to the initially unfaulted overburden above the basement fault discontinuity in the analogue models (section 3.6.1). It is in this sense that these models might approximate the formation of the larger Type A faults and bulges that our volumetric calculations indicate are much more deep-seated than the Waiohine gravels. These basement strike-slip to oblique-slip models impose a discontinuity between the baseplate and the non-cohesive overburden that, of necessity, becomes coincident with the point of convergence of newly developed faults in the overburden into the basement fault discontinuity. In nature, along the Wairarapa Fault, such a discontinuity seems unlikely at the depth of Type A fault convergence. In section 3.8.4, we speculate as to what other factors may have led to the branching of the Wairarapa Fault at this depth.

Potentially similar to many of the analogue models, a stratigraphic discontinuity does exist between overlapping Waiohine gravels and the much older and presumably more strongly faulted Cenozoic/Mesozoic basement, at the scale of Type B faults. Our volume calculations suggest that depth at which Type B overburden faults converge with one another is similar to the depth of the base of the Waiohine gravels. These basement strikeslip to oblique-slip models are therefore applicable to the formation of Type B fault segments above a pre-exiting (Type A) basement fault discontinuity along the Wairarapa Fault. The $\sim 230^{\circ}$ azimuth of slip at the Wairarapa Fault implies a convergence angle oriented $\sim 3^{\circ}$ clockwise to the average strike of the Wairarapa Fault (Figure 17). The reverse-oblique strike-slip model of Richard et al., (1995) implies that the fault pattern generated for fault convergence angles as high as $\sim 7^{\circ}$ on a $45^{\circ}$ dipping basement fault (section 3.6.2) strongly resemble those generated by pure strike-slip models, making both 
pure strike-slip and slightly-oblique slip models applicable to the natural case of the Wairarapa Fault.

\subsubsection{Depth of fault segmentation and deformational bulging along the Wairarapa Fault}

With insight from our volumetrically calculated fault convergence depths (section 3.7.2), we here attempt to explain the differences in depth extent and origin of the Type A and B pressure bulges. The calculated fault convergence depth at the larger Type A pressure bulge (average of $\sim 170 \mathrm{~m}$ ) is much deeper than the base of the Waiohine gravels. Bounded by long en echelon Type A fault segments and coinciding with large stepovers (250-350 m), we infer that all Type A bulges converge into a single fault plane within Cenozoic/Mesozoic basement (as is demonstrably the case for the large bulge just south of Waiohine River), and that these deep-seated structures have not formed in response to distributed deformation that is largely confined to the recently deposited Waiohine gravels. The deepseated nature of Type A bulges is supported by their spatial distribution. For example, they are not localised at the point where major rivers exit the Rimutaka and Tararua Ranges and have deposited especially thick aprons of Waiohine gravels, but are also located between such rivers and where the thickness of Waiohine gravel cover is demonstrably thin $(<10$ m). In summary, we infer that an en echelon array of R-faults separated by large stepovers already existed within basement rock prior to deposition of the Waiohine gravels. Early development of the large Type A bulges thus probably occurred in these stepover regions also prior to the gravel deposition. This implies that the bulges probably involve basement in there cores, as is supported by Grapes and Wellman's (1988) observation that Mesozoic greywacke basement rock is exposed in the streams that cross-cut the large Type A bulge just southwest of Featherston (Figure 22h). The inferred bulging of the basement rock could be further verified by the identification of an angular unconformity between basement strata or older terrace gravels, and the younger Waiohine gravels, and by onlap of the Waiohine gravels against the previously deformed terrace gravels or basement rock.

The fault convergence depth that we calculated volumetrically at the smaller Type B bulge $(\sim 8 \mathrm{~m})$ is on the same order as the inferred depth of the Waiohine gravel sequence at that site $(<10 \mathrm{~m})$. The gravels are likely to be shallower there than at the larger Type A bulges, as this site is further from the mouth of the Waiohine River, and a similar distance from the mouth of the Tauwharenikau River. This fault convergence depth suggests that faults bounding that bulge may have branched outward at the gravel-basement interface as they propagated up from the existing Type A fault in basement, due to the difference in material 
properties of the two layers (faulted bedrock below; originally unfaulted, unconsolidated Waiohine gravels above). We infer that the en echelon Type B faults at all Type B bulges associated with smaller stepovers $(30-150 \mathrm{~m})$, branch at or near the base of the Waiohine gravels at similarly shallow depths, and that these bulge structures are relatively surficial in nature and confined to the Waiohine gravels. The variations in size of Type B bulges (bounding fault stepover widths of 30-150 m) along the Wairarapa Fault presumably reflect changes in the thickness of the Waiohine gravels beneath each bulge. A similar technique involving the amount of shortening and the volume per unit length of each bulge was used to calculate fault convergence depths for different sized pressure bulges along the Leirubakki Fault in South Iceland (Bergerat et al., 2003). The calculated fault convergence depths indicate that en echelon faults bounding the bulges converge into a single fault plane at two main levels. The transitions between en echelon fault systems at different depths are interpreted to reflect the presence of local decollements between basalt layers (Bergerat et al., 2003).

\subsubsection{Finite displacement on the current strand of the Wairarapa Fault}

The immaturity of the Wairarapa Fault is reflected by its highly segmented surface trace. In this section, we compare the pattern of surface faults along the Wairarapa Fault with those predicted by various analogue models, to assess the stage of fault evolution of the Wairarapa Fault, and estimate the finite displacement on the Wairarapa Fault at depth. Only the Type A fault segments and bulges that penetrate the basement rock will be assessed. The stage of a strike-slip fault's evolution is characterised by the type of faults that have formed, their orientation with respect to the basement fault or shear direction, and their degree of connectivity. Fault zones are characterised by discontinuous traces during their initial stages of development, and increasing displacement along these faults removes such discontinuities, smoothing the fault plane (Wesnousky, 1988). The number of stepovers per unit length along major strike-slip fault traces has been shown to be a smoothly decreasing function of cumulative geological offset (e.g. Wesnousky, 1988). The total basement displacement required to reach a particular stage of fault evolution is displayed in Table 6 and Figures 27a-d for various analogue models (e.g. Casas et al., 2001; Naylor et al., 1986; Richard, 1991; Schreurs, 2003; Schreurs \& Colletta, 1998). The displacements applied to the analogue models at each stage of their fault evolution are scaled up to nature using the scaling factors described in the corresponding papers. We also provide displacements normalised to the fault convergence depth, in an endeavour to account for the difference in fault convergence depth at the Wairarapa Fault (section 3.8.2) and the much greater scaled-up convergence depths implied by the analogue models. This 


\begin{tabular}{|c|c|c|c|c|c|c|c|c|c|c|c|c|c|c|c|c|c|c|}
\hline 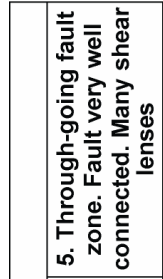 & $\stackrel{\circ}{\frac{\circ}{N}}$ & $\hat{o}$ & & & & & & 各 & $\stackrel{\circ}{\circ}$ & ০̊ & $\begin{array}{l}\stackrel{\hat{g}}{+} \\
\dot{q}\end{array}$ & 怘 & 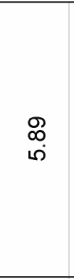 & $\left.\begin{array}{l}0 \\
0 \\
i \\
i\end{array}\right)$ & & & & \\
\hline 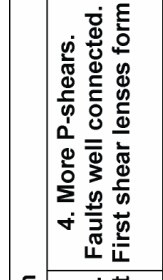 & 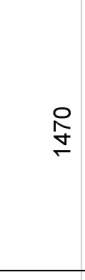 & 昌 & $\stackrel{\stackrel{\circ}{\circ}}{\stackrel{\circ}{9}}$ & 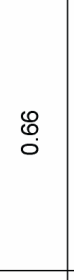 & $\stackrel{\circ}{\frac{O}{+}}$ & 岕 & & 怘 & $\stackrel{0}{0}$ & 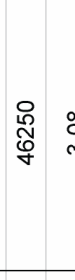 & 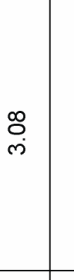 & & & & & & & \\
\hline 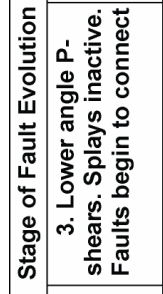 & 吕 & 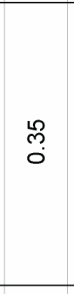 & $\begin{array}{l}\stackrel{0}{0} \\
\stackrel{6}{6}\end{array}$ & 㞻 & & & & 总 & 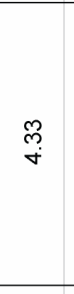 & $\begin{array}{l}\stackrel{0}{R} \\
\text { Nh } \\
N\end{array}$ & مִ & 离 & $\stackrel{\leftrightarrow}{\stackrel{\leftrightarrow}{*}}$ & 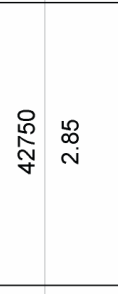 & & & & \\
\hline 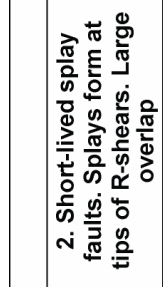 & 导 & $\stackrel{\substack{N \\
0}}{0}$ & 尺్ & 龸 & & & & 怘 & $\stackrel{\circ}{m}$ & & & & & & : & $\stackrel{\mathscr{N}}{\mathrm{N}}$ & 总 & $\stackrel{\nabla}{N}$ \\
\hline 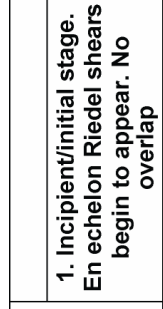 & ర్లి & $\bar{N}$ & $\stackrel{ }{\stackrel{ }{ }}$ & 命 & & & & 怘 & $\stackrel{\leftrightarrow}{\stackrel{\leftrightarrow}{-}}$ & & & $\begin{array}{l}\stackrel{\circ}{\circ} \\
\stackrel{\Omega}{\sigma} \\
\stackrel{5}{*}\end{array}$ & 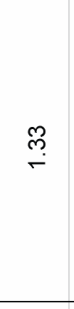 & $\stackrel{\circ}{\stackrel{\leftrightarrow}{\circ}}$ N & & & & \\
\hline 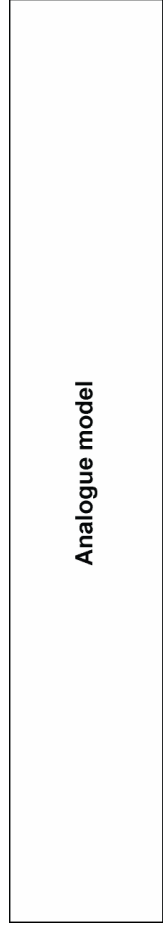 & 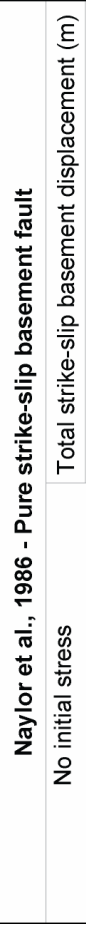 & 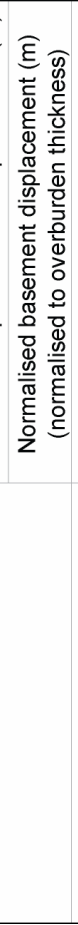 & 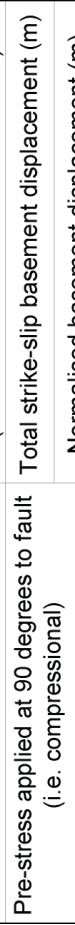 & 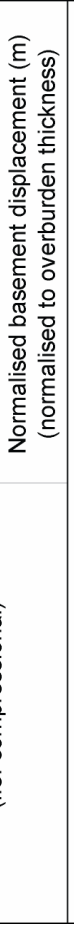 & 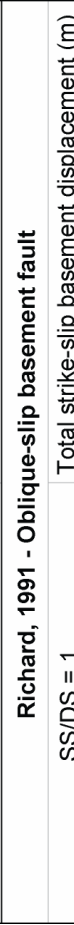 & 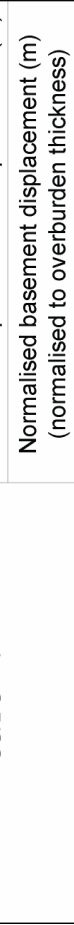 & 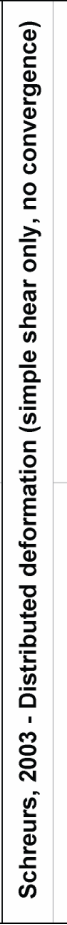 & 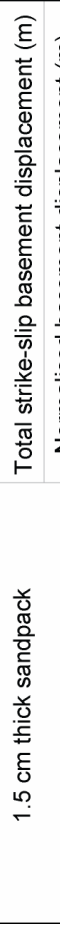 & 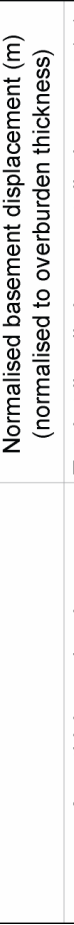 & 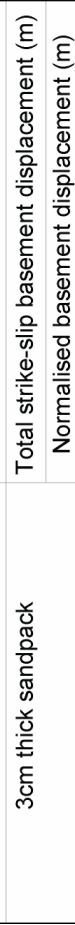 & 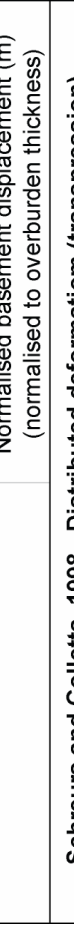 & 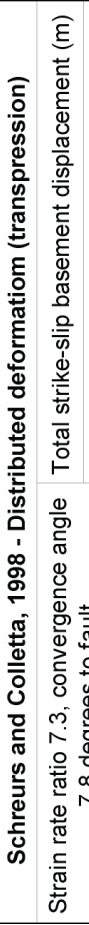 & 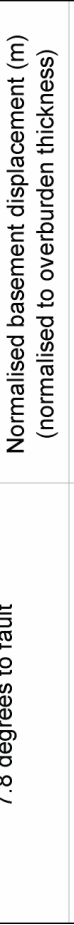 & 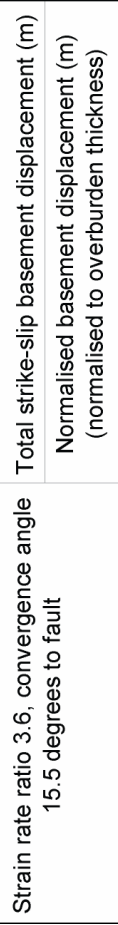 & 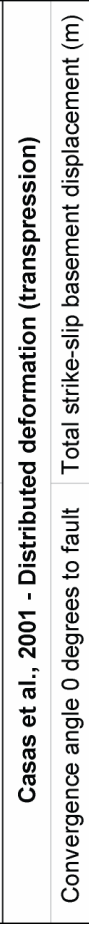 & 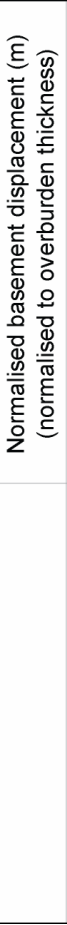 & 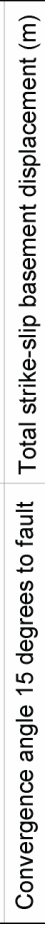 & 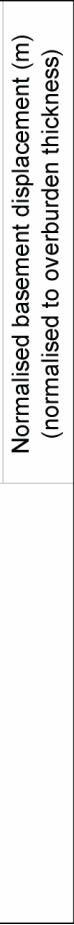 \\
\hline
\end{tabular}



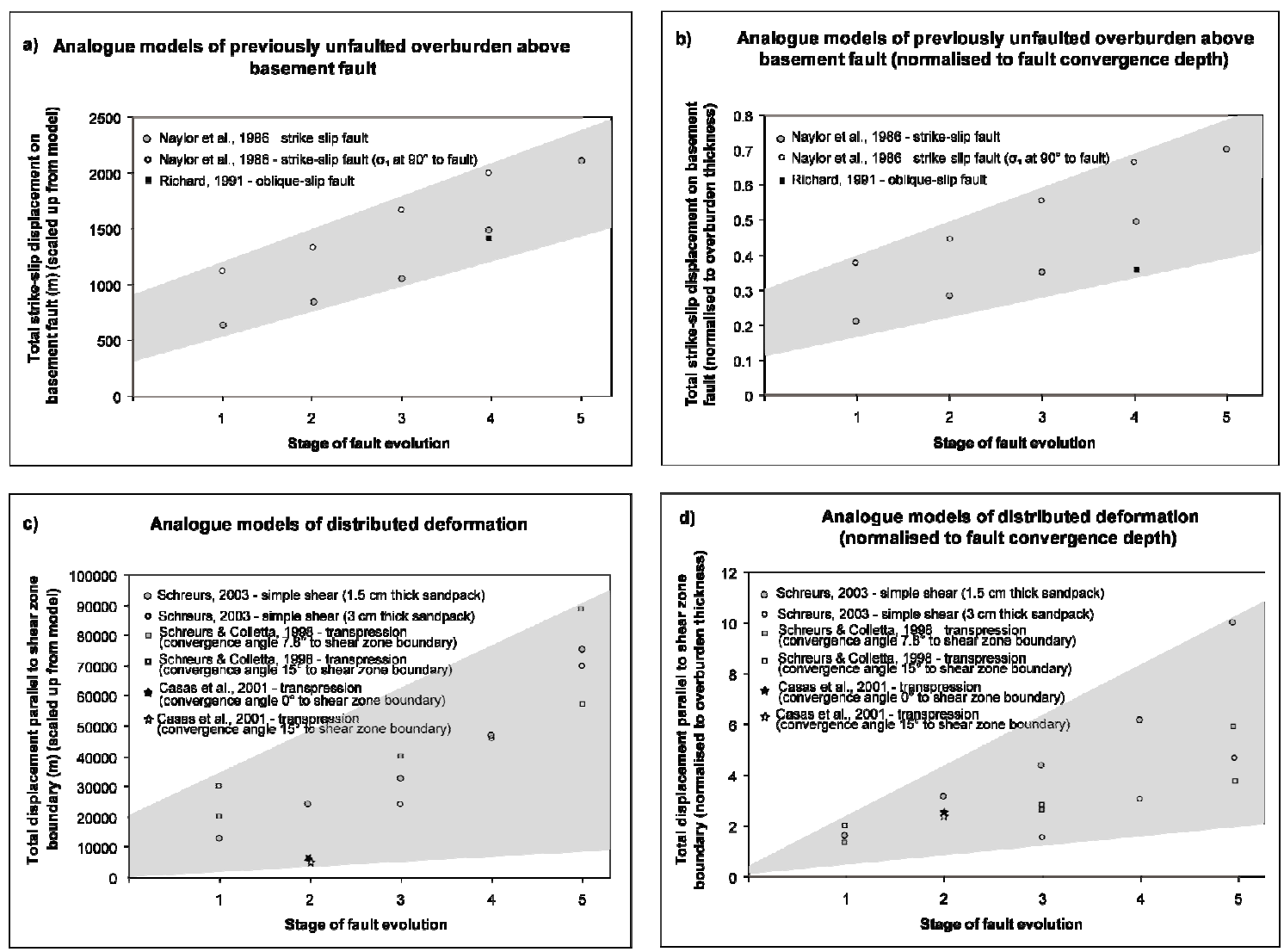

Figure 27. Stage of fault evolution as a function of total strike-slip or shear displacement for different analogue models. a) Total strike-slip displacement plotted against stage of fault evolution for analogue models of deformation of a previously unfaulted overburden above a single basement fault. b) Total strike-slip displacement normalised to fault convergence depth plotted against stage of fault evolution for analogue models of deformation of a previously unfaulted overburden above a single basement fault. c) Total displacement parallel to shear zone boundary plotted against stage of fault evolution for analogue models of distributed deformation. d) Total displacement parallel to shear zone boundary normalised to overburden thickness plotted against stage of fault evolution for analogue models of distributed deformation. Naylor et al., (1986) model with $\sigma^{1}$ at $90^{\circ}$ to fault models a compression applied to a basal rubber sheet above the fault before strike-slip motion is induced. The models of Naylor et al., (1986) and Richard et al., (1995) are used to estimate the total displacement on the young branch of the Wairarapa Fault, as these models have the most applicable boundary conditions to the Wairarapa Fault. The displacements required to reach a particular stage of fault evolution are two orders of magnitude larger than those of the basement fault models, and are not used to estimate the total displacement on the young Wairarapa Fault. 
assumes a linear relationship between the basement displacement at which a particular fault pattern is observed and the fault convergence depth (i.e. if the convergence depth is doubled, it would take twice as much displacement on the basement fault to reach the same stage of fault evolution).

By comparing the type of faults, their orientations and the degree of continuity of the segmented surface pattern of Type A faults that has formed along the Wairarapa Fault with those exhibited by the most applicable analogue models of Naylor et al., (1986) and Richard (1991), we qualitatively assess the stage of fault evolution reached by the Wairarapa Fault in basement below the base of the Waiohine gravels. The total displacements required on these strike-slip to oblique-slip basement fault models to reach a particular stage of fault evolution, are two orders of magnitude smaller than the displacements implied by models of distributed deformation (Table 6, Figures 27a \& c). Based on the high degree of discontinuity and overlap of the observed en echelon Type A fault (R-fault) segments, the Wairarapa Fault exhibits the characteristics of a strike-slip fault that is in an early stage of its evolution (equivalent to stage 2 or 3 in Table 6 and Figures 27a \& b).

Due to the lack of geologic markers displaced across the Wairarapa Fault, scaling of the modelled displacement up to nature allows us to qualitatively estimate the finite displacement that has occurred on this branch of the Wairarapa Fault. Estimating the displacement in this way assumes that the long wavelength pattern of Type A faults at the surface of the Waiohine gravels has formed in response to the total basement fault displacement, and not just the displacement that has occurred since the Waiohine surface's abandonment, as considered previously. We believe this assumption is valid (and that the pattern of Type A faults at the surface of the Waiohine gravels directly reflects the fault pattern at the surface of the basement rock beneath the Waiohine gravels) for three reasons; for Type A bulges, we have shown that the fault stepovers are more deep-seated than the Waiohine gravels and that the surface of the basement rock was probably segmented prior to deposition of the Waiohine gravels (section 3.8.2); the segmented basement faults would have likely propagated up quickly through the gravels following their deposition due to the shallow thickness of the Waiohine gravels, and; the surface pattern of faults is more developed than could be explained by scaled analogue models with only $\sim 130 \mathrm{~m}$ of strike-slip displacement on the basement fault (amount of displacement since the deposition of Waiohine gravels). The dextral displacement of the Waiohine surface of $\sim 130 \mathrm{~m}$ (section 3.3) provides a minimum estimate for the total displacement of the young Wairarapa Fault at depth. 
According to the analogue models of Naylor et al., (1986) and Richard (1991), stages two and three of a faults evolution correspond to an approximate finite displacement on the basement fault of $\sim 800 \mathrm{~m}$ to $\sim 1700 \mathrm{~m}$ (Table 6, Figure 27a). These models have scaled fault convergence depths of between $3 \mathrm{~km}$ and $4 \mathrm{~km}$ (equal to the overburden thickness), while the fault convergence depth for Type A faults along the Wairarapa Fault is estimated as only $\sim 100-260 \mathrm{~m}$ (section 3.7.2). These displacements represent maximum estimates, as they assume a greater fault convergence depth than has been calculated for the Wairarapa Fault, and a greater fault convergence depth would require a greater total basement fault displacement to reach a particular stage of a faults evolution.

We scale the basement displacements normalised to overburden thickness (for stages two and three of the faults evolution) in these analogue models, with the fault convergence depth for Type A faults along the Wairarapa Fault (Table 6, Figure 27b). Based on comparisons with the modelling studies, one would infer an approximate finite displacement on the basement fault of $\sim 20 \mathrm{~m}$ to $\sim 160 \mathrm{~m}$. Compared with the known displacement on the Wairarapa Fault since the deposition of the Waiohine gravels $(\sim 130$ $\mathrm{m})$, these displacements suggest that either the displacement on the basement fault is approximately equal to that recorded at the surface, or that there is not a linear relationship between fault convergence depth and the basement displacement at which a particular stage of fault evolution is observed. The maximum finite displacement inferred for this branch of the Wairarapa Fault, together with a new Late Quaternary dextral slip rate estimate for the central Wairarapa Fault of $12.0 \pm 3.5 \mathrm{~mm} / \mathrm{yr}$ (Chapter 2 this thesis, and Carne et al., manuscript in prep) implies an age of inception for this branch of the Wairarapa Fault that is some time after $\sim 100-250 \mathrm{ka}$, supporting the inference that it is a young fault that has only recently propagated upward from an older Wairarapa Fault at depth. The inception age for this young branch of the Wairarapa Fault does not appear to coincide with any known local change in plate motion resulting in increased contraction, or the initiation of any other faults in the Wairarapa region (e.g. Nicol et al., 2002). As discussed in section 3.8.1, inefficient removal of sediment away from the range front may have promoted the propagation of the young Wairarapa Fault branch away from the range front, which would be most likely to occur at the end of a major glaciation. The inception age calculated for this young Wairarapa Fault branch is outside of the resolution of the glacial cycles that occurred during this period, and so the fault propagation cannot be directly attributed to any particular climatic event. 


\subsubsection{A model for the 3D geometry of the Wairarapa Fault}

In this section, we present a model for the 3D fault geometry of the Wairarapa Fault in the near surface (Figure 26). The 3D model combines our observations of surface faults and deformational bulges along the Wairarapa Fault with the convergence depths calculated for Type A and B faults, and the surface and 3D fault geometry predicted by analogue models of basement-induced strike-slip to oblique-slip faulting (e.g. Naylor et al. 1986; Richard et al., 1995; Ueta et al., 2000), as determined from cross sections and X-ray tomography of sandbox analogue models. The model describes a hierarchy of en echelon fault structures, where the different types of deformational bulges have developed in the stepover regions between fault segments belonging to different levels of the fault system. The relative timing of bulge development is also discussed with particular reference to the timing of deposition of the Waiohine gravels.

Our model for the 3D geometry of the oblique-slip Wairarapa Fault zone (Figure 26) is characterised by a hierarchy of en echelon fault segments that merge with the single northwest-dipping, oblique-slip Wairarapa Fault plane at depth. Along the Wairarapa Fault, a series of 2-7 km long en echelon Type A fault segments (R-faults) separated by 250-350 m wide stepovers (associated with Type A bulges) have formed. These Type A fault segments strike at an angle of $2^{\circ}-11^{\circ}$ (average of $\sim 7^{\circ}$ ) clockwise to the average strike of the Wairarapa Fault, and have a sense of vertical displacement that switches across the trace of the basement fault. They also display an across-strike asymmetry and partitioning of slip where they bound deformational bulges (refer to section 3.8.5). Presumably, these Type A faults exhibit a helicoidal ('ship-body') 3D geometry (Figure 26), and appear as convexupward palm-tree structures in cross section, as predicted above steeply dipping reverseoblique strike-slip faults (Naylor et al., 1986; Richard et al., 1995; Sylvester, 1988; Ueta et al., 2000; Wilcox et al., 1973). At each overlapping fault stepover, slip decreases towards the tip of each fault segment, where it is accommodated by slip on the overlapping fault strand. The faults in these structures dip gently at the surface and steepen progressively at depth branching onto a single sub-vertical fault zone (Casas et al., 2001). Assuming from the Type A bulge asymmetry (section 3.8.5) that the northwest bounding Type A faults dip sub-vertically, the southeast bounding faults are interpreted to dip $\sim 30^{\circ}$ northwest (calculated from fault convergence depth and stepover width in section 3.7.2). Along the central section of each fault segment, displacement is fully accommodated on a single fault without assistance from an overlapping segments. Along its central section, each fault must have a dip of between $\sim 90^{\circ}$ and $\sim 30^{\circ}$, which is presumably most similar to the dip of the master fault at depth, allowing that part of the fault segment to fully accommodate 
displacement. The Type A faults are inferred to converge into a single basement Wairarapa Fault plane at depths of $\sim 100-260 \mathrm{~m}$ (Figure 26).

Within these basement penetrating, relatively long Type A fault segments, a series of 500$4000 \mathrm{~m}$ long Type B faults (R-faults) separated by 30-150 m wide stepovers (associated with Type $\mathrm{B}$ bulges) are arranged in an en echelon pattern with respect to the Type A segment in which they occur (Figure 26). These Type B faults strike at an angle of $2^{\circ}-18^{\circ}$ (average of $\sim 6^{\circ}$ ) clockwise to the strike of the higher order Type A fault segment in which they occur, similar to the angle between the Type A fault segments and the average strike of the Wairarapa Fault. They also have a sense of vertical displacement that switches across the trace of the basement fault, and display an across-strike asymmetry and partitioning of slip where they bound deformational bulges (section 3.8.5). These en echelon Type B faults also presumably exhibit a helicoidal 3D geometry (also convex-upward palm-tree structures in 2D), but are interpreted to converge into a single dipping Type A fault plane at depths of $\sim 1-18 \mathrm{~m}$; that is, within or at the base of the recently deposited Waiohine gravels (Figure 26). Assuming from the asymmetry of the Type B bulges (section 3.8.5) that their northwest bounding Type B faults dip sub-vertically, the southeast bounding faults are interpreted to dip $\sim 9^{\circ}$ northwest (calculated from fault convergence depth and stepover width in section 3.7.2). The complex nature of a fault zone at the surface often masks a much simpler and direct connection at depths associated with large earthquakes (e.g. San Andreas Fault System, California; Graymer et al., 2007). 3D excavation of faults shows that the stepping geometry of a fault ruptures surface trace may coalesce into a contiguous fault only a few metres down-dip (Sieh, 1984; Yeats, Sieh \& Allen, 1997).

The hierarchy of en echelon structures along the Wairarapa Fault has been observed elsewhere in both natural and experimental settings. Such "Riedel within Riedel" structures have been described for shear zones at shear box and earthquake fault scale by Tchalenko (1970), where the smaller scale structural arrangement of faults is basically the same as that governing the main fault structure. A similar hierarchy of en echelon faults (separated by pressure bulges of various sizes) was observed by Bergerat et al., (2003) along the dextral strike-slip Leirubakki Fault in South Iceland. The exposed surface rupture along that fault contains fractures that range in size over four orders of magnitude. The fractures in all size classes (except the largest one) are arranged in a (clockwise) en echelon pattern relative to the higher-order system that contains them. All the en echelon fault systems are inferred to belong to a single fault plane at depth (Bergerat et al., 2003). 
At Type $\mathrm{C}$ bulges along the Wairarapa Fault, the adjacent en echelon Type B faults almost completely overlap forming enclosed shear lenses, between which, faults resembling lowangle R faults and P-faults have developed (Figures 22d \& m), as is predicted for a later stage of fault evolution by the analogue models (e.g. Naylor et al., 1986). These new Rfaults and P-faults have steeper dips and a less pronounced helicoidal geometry than the Type B faults (R-faults) that they have formed between (Ueta et al., 2000). The Type C bulge just north of Tauwharenikau River (Figure 22d) exhibits the exact same geometry as a fully formed shear lense in the final stage of fault evolution in Naylor et al.,'s (1986) analogue model (Figure 2 of Naylor et al., 1986), suggesting that Type C bulges form along the Wairarapa Fault where the stage of fault evolution is locally higher than at Type A and B bulges.

The surface fault geometry at the Wairarapa Fault is different to that predicted by the analogue models of Naylor et al., (1986) and Richard et al., (1991). In nature (Wairarapa Fault) Type A and B faults strike at a lower angle to the average strike of the higher order fault to which they belong, than the $17^{\circ}-20^{\circ}$ predicted by analogue models for R-fault formation above strike-slip to slightly oblique-slip faults (for densely packed sand according to ideal Coulomb-Mohr behaviour). One explanation for this difference in strike might be the fact that the Type A and B faults converge at a much shallower depth relative to the thickness of the unfaulted sand-pack in modelling studies. If there is less "room" vertically for the surficial sediment to deform, the faults that branch upwards from the basement fault, cannot branch as widely outwards, as would be the case if the convergence depth were much greater (as in the models). The Wairarapa Fault forms a very narrow $(<350 \mathrm{~m})$ fault zone, made up of long en echelon Type A fault segments, in comparison to the wider (1$2 \mathrm{~km}$ ) fault zone made up of numerous shorter faults that is predicted by strike-slip analogue models (e.g. Naylor et al., 1986; Richard et al., 1995). We also attribute these differences to the shallower fault convergence depths at the Wairarapa Fault than implied by most of the analogue models.

The inferred timing of propagation of each type of fault to the surface can be described relative to the timing of deposition of the Waiohine gravels. The young splay of the Wairarapa Fault propagated upward through the upper crust from an older, now mostly inactive Wairarapa Fault at depth (Figure 26a), some time in the past 100-250 ka, long before the deposition of the Waiohine gravels. This young splay in inferred to have propagated up to a depth of $\sim 200 \mathrm{~m}$, where it branched outwards to form a series of en echelon Type A faults (Figure 26). These Type A faults propagated up from $200 \mathrm{~m}$ depth to 
the surface of the basement rock prior to deposition of the Waiohine gravels. Early formation of Type A bulges in the stepover region between adjacent Type A faults therefore, would have occurred in basement rock before Waiohine gravel deposition (Figure 26, section 3.8.2). The up-bulged basement rock was likely to have been eroded prior to deposition of the Waiohine gravels, keeping these bulges at relatively low amplitudes, however very little is known about the level of erosion that these basement sediments were exposed to prior to Waiohine gravel deposition. As described in section 3.8.2, Waiohine gravels are observed directly overlying greywacke basement rock in the streams that cross-cut a Type A bulge just southwest of Featherston (Grapes \& Wellman, 1988). Waiohine gravels are also observed directly overlying greywacke basement rock in Waiohine River on the upthrown side of the fault, suggesting that Cenozoic sediments were either eroded or not originally deposited on the upthrown side of the Wairarapa Fault, perhaps due to a paleo-fault scarp. By measuring the angular unconformity between greywacke and Waiohine gravels at the above mentioned bulge, the degree of bulging that remained uneroded prior to Waiohine gravel deposition, might be inferred. Subsequent deposition of the Waiohine gravels completely covered the Type A faults and associated bulges in basement rock. The stratigraphic discontinuity that now exists between the base of the Waiohine gravels and the underlying basement rock, is inferred to have caused these Type A faults to branch outward at this discontinuity while propagating upward (relatively quickly) through the previously unfaulted Waiohine gravels to the surface as Type B faults (Figure 26). These Type B faults are arranged en echelon to the Type A fault segment that they branch from at the base of the gravels. Since the deposition of the Waiohine gravels, Type A bulges in the large stepovers between Type A fault segments have continued to develop, and Type B bulges have begun to form in the smaller stepover region between Type B segments (Figure 26).

The tectonic processes that have resulted in the branching of the young Wairarapa Fault into Type A fault segments at $\sim 200 \mathrm{~m}$ depth are unknown (sections 3.8.1 \& 3.8.2). We speculate that this Type A fault segmentation may have occurred in response topographically-induced changes in the near-surface stress field, or that the tip of the young Wairarapa Fault temporarily stalled at that depth, before it finally ruptured through to the surface. The influence of topography on near-surface fault geometry has typically not been considered in the majority of analogue models. Norris \& Cooper $(1995 ; 1997)$ describe the role of topography in producing segmentation along the transpressional Alpine Fault, New Zealand, using analogue models of an obliquely deforming wedge and field observations. The Alpine Fault exhibits what they describe as 'serial partitioning', where the fault trace is 
not straight on a scale of a few kilometres, but consists of oblique-thrust segments linked by dominantly strike-slip fault segments, that intersect where major river valleys cross the fault (Norris \& Cooper, 1995; 1997). The segmentation is considered characteristic of transpression, but the pattern is strongly influenced by erosion and topography (Norris \& Cooper, 1997). They attribute the segmentation to variations in the near surface stress field caused by the topographic relief at river valleys (Norris \& Cooper, 1995). The depth of the stress field disturbance is predicted to be a function of the wavelength and amplitude of the relief (Norris \& Cooper, 1995). The segmentation of the Alpine Fault extends to depths of 3-4 km, at which the oblique-slip and strike-slip segments are thought to merge into a single dipping fault plane (Norris \& Coopers, 1995).

\subsubsection{Asymmetry of deformational surface structures along the Wairarapa Fault}

The Wairarapa Fault is a northwest dipping dextral-oblique fault, not a vertically dipping pure strike-slip fault. This difference appears to control the asymmetry of the shapes of Type A and B pressure bulges, along and across fault strike, and the partitioned nature of oblique fault slip between different segments of the Wairarapa Fault. In plan view, Type A and Type B pressure bulges along the Wairarapa Fault typically exhibit an asymmetric triangular shape, with a sharp northeast-pointing tip, and a wide, rounded base to the southwest. In addition, discontinuous fault segments exhibit an across-strike asymmetry, with a greater proportion of their length developing above the downthrown side of the basement fault block than the upthrown side. Our observations indicate that the sense of vertical displacement switches where the fault segment crosses the basement fault.

The differential height of fault scarps suggest that the magnitude of dip-slip displacement is typically much greater on fault segments bounding the southeast sides of Type A and B bulges (in an up-to-the-northwest sense) than on faults bounding the northwest sides of the bulges (with an opposite up-to-the-southeast sense of displacement). In some cases the northwest bounding faults exhibit almost no dip-slip displacement (i.e. no topographic scarp is formed, e.g. Figure 24c). Dextral displacements of streams across both bounding faults were observed for at least two Type A bulges (Figures 22a \& h) and four Type B bulges (Figures 22b, j, k \& o) along the Wairarapa Fault. The streams at the southwest ends of these bulges clearly exhibit a larger component of strike-slip displacement on the northwest bounding faults, and little, or no strike-slip displacement on the southeast bounding faults. From these observations, we infer that the bulges southeast bounding faults on the downthrown side of the Wairarapa Fault zone dip more shallowly to accommodate a larger proportion of dip-slip displacement, whereas the northwest 
bounding faults on the upthrown side probably have sub-vertical dips and accommodate a larger component of strike-slip displacement.

The vertical and horizontal displacements quantified for the faults bounding two Type C bulges (section 3.7.1, Figures 22c \& d), do not reflect this partitioning of strike- and dipslip. At these Type $\mathrm{C}$ bulges, the northwest bounding faults accommodate the least strikeand dip-slip displacements, whereas the southeast bounding faults accommodate the greatest dip-slip displacement, and strike-slip displacements are distributed across the central or southeast bounding faults (Figures $22 \mathrm{c} \& \mathrm{~d}$ ). Type $\mathrm{C}$ bulges may not exhibit such clear slip-partitioning across their bounding faults because they are more evolved than the Type A and B bulges, where their bounding faults completely overlap to form enclosed shear lenses, within which there is much internal deformation. The formation of shear lenses may encourage the northwest bounding fault to shut off or at least accommodate less strike- and dip-slip displacement than during its earlier stages of development.

The partitioning of slip between faults in the stepover region, and the greater length of Rfaults above the downthrown fault block are predicted in analogue models of deformation above a basement reverse-oblique fault, for convergence angles at least as low as $\sim 7^{\circ}$ (e.g. Figure 10 of Richard et al., 1995). Partitioning of strike- and dip-slip displacements across adjacent faults branches has been reported at various scales for a number of natural transpressive settings (e.g. Eusden et al., 2000; Xu et al., 2009). Eusden et al., (2000) describe almost complete partitioning of slip across a transpressive duplex associated with a mild restraining bend in the Hope Fault. The propagation of reverse faults during the initiation of the duplex took place in the footwall, rather than symmetrically into both the hangingwall and footwall, as in classic restraining bends (Eusden et al., 2000). Evidence of oblique strike-slip is clearly observed on the hanging-wall of the main fault, while only dipslip faults are observed in the footwall duplex (Eusden et al., 2000). The asymmetry is attributed by these authors to the steep dip of the main fault, and its oblique slip-vector, and may be aided by a rheological contrast between more competent uplifted basement rocks in the hangingwall, against the weaker sedimentary succession in the footwall, which would favour fault propagation into the structurally higher levels of the footwall (Eusden et al., 2000). Oblique slip at depth is partitioned across two fault branches in the near-surface along the Longmenshan thrust belt, at the eastern margin of the Tibetan Plateau (e.g. Xu et al., 2009). Here, the shallowly-dipping Pengguan thrust fault exhibits a greater component of reverse displacement than the more steeply-dipping reverse-oblique Beichuan Fault. The 
faults converge into a single oblique-reverse fault plane at a depth of 5-10 km (Xu et al., 2009).

\subsection{Conclusions}

Detailed analyses of surface faults and deformational pressure bulges along the central section of the Wairarapa Fault, including volume calculations at two bulges and comparisons with scaled analogue models, provide new insights into the 3D geometry of faults, and development of fault segmentation and pressure bulges along this active strikeslip fault. Our findings are summarised by the following conclusions.

(1) The Wairarapa Fault appears to be a young splay that has propagated upward through previously unfaulted material from an older Wairarapa Fault at depth closer to the Rimutaka Ranges. The formation of this relatively immature, currently active Wairarapa Fault plane well to the east of the ranges reflects the propagation of deformation eastwards into the Wairarapa Valley, in response to topographic loading of the ranges. The young Wairarapa Fault exhibits the surface deformation characteristics of a strike-slip fault that is in an early stage of its evolution. From scaled analogue models, we qualitatively estimate a finite dextral displacement on the young fault plane within basement of between $\sim 130 \mathrm{~m}$ and $\sim 1700 \mathrm{~m}$. The maximum finite displacement estimate, together with new Late Quaternary dextral slip rate estimates on the Wairarapa Fault, suggests that this young fault branch has propagated eastwards to the surface some time after 100-250 ka in the Late Pleistocene.

(2) The convergence depths of Type A and Type B fault segments define a hierarchy of en echelon structures. The convergence depths of splays bounding Type A pressure bulges are estimated as $\sim 100-260 \mathrm{~m}$, suggesting that Type A en echelon fault segments separated by the largest fault stepover widths (250-350 m), converge into a single basement fault well below the LGM Waiohine gravels, within basement rock. We infer that an en echelon array of $\mathrm{R}$-faults separated by large stepovers existed in the basement rock prior to deposition of the Waiohine gravels, and that the early development of Type A bulges thus probably occurred in these stepover regions also prior to gravel deposition. The convergence depths for splays bounding Type B bulges are estimated as $\sim 1-18 \mathrm{~m}$, suggesting that Type B en echelon 
fault segments separated by smaller fault stepover widths (30-150 m), converge into Type A fault segments at or near the base of the Waiohine gravels. Type B faults therefore represent an accumulation of distributed deformation in the previously unfaulted Waiohine gravels since their rapid deposition above pre-existing faults in basement. The least common Type $C$ bulges appear to have formed along parts of the fault where the stage of fault evolution is locally higher, and through-going faults have dissected these bulges, decreasing their amplitude.

The boundary conditions at the Wairarapa Fault are most comparable to analogue models of the deformation of a previously unfaulted, non-cohesive overburden above a dipping single strike-slip to slightly oblique-slip basement fault. The surface pattern of faults at the Wairarapa Fault is similar to that predicted by these models. Important differences, however, are that in the natural case of the Wairarapa Fault, the discontinuous Type A and B fault segments strike at an angle of $2^{\circ}-18^{\circ}$ (average of $\sim 6-7^{\circ}$ ) to the average strike of the higher-order fault segment to which they belong (rather than $\sim 10-30^{\circ}$ as predicted by the analogue models), and the Wairarapa Fault zone is $\sim 350 \mathrm{~m}$ wide (rather than $1-2 \mathrm{~km}$ as predicted by these models). We interpret these differences in fault strike angle chiefly to reflect the shallow fault convergence depths (for reasons uncertain) at the Wairarapa Fault in comparison to those implied by the thickly sedimented analogue models.

(3) The asymmetry of surface structures along the Wairarapa Fault reflects the obliquity of convergence at the fault zone and the northwest dip of the fault plane at depth. The Type A and Type B pressure bulges are asymmetric in shape, with a pointy tip to the northeast and a rounded base to the southwest. The en echelon fault segments exhibit an across-strike asymmetry, with a greater percentage of their length above the downthrown side of the basement fault block than the upthrown side. Type A and B pressure bulges display an asymmetric partitioning of slip across faults in the stepover area. Faults bounding the northwest sides of the bulges accommodate a greater component of horizontal displacement, and are inferred to have a steep or sub-vertical dip, while faults bounding the southeast sides of the bulges accommodate a greater component of vertical displacement, and are inferred to dip more shallowly to the northwest. 


\section{Conclusions}

This study of the tectonic geomorphology and paleoseismology of the central part of the Wairarapa Fault yields new insights into the styles and rates of Late Quaternary deformation along this active oblique strike-slip fault. The major conclusions of this study are summarised below.

From our detailed investigation of the interaction between the active Wairarapa Fault and the flight of variably displaced degradation terraces incised into the Waiohine aggradation surface at Waiohine River, we conclude that a model of complete riser trimming is most appropriate for these terraces. This conclusion is based on the similar lateral offsets of paleochannels incised into the terrace surfaces, and adjacent riser displacements. Each riser began recording lateral displacement only after its lower bounding terrace tread had been abandoned. This knowledge is a necessary prerequisite to the assigning of ages to the measured terrace riser displacements. Although a complete riser trimming model is appropriate for the Waiohine terraces, this may not be the case for other displaced terrace sequences. A careful comparison between riser and paleochannel displacements is necessary in each case to determine the most appropriate riser trimming model. We note that a comparison between riser displacements and the difference in terrace widths across the fault, alone is insufficient to distinguish between the different riser trimming models.

We mapped the variably displaced Waiohine terraces in detail using RTK GPS and EDM techniques. Digital Elevation Models (DEM) produced from these data, together with high-resolution aerial photography, allowed us to measure the displacements of 6 terrace surfaces, 5 risers and 2 paleo-channels. The cumulative strike-slip displacements range from $12.4 \pm 0.8 \mathrm{~m}(2 \sigma)$ to $101.1 \pm 3.4 \mathrm{~m}(2 \sigma)$, and the cumulative vertical displacements range from $1.3 \pm 0.02 \mathrm{~m}(2 \sigma)$ to $19.7 \pm 0.09 \mathrm{~m}(2 \sigma)$. The ratio of horizontal to vertical slip for the Waiohine terraces ranges from 5.0 to 10.2 , with an average of $6.9 \pm 3.5(2 \sigma)$. Terrace age data were obtained by Optically Stimulated Luminescence (OSL) dating of terrace sands and silts at the Waiohine terraces. The Late Quaternary dextral slip rate for the central part of the Wairarapa Fault is estimated from two terrace-riser pairs. Based on previously published OSL age data, and our new estimated displacement of the 'Waiohine' aggradation surface, we calculate a dextral slip rate of $12.0 \pm 3.5 \mathrm{~mm} / \mathrm{yr}(1 \sigma)$. Using the dextral displacement and maximum OSL age determined in this study for the next younger terrace, we find a minimum dextral slip rate of $7.2 \pm 0.8 \mathrm{~mm} / \mathrm{yr}(1 \sigma)$. The magnitudes of 
the inferred 1855 (smallest displacement) and penultimate (next-smallest displacement) single-event displacements are $12.4 \pm 0.8 \mathrm{~m}(2 \sigma)$ and $9.7 \pm 1.7 \mathrm{~m}(2 \sigma)$, respectively, implying a mean co-seismic dextral displacement of $10.6 \pm 2.6 \mathrm{~m}(2 \sigma)$ at the Waiohine terraces for the last two earthquakes on the Wairarapa Fault. These new estimates of Late Quaternary slip rate and single-event displacements on the Wairarapa Fault are important data that will be relevant for any future seismic hazard assessments. The uncertainty in the Late Quaternary dextral slip rate estimate may be reduced by better terrace age analysis, which should be a topic of further investigation.

Late Quaternary dextral slip rate of the Wairarapa Fault appears to decrease northward, although this is difficult to quantify. Similarly, the single-event (co-seismic) dextral displacements inferred for the 1855 and penultimate earthquakes on the Wairarapa Fault also appear to decrease northward. Between the southern section of the Wairarapa Fault near Pigeon Bush and the central section near Waiohine River (along-strike distance of 15$20 \mathrm{~km}$ ), a 10-30\% decrease in 1855 and penultimate single-event displacements is evident. Inferred 1855 earthquake co-seismic dextral displacements decrease by 10-50\% from the central section of the fault near Waiohine River to the northern section near Mauriceville (along-strike distance of $\sim 35 \mathrm{~km}$ ). We suggest that a similarity of this type of along-strike reduction in coseismic slip during repeated earthquakes may be responsible for the apparent northward decrease in the Late Quaternary dextral slip rate along the fault. Presumably, the missing dextral slip on the northern part of the fault has been shunted off onto one or a combination of the Carterton, Masterton and Mokonui Faults during Wairarapa Fault earthquakes. It is vital to quantitatively assess these along-strike variations in slip rate and co-seismic slip in order to assess how earthquake ruptures propagate along the Wairarapa Fault for earthquake hazard evaluation, and to determine the involvement of the Carterton, Masterton and Mokonui Faults during Wairarapa Fault earthquakes.

The near-surface 3D geometry of the Wairarapa Fault is characterised by a hierarchy of en echelon fault segments including adjacent and overlapping splays that dip towards one another, with deformational bulges in the fault stepover regions. Through volume calculations at two pressure bulges along the Wairarapa Fault, we gain insight into the depth extent of these surface deformational structures. The calculated convergence depths for the larger examples of these discontinuous fault segments, separated by the largest fault stepover widths (250-350 m) and bounding the largest pressure bulges, are $\sim 100-260 \mathrm{~m}$, suggesting that these larger (Type A) fault segments converge into a deeper master fault plane within basement rock, and well below the base of the post-LGM Waiohine gravels. 
This result implies that an en echelon array of discontinuous fault segments separated by large stepovers existed in the basement rock prior to deposition of the Waiohine gravels, and that the early development of the larger (Type A) bulges thus probably occurred in these stepover regions also prior to gravel deposition.

A set of much smaller fault segments that have stepover widths of $30-150 \mathrm{~m}$ and that bound smaller pressure bulges, have calculated convergence depths of $\sim 1-18 \mathrm{~m}$, suggesting that these smaller (Type B) fault segments converge downward into a single fault plane at or near the base of the Waiohine gravels. These Type B faults therefore probably represent distributed deformation in the previously unfaulted Waiohine gravels that has been localised above the pre-existing fault in basement, and that has only occurred since the deposition of the Waiohine gravels before $\sim 12 \mathrm{ka}$. The sliver-like, very elongate, least common style of bulges, appear to have formed along "hard-linked" parts of the fault zone where the stage of fault evolution is locally higher. The relatively shallow extent of near surface fault segmentation along the Wairarapa Fault suggests that even the largest Type A fault stepovers probably do not act as barriers to earthquake rupture propagation along the fault (as is evident from the onshore rupture distance of $>120 \mathrm{~km}$ in the 1855 Wairarapa Fault earthquake).

We infer that the Wairarapa Fault is a young splay that has propagated upward through previously unfaulted material from an older Wairarapa Fault at depth, closer to the Rimutaka Ranges. The formation of this relatively immature, currently active, northwestdipping Wairarapa Fault plane $\sim 100-400 \mathrm{~m}$ east of the topographically expressed range front, may reflect propagation of an eastward splay of the fault into the Wairarapa Valley in response to topographic loading of the ranges to the west. The young Wairarapa Fault exhibits the surface deformation characteristics of an oblique strike-slip fault that is only in the early stage of its evolution, an apparent immaturity that is not simply restricted to the deformation of the surficial Waiohine gravels. By reference to the results of previously published analogue models and up-scaling of these results to the natural setting, we qualitatively estimate a finite dextral displacement on the currently active strand of the Wairarapa Fault of between $\sim 130 \mathrm{~m}$ and $\sim 1700 \mathrm{~m}$. Together with our new Late Quaternary dextral slip rate estimate for the Wairarapa Fault of $12.0 \pm 3.5 \mathrm{~mm} / \mathrm{yr}$, the maximum finite displacement estimate implies an age of inception for this young fault branch of 100-250 ka or younger. 
Our observations of surface deformation along the Wairarapa Fault differ to the predictions of analogue models of the deformation of a previously unfaulted, non-cohesive overburden above a vertical strike-slip to slightly oblique-slip and dipping basement fault, in two ways. The larger and smaller sets of discontinuous fault ( $\mathrm{R}$-fault) segments (Types A and B) both strike at an angle of only $2^{\circ}-18^{\circ}$ (average of $\sim 6-7^{\circ}$ ) clockwise of the mean strike of the fault that contains them. By comparison, R-faults forming in these analogue models generally strike at an angle of $10^{\circ}-30^{\circ}$ to the strike of the basement fault. The Wairarapa Fault zone is only $\sim 350 \mathrm{~m}$ wide, whereas, the scaled-up fault zone widths implied by these analogue models are $1-2 \mathrm{~km}$. The differences in strike angle and fault zone width between nature and the analogue models are attributed to the shallow fault convergence depths at the Wairarapa Fault in comparison to those created by the deep layer of surficial "overburden" in the analogue models.

The obliquity of convergence at the Wairarapa Fault zone and the northwest dip of the fault plane at depth cause an asymmetry of the surface structures along the Wairarapa Fault. This asymmetry is reflected by the asymmetry and triangular shape of Type A and B pressure bulges in plan view, the across-strike asymmetry of the faults and bulges in profile, and also by partitioning of oblique slip components between the two different splays bounding a given pressure bulge along the Wairarapa Fault. Our study at the Wairarapa Fault provides a general understanding of the development of faults and deformational structures along reverse-oblique strike-slip faults; however, further fault evolution analogue modelling experimenting with different fault dips and convergence angles would be beneficial to further our understanding these structures. Such models might investigate the formation of asymmetric deformational surface structures in obliquely convergent settings. 


\section{References}

Arrowsmith, J. R., and Rhodes, D. D. 1994. Original Forms and Initial Modofications of the Galway Lake Road Scarp Formed along the Emerson Fault during the 28 June 1992 Landers, California, Earthquake: Bulletin of the Seismological Scoeity of America, v. 84, no. 3, p. 511-527.

Adamiec, G. and Aitken, M. J. 1998. Dose-rate conversion factors: update. Ancient TL, v. 16 , p. $37-50$.

Armijo, R., Tapponnier, P., and Tonglin, H. 1989. Late Cenozoic Right-Lateral Strike-Slip Faulting in Southern Tibet: Journal of Geophysical Research, v. 94, no. B3, p. 27872838.

Avouac, J. 1993. Analysis of Scarp Profiles: Evaluation of Errors in Morphologic Dating: Journal of Geophysical Research, v. 98, no. B4, p. 6745-6754.

Aydin A. A., and Nur, A. 1985. The types and roles of stepovers in strike-slip tectonics. From: Biddle, K. T., and Christie-Blick, N. (eds) Strike-slip deformation, basin formation, and sedimentation: SEPM Special Publication, v. 37, p. 35-45.

Barnes, P. M. 2005. The southern end of the Wairarapa Fault, and surrounding structures in Cook Strait, in Proceedings Volume: The 1855 Wairarapa Fault Symposium, Museum of New Zealand, Te Papa Tongarewa.

Barnes, P. M., and Audru, J.-C. 1999. Quaternary faulting in the offshore Flaxbourne and Wairarapa Basins, southern Cook Strait, New Zealand: New Zealand Journal of Geology and Geophysics, v. 42, p. 349-367.

Barnes, P. M., and Mercier de Lepinay, B. 1997. Rates and mechanics of rapid frontal accretion along the very obliquely convergent southern Hikurangi margin, New Zealand: Journal of Geophysical Research, v. 102, No. B11, p. 24,931-24,952.

Barnes, P. M., Mercier de Lepinay, B., Collot, J.-Y., Delteil, J., and Audru, J.-C. 1998. Strain partitioning in the transition area between oblique subduction and continental collision, Hikurangi margin, New Zealand: Tectonics, v. 17, p. 534-557.

Beanland, S. 1995. The North Island Dextral Fault Belt [Ph. D. thesis]: Victoria University of Wellington, $341 \mathrm{p}$.

Beanland, S., and Haines, J. 1998. A kinematic model of active deformation in the North Island, New Zealand, determined from geological strain rates: New Zealand Journal of Geology and Geophysics, v. 41, p. 311-324.

Beavan, J., Tregoning, P., Bevis, M., Kato, T., and Meertens, C. 2002. Motion and rigidity of the Pacific Plate and implications for plate boundary deformation: Journal of Geophysical Research, v. 107, no: B10, p. 2261.

Begg, J.G., and Johnston, M.R. 2000. Geology of the Wellington Area, New Zealand (Geological Map and Accompanying Booklet): Institute of Geological and Nuclear Sciences. Geological Map 10, scale 1:250,000.

Begg, J.G. \& Mazengarb, C. 1996. Geology of the Wellington Area, New Zealand 9Geological Map and accompanying Booklet): Institute of Geological \& Nuclear Sciences. Geological Map 22, scale 1:50,000.

Bergerat, F., Angelier, J., Gudmundsson, A., and Torfason, H. 2003. Push-ups, fracture patterns, and paleoseismology of the Leirubakki Fault, South Iceland: Journal of Structural geology, v. 25, p. 591-609.

Berryman, K. 1990. Late Quaternary movement on the Wellington Fault in the Upper Hutt area, New Zealand: New Zealand Journal of Geology and Geophysics, v. 33, p. 257-270.

Browne, G. H. 1992. The northeastern portion of the Clarence Fault: tectonic implicationd for the late Neogene evolution of Marlborough, New Zealand: New Zealand Journal of Geology and Geophysics, v. 35, p. 437-445.

Casas, A. M., Gapais, D., Nalpas, T., Besnard, K., and Roman-Berdiel, T. 2001. Analogue models of transpressive systems: Journal of Structural Geology, v. 23, p. 733-743. 
Cloos, H. 1928. Experimente zur inneren Tektonic: Centralblatt fur Mineralogie, 1928B, p. 609-621.

Cowgill, E. 2007. Impact of riser reconstructions on estimation of secular variation in rates of strike-slip faulting: Revisiting the Cherchen River site along the Altyn Tagh Fault, NW China: Earth \& Planetary Science Letters, v. 254, p. 239-255.

Cowgill, E., Arrowsmith, J. R., Yin, A., Xiaofeng, W., and Zhengle, C. 2004. The Akato Tagh bend along the Altyn tagh Fault, northwest Tibet, 2: active deformation and the importance of transpression and strain hardening within the Altyn Tagh system: Geological Society of America bulletin, v. 116, p. 1443-1464.

Cunningham, W. D., and Mann, P. 2007. Tectonics of strike-slip restraining and releasing bends. From: Cunningham, W. D., and Mann, P. (eds) Tectonics of Strike-Slip Restraining and Releasing Bends. Geological Society, London, Special Publications, v. 290, p. 1-12.

Darby, D. J., and Beavan, J., 2001, Evidence from GPS measurements for contemporary interplate coupling on the Southern Hikurangi subduction thrust and for partitioning of strain into the upper plate: Journal of Geophysical Research, v. 106(B12), p. 30881-30891.

DeMets, C., Gordon, R. G., Argus, D. F., and Stein, S. 1990. Current plate motions: Geophysical Journal International, v. 101, p. 425-478.

DeMets, C., Gordon, R. G., Argus, D. F., and Stein, S. 1994. Effect of recent revisions to the geomagnetic reversal time scale on estimates of current plate motions: Geophysical Research Letters, v. 21, p. 2191-2194.

Duller, G.A.T. 1994. Luminescence dating of poorly bleached sediments from Scotland. Quaternary Science Reviews, v. 13, p. 521-524.

Duller, G.A.T., Wintle, A.G. and Hall, A.M. 1995. Luminescence dating and its application to key pre-late Devensian sites in Scotland. Quarternay Science Reviews, v. 14, p. 495-519.

Emmons, R. C. 1969. Strike-slip rupture patterns in sand models: Tectonophysics, v. 7, p. 71-87.

Eusden, J. D., Pettinga, J. R., and Campbell, J. K. 2000. Structural evolution and landscape development of a transpressive duplex on the Hope Fault, North Canterbury, New Zealand: New Zealand Journal of Geology and Geophysics, v. 43, p. 391-404.

Formento-Trigilio, M. L., Burbank, D. W., Nicol, A., Shulmeister, J., and Rierser, U. 2002. River response to an active fold-and-thrust belt in a convergent margin setting, North Island, New Zealand: geomorphology, v. 49, p. 125-152.

Gamond, J. F. 1987. Bridge structures as sense of displacement criteria in brittle fault zones: Journal of Structural Geology, v. 9, p. 609-620.

Grapes, R. H. 1991. Aggradation surfaces and implications for displacement rates along the Wairarapa Fault, southern North Island, New Zealand: Catena, v. 18, p. 453-469.

Grapes, R. H. 1999. Geomorphology of faulting: the Wairarapa Fault, New Zealand: Zeitschrift fur Geomorphologie, v. 115, p. 191-217.

Grapes, R. H., and Wellman, H. W. 1988. The Wairarapa Fault: Victoria University of Wellington Geology Board of Studies, v. 4, p. 54.

Graymer, R. W., Langenheim, V. E., Simpson, R. W., Jachens, R. C., and Ponce, D. A. 2007. Relatively simple through-going fault planes at large-earthquake depth may be concealed by the surface complexity of strike-slip faults. From: Cunningham, W. D., and Mann, P. (eds) Tectonics of Strike-Slip Restraining and Releasing Bends. Geological Society, London, Special Publications, v. 290, p. 169-188.

Groshong, R. H. Jr. 1994. Area balance, depth to detachment, and strain in extension: Tectonics, v. 13, no. 6, p. 1488-1497

Harkins, N., and Kirby, E. 2008. Fluvial terrace riser degradation and determination of slip rates on strike-slip faults: An example from the Kunlun fault, China: Geophysical Research Letters, v. 35, L05406, doi: 10.1029/2007GL033073. 
Hempton, M. R., and Neher, K. 1986. Experimental fracture, strain and subsidence patterns over en echelon strike-slip faults: implications for the structural evolution of pull-apart basins. Journal of Structural Geology, v. 8, no. 6, p. 597-605.

Hicks, S. R., and Woodward, D. J. 1978. Gravity models of the Wairarapa region, New Zealand: New Zealand Journal of Geology and Geophysics, v. 21, n. 5, p. 539-544.

Horsfield, W. T. 1977. An experimental approach to basement controlled faulting. From: Frost, R. T. C., and Dikkers, A. J. (eds) Fault Tectonics in NW Europe. Geologie mijnb, v. 56, p. 363-370.

Hubbert, M. K. 1937. Theory of scale models as applied to the study of geological structures: Bulletin of the Geological Society of America, v. 48. p. 1459-1520.

Hubbert, M. K. 1951. Mechanical basis for certain familiar geological structures: Bulletin of the Geological Society of America, v. 62, p. 355-372.

Hubert-Ferrari, A., Armijo, R., King, G., Meyer, B., and Barka, A. 2002. Morphology, displacement, and slip rates along the North Anatolian Fault, Turkey: Journal of Geophysical Research, v. 107, no. B10, 2235, doi: 10.1029/2001JB000393.

Jamison, W. R. 1991. Kinematics of compressional fold development in convergent wrench terranes: tectonophysics, v. 190, p. 209-232.

Kelsey, K. M., Cashman, S. M., Beanland, S., and Berryman, K. R. 1995. Structural evolution along the inner forearc of the obliquely convergent Hikurangi margin, New Zealand: Tectonics, v. 14, p. 1-18.

Lang, A., and Wagner, G. A. 1997. Infrared stimulated luminescence dating of Holocene colluvial sediments using the $410 \mathrm{~nm}$ emission. Quaternary Geochronology (Quaternary Science Reviews), v. 16, p. 393-396.

Lang, A., and Wagner, G. A. 1996. Infrared stimulated luminescence dating of archaeosediments. Archaeometry, v. 38, p. 129-141.

Langridge, R. M., and Berryman, K. R. 2005. Morphology and slip rate of the Hurunui section of the Hope Fault, South Island, New Zealand: New Zealand Journal of Geology and Geophysics, v. 48, p. 43-57.

Langridge, R. M., Berryman, K. R., and Van Dissen, R. J. 2005. Defining the geometric segmentation and Holocene slip rate of the Wellington Fault, New Zealand: the Pahiatua section: New Zealand Journal of Geology and Geophysics, v. 48, p. 591 607.

Langridge, R. M., Campbell, J., Hill, N., Pere, V., Pope, J., Pettinga, J., Estrada, B., and Berryman, K. 2003. Paleoseismology and slip rate of the Conway Segment of the Hope Fault at Greenburn Stream, South Island, New Zealand; Annals of Geophysics, v. 46, no. 5, p. 1119-1139.Lensen, G. J., and Vella, P. 1971. The Waiohine River Faulted Terrace Sequence in Recent Crustal Movements: Royal Society of New Zealand Bulletin, v. 9, p. 117-119.

Langridge, R. M., Van Dissen, R, J., Cochran, U. A., Litchfield, N. J., Berryman, K. R., Begg, J. G., Villamor, P., Heron, D., Nicol, A., and Townsend, D. 2005. Active faulting and paleoearthquakes in the Wairarapa and Wellington regions: In Proceedings of The 1855 Wairarapa Earthquake Symposium, September 2005, Published by Greater Wellington Regional Council: 66-71.

Lensen, G. J. 1964. The general case of progressive fault displacement of flights of degradational terraces: New Zealand Journal of Geology and Geophysics, v. 7, p. 864-870.

Lensen, G. J., and Vella, P. 1971. The Waiohine River Faulted Terrace Sequence in Recent Crustal Movements: Royal Society of New Zealand Bulletin, v. 9, p. 117-119.

Lin, A., Gue, J., and Fu, B. 2004. Co-seismic mole track structures produced by the 2001 Ms 8.1 Central Kunlun earthquake, China: Journal of Structural Geology, v. 26, p. 1511-1519. 
Litchfield, N., and Berryman, K. R. 2005. Correlation of fluvial terraces within the Hikurangi Margin, New Zealand: Implications for climate and base level controls: Geomorphology, v. 68, p. 291-313.

Litchfield, N., and Berryman, K. 2006. Relations between postglacial fluvial incision rates and uplift rates in the North Island, New Zealand: Journal of Geophysical Research, v. 111 FO2007, doi: 10.1029/2005JF000374.

Little, T. A., Grapes, R., and Berger, G. W. 1998. Late Quaternary strike slip on the eastern part of the Awatere fault, South Island, New Zealand: Geological Society of America Bulletin, v. 110, no. 2, p. 127-148.

Little, T. A., Van Dissen, R., Schermer, E., and Carne, R. 2009. Late Holocene surface ruptures on the southern Wairarapa Fault, New Zealand: Link between obliquereverse earthquakes and the raising of beach ridges on a rocky coast: Lithosphere, v. 1, no. 1, p. 4-28.

McClay, K., and Bonora, M. 2001. Analog models of restraining stepovers in strike-slip fault systems. American Association of Petroleum Geologists Bulletin, v. 85, no. 2, p. 233-260.

Malverti, L., Lajeunesse, E., and Metivier, F. 2007. Experimental investigation of the response of an alluvial river to a vertical offset of its bed. In Dohmen Janssen and Hulscher (eds): River, Coastal and Estuarine Morphodynamics: London, Taylor \& Francis Group, p. 179-184

Mandl, G., De Jong, L. N. J., and Maltha, A. 1977. Shear zones in granular materical: Rock Mechanics, v.9, p. 95-144.

Mann, P. 2007. Global catalogue, classification and tectonic origins of restraining- and releasing bends on active and ancient strike-slip fault systems. From: Cunningham, W. D., and Mann, P. (eds) Tectonics of Strike-Slip Restraining and Releasing Bends. Geological Society, London, Special Publications, v. 290, p. 13-142.

Mason, D. P. M., Little, T. A., and Van Dissen, R. J. 2006. Rates of active faulting during late Quaternary fluvial terrace formation at Saxton River, Awatere Fault, New Zealand: Geological Society of America Bulletin, v. 118, no. 11/12, p. 1,431-1,446.

Meriaux, A. -S., Ryerson, F. J., Tapponnier, P., Van der Woerd, J., Finkel, R. C., Xiwei, X., Zhiqin, X., and Caffee, M. W. 2004. Rapid slip along the central Altyn Tagh Fault: Morphochronologic evidence from Cherchen He and Sulamu Tagh: Journal of Geophysical Research, v. 109, B06401, doi: 10.1029/2003JB002558.

Meriaux, A. -S., Tapponnier, P., Ryerson, F. J., Xiwei, X., King, G., Van der Woerd, J., Finkel, R. C., Haibing, L., Caffee, M. W., Zhiqin, X., and Wenbin, C. 2005. The Aksay segment of the northern Altyn Tagh Fault: tectonic geomorphology, landscape evolution, and Holocene slip rate: Journal of Geophysical Research, v. 110, B04404, doi: 10.1029/2004JB003210.

Milne, J.D. 1973. Upper Quaternary geology of the Rangitikei drainage basin. PhD Dissertation, Victoria University of Wellington, New Zealand.

Naylor, M. A., Mandl, G., and Sijpesteijn, C. H. K. 1986. Fault geometries in basementinduced wrench faulting under different initial stress states. Journal of Structural Geology, v. 8, no. 7, p. 737-752.

Nicol, A., Mazengarb, C., Chanier, F., Rait, G., Uruski, C., and Wallace, L. 2007. Tectonic evolution of the active Hikurangi subduction margin, New Zealand, since the Oligocene: Tectonics, v. 2, p. TC4002, doi: 10.1029/2006TC002090.

Nicol, A., and Van Dissen, R. 2002. Up-dip partitioning of displacement components on the oblique-slip Clarence Fault, New Zealand: Journal of Structural Geology, v. 24, p. 1521-1535.

Nicol, A., Van Dissen, R., Vella, P., Alloway, B., and Melhuish, A. 2002. Growth of contractional structures during the last 10 m.y. at the southern end of the emergent Hikurangi forearc basin, New Zealand: New Zealand Journal of Geology and Geophysics, v. 45 p. 365-385. 
Norris, R. J., and Cooper, A. F. 1995. Origin of small-scale segmentation and transpressional thrusting along the Alpine Fault, New Zealand: Geological Society of America Bulletin, v. 107, no. 2, p. 231-240.

Norris, R. J., and Cooper, A. F. 1997. Erosional control on the structural evolution of a transpressional thrust complex on the Alpine Fault, New Zealand: Journal of Structural Geology, v. 19, no. 10, p. 1323-1342.

Odonne, F., and Vialon, P. 1983. Analogue Models of Folds above a Wrench Fault: Tectonophysics, v. 99, p. 31-46.

Olley, J.M., Caitcheon, G., and Murray, A.S. 1998. Variations in the apparent dose of different size fractions of fluvial quartz: implications for dating of young sediments. Quaternary Science Reviews (Quaternary Geochronology), v. 17, p. 1033-1040.

Olley, J.M., Caitcheon, G.G., and Roberts, R.G. 1999. The origin of dose distributions in fluvial sediments, and the prospect of dating single grains from fluvial deposits using optically stimulated luminescence. Radiation Measurements, V. 30, p. 207217.

Reyners, M. 1998. Plate coupling and the hazard of large subduction thrust earthquakes at the Hikurangi subduction zone, New Zealand: New Zealand Journal of Geology and Geophysics, v. 41, p. 343-354.

Richard, P. 1991. Experiments on faulting in a two-layer cover sequence overlying a reactivated basement fault with oblique-slip. Journal of Structural Geology, v. 13, no. 4, p. 459-469.

Richard, P. D., Naylor, M. A., and Koopman, A. 1995. Experimental models of strike-slip tectonics. Petroleum Geoscience, v. 1, p. 71-80.

Riedel, W. 1929. Zur mechanik geologischer brucherscheinungen: Centralblatt fur Minerologie, Geologie und Paleontologie, 1929B, p. 354.

Rodgers, D. W., and Little, T. A. 2006. World's largest co-seismic strike-slip offset: The 1855 rupture of the Wairarapa Fault, New Zealand, and implications for displacement/length scaling of continental earthquakes: Journal of Geophysical Research, v. 111, p. B12408, doi:10.1029/2005JB004065.

Rowen, C. J., and Roberts, A. P. 2008. Widespread remagnetizations and a new view of Neogene tectonic rotations within the Australia-Pacific plate boundary zone, New Zealand: Journal of Geophysical Research, v. 113, doi: 10.1029/2006JB004594

Sanderson, D. J., and Marchini, W. R. D. 1984. Transpression: Journal of Structural Geology, v. 6, p. 449-458.

Schermer, E. R., Little, T. A., and Rieser, U. (in review). Quaternary deformation along the Wharekauhau fault system, North Island, New Zealand: implications for an unstable linkage between active strike-slip and thrust faults: Tectonics.

Schermer, E. R., Van Dissen, R., Berryman, K. R., Kelsey, H. M., and Cashman, S. M. 2004. Active faults, paleoseismology, and historical fault rupture in northern Wairarapa, North Island: New Zealand Journal of Geology and Geophysics, v. 47, p. 107-122.

Schreurs, G. 2003. Fault development and interaction in distributed strike-slip shear zones: an experimental approach. From: Storti, F., Holdsworth, R. E., and Salvini, F. (eds) Intraplate Strike-Slip Deofrmation Belts. Geological Society, London, Special Publications, v. 210, p. 35-52.

Schreurs, G., and Colletta, B. 1998. Analogue modelling of faulting in zones of continental transpression and transtension. From: Holdsworth, R. E., Strachan, R. A., and Dewey, J. F. (eds) Continental Transpressional and Transtensional Tectonics. Geological Society, London, Special Publications, v. 135, p. 59-79.

Sieh, K. 1984. Lateral offsets and revised dates of large earthquakes at Pallett Creek, California: Journal of Geophysical Research, v. 89, p. 7641-7670. 
Singhvi, A.K. and Lang, A. 1998. Improvements in infra-red stimulated dating of partially bleached sediments - the 'differential' bleach technique. Ancient TL, v.16, p. 6371.

Suggate, R. P. 1960. The interpretation of progressive fault displacement of flights of terraces: New Zealand Journal of Geology and Geophysics, v. 3, p. 364-374.

Swanson, M. T. 1989. Sidewall ripouts in strike-slip faults: Journal of Structural Geology, v. 11, p. 933-948.

Sylvester, A. G. 1988. Strike-slip faults: Geological Society of America Bulletin, v. 100, p. 1666-1703.

Tchalenko, J. S. 1968. The evolution of kink-bands and the development of compressional textures in sheared clay: Tectonophysics, v. 6, p. 159-174.

Tchalenko, J. S. 1970. Similarities between Shear Zones of Different Magnitudes. Geological Society of America Bulletin, v. 81, p. 1625-1640.

Tchalenko, J. S., and Ambraseys, N. N. 1970. Structural Analysis of the Dashat-e Bayaz (Iran) earthquake fractures: Geological Society of America Bulletin, v. 81, p. 41-60.

Ueta, K., Tani, K., and Kato, T. 2000. Computerized X-ray tomography analysis of threedimensional fault geometries in basement-induced wrench faulting: Engineering Geology, v. 56, p. 197-210.

Van der Woerd, J., Tapponier, P., Ryerson, F. J., Meriaux, A. S., Meyer, B., Gaudemer, Y., Finkel, R. C., , Caffee, M. W., Zhao, G., and Xu, Z. 2002. Uniform postglacial sliprate along the central $600 \mathrm{~km}$ of the Kunlun Fault (Tibet), from ${ }^{26} \mathrm{Al},{ }^{10} \mathrm{Be}$, and ${ }^{14} \mathrm{C}$ dating of riser offsets, and climatic origin of the regional morphology: Geophysical Journal International, v. 148, p. 356-388.

Van Dissen, R. J., and Berryman, K. R. 1996. Surface rupture earthquakes over the last $\sim 100$ years in the Wellington region, New Zealand, and implications for ground shaking hazard: Journal of Geophysical Research, v. 101, p. 5999-6019.

Van Dissen, R. J., Berryman, K., Pettinga, J. R., and Hill, N. L. 1992. Paleoseismicity of the Wellington-Hutt Valley Segment of the Wellington Fault, North Island, New Zealand: New Zealand Journal of Geology and Geophysics, v. 35, p. 165-176.

Van Dissen, R. J., Little, T. A., and Nicol, A. 2005. Faults of Eastern Marlborough: Picton, Awatere and Kekerengu. In: Pettinga, J. R. and Wandres, A. M. (eds.) Field Trip Guides, Geological Society of New Zealand $50^{\text {th }}$ Annual Conference, Kaikoura, New Zealand. Geological Society of New Zealand Misc. Publ. 119B, p. 85-110.

Villamor, P., Langridge, R. M., Ries, W., Carne, R., Wilson, K., Seebeck, H., and Cowan, L. 2008. It's Our Fault - Wairarapa Fault Slip Rate Investigations Task: Completion Report - Is the Wairarapa Fault slip rate decreasing to the north? GNS Consultancy Report 2008/170. 58p.

Von Borstel, O. I., and Ingham, M. 2004. Imaging the Wairarapa Fault at Tauwharenikau using magnetotelluric sounding: New Zealand Journal of geology and Geophysics, v. 47 , p. $281-286$.

Wallace, L., Beavan, J., McCaffrey, R., and Darby, D., 2004, Subduction zone coupling and tectonic block rotation in the North Island, New Zealand: Journal of Geophysical Research, v. 109 (no. B12), p. doi: 10.1029/2004JB003241.

Wallace, L. M., Reyners, M., Cochran, U., Banister, S., Barnes, P., Berryman, K., Downes, G., Eberhart-Phillips, D., Nicol, A., Mccaffrey, R., Beavan, J., Ellis, S., Power, W., Henrys, S., Sutherland, R., Litchfield, N., Townend, J., Robinson, R., Barker, D. H. N., and Wilson, K. 2008. Characterizing the seismogenic zone of a major plate boundary subduction thrust: The Hikurangi Margin, New Zealand (under revision).

Wang, N. 2001. Optically stimulated luminescence dating techniques and Application to Late Quaternary loess in southern North Island, New Zealand [M. Sc. thesis]: Victoria University of Wellington, 131 p. 
Wang, N., and Grapes, R. 2007. Infrared-stimulated luminescence dating of late Quaternary aggradation surfaces and their deformation along an active fault, southern North Island of New Zealand: Geomorphology, v. doi:10.1016/j.geomorph.2007.07.016.

Wellman, H. W. 1955. New Zealand Quaternary Tectonics. Geologische Rundschau, v. 43, p. $248-257$.

Wesnousky, S. G. 1988. Seismological and structural evolution of strike-slip faults: Letters to Nature, v. 335, p. 340-343.

Wilcox, R. E., Harding, T. P., and Seely, D. R. 1973. Basic Wrench Tectonics: AAPG Bulletin, v. 57, p. 74-96.

Xu, X., Wen, X., Yu, G., Chen, G., Klinger, Y., Hubbard, J., and Shaw, J. 2009. Coseismic reverse- and oblique-slip surface faulting generated by the $2008 \mathrm{Mw} 7.9$ Wenchuan earthquake, China: Geology, v. 37, no. 6, p. 515-518.

Yeats, R. S., Sieh, K., and Allen, C. R. 1997. The Geology of Earthquakes. Oxford University Press, New York, 568 pp.

Zachariasen, J., Villamor, P., Lee, J. M., Lukovic, B., and Begg, J. G. 2000. Late Quaternary faulting of the Masterton and Carterton faults, Wairarapa. GNS Client Report 2000/71.

Zhang, P-Z., Molnar, P., and Xu, X. 2007. Late Quaternary and present-day rates of slip along the Altyn Tagh Fault, northern margin of the Tibetan Plateau: Tectonics, v. 26, doi: 1029/2006TC002014 
Appendices 
A Fields Methods, Data Reduction, and Modelling 


\section{A1 Real-Time Kinematic Global Positioning System field methods}

The position (Easting, Northing, elevation) of selected points on the landscape along the Wairarapa Fault at the Waiohine River terraces, and at two pressure bulges just south of the Waiohine River were collected during several surveys using a Trimble R8 GNSS Real-Time Kinematic (RTK) Global Positioning System (GPS). RTK GPS was most effective at collecting points in open areas, where dense trees and bush cover did not impede the RTK rover from obtaining an adequate satellite lock.

During each survey at each site, the RTK base station was set up on a levelled tripod, over a monument or marker of precisely known location. The base stations also continually logged their location throughout the survey. The RTK rover was set up on a pole in a backpack allowing points to be rapidly collected while walking over the pressure bulges and terrace sequence. The heights of the base station and the rover (while worn in the backpack) were measured using a steel measuring tape. The rover and base station communicated with each other via radio link. Occasionally radio link was lost due to dense vegetation or high topography blocking the radio signal. A repeating device was set up on a topographic high point to repeat the signals between the base station and the rover, when they could not communicate directly.

The rover and base station were controlled by a handheld computer that communicated with them using Bluetooth. Survey settings were controlled with the handheld computer. New job files were created for each new survey at the Waiohine terraces, while at each pressure bulge a new job file was created and that same file was added to during successive surveys. Details of the location of the base station were entered if known, or logging of the base stations location was initiated. The heights of the base station and the rover above ground level were entered and the type of survey was specified. Points were collected using the continuous topo survey function, where points were collected automatically at a designated distance interval $(2 \mathrm{~m})$, or the measure points survey function, where points were only collected when manually instructed. The continuous topo survey function was more useful for covering large areas relatively quickly, while the measure points survey function was more useful in areas where satellite lock or radio link were not reliable, such as around trees and dense bush, and for collecting important labelled points such as EDM control stations.

In the January 2007 survey, the base station was set up over 1222 (Woodside) geodetic mark, $\sim 3 \mathrm{~km}$ south of the Waiohine terraces (Table A2-1), and precise locations (eastings, 
northings and elevations) of the 2007 EDM control stations (100 to 121) were obtained, and $>15,000$ points were collected across the terraces, risers and Wairarapa Fault scarp. Further RTK surveys at the Waiohine River terraces were carried out on five different days from January to April 2008, during which, $>3,000$ points were collected across the terrace sequence, across the reported paleochannels in the Waiohine surface, and the locations of OSL samples collected during this study and by Wang (2001). A base station marker peg was established on terrace $\mathrm{B}$ at the Waiohine terraces that was reoccupied in all but one of the surveys. Base stations RTCM0003, RTCM0004, RCTM0010 and RTCM2304 all occupied this marker (Figure A1-1, Table A2-2). Base station RTCM0001 occupied a marker peg on terrace $C$ at the Waiohine terraces (Figure A1-1, Table A2-2). At the large pressure bulge just south of Waiohine River, surveys were carried out on four different days during January through to April, 2008. In these surveys a base station marker peg was established on top of the pressure bulge that was reoccupied in each of the surveys (RTCM0001, occupied in the first two surveys, and RTCM2000, occupied in the second two surveys). A total of $>30,000$ points were collected across the entire bulge and the surrounding area (Figure A1-2, Table A2-3). A one-day RTK GPS survey was carried out at the smaller pressure bulge to the southwest of the large bulge in May, 2008. In this survey, a base station (RTCM2805) was established on top of the pressure bulge. A total of $>3,000$ points were collected during the survey across the entire bulge and the surrounding area, as well as from a meandering paleochannel on the downthrown side of the fault adjacent to the bulge (Figure A1-3, Table A2-4).

Uncertainties in the location of each point in each survey are introduced by several sources during data collection. One source of uncertainty is the accuracy with which the base station marker was reoccupied during different surveys of the terraces and pressure bulges, quantified as $\pm 0.5 \mathrm{~mm}(2 \sigma)$. Another source of uncertainty was introduced while measuring the heights above ground level of the RTK rover and RTK base station. These two measurements are made with a steel measuring tape and can result in a vertical error of $\pm 20 \mathrm{~mm}(2 \sigma)$, which is insignificant compared to other sources of uncertainty in the vertical measurements. A third source of uncertainty is that the number of satellites with lock on the base station or rover fluctuates during a survey. If this number falls below $\sim 7$, or if the dilution of precision of the satellites is reduced, as the result of dense tree or bush cover or high topography, the accuracy of a point's location is dramatically reduced. This is reflected by the points RMS value, and such points are easily removed from the survey data. 


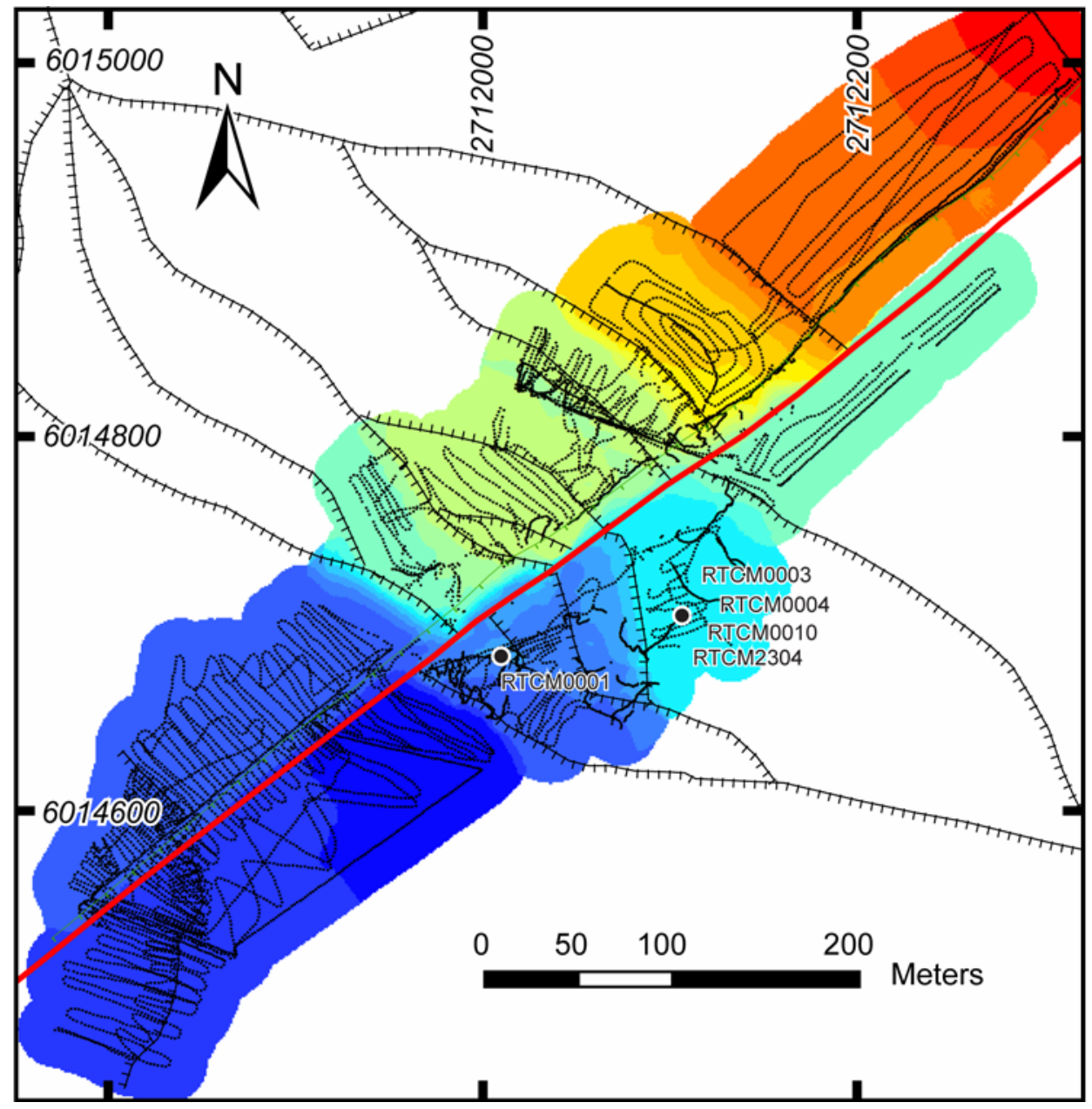

Figure A1-1. RTK base stations and survey points from the 2008 surveys at the Waiohine terraces. All base stations in these surveys were set up over the same marker peg at the Waiohine terraces, with the exception of RTCM0001. Large black circles are RTK base stations. Small black circles show entire RTK data set collected during the 2007 and 2008 surveys. 


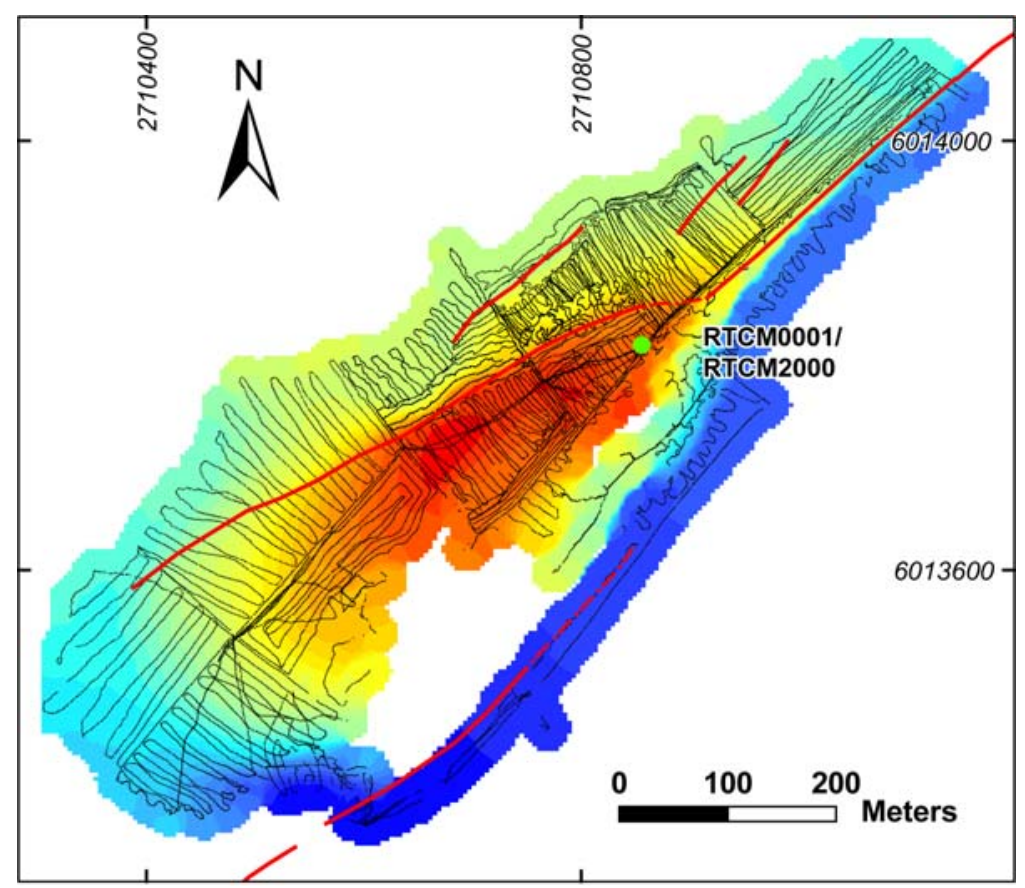

Figure A1-2. RTK GPS base stations and data points from the 2008 surveys at the large Type A pressure bulge just southwest of Waiohine River. Green dot is base station location. In all four surveys, base stations reoccupied the same marker peg. Small black dots are RTK GPS data points.

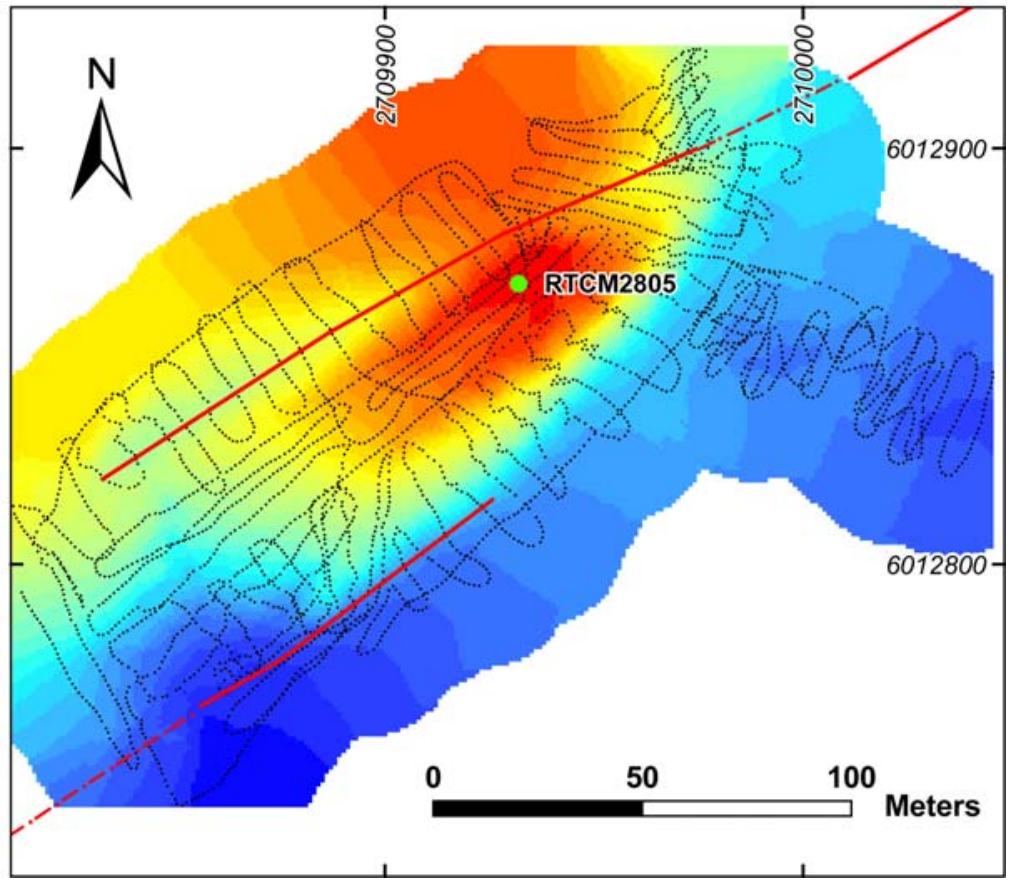

Figure A1-3. RTK GPS base station and data points from the 2008 survey at the small Type B pressure bulge just southwest of the larger bulge, southwest of Waiohine River. Green dot is location of base station. Small black dots are RTK GPS data points. 
The greatest source of uncertainty comes from the motion of the RTK rover as it is carried in the backpack during surveying. The rover cannot be kept exactly still while taking each point measurement, introducing an uncertainty in the easting and northing measurements, estimated as $\pm 10 \mathrm{~mm}(2 \sigma)$. The rover also does not remain in an upright position while climbing and descending hills during surveying, introducing an uncertainty in the vertical measurements where true elevations are higher than those recorded by the rover. This uncertainty was quantified as $\pm 180 \mathrm{~mm}(2 \sigma)$, calculated from the standard deviation of the differences in elevation of points within $1 \mathrm{~m}$ of each other between the 2007 and 2008 RTK GPS surveys at the Waiohine terraces (Appendix A2). The difference in elevation of closely spaced points as a result of the uneven topography at the Waiohine terraces (large boulders making up the terraces and risers) makes this uncertainty insignificant when interpreting Digital Elevation Models (DEM) generated from this data. 


\section{A2 Real-Time Kinematic Global Positioning System data reduction}

In the 2007 RTK GPS survey at the Waiohine terraces, the base station occupied 1222 (Woodside) geodetic mark, and the geodetic mark NZMG coordinates (6011862.6 N, 2710813.8 E, $86.5 \mathrm{~m}$ asl, available from http://www.linz.govt.nz/geodetic/geodeticdatabase) were entered into the handheld controller at the beginning of the survey (Table A2-1). No corrections needed to be applied to the 2007 survey data. In each of the 2008 RTK GPS surveys at the Waiohine terraces, base stations reoccupied the same (arbitrarily chosen) marker peg location on terrace $\mathrm{B}$ at the Waiohine terraces but were given new names in each survey (RTCM0003, RTCM0004, RTCM0010 and RTCM2304), except RTCM0001, which was located on terrace C. In each of the 2008 RTK GPS surveys at the large pressure bulge, base stations reoccupied the same (arbitrarily chosen) marker peg location at the top of the bulge, but the base station for the first two surveys (RTCM0001) had a different name to that used in the second two surveys (RTCM2000). In the 2008 survey at the smaller pressure bulge, the base station (RTCM2805) occupied an arbitrarily chosen marker peg at the top of the bulge.

RTK GPS data collected by the rover during each of the 2008 surveys at the Waiohine terraces and the two pressure bulges were transferred from the Trimble handheld controller to computer via USB. They were opened the GPS processing software, Trimble Geomatics Office (TGO). Data collected by the base stations were transferred to computer and opened in TGO where they were processed in conjunction with the LINZ continually logging geodetic mark MAST (Masterton). The phase information (navigation and observation files) for the Masterton trig station on the survey days was downloaded from www.positionz.co.nz. These files were imported into TGO where the Masterton trig station was given the highest (high) quality control and the survey base stations (RTCMXXXX) were given mapping (poor) quality control, meaning that the MAST station was fixed, and the RTCMXXXX stations could be moved. The baselines between the base stations and the Masterton trig station were processed to remove ionospheric and tropospheric delays, and the integer phase ambiguity was estimated. Once the baselines were calculated, all the data points collected by the rover in each of the surveys were recomputed. Points with high RMS errors were removed.

Corrected 2008 base station locations are shown in Tables A2-1, A2-2, A2-3 \& A2-4. The difference in location of each base station that occupied the same marker (Figure A1-1, Tables A2-2 \& A2-3) could be the result of phase processing imprecisions affecting the 
baseline when calculating the location of the base station with respect to MAST. This uncertainty is so minimal at the Waiohine terraces that it was ignored when combining data from different surveys. The relative positions of the points with respect to one another have an even smaller uncertainty, and it is the relative position of points at the Waiohine terraces that is important in this study. For the surveys the large pressure bulge, a translation (-0.014 m east, $-0.001 \mathrm{~m}$ north and $-0.009 \mathrm{~m}$ vertical) was applied to base station RTCM2000 (and all points collected during that survey), to make its location the same as the corrected location of base station RTCM0001.

The 2008 processed data were converted in TGO from WGS84 to NZMG. The TGO conversion did not use the latest LINZ transformation method resulting in a distortion on the metre level between eastings and northings calculated by TGO and those calculated by LINZ. The distortion was a consistent displacement of points in the 2008 surveys, with the relative distance of points in the surveys not affected over the small survey area. However, the distortion was evident when the 2007 and 2008 surveys at the Waiohine terraces were combined. The joining of 2007 and 2008 surveys at this site required a small translation to be applied to all points in the 2008 surveys (RTK GPS and EDM). The translation was determined by exporting the WGS84 coordinates for the 2008 surveys and converting them online to NZMG, and comparing those values to the NZMG coordinates calculated using TGO. The difference between the eastings and northings calculated online and those using TGO was $-2.260 \mathrm{~m}$ east and $-1.397 \mathrm{~m}$ north. After the translation was applied, the eastings and northings of the 2008 survey data precisely matched the 2007 survey data, indicated by a 2007 EDM control point that was resurveyed in 2008. A second translation (-0.073 $\mathrm{m}$ east, $-0.970 \mathrm{~m}$ north and $-2.902 \mathrm{~m}$ vertical) was applied to base station RTCM2304 (and all points collected during that survey), to make its location the same as the corrected location of base station RTCM0004.

The elevation data for the 2007 and 2008 surveys did not sufficiently match. The elevations of points within one metre of each other in the 2007 and 2008 surveys were differenced to find a value with which to shift the 2008 survey data (RTK GPS and EDM) in a vertical direction to match the 2007 survey data. A shift of $-0.502 \mathrm{~m}$ vertical was applied to all points in the 2008 surveys. The standard deviation of the vertical measurements was $\sim 13$ $\mathrm{cm}$, larger than the raw GPS precisions. For the 2007 and 2008 data sets, an uncertainty in the vertical measurements of $\pm 18 \mathrm{~mm}(2 \sigma)$ was calculated (Appendix A1). The uncertainty in the eastings and northings of the RTK GPS base stations and the associated survey points is $\pm 10 \mathrm{~mm}(2 \sigma)$ (Appendix A1). 
Table A2-1. RTK base station location from the 2007 survey at the Waiohine terraces. The base station occupied the 1222 (Woodside) geodetic mark $\sim 3 \mathrm{~km}$ south of the Waiohine terraces. Coordinates are NZMG, consistent with LINZ.

\begin{tabular}{|c|c|c|c|c|c|c|c|}
\hline Name & Northing & Easting & Elevation & $\begin{array}{c}\text { Coordinate } \\
\text { quality }\end{array}$ & $\begin{array}{c}\text { Std Dev } \\
\text { North }\end{array}$ & $\begin{array}{c}\text { Std Dev } \\
\text { East }\end{array}$ & $\begin{array}{c}\text { Std Dev } \\
\text { Elevation }\end{array}$ \\
\hline Woodside & 6011862.630 & 2710813.820 & 86.4906 & 0 & 0 & 0 & 0 \\
\hline
\end{tabular}

Table A2-2. RTK base stations from the six different 2008 surveys at the Waiohine terraces. The base stations in each of the surveys occupied the same marker peg, with the exception of RTCM0001, which occupied a different marker. A translation was applied to all the base station coordinates and their corresponding surveys to make them consistent with LINZ in NZMG and the 2007 data set. A correction was applied to RTCM2304 and the corresponding survey points to correct for the difference between the RTCM2304 base station coordinates and base station RTCM0004 which occupied the same marker.

\begin{tabular}{|c|c|c|c|c|c|c|}
\hline Name & Northing & Easting & Elevation & Horizontal Precision & Vertical Precision & RMS \\
\hline RTCM0001 & 6014682.785 & 2712010.546 & 94.353 & 0.008 & 0.01 & 0.018 \\
\hline RTCM0003 & 6014705.065 & 2712106.031 & 98.892 & 0.002 & 0.003 & 0.011 \\
\hline RTCM0004 & 6014705.060 & 2712106.022 & 98.887 & 0.002 & 0.003 & 0.019 \\
\hline RTCM0010 & 6014705.052 & 2712106.023 & 98.746 & 0.002 & 0.003 & 0.016 \\
\hline RTCM2304 & 6014705.060 & 2712106.022 & 98.887 & 0 & 0 & 0 \\
\hline
\end{tabular}

Table A2-3. RTK base stations from the four different 2008 surveys (2 surveys using each basestation) at the large pressure bulge, southeast of Waiohine River. The base stations in each of the surveys occupied the same marker peg. A correction was applied to RTCM2000 and the points in the corresponding two surveys to correct for the difference between the RTCM2000 base station coordinates and base station RTCM0001 which occupied the same marker.

\begin{tabular}{|c|c|c|c|c|c|c|}
\hline Name & Northing & Easting & Elevation & Horizontal Precision & Vertical Precision & RMS \\
\hline RTCM0001 & 6013809.637 & 2710855.960 & 137.538 & 0.002 & 0.004 & 0.014 \\
\hline RTCM2000 & 6013809.638 & 2710855.974 & 137.547 & 0.001 & 0.002 & 0.014 \\
\hline
\end{tabular}

Table A2-4. RTK base station for the 2008 survey at the small pressure bulge, further southeast of Waiohine River.

\begin{tabular}{|c|c|c|c|c|c|c|}
\hline Name & Northing & Easting & Elevation & Horizontal Precision & Vertical Precision & RMS \\
\hline RTCM2805 & 6012867.410 & 2709931.949 & 117.059 & 0.001 & 0.002 & 0.017 \\
\hline
\end{tabular}




\section{A3 Electronic Distance Meter field methods}

Topographic data points were collected at the Waiohine River terraces using a Sokkia 3030R Electronic Distance Meter (EDM) in areas where RTK GPS methods were less accurate or impossible, such as in areas of dense tree or bush cover.

Two EDM surveys of the Waiohine terraces were made (January 2007 and January 2008). In each survey control stations were chosen and marked by a wooden or plastic stake driven into the ground. Their locations were chosen where at least one other control point could be sighted, and in an area where as little vegetation as possible would interfere with the survey point collection. The locations of the control points were determined by RTK GPS. Some control point locations could not be determined with GPS due to dense tree or bush cover that would not allow the GPS rover to obtain satellite lock. The locations of those points were later determined using EDM measurements relative to another known control point (Appendix A4).

The first survey was in January 2007. Twenty two control points (labelled 100 to 121) were defined (Figure A3-1). The January 2007 RTK GPS survey (Appendices A1 and A2) surveyed in the precise locations of all but four of those control points (101, 105, 108 and 112). The second survey was in January 2008. Six new control points (labelled 200 to 205) were defined (Figure A3-1). The RTK GPS survey using base station RTCM0004, surveyed in the precise location of all but one of those control points (203).

The EDM was moved between control point pairs for 20 individual surveys in 2007, and four individual surveys in 2008. During each individual survey, the EDM was set up over one of the control points, and a reflector was sighted at a second control point to form a baseline for azimuthal control of subsequent measurements. The height of the EDM or reflector at each control point above ground level was recorded so that corrections for height could be made where RTK GPS measurements were not obtained. As an external check of the EDM, the true bearing between control points was measured for a comparative reference.

The height of a reflector attached to a stadia rod was recorded, and then the reflector was moved over the topography to various points while the horizontal and vertical angles and slope distance to each point with respect to the baseline were recorded. In the 2007 surveys, points were given a label according to their location at the site (e.g. station 101, 
terrace A, riser BC, or scarp). More than 400 points were collected in 2007 and $>200$ points were collected in 2008 (Figure A3-1).

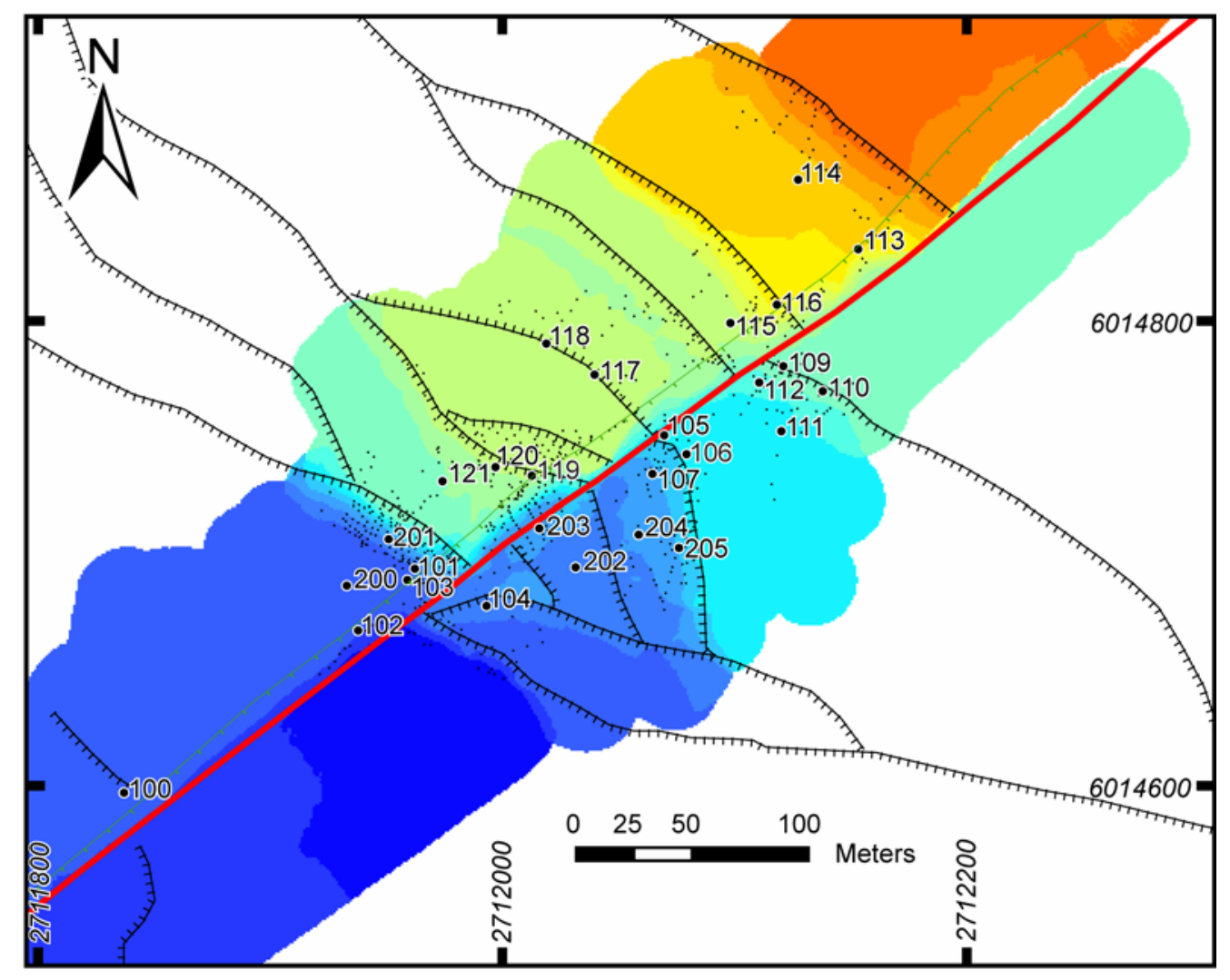

Figure A3-1. EDM control points and survey points from the 2007 (100-121) and 2008 surveys at the Waiohine terraces. Labelled large black circles are EDM control points, locations of which were determined during 2007 and 2008 RTK GPS surveys. Small black cirles show entire EDM data set collected during the 2007 and 2008 surveys. Control point 108 was removed from the survey and is not shown. 


\section{A4 Electronic Distance Meter data reduction}

The EDM recorded point location data onto a memory card, the vertical and horizontal angle and slope distance with respect to the baseline for each point in each survey. The data were transferred to computer and opened in the Mapsuite program. From Mapsuite they were copied and pasted into Microsoft Excel to be edited. Azimuths (horizontal angles) and zenith distances (angle from vertical) were converted from decimal degrees $\left(100\right.$ gons $=90^{\circ}$ and 400 gons $\left.=360^{\circ}\right)$. Zenith distances were then subtracted from $90^{\circ}$, so that positive angles were upwards and negative angles were downwards with respect to a horizontal plane.

In the 2007 RTK GPS survey, four control point locations (101, 105, 108 and 112) could not be determined (dense bush cover did not allow a satellite lock), and the locations of control points 106 and 107 had lower precision (poor dilution of precision) than the other control points (Table A4-1). In the 2008 RTK GPS (RTCM0004) survey, the location of control points 201 and 203 could not be determined (dense bush cover did not allow a satellite lock).

For each of these control points with an unknown or lower precision location, the true locations were calculated using EDM data and the RTK GPS position determined for another control point. The vertical angle and slope distance between two control points (one with a precise location, one without) could be used with trigonometry to find the horizontal distance between the two control points (Figure A4-1a). This distance was converted into a difference in eastings and northings between the two points using trigonometry and the measured compass bearing (Figure A4-1b). The differences were added to the RTK GPS-defined location of the known control point to determine the location the unknown or low precision control point. The difference in height above ground level (if any) of the two control points was corrected for.

For each survey between a particular control point pair, the eastings, northings and elevation (Tables A4-1 and A4-2) and height above ground level of each control point in the pair were entered into an Excel calculator, along with the horizontal and vertical angles, slope distance, and bearing between the control point pair, and the stadia rod height. Using the edited horizontal and vertical angles, and slope distance data for each survey, the easting, northing and elevation for every point in each survey was calculated. For each pair 
of RTK GPS-defined control points, the calculated azimuth between the two control points was the same as the measured compass bearing.

The easting, northing and elevation data obtained from the EDM calculator were combined with their respective RTK GPS data. Corrections applied to the RTK GPS data (and the control point locations) were then also applied to the EDM data.

Table A4-1. RTK GPS coordinates for EDM control points from the 2007 surveys at the Waiohine River terraces. Locations were determined by RTK GPS where possible, relative to the RTK GPS base station at 1222 (Woodside) geodetic marker. Controls points 106 and 107 have poorer coordinate quality and were checked with EDM measurements. Control points 101, 105 and 112 could not be determined by RTK GPS due to dense tree or bush cover, and were calculated using EDM measurements (see text for full description). Uncertainty in the northings, eastings and elevations of these three control point locations are estimated as $\pm 0.4 \mathrm{~m}$. Control point 108 was removed from the survey as it was not occupied or used during any of the surveys, and its location was not determined by RTK GPS. Coordinates are New Zealand Map Grid, consistent with LINZ.

\begin{tabular}{|c|c|c|c|c|c|c|c|}
\hline Name & Northing & Easting & Elevation & $\begin{array}{c}\text { Coordinate } \\
\text { Quality }\end{array}$ & $\begin{array}{c}\text { Std Dev } \\
\text { North }\end{array}$ & $\begin{array}{c}\text { Std Dev } \\
\text { East }\end{array}$ & $\begin{array}{c}\text { Std Dev } \\
\text { Elev }\end{array}$ \\
\hline 100 & 6014597.165 & 2711837.235 & 91.319 & 0.031 & 0.017 & 0.010 & 0.024 \\
\hline 101 & 6014693.875 & 2711962.576 & 92.535 & - & - & - & - \\
\hline 102 & 6014667.237 & 2711938.025 & 90.855 & 0.037 & 0.024 & 0.011 & 0.027 \\
\hline 103 & 6014688.695 & 2711959.201 & 91.594 & 0.034 & 0.020 & 0.010 & 0.025 \\
\hline 104 & 6014677.656 & 2711993.164 & 93.177 & 0.042 & 0.018 & 0.009 & 0.036 \\
\hline 105 & 6014751.026 & 2712069.888 & 98.384 & - & - & - & - \\
\hline 106 & 6014742.546 & 2712079.315 & 97.824 & 0.610 & 0.260 & 0.232 & 0.501 \\
\hline 107 & 6014734.195 & 2712064.625 & 95.037 & 0.143 & 0.023 & 0.016 & 0.140 \\
\hline 108 & - & - & - & - & - & - & - \\
\hline 109 & 6014780.578 & 2712121.031 & 103.132 & 0.046 & 0.022 & 0.015 & 0.037 \\
\hline 110 & 6014769.989 & 2712138.044 & 102.880 & 0.032 & 0.018 & 0.008 & 0.025 \\
\hline 111 & 6014752.675 & 2712120.173 & 98.683 & 0.042 & 0.019 & 0.014 & 0.034 \\
\hline 112 & 6014773.618 & 2712110.712 & 100.769 & - & - & - & - \\
\hline 113 & 6014831.104 & 2712153.223 & 113.804 & 0.030 & 0.016 & 0.009 & 0.023 \\
\hline 114 & 6014861.127 & 2712127.439 & 113.941 & 0.038 & 0.029 & 0.007 & 0.024 \\
\hline 115 & 6014799.210 & 2712098.252 & 106.804 & 0.040 & 0.022 & 0.013 & 0.031 \\
\hline 116 & 6014806.958 & 2712118.312 & 112.827 & 0.034 & 0.019 & 0.011 & 0.026 \\
\hline 117 & 6014777.143 & 2712039.685 & 106.800 & 0.034 & 0.021 & 0.010 & 0.024 \\
\hline 118 & 6014790.348 & 2712018.941 & 106.946 & 0.051 & 0.028 & 0.017 & 0.039 \\
\hline 119 & 6014733.488 & 2712012.851 & 106.529 & 0.029 & 0.019 & 0.009 & 0.021 \\
\hline 120 & 6014737.160 & 2711997.102 & 106.444 & 0.032 & 0.019 & 0.011 & 0.024 \\
\hline 121 & 6014731.020 & 2711974.261 & 103.835 & 0.021 & 0.014 & 0.006 & 0.014 \\
\hline
\end{tabular}


Table A4-2. RTK GPS coordinates for EDM control points from the 2008 surveys at the Waiohine River terraces. Locations were determined by RTK GPS where possible, relative to the RTK GPS base station RTCM0004. Control points 201 and 203 could not be determined by RTK GPS due to dense tree or bush cover, and were calculated using EDM measurements (Figure A4-1). Uncertainty in the northings, eastings and elevations of these two control point locations are estimated as $\pm 0.4 \mathrm{~m}$. A correction was applied to all the control point coordinates and their corresponding surveys to make them consistent with LINZ in NZMG and the 2007 data set.

\begin{tabular}{|c|c|c|c|c|c|c|}
\hline Name & Northing & Easting & Elevation & $\begin{array}{c}\text { Horizontal } \\
\text { Precision }\end{array}$ & $\begin{array}{c}\text { Vertical } \\
\text { Precision }\end{array}$ & RMS \\
\hline 200 & 6014686.466 & 2711933.174 & 91.524 & 0.004 & 0.006 & 0.002 \\
\hline 201 & 6014706.518 & 2711951.22 & 94.538 & - & - & - \\
\hline 202 & 6014694.215 & 2712031.601 & 93.468 & 0.004 & 0.006 & 0.002 \\
\hline 203 & 6014711.123 & 2712015.834 & 95.523 & - & - & - \\
\hline 204 & 6014708.381 & 2712058.740 & 94.424 & 0.005 & 0.008 & 0.003 \\
\hline 205 & 6014702.816 & 2712076.086 & 96.108 & 0.004 & 0.005 & 0.003 \\
\hline
\end{tabular}




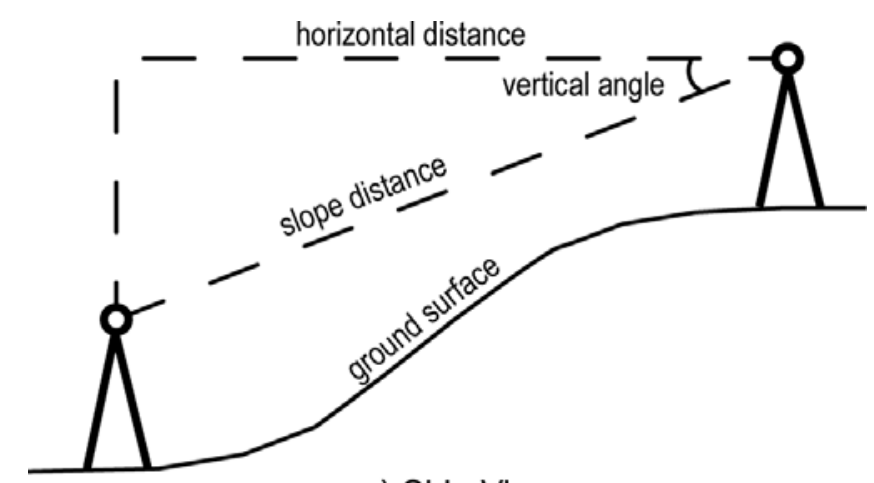

a) Side View

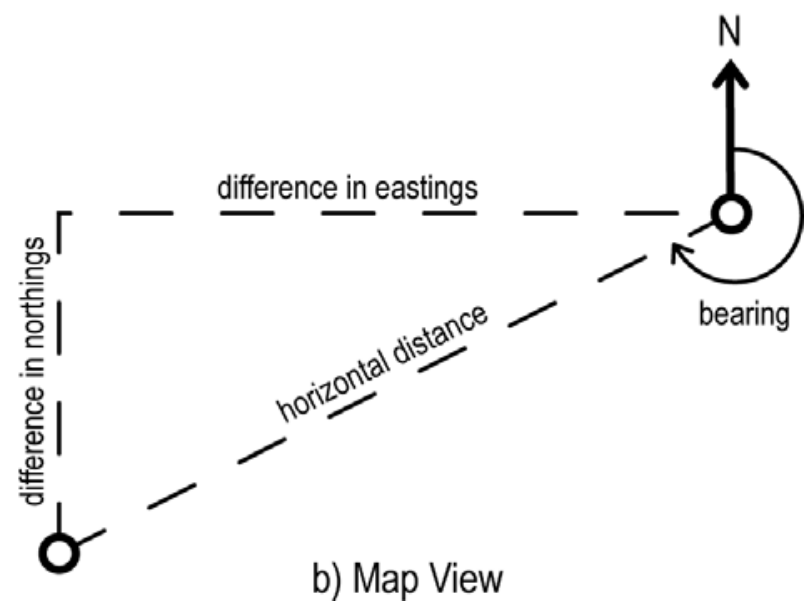

Figure A4-1. Method for calculating location of secondary EDM control points from RTK GPSdefined location of one control point, the EDM-measured slope distance, and the compassmeasured bearing between the two control points. a) Side view showing calculation of horizontal distance between two control points using trigonometry with the slope distance and vertical angle between the two control points. b) Map view showing calculation of the difference in eastings and northings using trigonometry with the measured compass bearing and the calculated horizontal distance between the two control points. The differences in eastings and northings are added RTK-GPS-defined location of the known control point to determine the location of the unknown or low precision control point. The difference in height above ground level of the two control points is corrected for. 


\section{A5 Producing and contouring Digital Elevation Models}

Several Digital Elevation Models (DEM's) of the Waiohine River terraces were produced from the combined 2007 and 2008 RTK GPS and EDM survey data (Figures 11a-f, Figure 4c, Figure 5 \& Figure A5-1). Two DEMS's were produced from the 2008 RTK GPS survey data, of the large pressure bulge to the west of the Waiohine River (Figure 24a), and the smaller pressure bulge slightly further southwest of the large bulge (Figure 24c).

DEM's are data files that contain the elevation of the terrain over a specified area at a fixed grid interval. The closer together the grid points are, the more detailed the information in the file will be. Details of peaks and streams in the terrain will be better modelled with a smaller grid spacing. Elevations other than at specific grid point locations are not contained in the file, and so peak and stream points not coincident with the grid, will not be recorded in the file.

The RTK and EDM data from different surveys at each site were combined in Excel. Points with large errors were removed and the data were saved as comma separated values (.csv) files. The .csv file was added as a new layer in an ArcMap document in the ArcGIS computer program. The points were displayed as XY data (eastings and northings) and assigned the New Zealand Map Grid (NZMG) coordinate system. The displayed points were then exported as a shape file and added as new layers to the ArcMap document.

The Spatial Analyst extension was opened in ArcMap. Using this extension, the combined RTK GPS and EDM shape file was interpolated to a Raster image (grid) with the Kriging function. The $Z$ value field was set to elevation, and an ordinary krigging method, a spherical semivariogram model, and a variable search radius type were selected. The search radius settings (number of points and maximum distance) were modified to create various DEM's allowing the most appropriate settings to be determined. All DEM's (those at Waiohine terraces and each of the two pressure bulges) used 12 points, and the maximum distance varied from $10 \mathrm{~m}$ (Figures 11a \& 11b) to $15 \mathrm{~m}$ (Figures 11c-f) to $20 \mathrm{~m}$ (Figure 4c, Figure 5, Figures 24a \& c and Figure A5-1). The effect of increasing the maximum distance was to smooth the DEM and extend it over a wider area where data points had not been collected. The specified output cell size varied for each DEM produced in order to determine the most appropriate settings. The effect of increasing the output cell size was to decrease the resolution of the DEM. An output cell size was specified that represented the average spacing of data points collected, so that false detail was not produced while true detail was 
not neglected. An output cell size of $1 \mathrm{~m}$ was specified for small scale DEM's (Figure 11a \& Figure 24c), 2 m output cell size for medium scale DEM's (Figures 11b-f, Figure 5), and $4 \mathrm{~m}$ output cell size for large scale DEM's (Figure 4c, Figure 24a \& Figure 5A-1). DEM's were made at various scales for the Waiohine terraces including large scale DEM's covering the entire terrace sequence so that the individual terraces and risers and the Wairarapa Fault scarp could easily be identified, and small scale DEM's covering each individual terrace riser or paleochannel offset across the fault. Less distinct topographic features (such as paleochannel $\mathrm{Ch} 2$ on the lowest degradation terrace) were more densely covered during RTK GPS and EDM surveys, allowing more detailed DEM's to be produced using a small output cell size.

Contouring of DEM's was done using the Spatial Analyst extension with the Surface AnalysisContouring function. Various contour intervals were specified for each DEM to determine an appropriate contour interval that showed considerable detail without significant overlapping of contours, or generation of contours that are artifacts of the data. The produced contours were saved as shape files and added as new layers to the ArcMap document. 


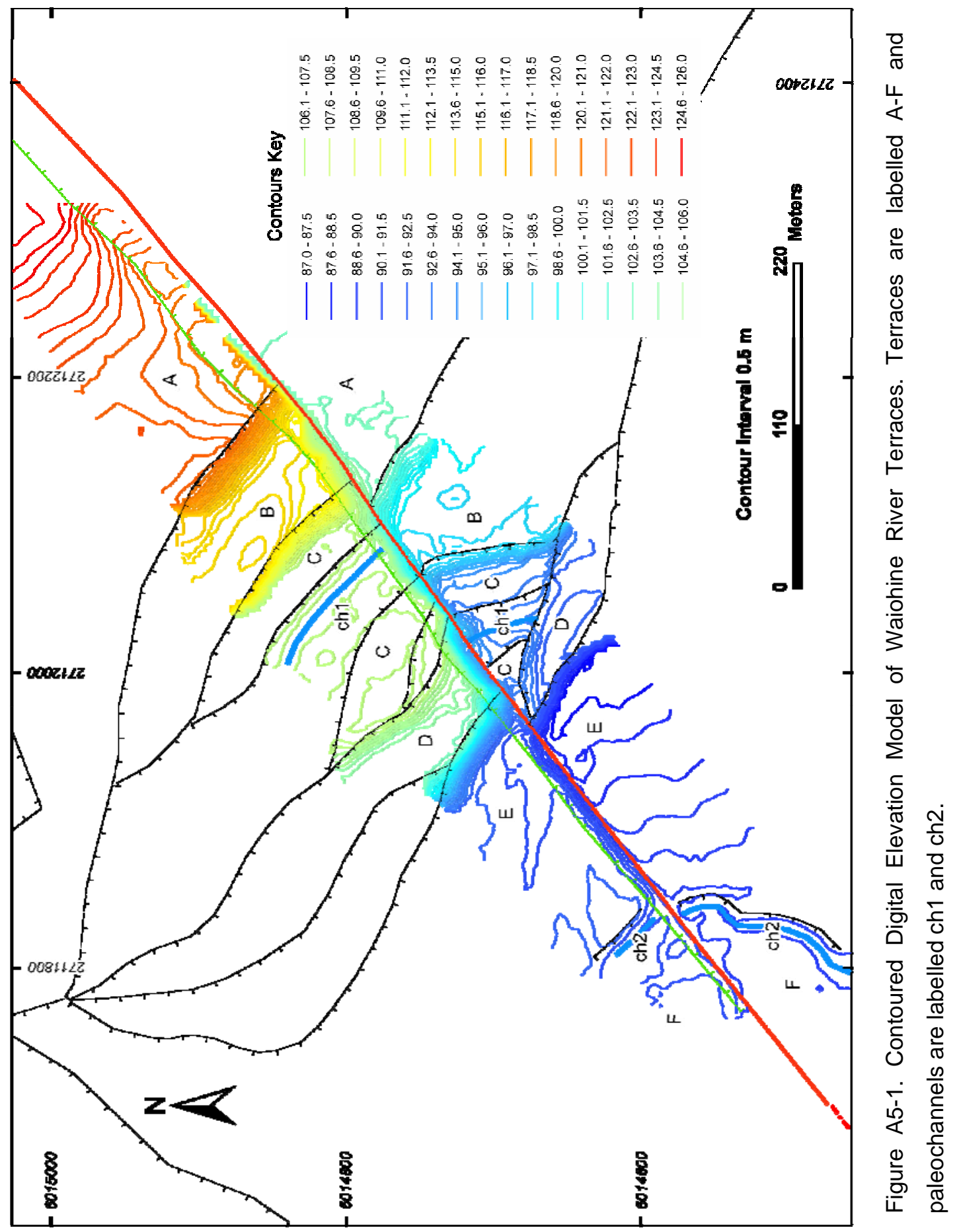




\section{A6 Producing Triangulated Irregular Networks}

Triangulated Irregular Networks (TIN's) were produced using RTK GPS data for the large pressure bulge to the west of the Waiohine River (Figure 24b), and the smaller pressure bulge slightly further southwest of the large bulge (Figure 24d).

TIN's are vector-based representations of the physical land surface, and are made up of irregularly distributed nodes and lines with three-dimensional coordinates that are arranged in a network of non-overlapping triangles. Points in a TIN are distributed variably based on the algorithm that determines which points are most necessary to give an accurate representation of the terrain. TIN's are able to more accurately portray terrain in $3 \mathrm{D}$, providing better control on terrain slope, aspect, surface areas, volumetric and cut-fill analyses, and generating contours.

The 3D Analyst extension was opened in Arc Map. Using this extension, the RTK and shape files for each site were defined as inputs to create each TIN, with the Create/Modify TIN-Create TIN From Features function. The settings for the selected layer (shape files) included the Feature type which was set as $2 \mathrm{D}$ points, the Height source which was set to elevation, and the TIN was set to Triangulate as mass points. The resulting TIN's for the two bulges are shown in Figures 24b \& d. 
B Interpretation of Wairarapa Fault Displacements at Waiohine Terraces 


\section{B1 Summary of displacements from previous studies at the Waiohine terraces}

Table B1-1. Previous interpretations of cumulative horizontal and vertical displacements at the Waiohine terraces by Grapes and Wellman (1988) and Lensen and Vella (1971). Riser equiv and Terrace equiv columns indicate the equivalent riser and terrace interpretation in this study. Lensen and Vella (1971) measured their vertical displacements with a level and rod, accurate to $\sim 0.15 \mathrm{~m}$, and their horizontal displacements with measuring tape, accurate to $\sim 0.9 \mathrm{~m}$. The displacement measurements reported by Grapes and Wellman (1988) were not accompanied by methodological explanations, survey data, or estimates of error. Grapes (1999) quantified the error for all horizontal and vertical displacements reported by Grapes and Wellman (1988) as \pm $1 \mathrm{~m}$.

\begin{tabular}{|c|c|c|c|c|c|c|c|}
\hline \multirow{2}{*}{$\begin{array}{c}\text { Grapes and Wellman, } 1988 \\
\text { Riser }\end{array}$} & \multicolumn{7}{|c|}{ (this study) } \\
\hline & Riser equiv & Horizontal slip (m) & Terrace & Terrace equiv & NW of fault & SE of fault & Vertical slip (m) \\
\hline Channel & - & 130 & Ag3 & AlWaiohine & 33.3 to 34.2 & 14.8 to 14.3 & 18.5 to 19.9 \\
\hline $\mathrm{Ag} 3 \mathrm{~A}$ & $A B$ & 97 & A & B & 25.8 & 10.9 & 14.9 \\
\hline$A B$ & $\mathrm{BC}$ & 84 & B & C & 18.6 & 6.8 & 11.8 \\
\hline $\mathrm{BC}$ & $\mathrm{CD}$ & 63 & C & D & 16 & 5.9 & 10.1 \\
\hline$C D$ & - & - & D & $D^{\prime}$ & - & - & - \\
\hline DE & $\mathrm{DE}$ & 32 & $E$ & $E$ & 3.7 & 2 & 1.7 \\
\hline $\mathrm{EF}$ & $\mathrm{EF}$ & 12 & $\mathrm{~F}$ & $\mathrm{~F}$ & 2.9 & 2 & 0.9 \\
\hline Lensen and Vella, 1971 & & & & (this study) & & & \\
\hline \multirow[t]{2}{*}{ Riser } & Riser equiv & Horizontal slip (m) & Terrace & Terrace equiv & NW of fault & SE of fault & Vertical slip (m) \\
\hline & & & A & A/Waiohine & 33 & 14.7 & 18.3 \\
\hline$A B$ & $A B$ & 99 & B & B & 26.1 & 11.4 & 14.7 \\
\hline$B C$ & $B C$ & 85.5 & C & C & 18.9 & 6.6 & 12.3 \\
\hline$C D$ & CCch & 66.9 & D & Cch & 18 & 6 & 12.0 \\
\hline $\mathrm{DE}$ & $C D$ & - & $E$ & $D$ & 16.2 & 6 & 10.2 \\
\hline $\mathrm{EF}$ & - & - & $\mathrm{F}$ & $D^{\prime}$ & - & - & - \\
\hline FG & $\mathrm{DE}$ & 32.1 & G & E & 3.6 & 0 & 3.6 \\
\hline $\mathrm{GH}$ & $\mathrm{EF}$ & 12 & $\mathrm{H}$ & $\mathrm{F}$ & 2.7 & 1.8 & 0.9 \\
\hline
\end{tabular}




\section{B2 Differences between our mapped interpretation and those of previous studies at the Waiohine terraces}

As determined from our new microtopographic maps, terrace $C^{\prime}$ is approximately $1 \mathrm{~m}$ lower in elevation than terrace $\mathrm{C}$ and the elevation of terrace $\mathrm{D}^{\prime}$ is topographically indistinct from that of terrace D (Figure 3). We interpret terrace C' to represent a paleotopographical incision into terrace $\mathrm{C}$, as it has the same elevation as paleochannel Ch1, incised into terrace $\mathrm{C}$, rather than to have formed in response to a discrete episode of later river downcutting. Terrace D' occurs just outside the area of our microtopographic map, however during field excursions, terraces D and D' were observed to have the same elevation, and were separated by what we interpret as a paleo-braid-bar. We distinguish between these two terraces on the basis of our aerial photo interpretation, where a line of trees that coincide with the location of the observed paleo-braid-bar mark the apparent border between the terraces. We also make this distinction for ease of comparison with Lensen and Vella's (1971) and Grapes and Wellman's (1988) interpretations, in which our terrace D' was mapped a separate terrace, terraces $F$ and $D$ in the respective studies (Figures 4a-c). Terrace C' defined in this study was named by Lensen and Vella as a separate terrace (Figure 4a), a landform which they also combined with paleochannel Ch1 (named terrace D in their study), while Grapes and Wellman (1988) did not distinguish what we are here calling terrace C' (Figure 4b). Moreover, they identified our Ch1 as a depression in our terrace $\mathrm{C}$ (their terrace B).

On the northwest side of the fault, our terraces D and D' are depicted by Lensen and Vella's (1971) as their terraces E and F. However, we do not map a terrace equivalent to their terrace $\mathrm{E}$ on the southeast side of the fault (Figures 4a \& 4c). Lensen and Vella (1971) interpret the so-called riser between terraces D and D' (their riser EF) to hit the fault (Figure 4a), while in this study, and that by Grapes and Wellman (1988) that riser (between their terraces $C$ and $\mathrm{D}$ ) is interpreted as being truncated by the next lower riser and not to hit the fault (Figures $4 \mathrm{~b} \& 4 \mathrm{c}$ ).

Riser CD is mapped in this study as hitting the fault at a smaller angle to the fault on the southeast side than the equivalent riser (riser CE) of Lensen and Vella's (1971), and as hitting the fault at a smaller angle to the fault on the northwest side than the equivalent riser (riser BC) of Grapes and Wellman's (1988). Our riser BC on the downthrown side of the fault and our riser $\mathrm{AB}$ on the upthrown side of the fault are interpreted to hit the fault 
at a greater angle to the fault than the equivalent landforms (riser $\mathrm{AB}$ and riser $\mathrm{Ag} 3 \mathrm{~A}$, respectively) identified by Grapes and Wellman (1988) (Figures 4b \& 4c). 
B3 Summary of displacements from this study at Waiohine terraces

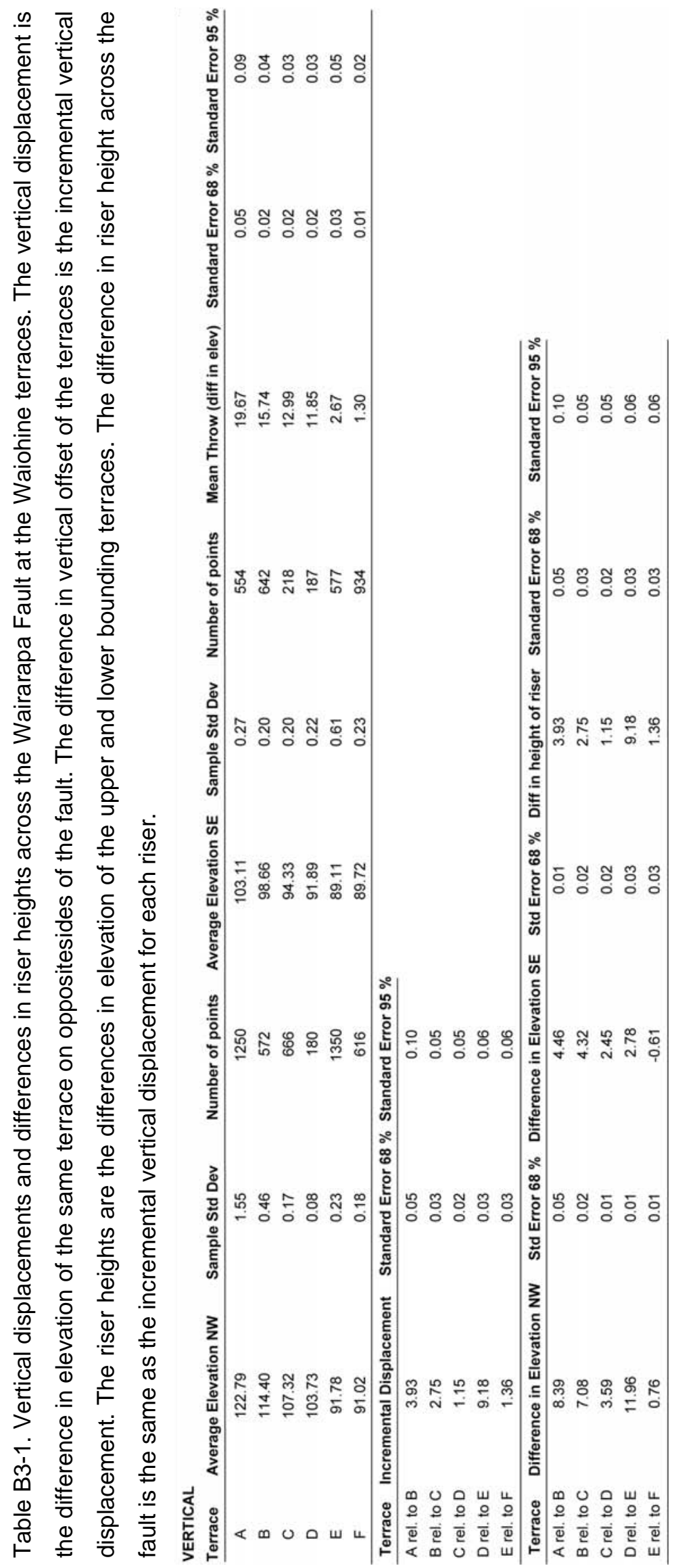




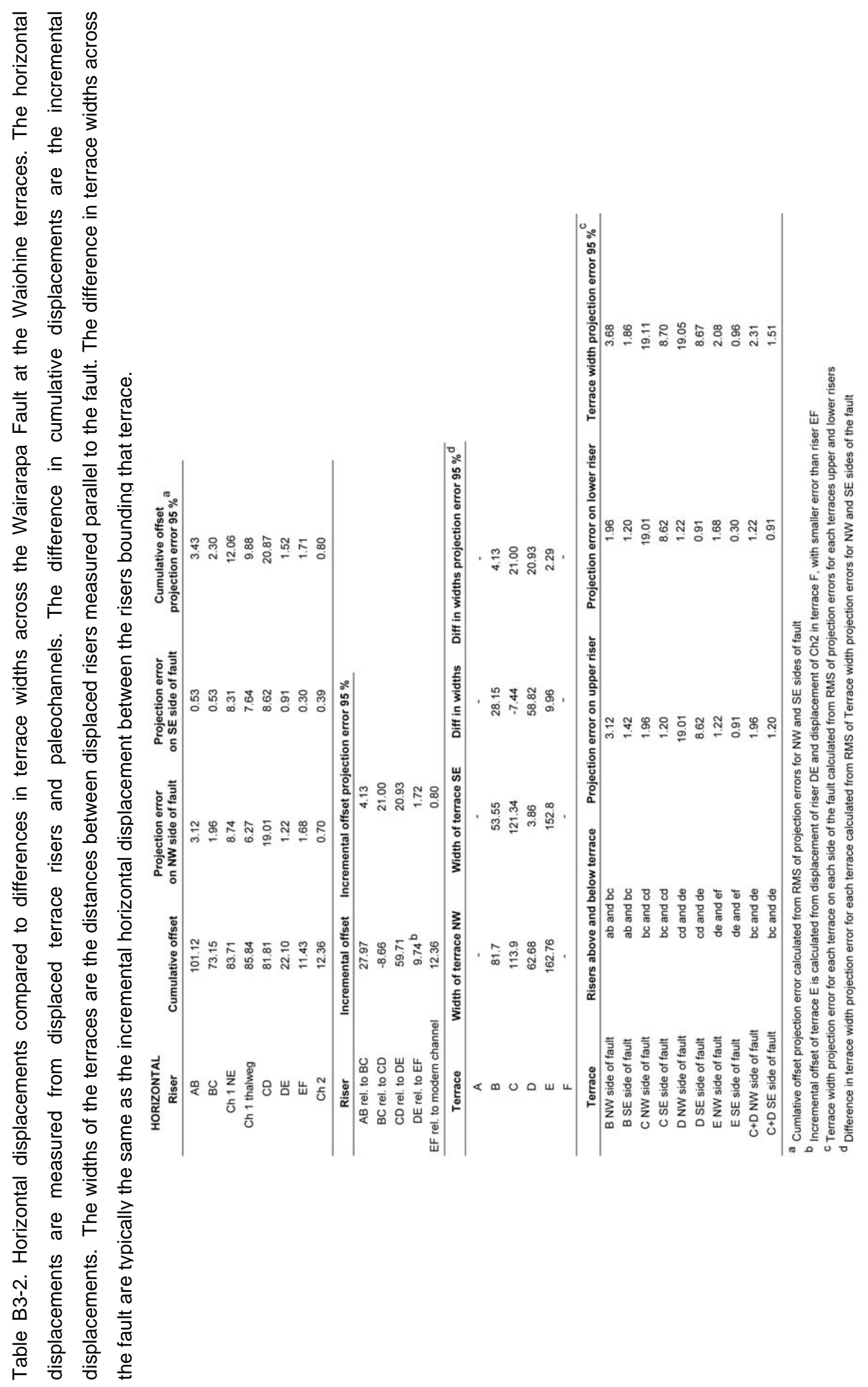

Carne, R. C. 


\section{B4 Differences between our measured displacements and those of previous studies at the Waiohine terraces}

For riser DE, Grapes and Wellman (1988) and Lensen and Vella (1971) reported dextral displacements $\sim 10 \mathrm{~m}$ larger than here presented (Table 3). This difference may be due to other parts of the riser being matched across the fault in the other studies. We note that the height of riser DE on the upthrown side of the fault is $\sim 9 \mathrm{~m}$ greater than on the downthrown side of the fault (Table 2), as would be expected in a case of complete erosional trimming where at least one earthquake took place during the time of river occupation of the lower terrace. In the previous studies, the symmetrical midpoints of the risers (rather than contour lines differing in height by the throw magnitude) were matched across the fault. This difference in choice of matched lines would be predicted to lead to a larger displacement measurement being made. As is correct for a complete trimming model, the contours on the riser that were matched by us across the fault in this study occur at identical elevations above the lower terrace surface, rather than geomorphically in the centre of the riser.

For riser BC, Grapes and Wellman (1988) and Lensen and Vella (1971) reported dextral displacements $\sim 10-12 \mathrm{~m}$ larger than here presented (Table 3). Again, this may be due to the difference in techniques used to measure the displacements as mentioned above. We note that the height of riser $\mathrm{BC}$ on the upthrown side of the fault is $\sim 3 \mathrm{~m}$ greater than on the downthrown side of the fault. 
C Ages of Waiohine Surface and Other Degradation Terraces at Waiohine River 


\section{C1 OSL and ${ }^{14} \mathrm{C}$ sample collection at Waiohine River}
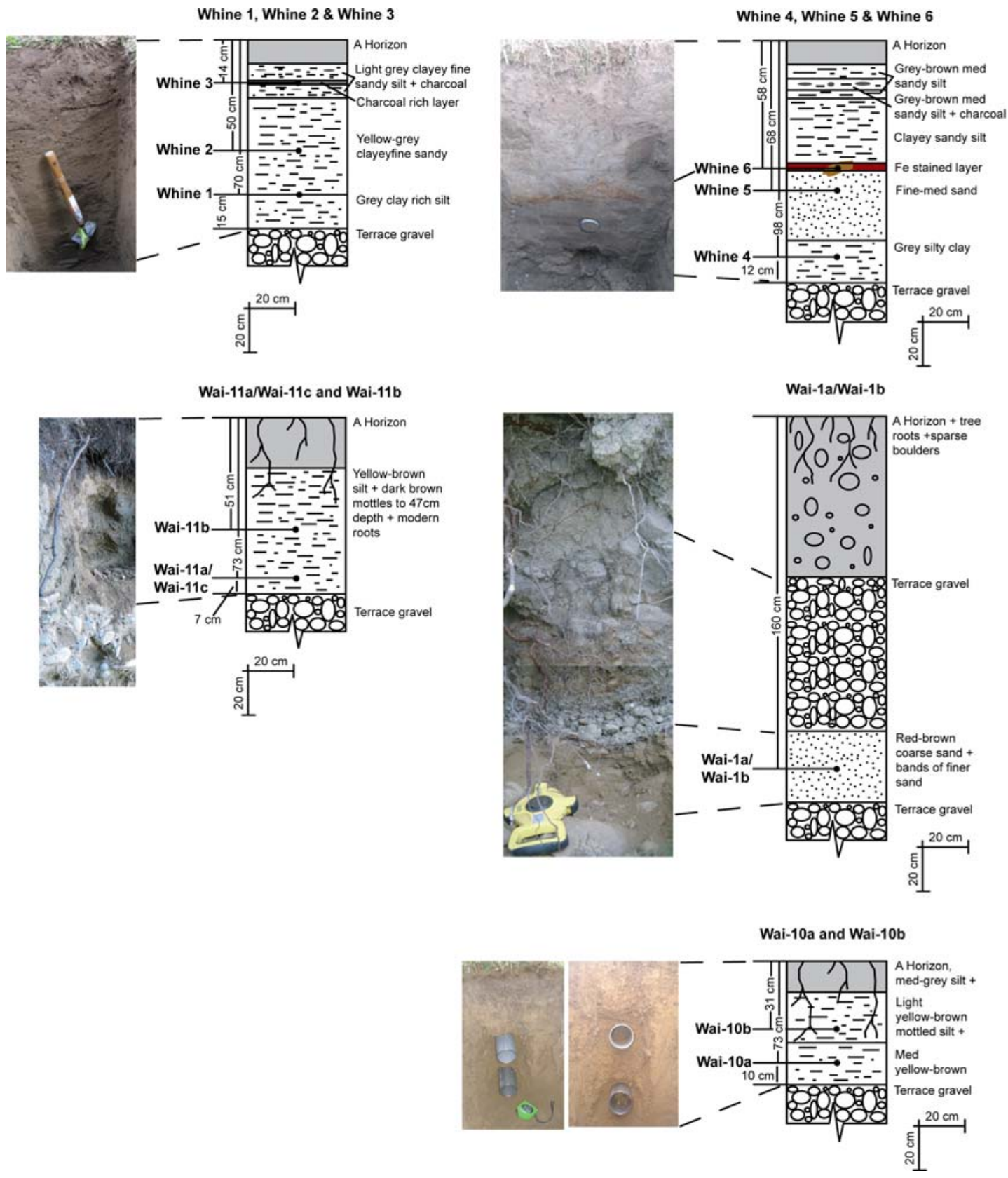

Figure C1-1. Stratigraphic columns and photos showing OSL and 14C samples collected at and near the Waiohine terraces. Samples Whine1, Whine 2 and Whine 3, Whine 4, Whine 5 and Whine 6 were collected from silts overlying terrace gravels on terrace $E$ at the Waiohine terraces. Whine 1-3 were collected on the upthrown side of the Wairarapa Fault, while Whine 46 were collected on the downthrown side. Samples Wai-10a and Wai-10b were collected from silts overlying terrace gravels on terrace $B$ at the Waiohine terraces, on the downthrown side of the fault. Samples Wai-1a and Wai-1b were collected from sands within terrace gravels of terrace B and samples Wai-11a, Wai $11 \mathrm{~b}$ and Wai-11c were collected from silts overlying terrace gravels of terrace $B$ from the Waiohine River bank on the western side of the river (opposite side of the river to the Waiohine terrace site), on the upthrown side of the Wairarapa Fault. 


\section{C2 Results of OSL Dating of Samples from Terraces B and E at Waiohine River}

Table C2-1. Radionuclide and water contents

\begin{tabular}{|c|c|c|c|c|c|}
\hline $\begin{array}{c}\text { Sample } \\
\text { no. }\end{array}$ & $\begin{array}{c}\text { Water } \\
\text { content } \\
\delta^{1}\end{array}$ & $\begin{array}{c}\mathrm{U}(\mu \mathrm{g} / \mathrm{g})^{2} \\
\mathrm{from}{ }^{226} \mathrm{Ra},\end{array}$ & $\begin{array}{c}\mathrm{Th}(\mu \mathrm{g} / \mathrm{g})^{2} \\
\mathrm{from}{ }^{208} \mathrm{Tl},\end{array}$ & $\mathrm{K}(\%)$ & Field code \\
\hline WLL651 & 1.250 & $3.70 \pm 0.23$ & $15.5 \pm 0.2$ & $2.86 \pm 0.06$ & Whine 1 \\
\hline WLL652 & 1.228 & $3.36 \pm 0.23$ & $14.9 \pm 0.2$ & $2.71 \pm 0.06$ & Whine 2 \\
\hline WLL653 & 1.236 & $2.92 \pm 0.21$ & $14.0 \pm 0.2$ & $2.73 \pm 0.06$ & Whine 4 \\
\hline WLL654 & 1.189 & $2.77 \pm 0.18$ & $12.8 \pm 0.2$ & $2.82 \pm 0.06$ & Whine5 \\
\hline WLL759 & 1.102 & $2.04 \pm 0.18$ & $9.42 \pm 0.15$ & $2.05 \pm 0.05$ & Wai1b \\
\hline WLL760 & 1.285 & $3.29 \pm 0.25$ & $15.2 \pm 0.2$ & $2.08 \pm 0.05$ & Wai10a \\
\hline WLL761 & 1.240 & $3.18 \pm 0.19$ & $12.7 \pm 0.2$ & $1.75 \pm 0.04$ & Wai10b \\
\hline WLL762 & 1.197 & $3.36 \pm 0.18$ & $15.3 \pm 0.2$ & $2.32 \pm 0.05$ & Wai11a \\
\hline WLL763 & 1.229 & $3.15 \pm 0.14$ & $14.5 \pm 0.2$ & $2.22 \pm 0.04$ & Wai11b \\
\hline
\end{tabular}

${ }^{1}$ Ratio wet sample to dry sample weight. Errors assumed $50 \%$ of $(\delta-1)$.

${ }^{2} \mathrm{U}$ and Th-content is calculated from the error weighted mean of the isotope equivalent contents

Table C2-2. Measured a-value, equivalent dose, cosmic and total doserate, and luminescence age

\begin{tabular}{|c|c|c|c|c|c|c|}
\hline Sample no. & a-value & $\mathrm{D}_{\mathrm{e}}(\mathrm{Gy})$ & $\begin{array}{c}\mathrm{dD} / \mathrm{dt} \\
(\mathrm{Gy} / \mathrm{ka})\end{array}$ & $\begin{array}{c}\mathrm{dD}_{\mathrm{T}} / \mathrm{dt} \\
(\mathrm{Gy} / \mathrm{ka})^{\#}\end{array}$ & $\begin{array}{c}\text { OSL- } \\
\text { age (ka) }\end{array}$ & $\begin{array}{c}\text { Field } \\
\text { code }\end{array}$ \\
\hline WLL651 & $0.090 \pm 0.010$ & $182.5 \pm 8.9$ & $0.188 \pm 0.009$ & $5.44 \pm 0.41$ & $33.5 \pm 3.0$ & Whine 1 \\
\hline WLL652 & $0.051 \pm 0.006$ & $71.7 \pm 4.5$ & $0.193 \pm 0.010$ & $4.76 \pm 0.34$ & $15.1 \pm 1.4$ & Whine 2 \\
\hline WLL653 & $0.068 \pm 0.014$ & $47.5 \pm 2.3$ & $0.180 \pm 0.009$ & $4.71 \pm 0.37$ & $10.1 \pm 0.9$ & Whine 4 \\
\hline WLL654 & $0.079 \pm 0.006$ & $98.3 \pm 5.2$ & $0.188 \pm 0.009$ & $4.97 \pm 0.30$ & $19.8 \pm 1.6$ & Whine5 \\
\hline WLL759 & $0.074 \pm 0.009$ & $149.9 \pm 7.3$ & $0.166 \pm 0.008$ & $3.96 \pm 0.17$ & $\begin{array}{c}37.9+- \\
2.4\end{array}$ & Wai1b \\
\hline WLL760 & $0.092 \pm 0.011$ & $63.8 \pm 2.3$ & $0.194 \pm 0.010$ & $4.51 \pm 0.37$ & $\begin{array}{c}14.2+- \\
1.3\end{array}$ & Wai10a \\
\hline WLL761 & $0.078 \pm 0.004$ & $29.2 \pm 1.5$ & $0.198 \pm 0.010$ & $3.97 \pm 0.27$ & $\begin{array}{c}7.4+-0.6 \\
\text { Wai10b }\end{array}$ \\
\hline WLL762 & $0.070 \pm 0.007$ & $93.6 \pm 4.4$ & $0.187 \pm 0.009$ & $4.85 \pm 0.30$ & $\begin{array}{c}19.3+- \\
1.5\end{array}$ & Wai11a \\
\hline WLL763 & $0.059 \pm 0.011$ & $116.5 \pm 4.4$ & $0.193 \pm 0.010$ & $4.34 \pm 0.32$ & $\begin{array}{c}26.8+- \\
2.2 *\end{array}$ & Wai11b \\
\hline
\end{tabular}

${ }^{1}$ Contribution of cosmic radiation to the total doserate, calculated as per Prescott \& Hutton (1994).

\# The doserate dD/dt was calculated using the conversion factors of Adamiec and Aitken (1998)

* This age is considered a maximum age, as the sample failed the plateau test 


\section{C3 Interpretation of modern ${ }^{14} \mathrm{C}$ ages of samples from Terrace $\mathrm{E}$ at Waiohine River}

The ${ }^{14} \mathrm{C}$ ages obtained for wood (Whine 6) and charcoal (Whine 3) collected within the silt coverbed of terrace $\mathrm{E}$, on the upthrown and downthrown sides of the fault, are 0-550 calibrated years B.P. $(2 \sigma)$ and $0-280$ calibrated years B.P. $(2 \sigma)$ (Table 1). These modern ${ }^{14} \mathrm{C}$ ages suggest that the wood sample may be a root, and the charcoal sample collected near the ground surface, may have been deposited during flooding onto terrace E long after its abandonment. The abandonment age of terrace $\mathrm{E}$ is expected to predate the timing of the penultimate earthquake on the Wairarapa Fault, as terrace E records displacement from both the 1855 and penultimate events. 


\section{C4 Previous age estimates for the Waiohine surface}

Table C4-1. Previous age estimates for the Waiohine surface or equivalent aggradation surfaces in the southern North Island (Modified from Grapes, 1991).

\begin{tabular}{|c|c|c|c|}
\hline Year & Author(s) & $\begin{array}{l}\text { Inferred age } \\
\text { of Waiohine } \\
\text { Surface (kyr) }\end{array}$ & Comments \\
\hline 1952 & Te Punga & 3 & $\begin{array}{l}{ }^{14} \mathrm{C} \text { date of log within youngest aggradation terrace, Rangitikei } \\
\text { Basin }\end{array}$ \\
\hline 1955 & Wellman & 10 & $\begin{array}{l}\text { End of Last Glacial and age of youngest aggradation surface } \\
\text { throughout New Zealand }\end{array}$ \\
\hline 1956 & Lensen et al. & 10 & $\begin{array}{l}\text { End of Last Glacial and age of youngest aggradation surface } \\
\text { throughout New Zealand }\end{array}$ \\
\hline 1962 & Cowie \& Wellman & $>10$ & $\begin{array}{l}{ }^{14} \mathrm{C} \text { dated logs of Te Punga (1952) deposited by flash flood. No } \\
\text { loess overlying gravels containing logs where Ohakean Gravel } \\
\text { typically has a foot of loess cover. Age estimated from soil } \\
\text { profiles and loess accumulation rates in Rangitikei Basin }\end{array}$ \\
\hline 1971 & Lensen \& Vella & $\begin{array}{l}\text { a. } 35 \\
\text { b. } 20+\end{array}$ & $\begin{array}{l}\text { Waiohine Surface at Waiohine River. a. Lensen's age represents } \\
\text { second to last stadial of Last Glacial because the Last Stadial } \\
\text { might possibly have only had weak effects in the North Island of } \\
\text { New Zealand } \\
\text { Waiohine Surface at Waiohine River. b. Vella's age represents } \\
\text { the Last Stadial of the Last Glacial because the Waiohine surface } \\
\text { is directly overlain by Holocene deposits around Lake Wairarapa, } \\
\text { it is the youngest extensive aggradation surface and the only one } \\
\text { still extensively preserved in the Waiohine Valley, and it has little } \\
\text { or no cover of loess which is produced in quantity only during } \\
\text { cold-climate phases }\end{array}$ \\
\hline 1972 & Wellman & 11.5 & $\begin{array}{l}\text { Correlation between five dated uplifted beach ridges at Turakirae } \\
\text { Head and five youngest displaced degradation terraces at } \\
\text { Waiohine River. Average rate of uplift, vertical and dextral faulting } \\
\text { assumed to be uniform. Fifth terrace correlated with } 6,300 \text { year } \\
\text { age. Age inferred from vertical offset of Waiohine surface } \\
\text { Correlation between five dated uplifted beach ridges at Turakirae } \\
\text { Head and five youngest displaced degradation terraces at } \\
\text { Waiohine River. Average rate of uplift, vertical and dextral faulting } \\
\text { assumed to be uniform. Fifth terrace correlated with } 6,300 \text { year } \\
\text { age. Age inferred from horizontal offset of Waiohine surface, } \\
\text { estimated from ratio of horizontal to vertical displacement for } \\
\text { terrace B }\end{array}$ \\
\hline 1973 & Suggate \& Lensen & 18 & $\begin{array}{l}\text { Criticism of Wellmans (1972) correlation. Age based on }{ }^{14} \mathrm{C} \text { ages } \\
\text { of "correlative" aggradation surfaces in South Island }\end{array}$ \\
\hline 1973 & Milne & $\begin{array}{l}12-13 \\
13-15\end{array}$ & $\begin{array}{l}\text { Ages of youngest (Ohakean } 3 \text { ) terrace (same surface as dated by } \\
\text { Te Punga and Cowie \& Wellman), and Ohakean } 2 \text { terrace, based } \\
\text { on relative thickness of Ohakean loess on Ohakean terrace and } \\
\text { older surfaces, and } 20 \mathrm{ka} \text { age for Aokautere Ash, Rangitikei } \\
\text { Basin }\end{array}$ \\
\hline 1979 & Milne \& Smalley & $9.5 \pm 0.1$ & $\begin{array}{l}{ }^{14} \mathrm{C} \text { age for top loess that blew from youngest aggradation } \\
\text { surface. Base of loess dated at } 26.3 \pm 0.8 \mathrm{kyr} \text {, Rangitikei Basin }\end{array}$ \\
\hline 1980 & Hubbard \& Neall & $\begin{array}{l}11.8 \pm 0.15 \\
12.15 \pm 0.15\end{array}$ & $\begin{array}{l}{ }^{14} \mathrm{C} \text { age for alluvial fan, West Tamaki River, southern Ruahine } \\
\text { Range } \\
{ }^{14} \mathrm{C} \text { age for alluvial fan, West Tamaki River, southern Ruahine } \\
\text { Range }\end{array}$ \\
\hline 1987 & Tompkins & $8.5 \pm 0.12$ & $\begin{array}{l}{ }^{14} \mathrm{C} \text { age of peaty material near base of peat overlying Waiohine } \\
\text { Surface, south of Greytown (NZ7244, NZ7245, NZ7246, NZ7248 } \\
\text { R/C dates of peat cover yielded ages between 8-10 ka) }\end{array}$ \\
\hline 1988 & $\begin{array}{l}\text { Grapes \& Wellman } \\
\text { (unpub. data) }\end{array}$ & 12.5 & $\begin{array}{l}\text { From available evidence/total data. Climatic and Pollen data } \\
\text { indicate that about this time there was a change from cold and } \\
\text { dry to warm and wet climate and that river erosion increased }\end{array}$ \\
\hline 1990 & Marden \& Neall & $\begin{array}{l}10.35 \pm 0.1 \\
12.65 \pm 0.15 \\
12.9 \pm 0.2\end{array}$ & $\begin{array}{l}{ }^{14} \mathrm{C} \text { age for wood from } 3.5 \text { metres depth below aggradation } \\
\text { surface, near Woodville. Youngest of Ohakean surfaces } \\
{ }^{14} \mathrm{C} \text { age for wood from a few metres below aggradation surface, } 2 \\
\mathrm{~km} \mathrm{NW} \text { of Woodville. Gravels derived from southern Ruahine } \\
\text { Range. Age for younger of } 2 \text { terraces of Ohakean age } \\
{ }^{14} \mathrm{C} \text { age for wood from a few metres below aggradation surface, } 2 \\
\mathrm{~km} \mathrm{NW} \text { of Woodville. Gravels derived from southern Ruahine } \\
\text { Range. Age for younger of } 2 \text { terraces of Ohakean age }\end{array}$ \\
\hline 1990 & Suggate & 16 & $\begin{array}{l}\text { Age inferred from constant rate of loess accumulation from } 35.5 \\
\mathrm{kyr} \text { with respect to position of kawakawa tephra layer dated at } \\
22.5 \mathrm{kyr}\end{array}$ \\
\hline 1991 & Grapes & $11 \pm 1$ & Based on available evidence? \\
\hline 1993 & Grapes \& Wellman & $\begin{array}{l}12.76 \pm 0.11 \\
12.45 \pm 0.12\end{array}$ & $\begin{array}{l}\text { Tree roots in upper part of inferred Ohakean loess at Palliser bay } \\
\text { Tree roots in upper part of inferred Ohakean loess at Palliser bay }\end{array}$ \\
\hline
\end{tabular}




\begin{tabular}{|c|c|c|c|}
\hline & & $12.44 \pm 0.10$ & Tree roots in upper part of inferred Ohakean loess at Palliser bay \\
\hline 1994 & $\begin{array}{l}\text { Pillans; Pillans et } \\
\text { al., (1993) }\end{array}$ & $\begin{array}{l}10 \\
12\end{array}$ & $\begin{array}{l}\text { Ages for Ohakea (3) and (2), based on ages adopted by Milne, } \\
1973 \text {, and } 14 C \text { ages reported by Milne \& Smalley, 1979, and } \\
\text { Marden \& Neall, } 1990\end{array}$ \\
\hline 2000 & Lian et al., & $\begin{array}{l}26 \pm 3 \\
22 \pm 2\end{array}$ & $\begin{array}{l}\text { Ohakean loess overlying moa skeleton in Tauweru Valley, } \\
\text { eastern Wairarapa } \\
\text { Ohakean loess overlying moa skeleton in Tauweru Valley, } \\
\text { eastern Wairarapa }\end{array}$ \\
\hline 2001 & Wang & $\begin{array}{l}10.4 \pm 0.6 \\
5.0 \pm 0.4\end{array}$ & $\begin{array}{l}\text { OH-1 Loess from Ohakean terrace, } 0.25 \text { metres above top of } \\
\text { Ohakean gravels, } 1.47 \text { metres below top of terrace, south of Bulls } \\
\text { WK-1 Loess from } 0.6 \text { metres below extensive aggradation } \\
\text { surface (Waiohine?), } 0.1 \text { metres above gravels, Wharekauhau } \\
\text { Stream, Palliser Bay }\end{array}$ \\
\hline 2002 & $\begin{array}{l}\text { Formento-Trigilio et } \\
\text { al., }\end{array}$ & $\begin{array}{l}7.95 \pm 0.65 \\
10.4 \pm 1.1 \\
10.5 \pm 1.2 \\
5.12 \pm 0.37\end{array}$ & $\begin{array}{l}\text { Loess from most extensive Waiohine terrace tread in Huangarua } \\
\text { River Valley, correlated to youngest of Milne's (1973) Ohakean } \\
\text { terraces } \\
\text { Loess from most extensive Waiohine terrace tread in Huangarua } \\
\text { River Valley, correlated to youngest of Milne's (1973) Ohakean } \\
\text { terraces } \\
\text { Loess from most extensive Waiohine terrace tread in Huangarua } \\
\text { River Valley, correlated to youngest of Milne's (1973) Ohakean } \\
\text { terraces } \\
\text { Loess from most extensive Waiohine terrace tread in Huangarua } \\
\text { River Valley, correlated to youngest of Milne's (1973) Ohakean } \\
\text { terraces }\end{array}$ \\
\hline 2005 & 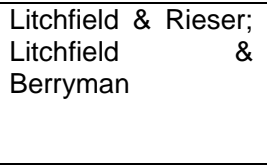 & $\begin{array}{l}11.3 \pm 0.8 \\
13.2 \pm 0.9\end{array}$ & $\begin{array}{l}\text { Minimum age for most widespread aggradation terrace, north } \\
\text { eastern North Island } \\
\text { Minimum age for most widespread aggradation terrace, north } \\
\text { eastern North Island }\end{array}$ \\
\hline 2007 & $\begin{array}{l}\text { Wang \& Grapes; } \\
\text { Wang (2001) }\end{array}$ & $\begin{array}{l}13.0 \pm 9.0 \\
10.2 \pm 1.2 \\
10.0 \pm 0.8 \\
16.1 \pm 1.6 \\
14.7 \pm 0.8 \\
10.8 \pm 1.4 \\
10.6 \pm 0.9 \\
14.8 \pm 1.1\end{array}$ & $\begin{array}{l}\text { Wh-1 Gravelly silt overlying Waiohine surface at Waiohine River } \\
\text { Wh-2 Gravelly silt overlying Waiohine surface at Waiohine River } \\
\text { MR-1 Overbank silt/loess on Waiohine surface, Matarawa Road, } \\
\text { Waiohine River. Youngest age for Waiohine surface } \\
\text { Tw-2 Silt within Waiohine surface at Tauwharenikau River. Oldest } \\
\text { age for Waiohine surface } \\
\text { Tw-3 Silt overlying Waiohine surface at Tauwharenikau River } \\
\text { PB-3 Loess overlying Waiohine surface at Pigeon Bush } \\
\text { Bt-1 Older Ohakean and Rata loess eroded while youngest } \\
\text { Ohakean loess deposited on Porewan surface, Waingawa River } \\
\text { Bt-2 Loess from stream channel incised into Rata surface, } 0.8 \\
\text { metres above Kawakawa tephra which is } 0.7 \text { metres above the } \\
\text { gravel surface. Based on } 0.7 \text { mm/yr rate of accumulation, top of } \\
\text { loess could be } 11 \text { kyrs } \\
\text { PB-1 Redeposited material forming upper part of small fan at } \\
\text { Pigeon Bush, minimum age for Waiohine Surface } \\
\text { PB-2 Silt deposited by stream incised into post-Waiohine surface } \\
\text { fan } \\
\text { Tw-1 Silt matrix of greywacke cobbles near edge of sag at } \\
\text { Wairarapa Fault, seismically disturbed } \\
\text { Summary: Age range for Waiohine surface } 16.4 \pm 1.2 \text { ka to } 10.0 \\
\pm 0.9 \text { ka }\end{array}$ \\
\hline 2009 & Little et al., & $12.4 \pm 0.3$ & $\begin{array}{l}{ }^{14} \mathrm{C} \text { age for peat layer, } 2.33 \mathrm{~m} \text { depth, interbedded with coarse } \\
\text { fluvial gravels of the Waiohine terrace, in uplifted block of fault } \\
\text { zone, on southern strand of Wairarapa Fault at Cross Creek } \\
\text { graben }\end{array}$ \\
\hline
\end{tabular}


D Applicability of Analogue Models to Surface Deformation along the Wairarapa Fault 


\section{D1 Applicability of analogue models to surface deformation along the Wairarapa Fault}

We compare our observations of surface deformation along the Wairarapa Fault with the previously cited results of analogue models from each of the four main categories described in Section 3.6.1, as a function of different boundary conditions. We describe the differences between the model boundary conditions and the actual Wairarapa Fault, and assess which models may best describe the observed pattern of surface faulting and deformational bulging along the fault.

\section{Deformation of a non-cohesive overburden above a single strike-slip to oblique-slip basement fault}

The boundary conditions for analogue models of a previously unfaulted sand overburden above a strike-slip to slightly oblique-slip basement fault (e.g. Naylor et al., 1986; Richard, 1991; Richard et al., 1995) are comparable to the boundary conditions at the Wairarapa Fault at two scales (scale of Type A and Type B faults). The upward propagation of this young branch of the Wairarapa Fault implies that the previously unfaulted upper crust above this splay was once analogous to the initially unfaulted overburden above the basement fault discontinuity in the analogue models (section 3.6.1), and that these models can be applied to the formation of the Type A faults within the basement rock (inferred from calculated fault convergence depths well below the Waiohine gravels, section 3.7.2) above a newly formed branch of the Wairarapa Fault. These models imply a discontinuity between the base-plate and the non-cohesive overburden that must become coincident with the point of convergence of newly developed faults in the overburden into the basement fault discontinuity. Such a discontinuity is unknown at the depth of Type A fault convergence along the Wairarapa Fault. A stratigraphic discontinuity exists between overlapping Waiohine gravels and the much older and presumably more strongly faulted Cenozoic/Mesozoic basement, at $\sim 30 \mathrm{~m}$ depth. Our volume calculations suggest that this relatively young discontinuity at the base of the Waiohine gravels may coincide with the depth at which Type B overburden faults converge into the single Type A fault segment to which they belong. These models are therefore most applicable to the formation of Type B fault segments above a pre-exiting (Type A) basement fault discontinuity along the Wairarapa Fault. The $\sim 230^{\circ}$ azimuth of slip at the Wairarapa Fault implies a convergence angle oriented $\sim 3^{\circ}$ clockwise to the average strike of the Wairarapa Fault (Figure 17). The reverse-oblique strike-slip model of Richard et al., (1995) implies that the fault pattern 
generated for fault convergence angles as high as $\sim 7^{\circ}$ on a $45^{\circ}$ dipping basement fault (section 3.6.2) strongly resemble those generated by pure strike-slip models, making both pure strike-slip and slightly-oblique slip models applicable to the natural case of the Wairarapa Fault.

The surface fault geometry at the Wairarapa Fault resembles that predicted by the analogue models (e.g. Naylor et al., 1986; Richard, 1991; Richard et al., 1995). Similar to the early stage of fault evolution of all the analogue models, the Wairarapa Fault exhibits a series of discontinuous en echelon Type A fault segments (R-faults), separated by large stepovers with moderate overlap (Figure 18). Within these Type A fault segments, a series of shorter Type B faults are arranged en echelon to the Type B fault segment to which they belong (Plates 112). The en echelon faults segments (R-faults) observed along the Wairarapa Fault are scissor faults with a sense of vertical displacement that switches across the trace of the basement fault. On the Wairarapa Fault, the R-faults display an across-strike asymmetry and partitioning of slip where they bound deformational bulges, similar to the predictions of modelling by Richard et al., (1995) for deformation above a dipping reverse-oblique strikeslip fault.

The Wairarapa Fault displays small splay faults, 30-200 $\mathrm{m}$ in length, that branch off the northwest side of the Type B fault (R-fault) segments, above the upthrown side of the basement fault (Plates 2-4). These splay faults strike at a higher clockwise angle to the average strike of the fault than the R-faults, another feature that is predicted by some of the analogue models. Short-lived splay faults generally branch from or near the tips of R-faults in strike-slip analogue models, however, along the Wairarapa Fault, the observed splay faults branch northwest from the centre of the Type B faults (R-faults), not at/near their tips. In strike-slip analogue models, P-faults are predicted to develop in the stepover region between adjacent $\mathrm{R}$-faults, striking at the same angle to the basement fault as the R-faults, but in the opposite direction. At Type $\mathrm{C}$ bulges along the Wairarapa Fault, the adjacent en echelon Type B faults almost completely overlap forming enclosed shear lenses, between which, faults resembling low-angle R faults and P-faults have developed (Figures 22d \& m), as is predicted for a later stage of fault evolution by the analogue models (e.g. Naylor et al., 1986). The Type C bulge just north of Tauwharenikau River (Figure 22d) exhibits the exact same geometry as a fully formed shear lense in the final stage of fault evolution in Naylor et al.,'s (1986) analogue model (Figure 2 of Naylor et al., 1986). 
Two important differences are identified between the surface fault geometry at the Wairarapa Fault and that predicted by the analogue models of Naylor et al., (1986) and Richard et al., (1991). Type A and B faults strike at a lower angle $\left(2^{\circ}-11^{\circ}\right.$, average of $\sim 6^{\circ}$ $7^{\circ}$ ) to the average strike of the higher order fault to which they belong, than the $17^{\circ}-20^{\circ}$ predicted by analogue models for R-fault formation above strike-slip to slightly oblique-slip faults (for densely packed sand according to ideal Coulomb-Mohr behaviour). The Wairarapa Fault also forms a very narrow $(<350 \mathrm{~m})$ fault zone, made up of long en echelon Type A fault segments, in comparison to the wider $(1-2 \mathrm{~km})$ fault zone made up of numerous shorter faults that is predicted by strike-slip analogue models (e.g. Naylor et al., 1986; Richard et al., 1995).

\section{Distributed deformation of a brittle upper layer overlying a viscous lower layer}

The boundary conditions for analogue models of distributed deformation of a sand pack overlying a viscous medium (e.g. Casas et al., 2001; Schreurs, 2003: Schreurs \& Colletta, 1998) are very different to the boundary conditions at the Wairarapa Fault. The sandpack can be thought of as being analogous to the brittle upper crust, and the viscous material as the ductilely deforming middle to lower crust (at the crustal scale), or a weak sedimentary later consisting of salt, evaporates or overpressured shales (on the basin scale). At the Wairarapa Fault there is no evidence for a viscous material at $\sim 200 \mathrm{~m}$ depth where the fault becomes contiguous, as is predicted by these models. Despite this difference, the pattern of surface deformation in distributed deformation models is very similar to those previously described for models of a basement strike-slip fault in the early stages of fault evolution (refer to section 3.6.1 and previous section on deformation above a strike-slip to obliqueslip basement fault).

\section{Deformation of a non-cohesive overburden above a rigid restraining bend in the}

\section{basement fault}

Analogue models of deformation of a non-cohesive sandpack overlying a restraining bend (e.g. McClay \& Bonora, 2001; Richard et al., 1995) may have similar boundary conditions to parts of the Wairarapa Fault. In these models, there is again a discontinuity between the previously undeformed non-cohesive overburden and the cohesive baseplate in which the basement fault bend exists. At the Wairarapa Fault a stratigraphic discontinuity exists between the previously undeformed, rapidly deposited Waiohine gravels and the underlying Cenozoic/Mesozoic basement. Our calculated fault convergence depth for Type A faults along the Wairarapa fault is much deeper than the thickness of the Waiohine gravels. From this, we infer that the surface of the basement rock exhibits a similar en echelon fault 
segmentation to that observed for Type A faults at the surface. However, the Wairarapa Fault is discontinuous and highly segmented by fault stepovers, whereas the basement faults in analogue models of fault bends are continuous, bent and through-going. Our calculated fault convergence depth for Type B faults is inferred to coincide with the stratigraphic discontinuity between the Waiohine gravels and the underlying basement rock, implying that the surface of the basement rock does not exhibit the en echelon fault segmentation observed for Type B faults along the Wairarapa Fault, and that these basement fault bend models are not applicable to the Type B bulges. Displacement in these models is purely strike-slip, whereas the Wairarapa Fault exhibits a small component of reverse-oblique slip. The Type A bulges observed along the Wairarapa Fault most closely resemble those formed in the models above a neutral $\left(90^{\circ}\right)$ or underlapping $\left(30^{\circ}\right)$ bend for a moderate to large spacing between adjacent fault segments (Figures 17a, b, d \& e of McClay \& Bonora, 2001; Figure 18b of Richard et al., 1995), where the segments in the case of the Wairarapa Fault are the en echelon Type A fault (R-fault) segments.

Based on a general lack in resemblance to the analogue models, basement fault bends appear an unlikely mechanism for the formation of the observed Type A pressure bulges along the Wairarapa Fault. Some similarities between nature and the models are identified. As is illustrated by the models (particularly a $90^{\circ}$ bend model), the large Type A pressure bulges along the Wairarapa Fault (e.g. Figures 22a \& h) exhibit curved reverse-oblique strike-slip faults above or just outside of the basement fault trace, and rents or faults that cross-cut the central uplifted region at an antithetic fault orientation. At some bulges a pair of outer reverse faults can be observed (e.g. Figure 22h). In general, however, the observed Type A bulges along the Wairarapa Fault are quite different to the predictions of the existing published models. The natural bulges are generally not very dissected by crosscutting faulting linking the offset surface traces of the basement fault bend, and do not display an inner pair of reverse faults within the bulge. The Type A bulges display much greater asymmetry in the distribution of strike-slip and dip-slip displacements across their bounding fault strands than illustrated by the pure-strike-slip deformational fault bend models. The natural bulges also differ significantly in shape from those predicted by the models, appearing quite triangular with sharp pointing tips and broad rounded bases. At the Wairarapa Fault, bulges are located mostly on the upthrown basement fault block, rather than being distributed evenly across both sides of the basement fault as in most of the analogue models. 


\section{Development of wrench folds in the overburden above a strike-slip basement fault}

Analogue models of the development of wrench folds in a wax or clay overburden above a basement strike-slip fault discontinuity (e.g. Odonne \& Vialon, 1983; Wilcox et al., 1973) have comparable boundary conditions to the Wairarapa Fault. For Type A bulges, the strike-slip fault at the base of these models might be analogous to the single Wairarapa Fault plane as it exists in Cenozoic/Mesozoic basement, whereas the wax or clay overburden might be analogous to some combination of Late Cenozoic sedimentary rocks and the young Waiohine aggradation gravels. For Type B bulges, the strike-slip fault at the base of these models might be analogous to the Type A faults that exist at the surface of the basement rock, whereas the overburden might be analogous to the recently deposited Waiohine gravels. A boundary condition of these analogue models is the discontinuity between the baseplate containing the fault, and the overburden material. For Type B bulges, this discontinuity is analogous to the stratigraphic discontinuity at the base of the Waiohine gravels. However, for Type B bulges, such a stratigraphic boundary is unknown. Displacement in these models is purely strike-slip, whereas the Wairarapa Fault exhibits a small component of reverse-oblique slip.

Pressure bulges along the Wairarapa Fault do not appear to have formed as wrench folds. The axes of pressure bulges along the Wairarapa Fault are oriented at low angles (both clockwise and anticlockwise) to the average strike of the fault. If the bulges had formed as classic wrench folds with an initial orientation at $\sim 45^{\circ}$ to the fault, then their present orientation suggests they have undergone a large amount of rotation, as a result of considerable slip on the Wairarapa Fault (e.g. Jamison, 1991; Odonne \& Vialon, 1983; Wilcox et al., 1973). Folds that have undergone a large amount of rotation would be expected to be dissected by faults, which is also not evident at bulges along the Wairarapa Fault. 


\section{References cited in Appendices}

Adamiec, G. and Aitken, M. J. 1998. Dose-rate conversion factors: update. Ancient TL, v. 16, p. 37-50.

Casas, A. M., Gapais, D., Nalpas, T., Besnard, K., and Roman-Berdiel, T. 2001. Analogue models of transpressive systems: Journal of Structural Geology, v. 23, p. 733-743.

Cowie, J. D., and Wellman, H. W. 1962. Age of Ohakea Terrace, Rangitikei River: New Zealand Journal of Geology and Geophysics, v. 5, p. 617-619.

Formento-Trigilio, M. L., Burbank, D. W., Nicol, A., Shulmeister, J., and Rierser, U. 2002. River response to an active fold-and-thrust belt in a convergent margin setting, North Island, New Zealand: geomorphology, v. 49, p. 125-152.

Grapes, R. H. 1991. Aggradation surfaces and implications for displacement rates along the Wairarapa Fault, southern North Island, New Zealand: Catena, v. 18, p. 453-469.

Grapes, R. H., and Wellman, H. W. 1988. The Wairarapa Fault: Victoria University of Wellington Geology Board of Studies, v. 4, p. 54.

Grapes, R. H., and Wellman, H. W. 1993. Field guide to the Wharekauhau Thrust (Palliser Bay) and Wairarapa Fault (Pigeon Bush). Geological Society of New Zealand Miscellaneous Publication, v. 79B, p. 27-44.

Hubbard, C. B., and Neall, V. E. 1980. A reconstruction of late Quaternary erosional events in the West Tamaki River catchment, southern Ruahine Range, North Island, New Zealand: New Zealand Journal of Geology and Geophysics, v 23, p. 587-593.

Jamison, W. R. 1991. Kinematics of compressional fold development in convergent wrench terranes: tectonophysics, v. 190, p. 209-232.

Lensen, G. J., Stevens, G. R., and Wellman, H. W. 1956. The earthquake risk in the Wellington district: New Zealand Science Review, v. 14, p. 131-135.

Lensen, G. J., and Vella, P. 1971. The Waiohine River Faulted Terrace Sequence in Recent Crustal Movements: Royal Society of New Zealand Bulletin, v. 9, p. 117-119.

Lian, O. B., Wang, N., Grapes, R., and Collen, J. 2000. Optical dating of sediments associated with a fossil moa skeleton near Tauweru, Wairarapa, New Zealand: New Zealand Journal of Geology and Geophysics, vol. 43, p. 493-499.

Litchfield, N., and Berryman, K. R. 2005. Correlation of fluvial terraces within the Hikurangi Margin, New Zealand: Implications for climate and base level controls: Geomorphology, v. 68, p. 291-313.

Litchfield, N., and Rieser, U. 2005. Optically stimulated luminescence age constraints for fluvial aggradation terraces and loess in the eastern North Island, New Zealand: New Zealand Journal of Geology and Geophysics, v. 48, p. 581-589.

Little, T. A., Van Dissen, R., Schermer, E., and Carne, R. 2009. Late Holocene surface ruptures on the southern Wairarapa Fault, New Zealand: Link between obliquereverse earthquakes and the raising of beach ridges on a rocky coast: Lithosphere, v. 1, no. 1, p. 4-28.

McClay, K., and Bonora, M. 2001. Analog models of restraining stepovers in strike-slip fault systems. American Association of Petroleum Geologists Bulletin, v. 85, no. 2, p. 233-260.

Marden, M., and Neal, V. E. 1990. Dated Ohakean terraces offset by the Wellington Fault near Woodville, New Zealand: New Zealand Journal of Geology and Geophysics, v. 33, p. 449-453.

Milne, J.D. 1973. Upper Quaternary geology of the Rangitikei drainage basin. PhD Dissertation, Victoria University of Wellington, New Zealand.

Milne, J. D. G., and Smalley, I. J. 1979. Loess deposits in the southern part of the North Island of New Zealand: an outline stratigraphy. Acta Geologica Academiae Scientiarum Hungaricae v. 22, p. 197-204. 
Naylor, M. A., Mandl, G., and Sijpesteijn, C. H. K. 1986. Fault geometries in basementinduced wrench faulting under different initial stress states. Journal of Structural Geology, v. 8, no. 7, p. 737-752.

Odonne, F., and Vialon, P. 1983. Analogue Models of Folds above a Wrench Fault: Tectonophysics, v. 99, p. 31-46.

Pillans, B. 1994. Direct marine-terrestrial correlations, Wanganui Basin, New Zealand: The last 1 million years. Quaternary Science Reviews, v. 13, p. 189-200.

Pillans, B., McGlone, M., Palmer, A., Mildenhall, D., Alloway, B., and Berger, G. 1993. The Last Glacial Maximum in central and southern North Island, New Zealand: a paleoenvironmental reconstruction using the Kawakawa Tephra Formation as a chronostratigraphic marker: Palaeogeography, Palaeoclimatology, Palaeoecology, v. 101, p. 283-304.

Prescott, J. R., and J. T. Hutton (1994), Cosmic ray contributions to dose rates for luminescence and ESR dating: large depths and long-term time variations, Radiation Measurements, 23, 497-500.

Richard, P. 1991. Experiments on faulting in a two-layer cover sequence overlying a reactivated basement fault with oblique-slip. Journal of Structural Geology, v. 13, no. 4, p. 459-469.

Richard, P. D., Naylor, M. A., and Koopman, A. 1995. Experimental models of strike-slip tectonics. Petroleum Geoscience, v. 1, p. 71-80.

Schreurs, G. 2003. Fault development and interaction in distributed strike-slip shear zones: an experimental approach. From: Storti, F., Holdsworth, R. E., and Salvini, F. (eds) Intraplate Strike-Slip Deofrmation Belts. Geological Society, London, Special Publications, v. 210, p. 35-52.

Schreurs, G., and Colletta, B. 1998. Analogue modelling of faulting in zones of continental transpression and transtension. From: Holdsworth, R. E., Strachan, R. A., and Dewey, J. F. (eds) Continental Transpressional and Transtensional Tectonics. Geological Society, London, Special Publications, v. 135, p. 59-79.

Suggate, R. P. 1990. Kawakawa tephra and Ohakea loess. Geological Society of New Zealand Newsletter, v. 88, p. 36-37.

Suggate, R. P., and Lensen, G. J. 1973. Rate of Horizontal Fault Displacement in New Zealand: Nature, v. 242, p. 518.

Te Punga, M. T. 1952. Radiocarbon dating of a Rangitikei River terrace. New Zealand Journal of Science and Technology, v. B35, p. 45-48.

Tompkins, J., 1987, Late Quaternary pollen stratigraphy, geology, and soils of an area south of Greytown, Wairarapa, New Zealand: Geological Society of New Zealand Newsletter, v. 77 , p. 56.

Wang, N. 2001. Optically stimulated luminescence dating techniques and Application to Late Quaternary loess in southern North Island, New Zealand [M. Sc. thesis]: Victoria University of Wellington, 131 p.

Wang, N., and Grapes, R. 2007. Infrared-stimulated luminescence dating of late Quaternary aggradation surfaces and their deformation along an active fault, southern North Island of New Zealand: Geomorphology, v. doi:10.1016/j.geomorph.2007.07.016.

Wellman, H. W. 1955. New Zealand Quaternary Tectonics. Geologische Rundschau, v. 43, p. $248-257$.

Wellman, H. W. 1972. Rate of Horizontal Fault Displacement in New Zealand: Nature, v. 237, p. 275-277.

Wilcox, R. E., Harding, T. P., and Seely, D. R. 1973. Basic Wrench Tectonics: AAPG Bulletin, v. 57, p. 74-96. 


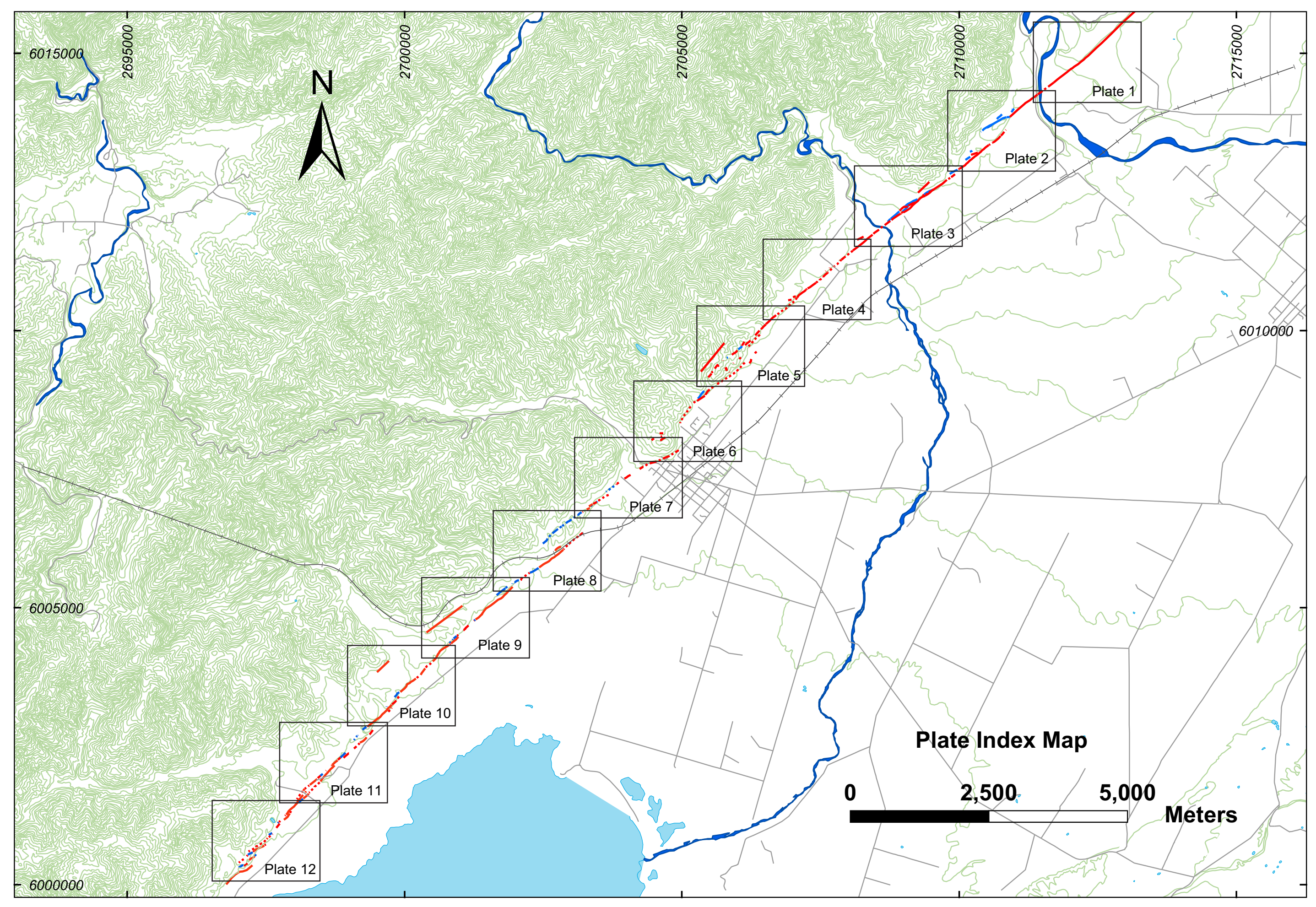




\section{Plate Key}

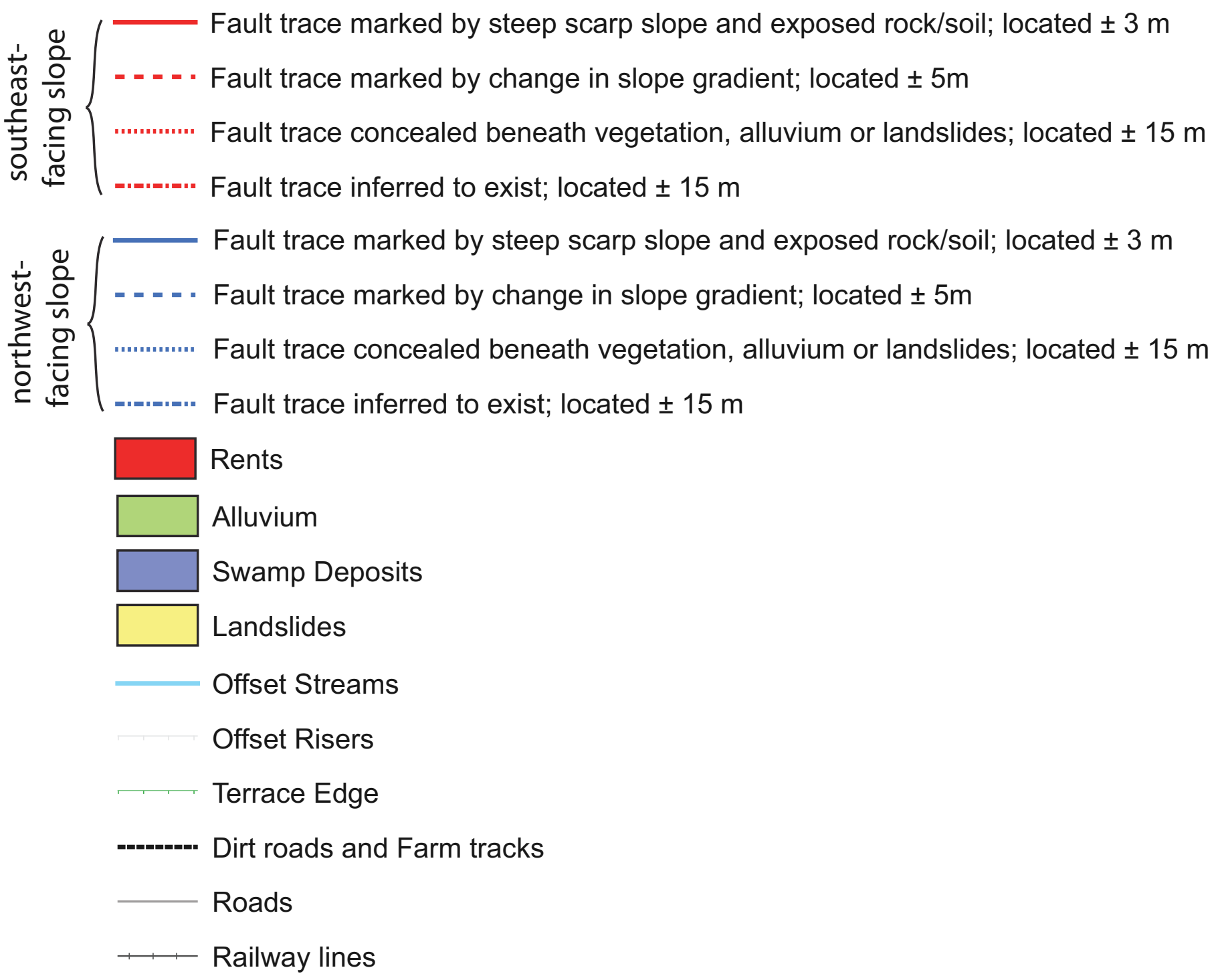




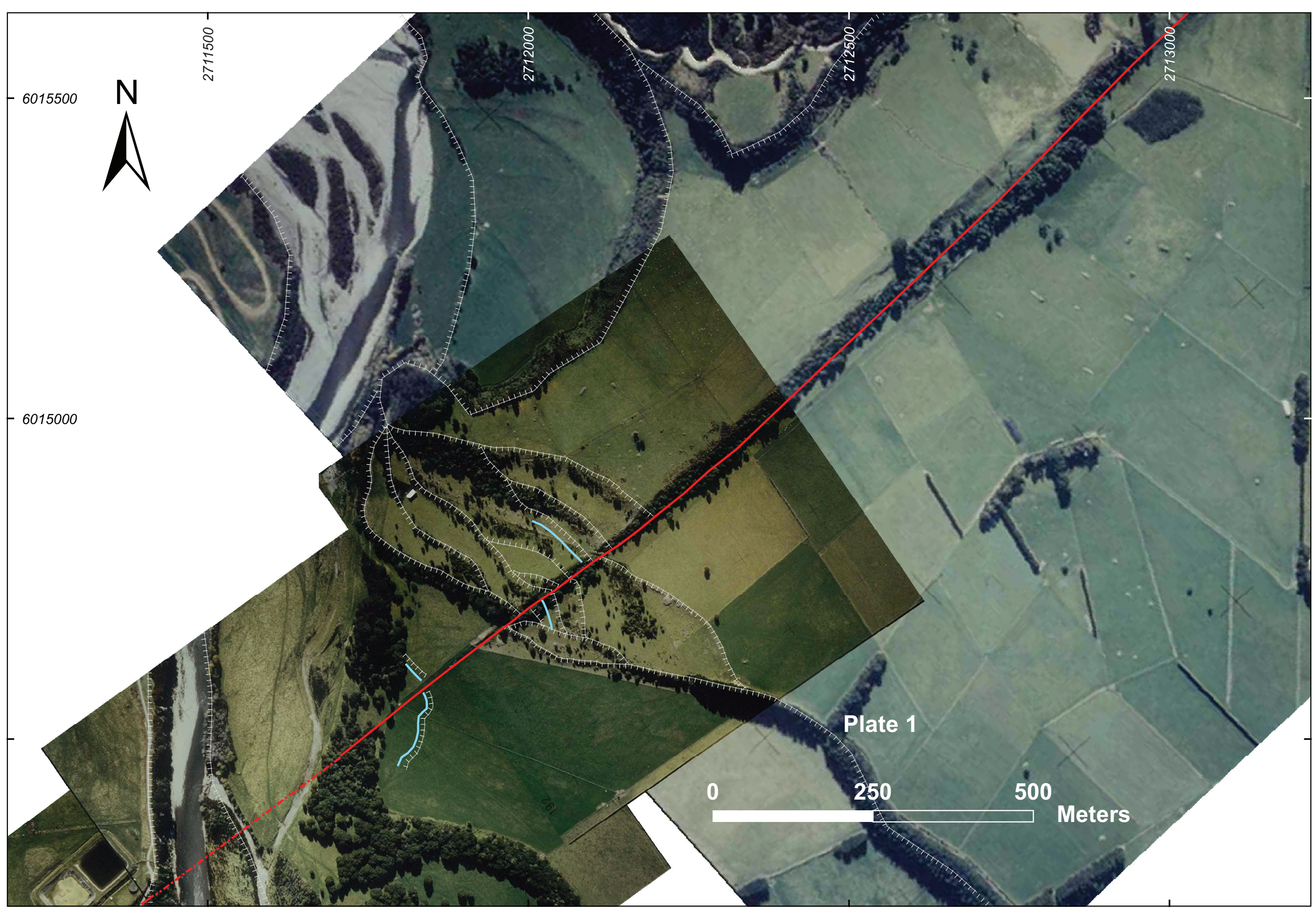




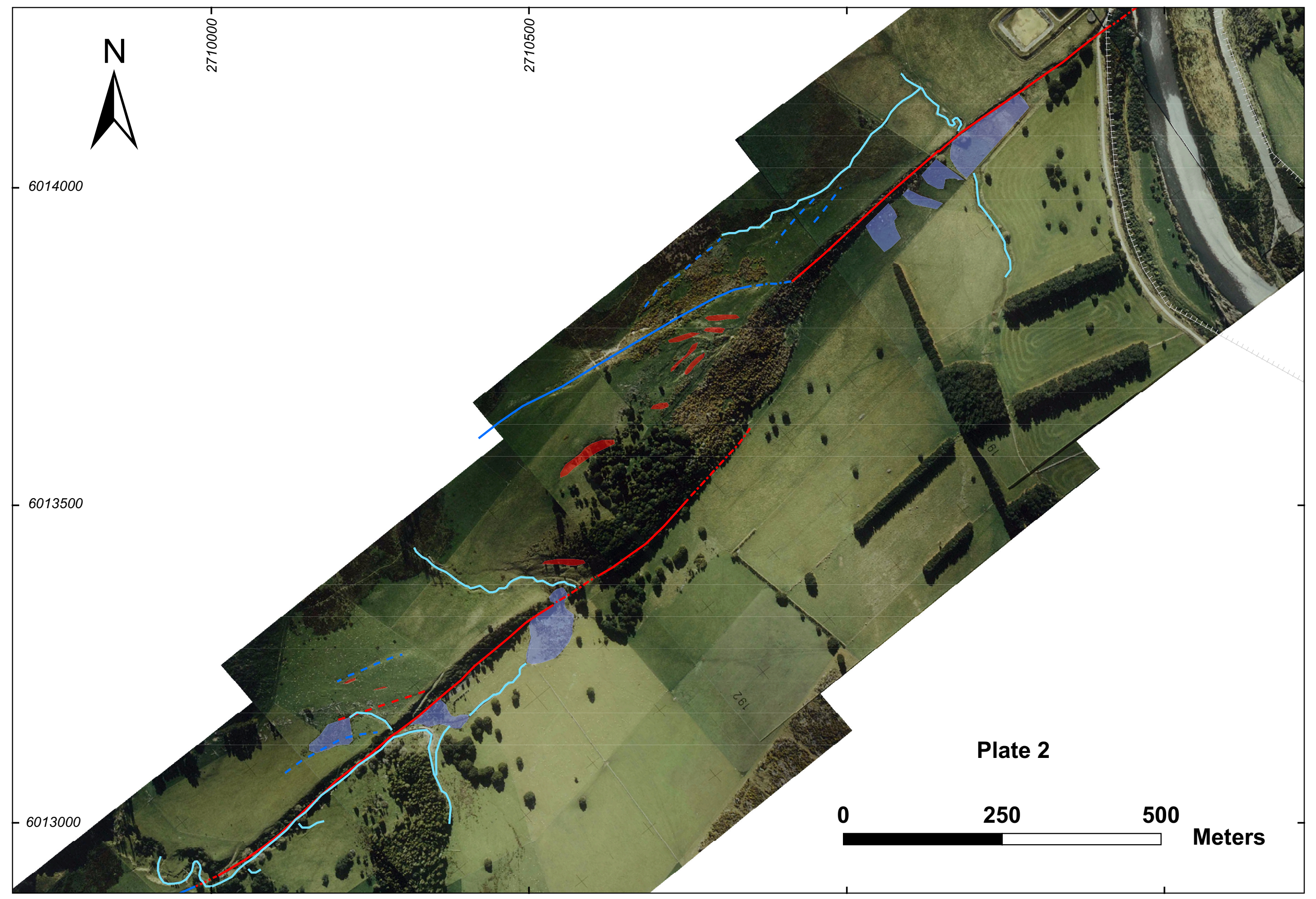




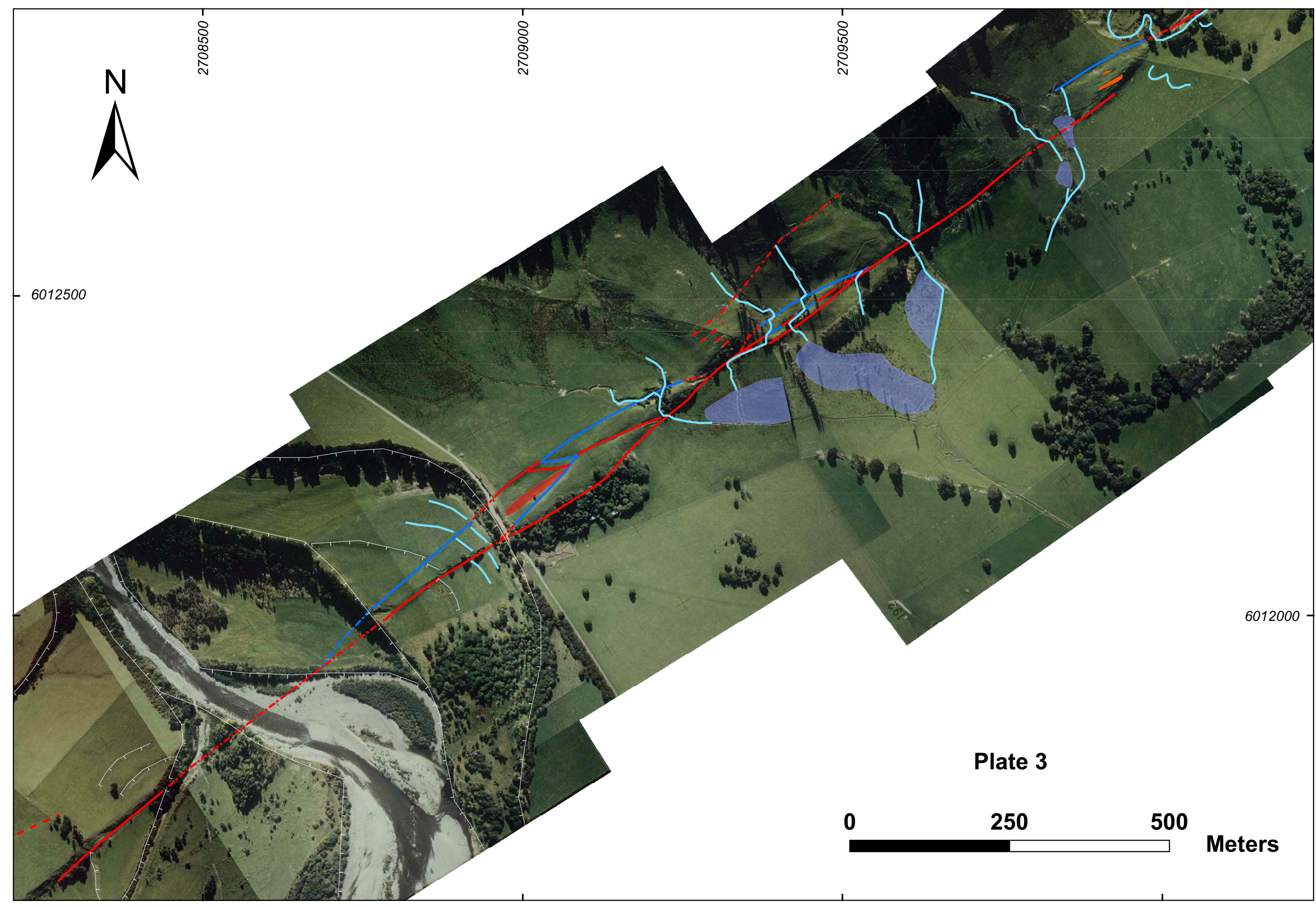




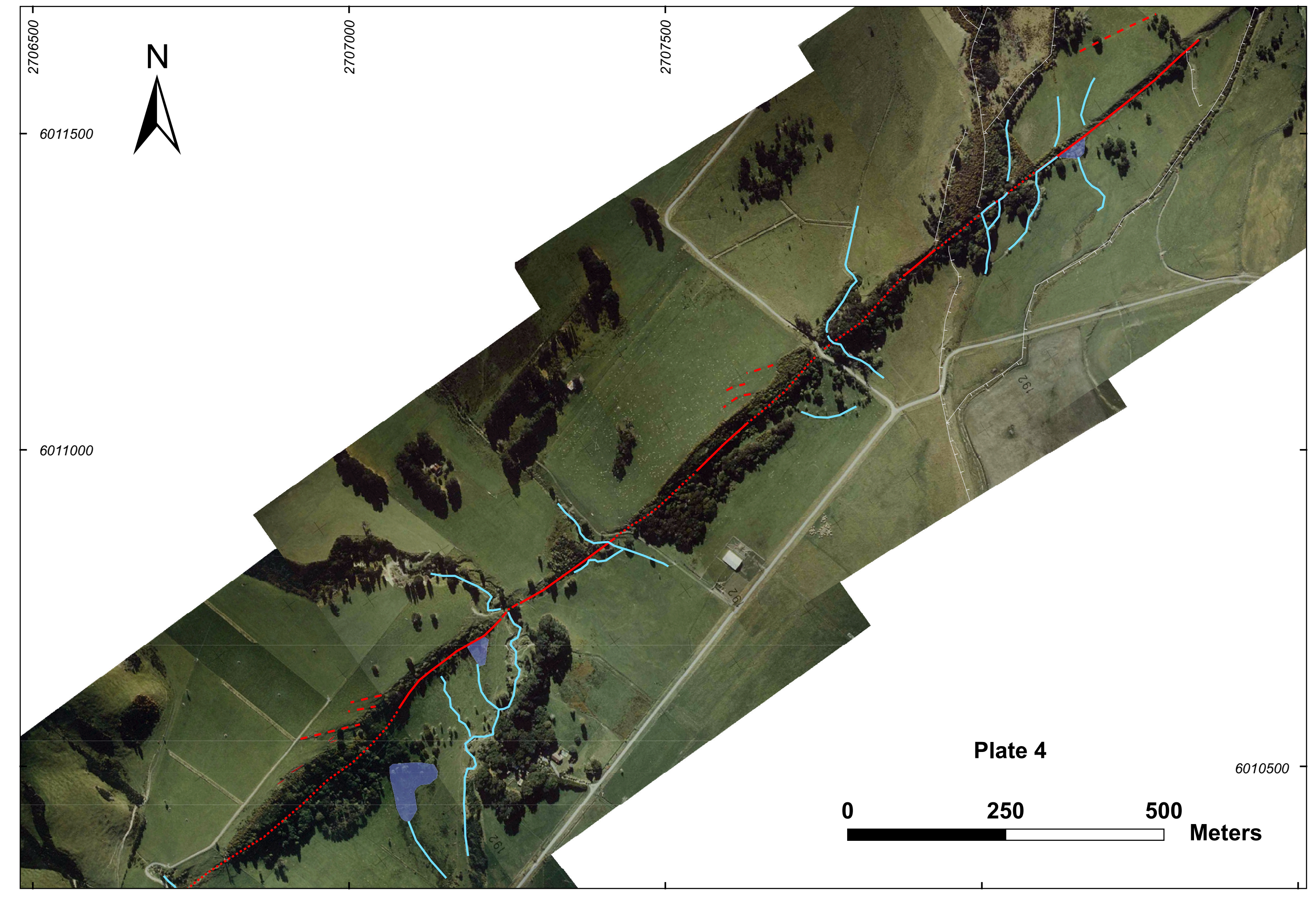




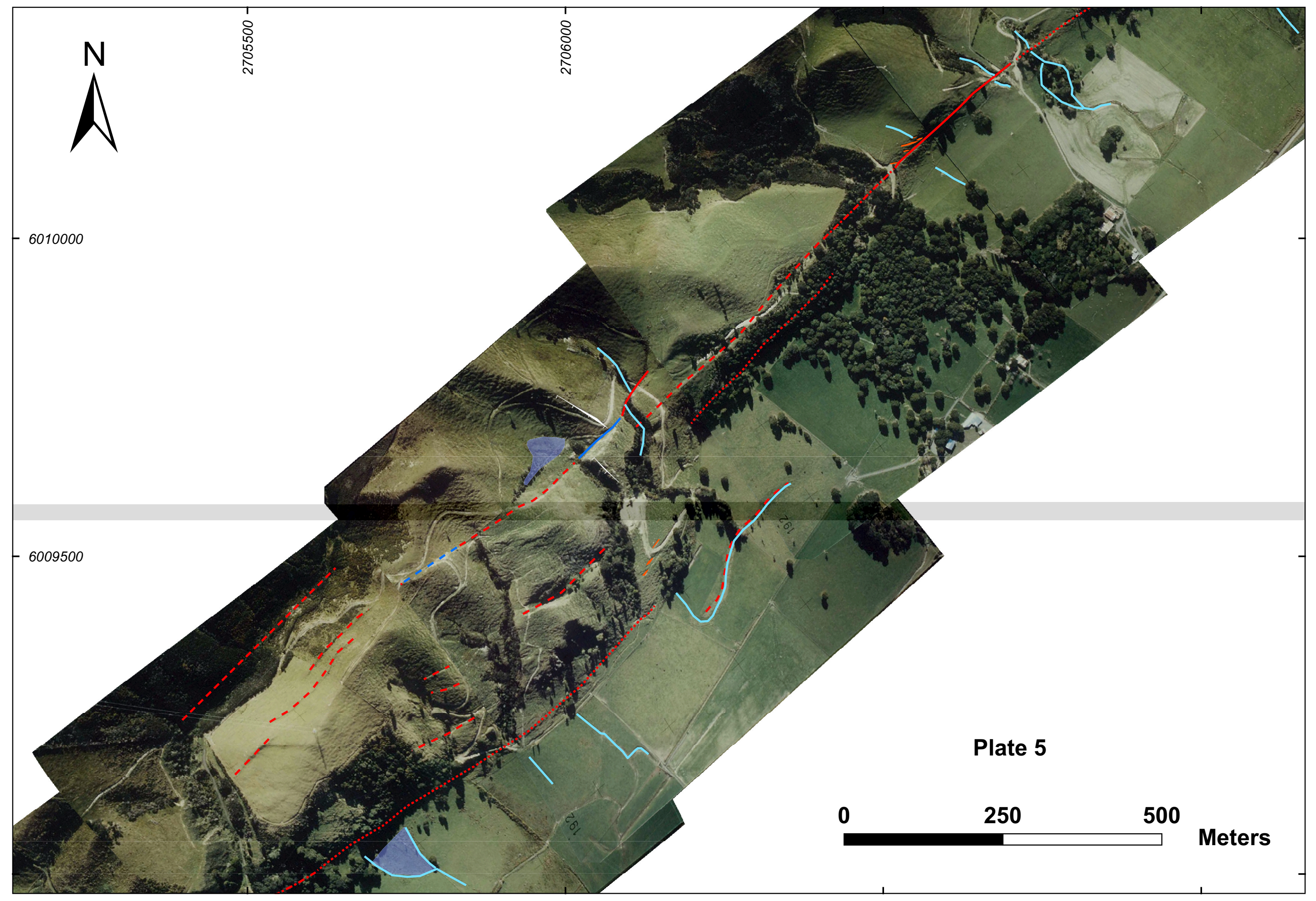




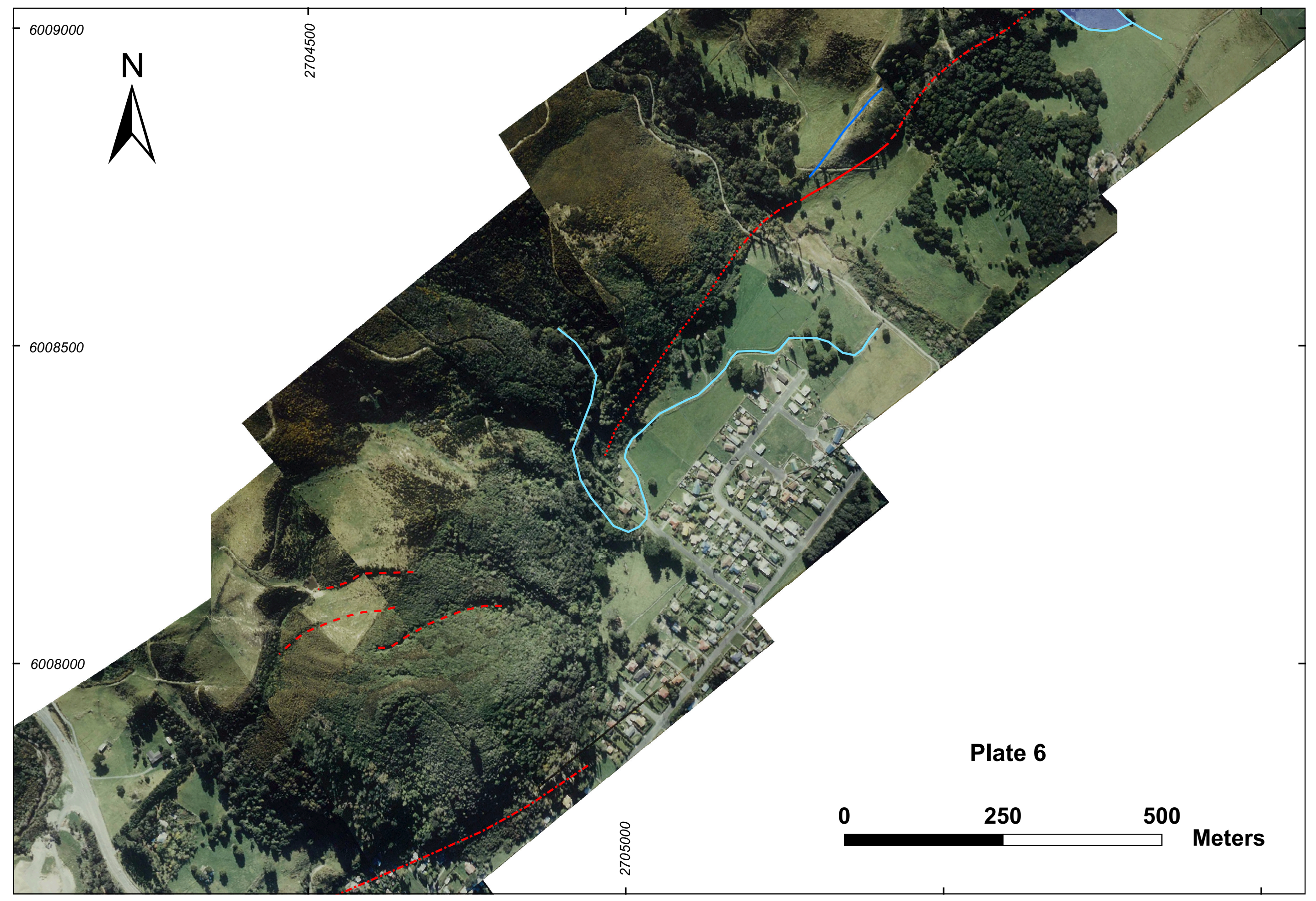




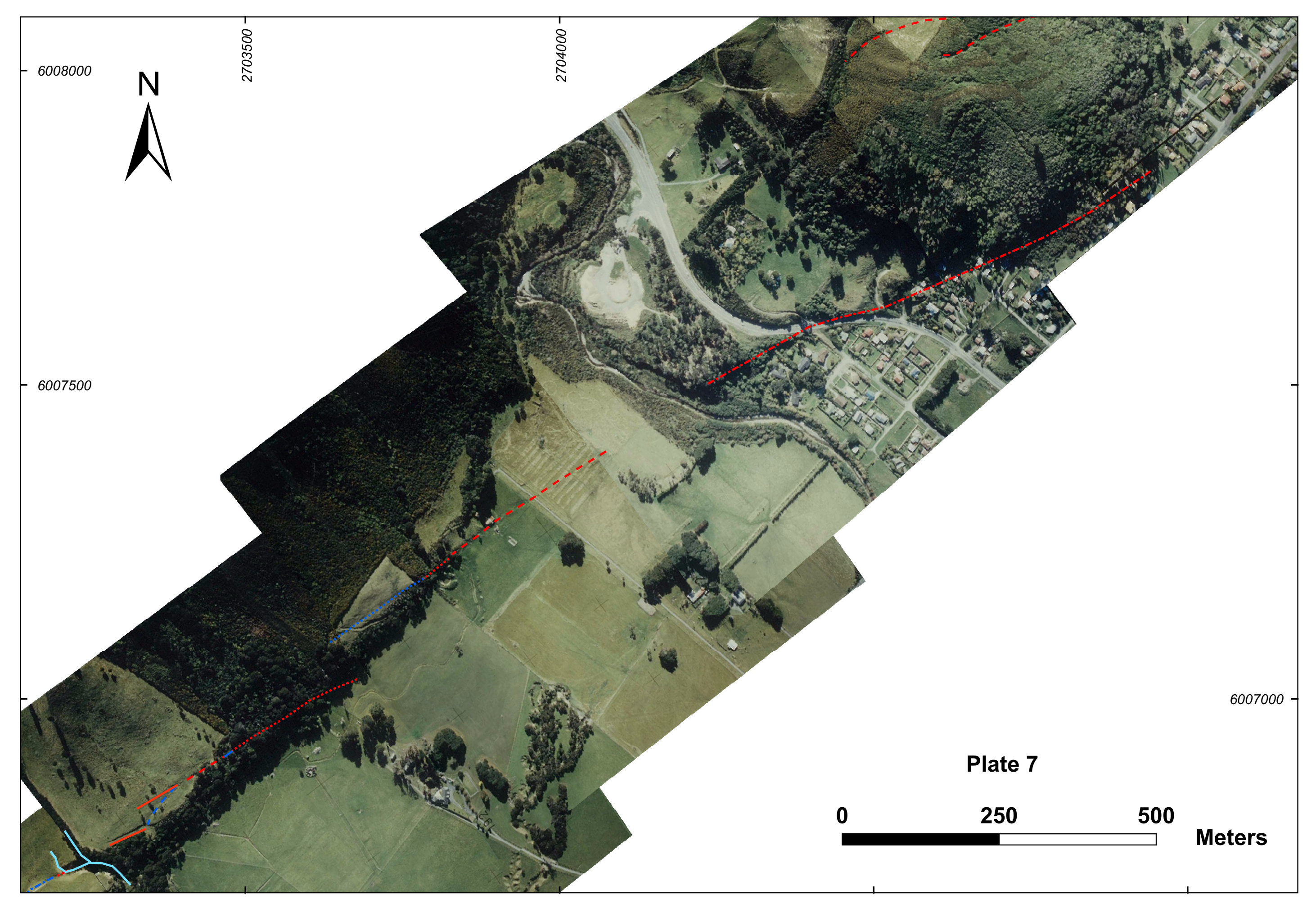




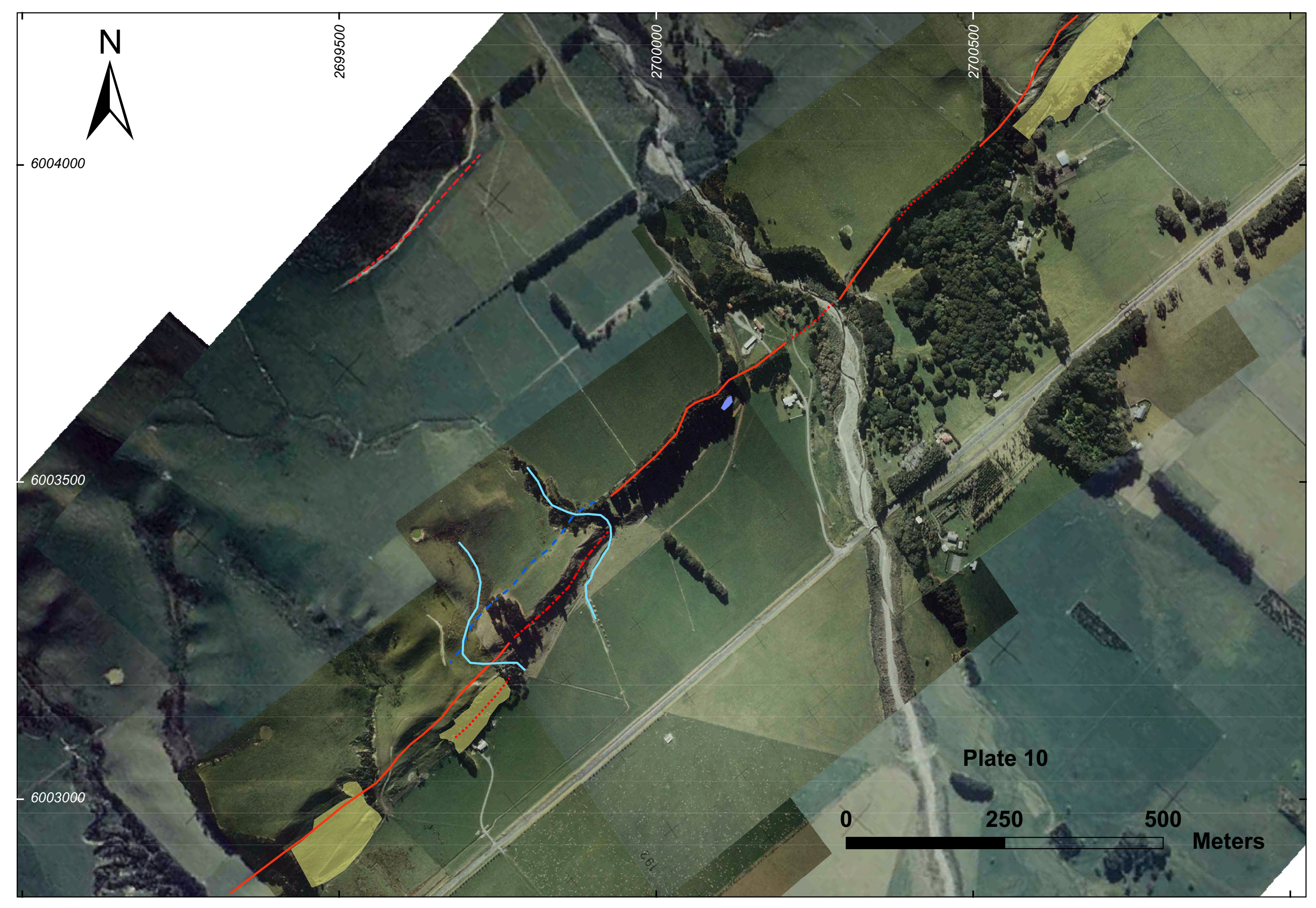




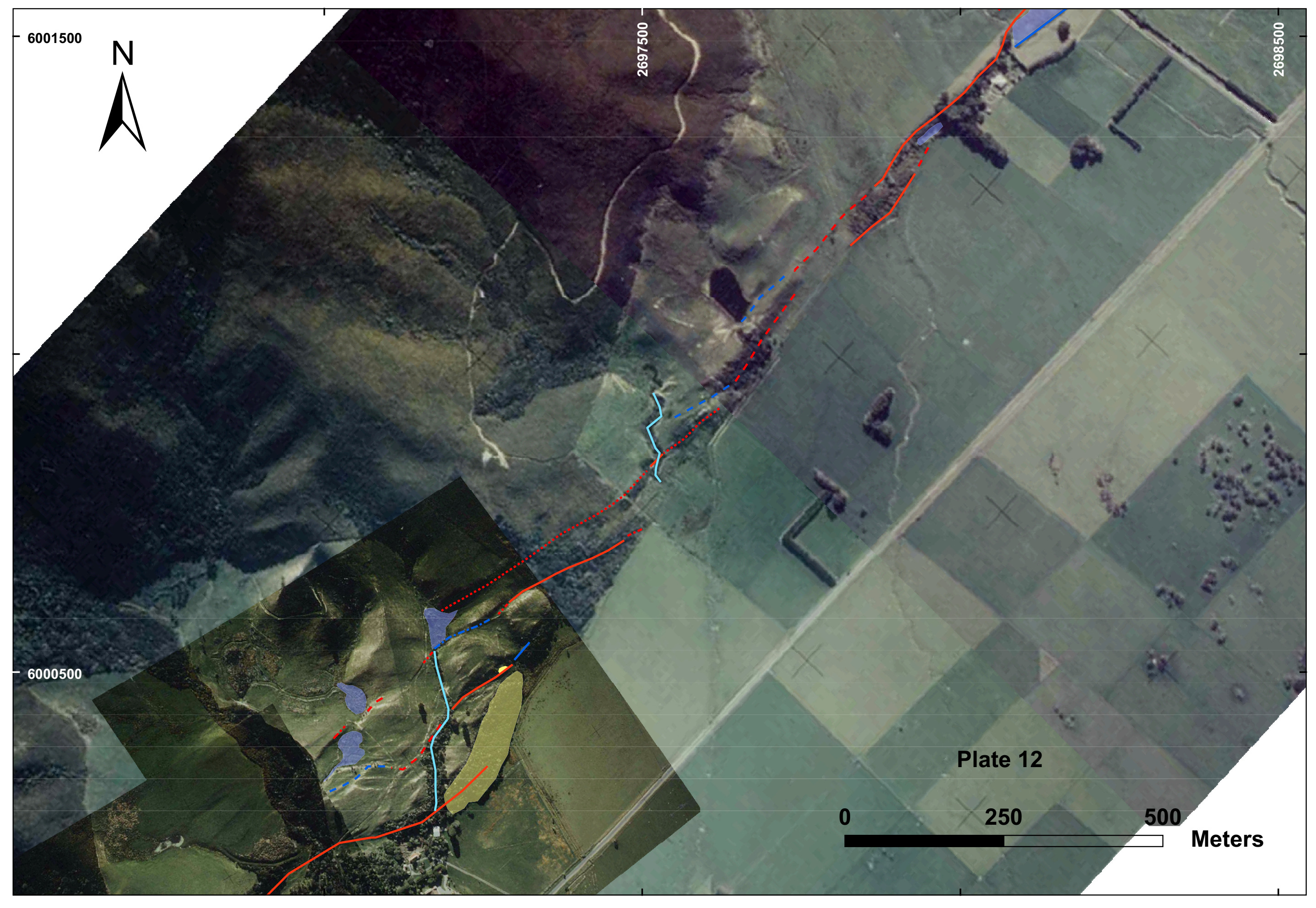

